January 2002

EVALUATION OF JUVENILE FALL

CHINOOK SALMON STRANDING ON THE

HANFORD REACH OF THE COLUMBIA RIVER

Annual Report 1999

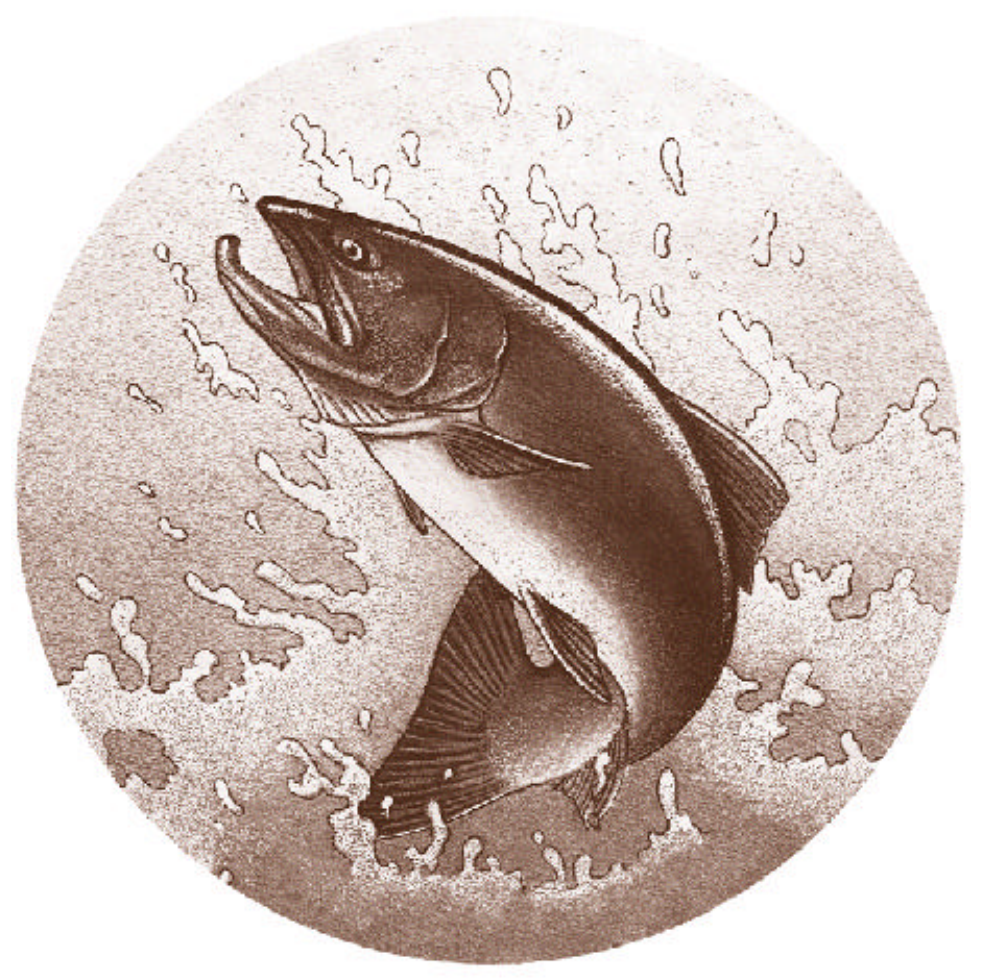

DOE/BP-00004294-1 
This report was funded by the Bonneville Power Administration (BPA), U.S. Department of Energy, as part of BPA's program to protect, mitigate, and enhance fish and wildlife affected by the development and operation of hydroelectric facilities on the Columbia River and its tributaries. The views of this report are the author's and do not necessarily represent the views of BPA.

This document should be cited as follows:

Nugent, John, Todd Newsome, Michael Nugent, Wendy Brock, Paul Wagner, Paul Hoffarth - Washington Department of Fish and Wildlife, 2002, 1999 Evaluation of Juvenile Fall Chinook Salmon Stranding on the Hanford Reach of the Columbia River, Report to Bonneville Power Administration, Contract No. 00004294, Project No. 199701400, 215 electronic pages (BPA Report DOE/BP-00004294-1)

This report and other BPA Fish and Wildlife Publications are available on the Internet at:

\section{http://www.efw.bpa.gov/cgi-bin/efw/FW/publications.cgi}

For other information on electronic documents or other printed media, contact or write to:

Bonneville Power Administration

Environment, Fish and Wildlife Division

P.O. Box 3621

905 N.E. 11th Avenue

Portland, OR 97208-3621

Please include title, author, and DOE/BP number in the request. 


\title{
1999 Evaluation of Juvenile Fall Chinook Salmon Stranding on the Hanford Reach of the Columbia River
}

\author{
Prepared for \\ The Bonneville Power Administration \\ The Public Utility District Number 2 of Grant County
}

\author{
John Nugent \\ Todd Newsome \\ Michael Nugent \\ Wendy Brock \\ Paul Wagner \\ Paul Hoffarth \\ Washington Department of Fish and Wildlife
}

January 24, 2002

BPA Contract Number 9701400

GCPUD Contracts Document 97BI30417 


\section{Executive Summary}

The Washington Department of Fish and Wildlife (WDFW) in cooperation with the Bonneville Power Administration (BPA), Grant County Public Utility District (GCPUD), Pacific Northwest National Laboratory (PNNL), University of Idaho (U of I), Streamside Programs Consultation (SPC), United States Geological Survey Biological Resources Division (USGS/BRD), and Yakama Nation (YN) performed the 1999 Evaluation of Juvenile Fall Chinook Salmon (Oncorhynchus tshawytscha) Stranding on the Hanford Reach of the Columbia River. The 1999 evaluation was the third year of a multi-year study to assess the impacts of water fluctuations from Priest Rapids Dam on rearing juvenile fall chinook salmon, other fish species, and benthic macroinvertebrates. The field effort was performed from March 5 through September 29.

The objectives of the 1999 evaluation were to collect basic information on the physical parameters of the Hanford Reach, evaluate the extent of stranding and entrapment of juvenile fall chinook salmon and other fish species, and identify critical habitat zones. The information will be used to develop a model for determining susceptibility of juvenile fall chinook salmon to stranding and entrapment due to flow fluctuations. WDFW subcontracted U of I and SPC to assess the effects of flow fluctuations on the benthic macroinvertebrate communities and USGS/BRD to study the effects of heat stress on the survival, predator avoidance ability, and physiology of juvenile fall chinook salmon.

River and meteorological conditions on the Hanford Reach during the 1999 juvenile fall chinook salmon emergence and rearing period (March-July) were marked by above average river flows, below normal ambient air temperatures, below normal precipitation, and above average solar radiation levels. Priest Rapids Dam (Rkm 639.1) discharges averaged $161.4 \mathrm{kcfs}$ from March 8 through June 30. Hourly discharge ranged from 61.9 to $261.3 \mathrm{kcfs}$. Mean daily fluctuation during this period was $42.1 \mathrm{kcfs}$.

Scanning Hydrographic Operational Airborne Lidar Survey (SHOALS) system bathymetry data collected by the United States Army Corps of Engineers (COE) in 1998 on $35.1 \mathrm{~km}^{2}$ of the Hanford Reach from Rkm 571.3 to Rkm 606.9 was processed in 1999. SHOALS data was used in conjunction with the Modular Aquatic Simulation System 1D (MASS1), a one-dimensional unsteady flow model for the Hanford Reach (Richmond and Perkins 1998), to characterize the Hanford Reach at stage discharges from 40-400 kcfs.

The Hanford Reach produced an estimated 8,405,936 fall chinook salmon fry in 1999. Juvenile fall chinook salmon were first captured in nearshore areas on March 5 and last sampled July 21. Peak abundance was observed between April 28 and June 2 with the largest catch of the season occurring on May 13. Juvenile fall chinook salmon with fork lengths at or below $42 \mathrm{~mm}$ (emergent fry) comprised $30 \%$ or more of the fish sampled each week through May 26. Fish with fork length greater than $59 \mathrm{~mm}$ (size threshold thought to be less susceptible to stranding or entrapment) began to appear in nearshore samples on May 5 but did not occur in large numbers until June 2.

Field crews located 1,026 stranded and entrapped juvenile fall chinook salmon in random plots in 1999. Fish were first encountered in random plots on March 20 and last observed June 12. The majority of stranded and entrapped fish were sampled during the weeks of March 21-27, April 4-10, April 11-17, and May 23-29. These time periods coincided with lower flows ( $<120 \mathrm{kcfs})$ and large flow fluctuations ( $>80 \mathrm{kcfs})$.

Stranded and entrapped juvenile fall chinook salmon had a mean fork length of $45.6 \mathrm{~mm}$ and ranged from 36 $\mathrm{mm}$ to $66 \mathrm{~mm}$. Individuals less than $60 \mathrm{~mm}$ comprised $96.9 \%$ of the juvenile fall chinook salmon measured. Fish were found throughout the SHOALS defined study area in a variety habitats and flow bands but the highest concentrations were found at the island complex areas of Locke Island (600-605 Rkm) and $100 \mathrm{~F}$ Islands (590$595 \mathrm{Rkm}$ ) at flows of 80-120 and 120-160 kcfs in random plots with gravel to cobble substrates, low substrate embeddedness, and absent to medium vegetation density.

The estimated total number of juvenile fall chinook salmon stranding and entrapment mortalities within the SHOALS defined study area (Rkm 571.3 to Rkm 606.9) in 1999 was calculated to be 125,695 with a $95 \%$ confidence interval between 50,724 and 200,666. Juvenile fall chinook salmon placed at risk of mortality due to stranding and entrapment was calculated to be 381,897 with a $95 \%$ confidence interval between -347 and 764,141 . 
Other fish species found stranded and entrapped in 1999 included northern pikeminnow (Ptychocheilus oregonensis), threespine stickleback (Gasterosteus aculeatus), smallmouth bass (Micropterus dolomieui), sculpin (Cottus spp.), mountain whitefish (Prosopium williamsoni), sucker (Catostomus spp.), bluegill (Lepomis macrochirus), lamprey (Lampetra spp.), peamouth (Mylocheilus caurinus), dace (Rhinichthys spp.), and walleye (Stizostedion vitreum). The stranding of lamprey in 1999 is of special interest because pacific lamprey (Lampetra tridentatus) and river lamprey (Lampetra ayresi) are listed as federal species of concern and river lamprey are also designated as a Washington State candidate species. Lampreys were also found stranded in 1998.

Long-and short-term studies of the effects of dewatering on artificial substrates, indicate water level fluctuations affect nearshore community structure, density, and biomass of macroinvertebrates in the Hanford Reach. Longterm tests on the effects of fluctuations clearly show that benthic macroinvertebrates within the river fluctuation zone were severely limited in density and biomass compared to the communities on continually inundated areas. Total invertebrate density was approximately 4 times higher on bricks never dewatered than on substrates exposed only 1 to 24 hours. Mean total invertebrate density and biomass were reduced by $59 \%$ and $65 \%$, respectively, from substrates exposed up to 24 hours to substrates never dewatered. Effects of short-term exposure scenarios revealed that a dramatic decrease in survival was found with even short duration exposures to air. Artificial exposure tests revealed that survival of macroinvertebrates on substrates exposed to air decreased dramatically with increasing duration of exposure, with only $50 \%$ survival after 1 hour of exposure. Changes in discharge and water levels also catastrophically entrained macroinvertebrates into the drift outside of behavioral diel periodicity.

USGS/BRD thermal tolerance tests showed thermally-stressed juvenile fall chinook salmon had little direct mortality and no increased vulnerability to predation. However, these fish showed transient increases in plasma concentrations of cortisol, glucose, and lactate, and a dramatic (25-fold higher than controls) and persistent (lasting 2 weeks) increase in levels of liver hsp70. It is not known what the consequences of exposure to multiple, cumulative stressors may be to the fish.

An emergency management team (EMT) consisting of WDFW and YN personnel was organized in 1999 to monitor primary fall chinook salmon rearing areas to identify flow fluctuation events that pose risks (imminent drainage of entrapments, lethal water temperatures) to large numbers of entrapped juvenile fall chinook salmon. The EMT monitored 119 entrapments from April 17 to June 21. A total of 8,240 juvenile fall chinook salmon were seined from these entrapments. Field crews recorded 166 direct mortalities at the time entrapments were sampled. Projected mortalities were estimated at 428 based on drainage or lethal temperatures monitored in entrapments. Criteria for emergency action were reached on four days (April 17, May 18, May 22, and May 23). GCPUD provided additional water to re-inundate (or increase river elevations) on each of these occurrences except May 22.

Based on the low estimated loss of juvenile fall chinook salmon in 1999, the Hanford Policy Group recommended, with the exception of eliminating the rewetting of entrapment zones after large fluctuations, that the operation constraints imposed in 1999 should be repeated in 2000. Operational constraints recommended for the 2000 juvenile fall chinook salmon emergence and rearing period include limiting flow fluctuations from Priest Rapids Dam to a range of $40 \mathrm{kcfs}$ on a daily basis $(60 \mathrm{kcfs}$ on a daily basis during flow augmentation for outmigrating juvenile fish under NMFS Biological Opinion) when weekly average flows are less than $170 \mathrm{kcfs}$ at Priest Rapids Dam and restricting flows to an hourly minimum of $150 \mathrm{kcfs}$ when weekly average flows are greater than $170 \mathrm{kcfs}$ at Priest Rapids Dam. 


\section{Table of Contents}

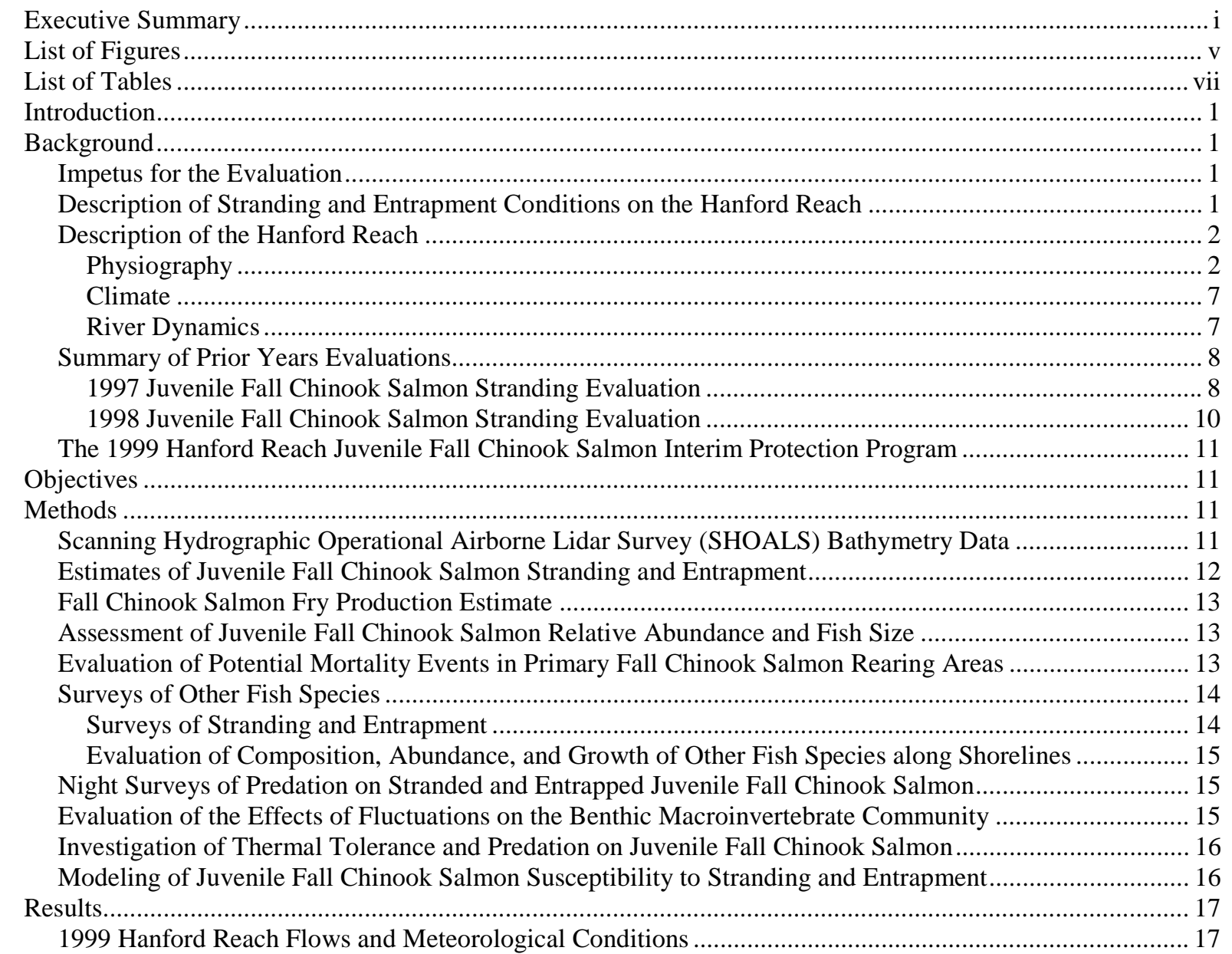

Implementation Timing and Operation of the 1999 Hanford Reach Juvenile Fall Chinook Salmon

Interim Protection Program............................................................................................................ 17

Scanning Hydrographic Operational Airborne Lidar Survey (SHOALS) Bathymetry Data ........................ 19

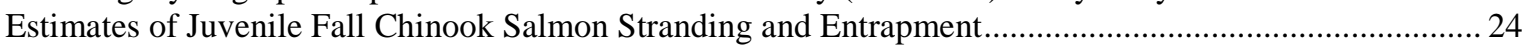

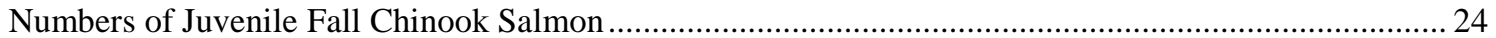

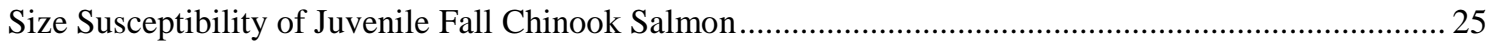

Distribution of Juvenile Fall Chinook Salmon ...................................................................... 25

Physical Characteristics of Random Sample Plots .................................................................. 26

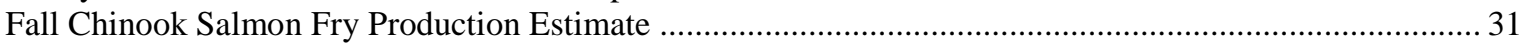

Assessment of Juvenile Fall Chinook Salmon Relative Abundance and Fork Length .............................. 31

Evaluation of Potential Mortality Events in Primary Fall Chinook Salmon Rearing Areas ......................... 32

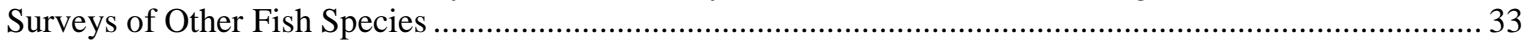

Spring and Early Summer................................................................................................... 33

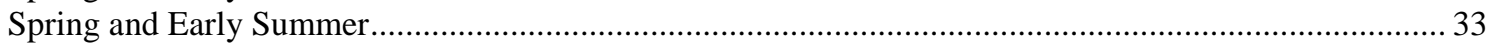

Night Surveys of Predation on Stranded and Entrapped Juvenile Fall Chinook Salmon.............................. 34

Evaluation of the Effects of Fluctuations on the Benthic Macroinvertebrate Community ........................... 34

Investigation of Thermal Tolerance and Predation on Juvenile Fall Chinook Salmon ................................ 35

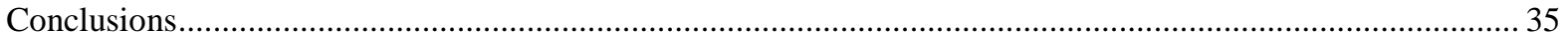

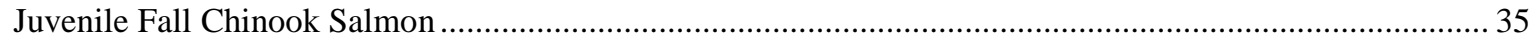

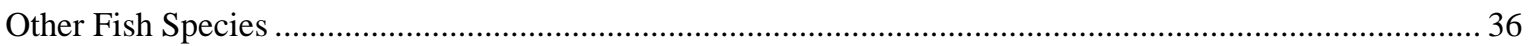

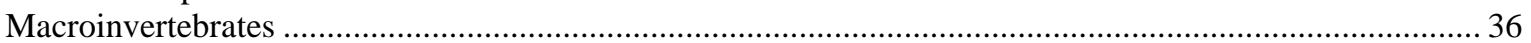

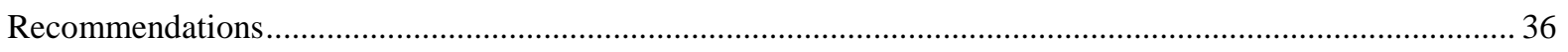

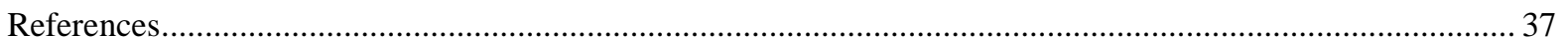


Appendix A: 1999 Hanford Reach Juvenile Fall Chinook Protection Program........................................... 40

Appendix B: Substrate Size, Substrate Embeddedness, and Vegetation Codes............................................47

Appendix C: Estimation of Total Number of Dead Chinook Caused by Stranding ....................................49

Appendix D: Data used in Hanford Reach Fall Chinook Salmon Fry Production Estimate ............................53

Appendix E: Effects of Water Level Fluctuations on Benthic Macroinvertebrates in the Hanford Reach,

Columbia River ....................................................................................................... 55

Appendix F: Effects of Semi-acute Thermal Stressors on the Survival, Predator Avoidance Ability, Stress

Physiology, and Heat Shock Protein Expression of Juvenile Fall Chinook Salmon 


\section{List of Figures}

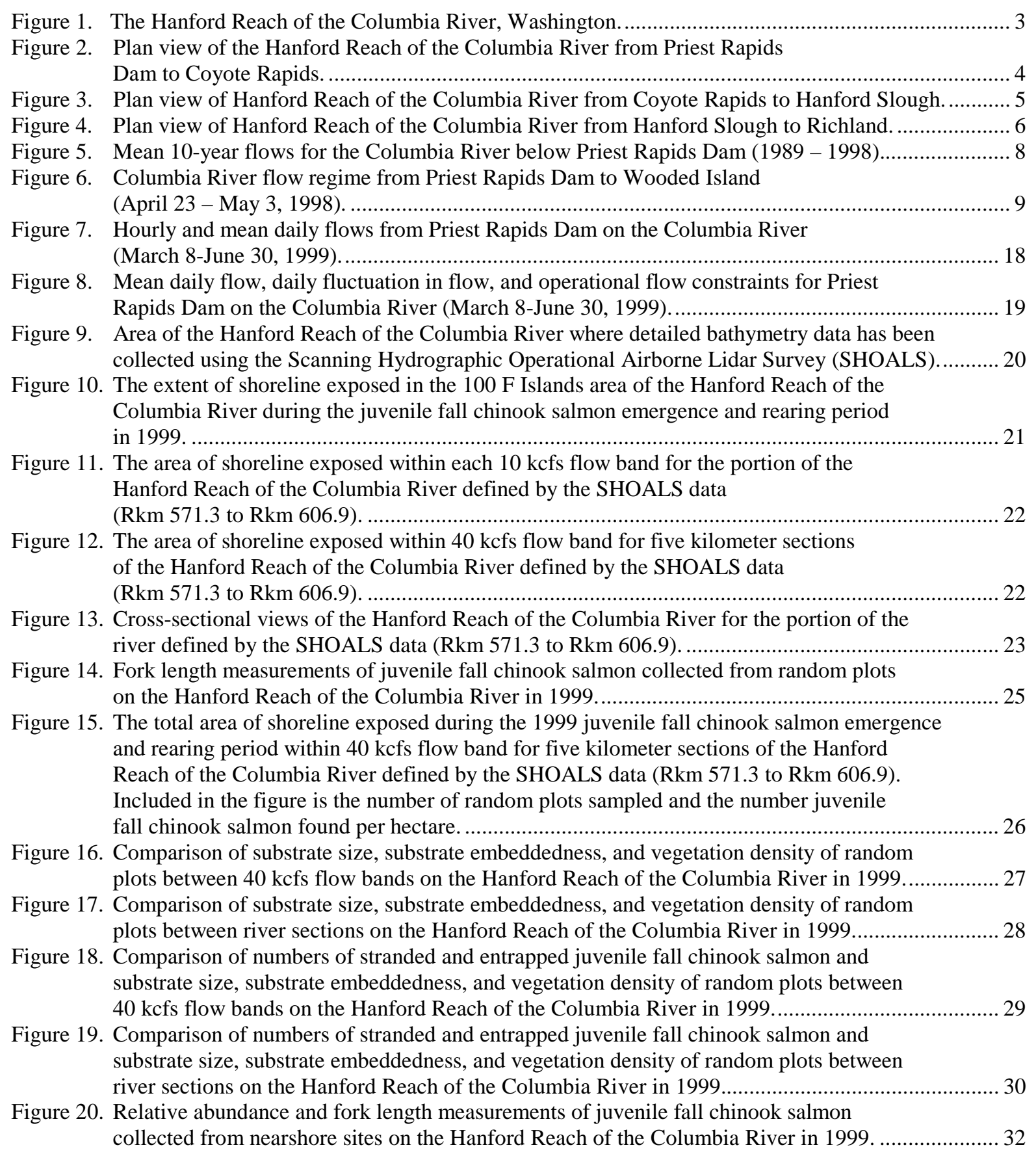




\section{List of Tables}

Table 1. Comparison of 1999 monthly average river flows, air temperatures, precipitation, and solar radiation levels to past years on the Hanford Reach of the Columbia River.

Table 2. Daily fluctuations in flow from Priest Rapids Dam on the Columbia River (March 8-June 30, 1999).

Table 3. Weekly numbers of juvenile fall chinook salmon found in random plots on the Hanford

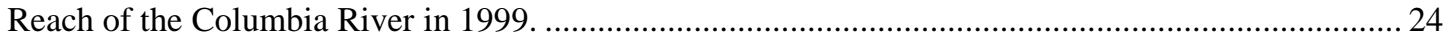

Table 4. Calculation of the 1999 fall chinook salmon fry production estimate for the Hanford Reach

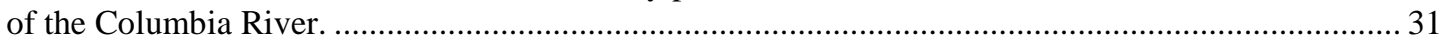

Table 5. Weekly numbers of juvenile fall chinook salmon found by emergency management teams in

primary rearing areas on the Hanford Reach of the Columbia River in 1999. ............................... 32

Table 6. Total number of fish other than fall chinook salmon sampled on the Hanford Reach of the Columbia River during the spring and early summer sampling period (March 19-June 30, 1999)...... 33

Table 7. Total number of fish sampled on the Hanford Reach of the Columbia River during the summer and early fall sampling period (July1-September 29, 1999). 


\section{Introduction}

The Washington Department of Fish and Wildlife (WDFW) has been contracted through the Bonneville Power Administration (BPA) and the Grant County Public Utility District (GCPUD) to perform an evaluation of juvenile fall chinook salmon (Oncorhynchus tshawytscha) stranding on the Hanford Reach. The evaluation, in the third year of a multi-year study, has been developed to assess the impacts of water fluctuations from Priest Rapids Dam on rearing juvenile fall chinook salmon, other fishes, and benthic macroinvertebrates of the Hanford Reach. This document provides the results of the 1999 field season.

\section{Background}

The background section for this document includes: the impetus for the evaluation, a description of the environmental conditions that exist on the Hanford Reach, a summary of the 1997 and 1998 reports, and an outline of the 1999 Interim Protection Program for Hanford Reach juvenile fall chinook salmon.

\section{Impetus for the Evaluation}

The BPA has been directed by the National Marine Fisheries Service (NMFS) under the Endangered Species Act - Section 7 - Biological Opinion on the Reinitiating of Consultation on 1994-1998 Operation of The Federal Columbia River Power System and Juvenile Transportation Program to perform the following:

"Beginning in 1995, BPA will evaluate the affect of power peaking operations on juvenile and adult salmon passage and on the river ecology downstream of Bonneville Dam and on the Hanford Reach, downstream of Priest Rapids Dam. Contingent on the results of these evaluations BPA will develop a plan to decrease power peaking operations from mid-March through mid-December on the lower Snake and Columbia Rivers (page 162,\#11)".

In addition, as an objective of the 1994 Columbia River Basin Fish and Wildlife Program, BPA has been directed to perform the following:

"Beginning in 1995, evaluate alternative ramping rates for flow fluctuations at mainstem Snake and Columbia River dams to constrain reductions and increases in total flow per 24-hour period at these projects (Page 5-20, 5.1D.4)".

This evaluation of juvenile fall chinook salmon stranding on the Hanford Reach is consistent with both of these objectives.

\section{Description of Stranding and Entrapment Conditions on the Hanford Reach}

The Hanford Reach supports the larger of the only two remaining healthy naturally spawning fall chinook salmon populations in the Columbia River System (Huntington et al.1996). This population is a primary source of ocean and freshwater sport, commercial, and in-river tribal fisheries (Dauble and Watson 1997), and is a primary component of the Pacific Salmon Treaty between the United States and Canada. River flows for this section of the Columbia River are manipulated by discharge from Priest Rapids Dam. Flow fluctuations from Priest Rapids Dam occur rapidly due to changes in hydroelectric power generation (power peaking), irrigation, water storage, and flood control. These fluctuations have been observed to cause stranding and entrapment of juvenile fall chinook salmon on gently sloped banks, gravel bars and in pothole depressions on the Hanford Reach (Page 1976, Becker et al. 1981, DeVore 1988, Geist 1989, Wagner 1995, Ocker 1996, Wagner et al. 1999, Nugent et al. 2001).

Stranding of juvenile fall chinook salmon occurs when the fish are trapped on or beneath the unwatered substrate as the river level recedes. Entrapment occurs when the fish are separated from the main river channel in depressions as the river level recedes. Entrapped fish may become stranded when depressions drain completely. Fish mortality occurs from stranding, warming of water in entrapments (thermal stress), and by piscivorous and avian predation in small shallow entrapments. 
The impact of river fluctuations due to operation of hydroelectric facilities on rearing salmonids has been assessed on numerous Columbia River tributaries and other river systems (Thompson 1970, Witty and Thompson 1974, Phinney 1974a and 1974b, Bauersfeld 1978, Tipping et al. 1978 and 1979, Becker et al. 1981, Woodin 1984, and Beck 1989) but limited research has been conducted on the Hanford Reach (Page 1976, Becker et al. 1981). The 1999 evaluation has been performed to estimate the loss of juvenile fall chinook salmon on the Hanford Reach to stranding and entrapment and for directing the future management of flows from Priest Rapids Dam.

\section{Description of the Hanford Reach}

The Hanford Reach stretches from Priest Rapids Dam 82 km downstream to Richland, Washington. The physiography, river dynamics, and climate of the area create a unique habitat for wildlife and fish populations.

\section{Physiography}

Lands along the Hanford Reach are owned and/or managed by the United States Department of Energy (DOE) Hanford Site, the United States Fish and Wildlife Service (USFWS) Saddle Mountain National Wildlife Refuge, and the WDFW Waluke Wildlife Management Area (Figure 1). In 1943, the United States Atomic Energy Commission requisitioned these lands surrounding the Hanford Reach for the siting of facilities to produce plutonium for the first atomic weapons. Due to the secure nature of the facilities, the Hanford Reach and the surrounding lands have remained protected and only limited development has occurred in small intensely disturbed areas adjacent to the facilities. The undeveloped areas contain one of the largest remnant sections of shrub-steppe ecosystem in the Columbia River Basin.

For descriptive purposes, the Hanford Reach can be broken down into five distinct river sections. These sections are Priest Rapids Dam (Rkm 639.1) to Coyote Rapids (Rkm 615.6), from Coyote Rapids to the beginning of the White Bluffs (Rkm 605.1), from the beginning of the White Bluffs to Hanford Slough (Rkm 582.6), Hanford Slough to Savage Island (Rkm 572.9), and from Savage Island to the McNary Pool (Rkm 545.6) in Richland. Detailed plan views of the Hanford Reach are provided in Figures 2, 3, and 4.

The first segment of river from Priest Rapids Dam to Coyote Rapids flows to the east. This section of river consists of a series of gentle meanders. The meanders are characterized by cutbanks on the outside of the meanders and point bars on the inside downstream portion of the meanders. The cutbanks in this section are typified by steep embankments or to a lesser extent rock walls. The cutbank from Rkm 637.3 to Rkm 632.4 is an outcropping of basalt associated with the terminus of Umtanum Ridge. Gentle embankments, flats and downstream gravel bars distinguish the point bars in this section. Notable downstream gravel bars critical to fall chinook salmon spawning are Vernita Bar (Rkm 632.4) and a gravel bar immediately upstream of Coyote Rapids at (Rkm 616.4).

At Coyote Rapids the river turns and flows to the northeast. The next section of river from Coyote Rapids to the beginning of the White Bluffs is straight and channelized with relatively steep embankments. Some fall chinook salmon spawning occurs at the top of the island at Rkm 606.7.

At the beginning of the White Bluffs, the river makes an abrupt turn to the southeast. Unconsolidated bluffs on the northeast bank and island complexes dominate this next section of river from the beginning of the White Bluffs to the bottom of Hanford Slough. The river becomes braided through this segment and the bluffs rise to greater than $150 \mathrm{~m}$ above the surface of the river. The island complexes with associated islands, gravel bars and backwater sloughs provide extensive critical spawning and rearing habitat for fall chinook salmon.

Below Hanford Slough the river continues to flow to the southeast to the bottom of Savage Island. This section of the river from the bottom of Hanford Slough to the bottom of Savage Island is straight and channelized with relatively steep embankments. No observed fall chinook salmon spawning occurs in this section of the river. 


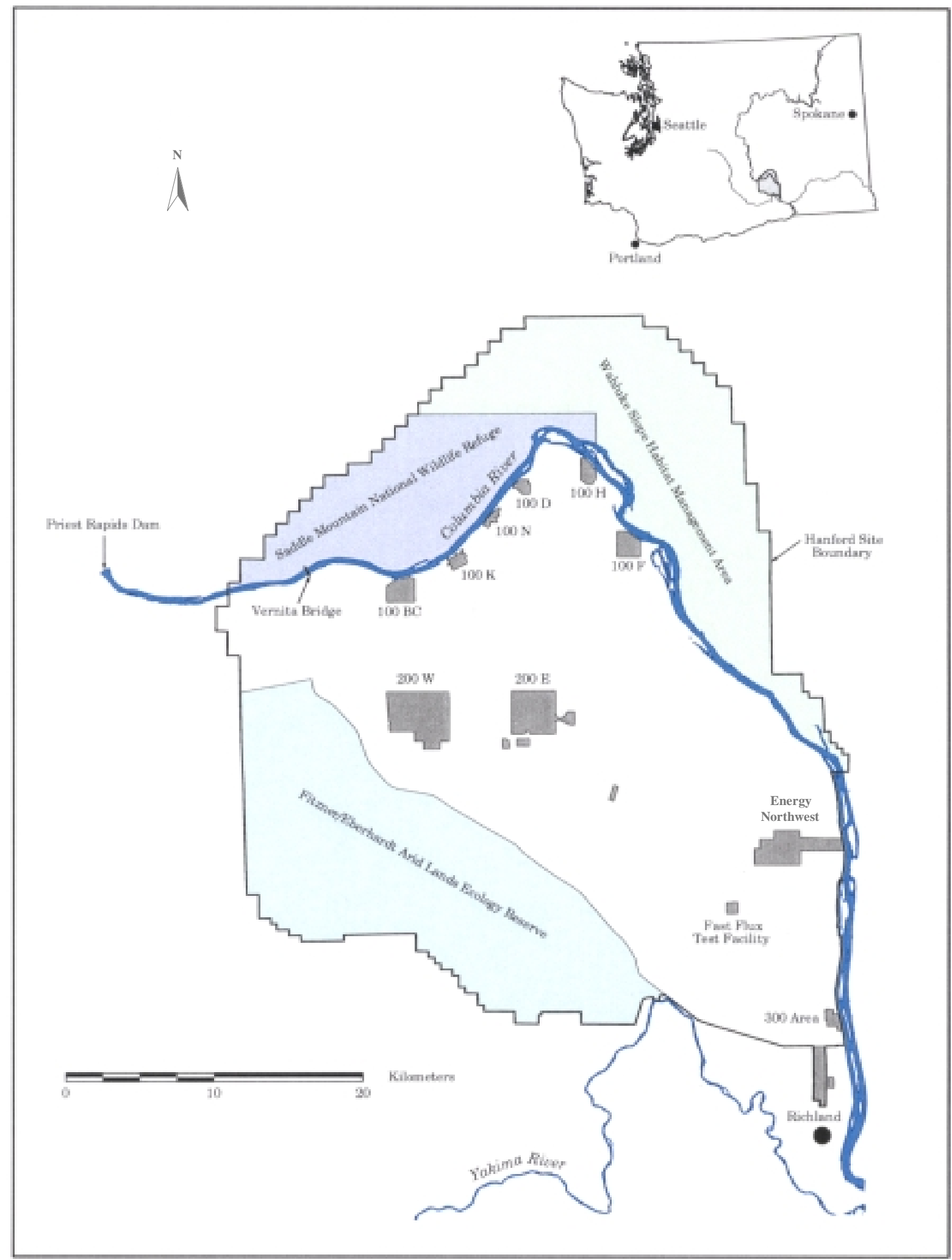

Figure 1. The Hanford Reach of the Columbia River, Washington. 


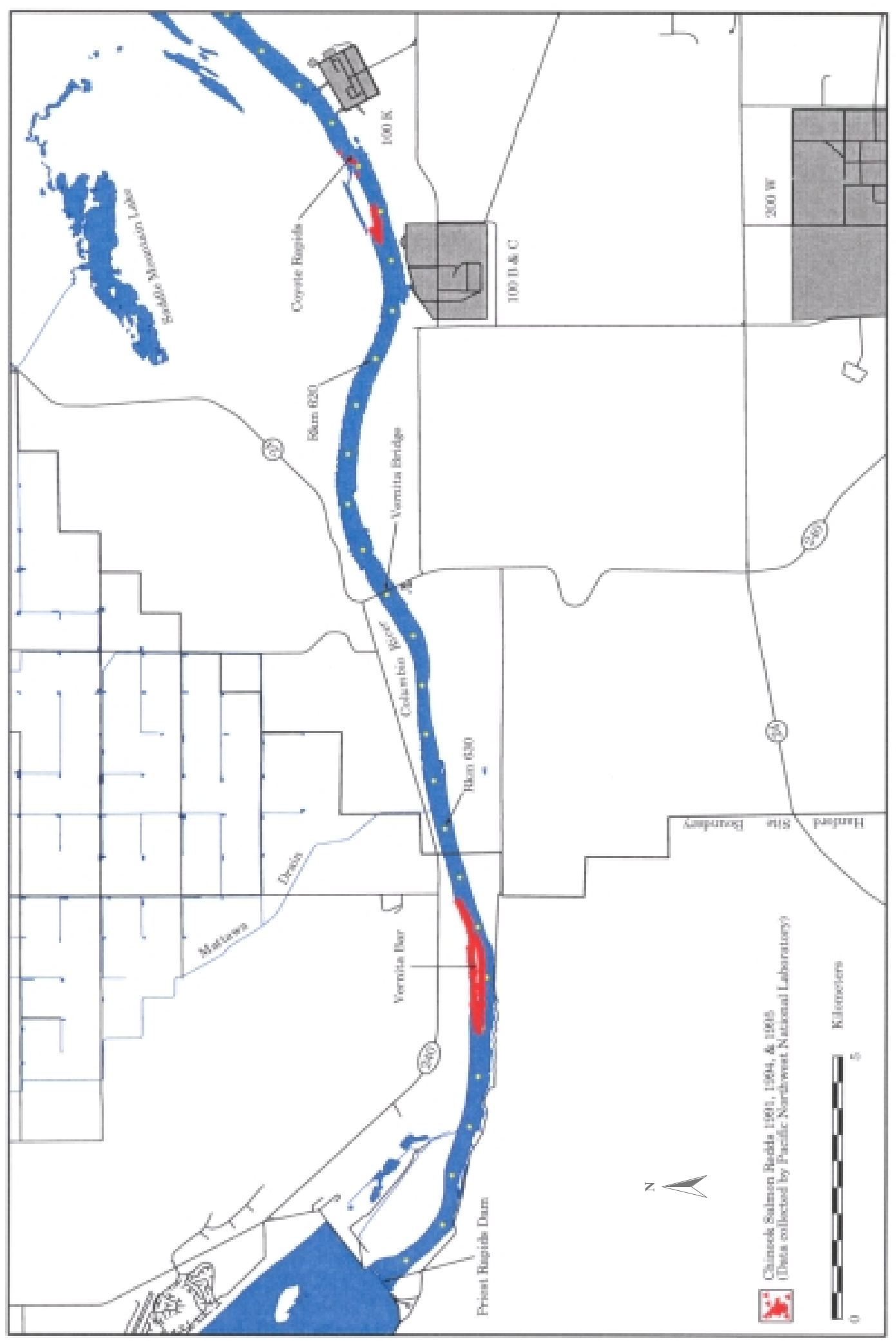

Figure 2. Plan view of the Hanford Reach of the Columbia River from Priest Rapids Dam to Coyote Rapids. 


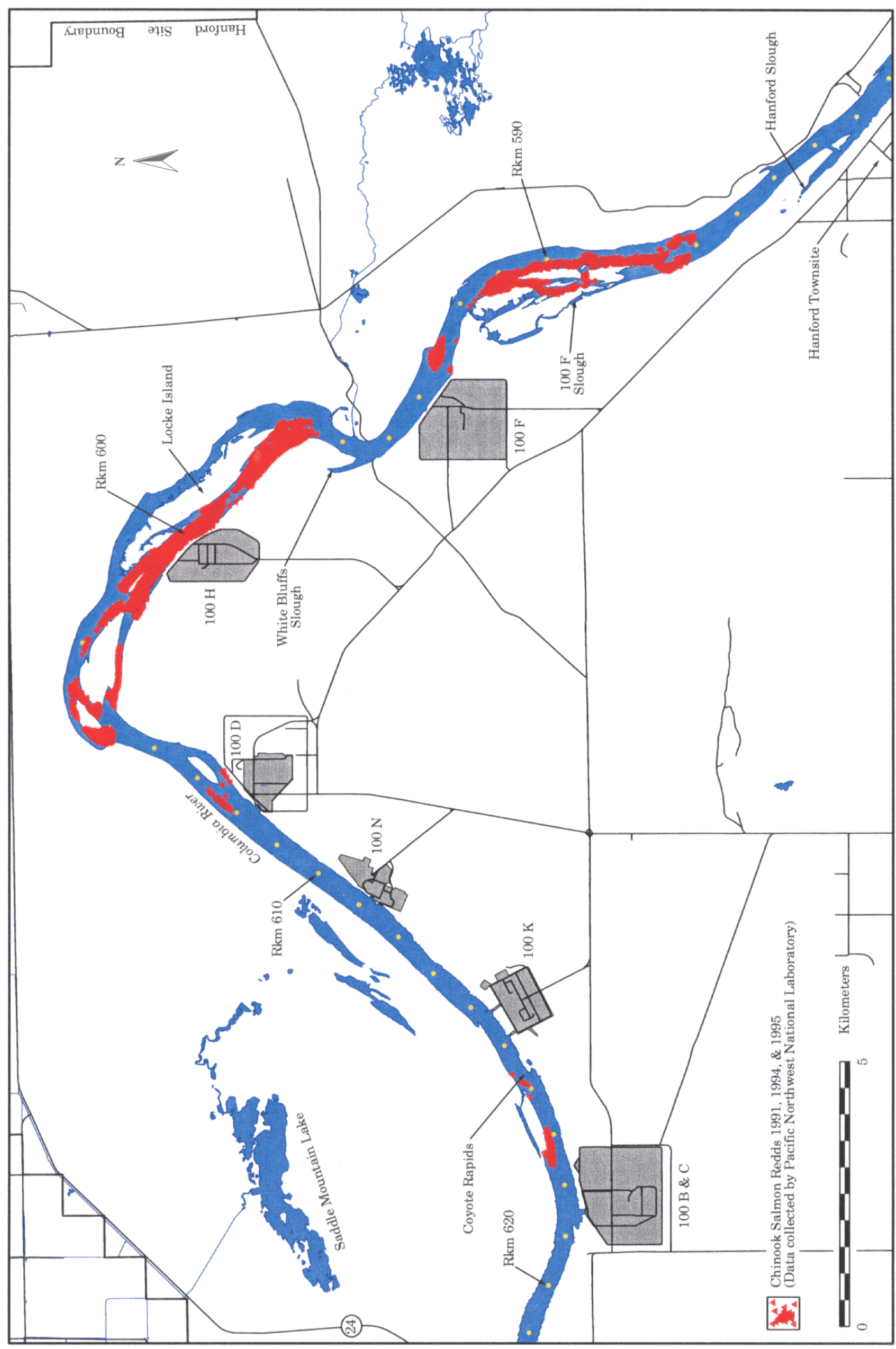

Figure 3. Plan view of Hanford Reach of the Columbia River from Coyote Rapids to Hanford Slough. 


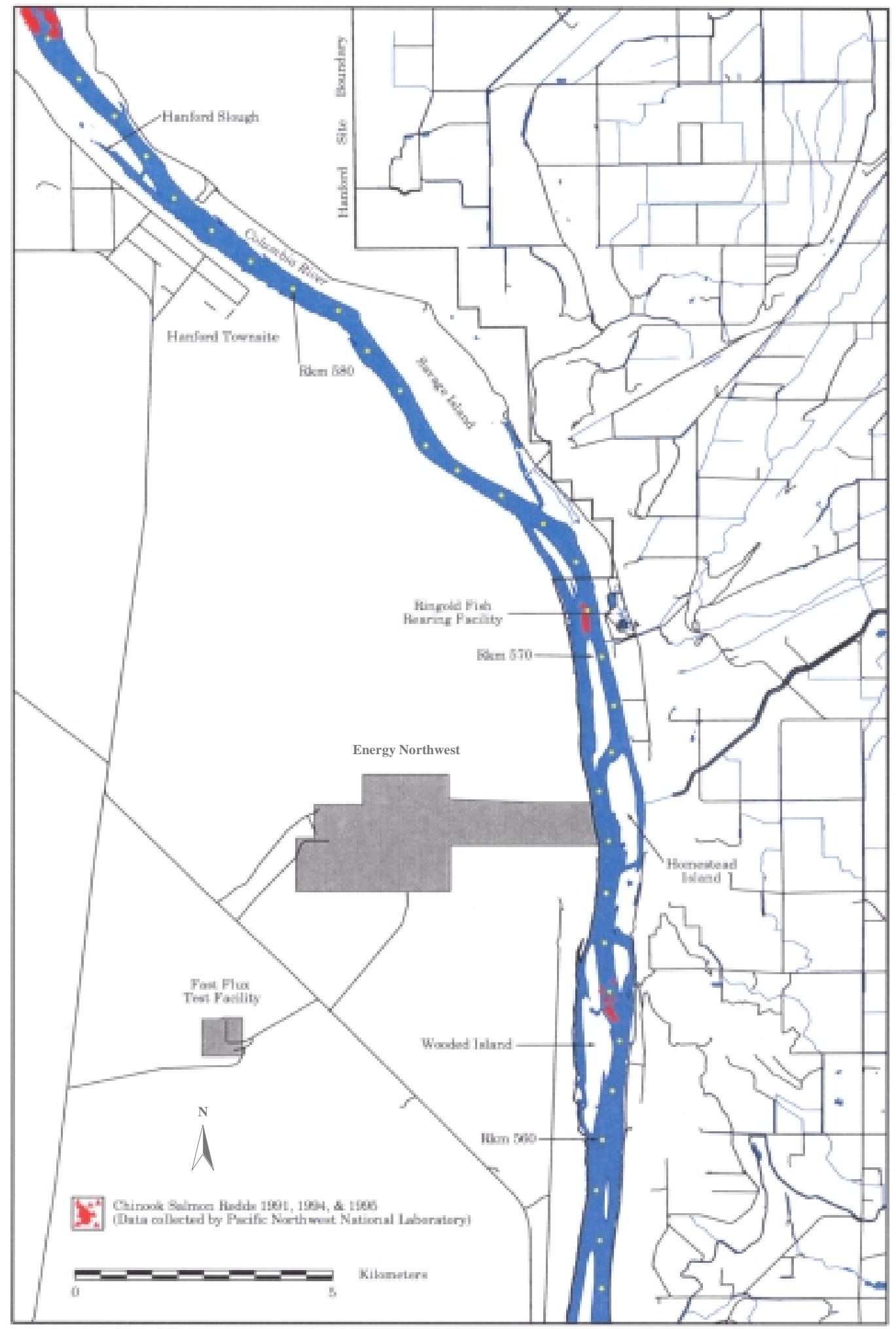

Figure 4. Plan view of Hanford Reach of the Columbia River from Hanford Slough to Richland. 
Below Savage Island the river turns to the south. Unconsolidated bluffs on the eastern bank and sand dunes and steep embankments on the western bank dominate this final section of the Hanford Reach, from the bottom of Savage Island to the top of the McNary Pool in Richland. The river channel is incised and straight and island formation appears restricted by the river channel. Braiding is less pronounced than in upper stretches of the river providing less gravel bar and backwater areas. Fall chinook salmon spawning occurs at the top of the main channel island adjacent to the Ringold fish hatchery (Rkm 570.5) and near Wooded Island (Rkm 561.6).

\section{Climate}

The Hanford Reach, situated in the rain shadow of the Cascade Mountain Range, receives an annual mean precipitation of $16.1 \mathrm{~cm}$ and is considered mid-latitude semi arid (Glantz et al. 1990). Most of the precipitation falls between October and May (Rickard 1988). Summers are warm and dry with temperatures often exceeding $38^{\circ} \mathrm{C}$ (Glantz et al.1990). Winters are cool with occasional precipitation and outbreaks of cold artic air that can drop temperatures below $-18^{\circ} \mathrm{C}$ (Glantz et al.1990).

During the juvenile fall chinook salmon emergence and rearing period (March - June) average maximum temperatures range from $14.1^{\circ} \mathrm{C}$ in March to $28.8^{\circ} \mathrm{C}$ in June. Average minimum temperatures range from $1.1^{\circ} \mathrm{C}$ in March to $12.9^{\circ} \mathrm{C}$ in June. Precipitation averages $4.5 \mathrm{~cm}$ during the juvenile fall chinook salmon emergence and rearing period. Large diurnal temperature contrasts can occur during this time period due to low relative humidity in combination with intense solar radiation during the day and radiational cooling at night (Hanford Meteorological Station, PNNL 1998).

\section{River Dynamics}

The Hanford Reach is the only un-impounded and last free flowing section of the Columbia River above Bonneville Dam. Priest Rapids Dam, built in 1959, regulates flow discharges and is the major influence of river dynamics on the Hanford Reach.

Daily fluctuations in river elevation on the Hanford Reach are the result of discharge changes from Priest Rapids Dam and can vary significantly on an hourly basis. Historically, under normal project operations, tailwater reductions in excess of $7 \mathrm{vertical} \mathrm{ft} / \mathrm{hr}(2.1 \mathrm{~m} / \mathrm{hr})$ and 13 vertical $\mathrm{ft}(4.0 \mathrm{~m})$ within a $24-\mathrm{hr}$ period have occurred during the juvenile fall chinook salmon emergence and rearing period.

Seasonal daily average discharges from Priest Rapids Dam range from about 40 to $250 \mathrm{kcfs}$ (Dauble and Watson 1997). Average seasonal flows from 1989 to 1998 show that spring runoff peaks during mid-June and decreases significantly during the summer with annual minimum flows in September (Figure 5). The Federal Energy Commission has established $36 \mathrm{kcfs}$ as a minimum flow from Priest Rapids Dam (Dauble and Watson 1997).

Fluctuations in river elevation downstream of Priest Rapids Dam are dampened by channel configuration and bank storage. Translation time of fluctuations downstream is determined by a variety of factors that may include river configuration, bank storage, and magnitude and duration of the fluctuation. Figure 6 illustrates the entire flow regime from below Priest Rapids Dam (Rkm 639.0) to the bottom of Wooded Island (Rkm 560.6) over a one-week period during the 1998 juvenile fall chinook salmon emergence and rearing period. Corresponding stranding and entrapment events that occurred during this time period and the number of juvenile fall chinook salmon associated with each event also are represented.

The Hanford Reach has no natural tributaries and receives little additional influent from other sources. Other minimal sources of influent include irrigation runoff and groundwater discharge. 


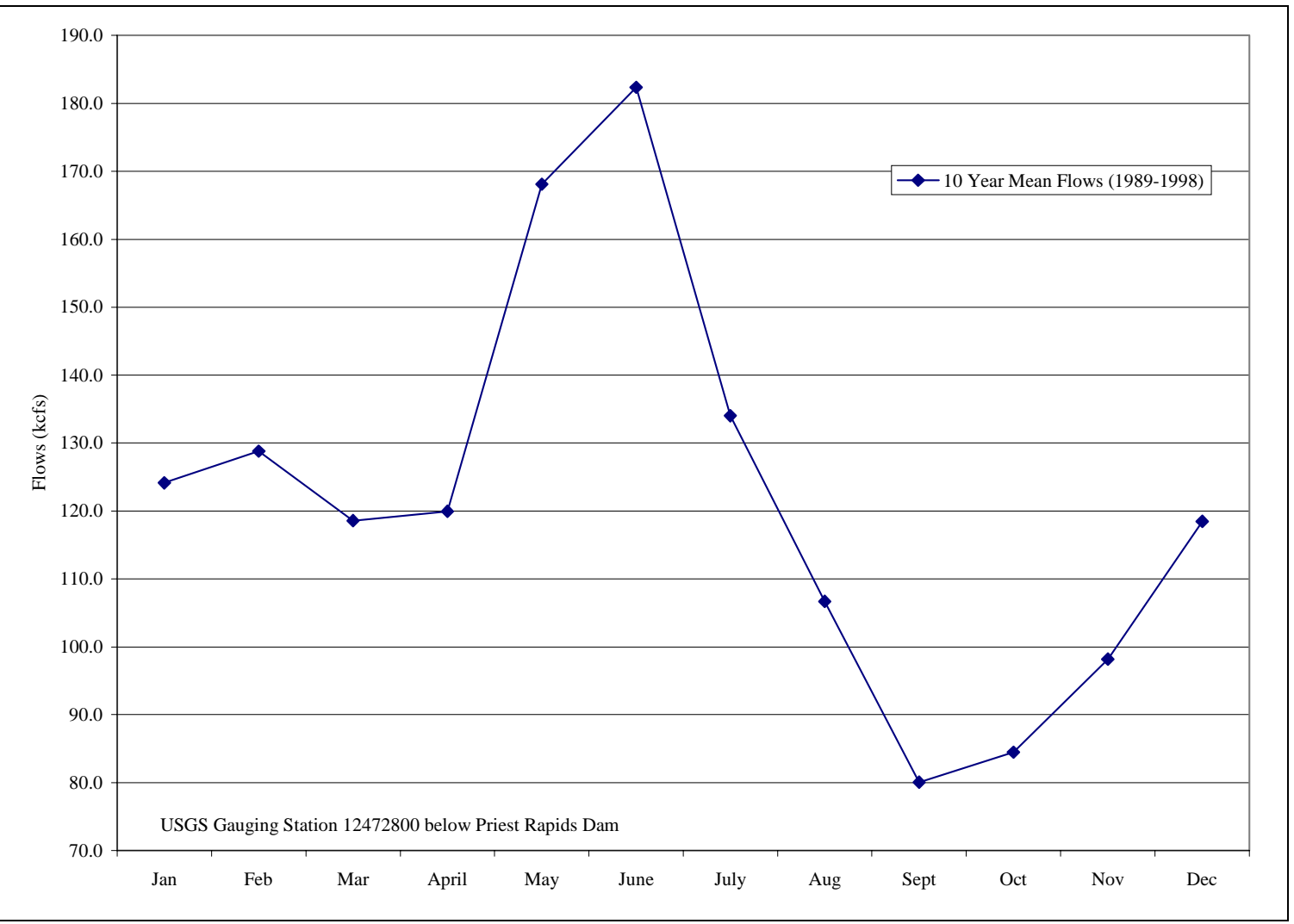

Figure 5. Mean 10-year flows for the Columbia River below Priest Rapids Dam (1989 - 1998).

\section{Summary of Prior Years Evaluations}

\section{Juvenile Fall Chinook Salmon Stranding Evaluation}

In 1997, WDFW performed pilot fieldwork from May 7 through July 28. The work was performed to aid in the development of a work plan for the 1998 evaluation of juvenile fall chinook salmon stranding on the Hanford Reach.

The Hanford Reach was exposed to exceptionally high river flows in 1997. For example, annual flows in 1997 averaged $169 \mathrm{kcfs}$ compared to only $114 \mathrm{kcfs}$ (range $91-161 \mathrm{kcfs})$ during the previous ten years $(1987-1996)$. In addition, June flows in 1997 averaged $323 \mathrm{kcfs}$ compared to $156 \mathrm{kcfs}$ (range $111-237 \mathrm{kcfs}$ ) for the previous ten years.

High spring river flows in 1997 hampered field activities. Field operations that could not be completed included two controlled river elevation reduction tests and the assessment of stranding in cobble substrate. Investigation work completed included the identification of the primary juvenile fall chinook salmon production areas and the determined feasibility of a benthic macroinvertebrate evaluation. In addition, Pacific Northwest National Laboratory (PNNL) completed work on the Modular Aquatic Simulation System 1D (MASS1), a onedimensional unsteady flow model for the Hanford Reach (Richmond and Perkins 1998).

Results of the field investigations indicated that despite the high flow year, juvenile fall chinook salmon as well as other fishes were observed stranded and entrapped. Other fishes found stranded and entrapped included sucker (Catostomus spp.), northern pikeminnow (Ptychocheilus oregonensis), redside shiner (Richardsonius balteatus), peamouth (Mylocheilus caurinus), smallmouth bass (Micropterus dolomieui), threespine stickleback (Gasterosteus aculeatus), sculpin (Cottus spp.), common carp (Cyprinus carpio), and largemouth bass (Micropterus salmoides). 

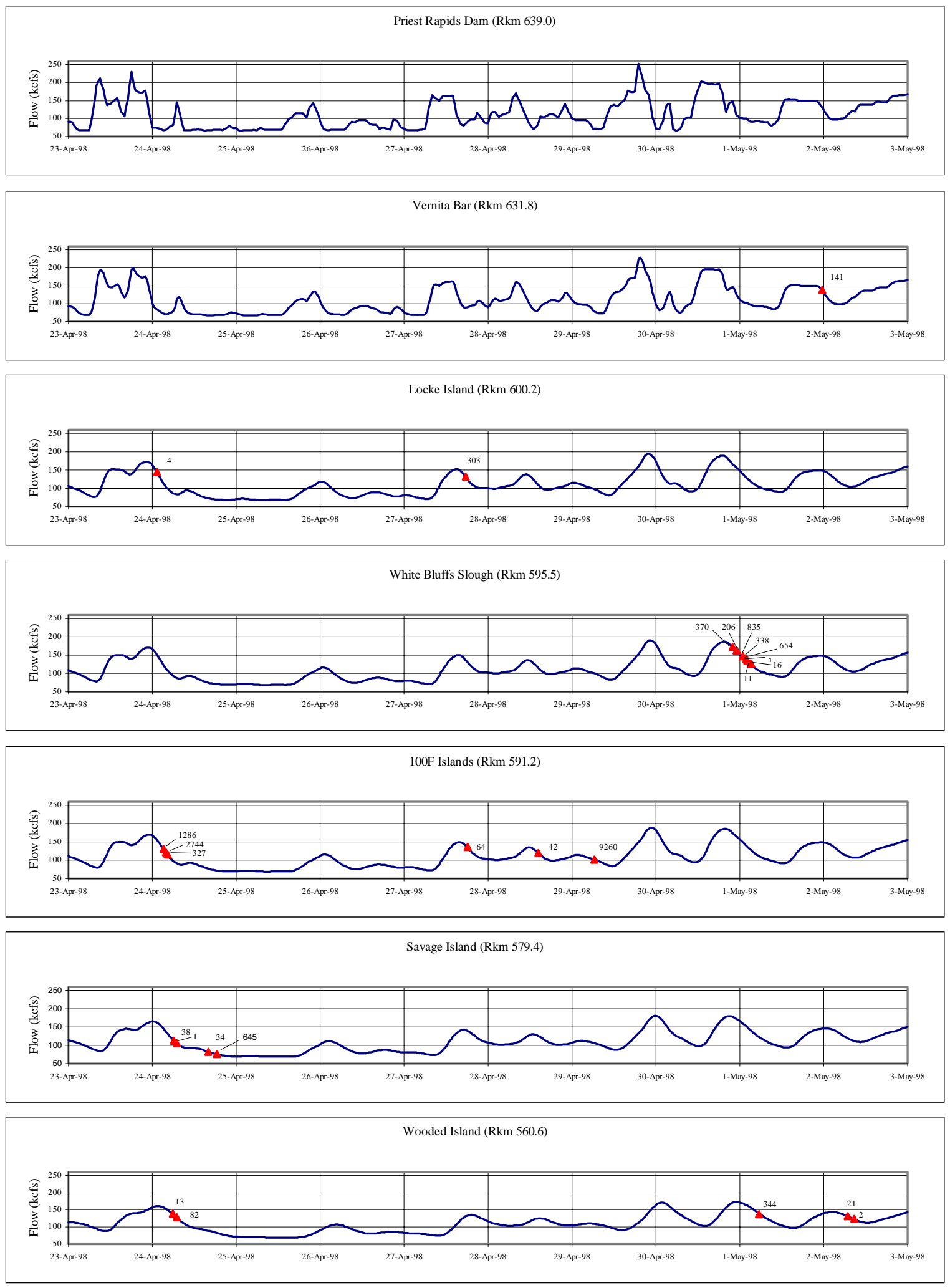

- Stranding or Entrapment Event (number indicates stranded or entrapped juvenile fall chinook salmon)

Figure 6. Columbia River flow regime from Priest Rapids Dam to Wooded Island (April 23 - May 3, 1998). 
Field observations indicated stranding and entrapment susceptibility of juvenile fall chinook salmon appeared to decrease with increasing fish size. A size threshold of $81 \mathrm{~mm}$ was identified as the end of juvenile fall chinook salmon stranding and entrapment susceptibility. Thermal stress and thermal shock appeared to be the primary sources of juvenile fall chinook salmon mortality in entrapment areas. Juvenile fall chinook salmon and other fishes demonstrated evidence of specific habitat preference and appeared to be somewhat segregated. Some species of fish appeared to be more susceptible as spawning adults while others were most susceptible as newly hatched fry.

\section{Juvenile Fall Chinook Salmon Stranding Evaluation}

The 1998 field efforts were performed from March 12 through October 5. These efforts were mainly exploratory because high flows hampered the 1997 pilot year evaluation. The objectives of the 1998 evaluation were to collect basic information on the physical parameters of the Hanford Reach, evaluate the extent of stranding and entrapment of juvenile fall chinook salmon and other fishes, and identify critical habitat zones. The data collected was used to generate a sampling design for 1999. The information is also being used in the development of a model to determine susceptibility of juvenile fall chinook salmon to stranding and entrapment due to river elevation fluctuations. WDFW subcontracted the University if Idaho (U of I) and Streamside Programs Consultation (SPC) to assess the effects of river fluctuations on the benthic macroinvertebrate communities and the United States Geological Survey Biological Resources Division (USGS/BRD) to study the effects of heat stress on the survival, predator avoidance ability, and physiology of juvenile fall chinook salmon. The United States Army Corps of Engineers (COE) also was subcontracted to collect detailed bathymetry data on the Hanford Reach using the Scanning Hydrographic Operational Airborne Lidar Survey (SHOALS) system.

River conditions on the Hanford Reach in 1998 were marked by below average river flows, above normal ambient air temperatures, near normal precipitation, and near average solar radiation levels.

Juvenile fall chinook salmon first appeared in both nearshore and entrapment sites on March 19 and were last encountered in entrapments on June 24 and last sampled in nearshore sites on June 27. Peak numbers of individuals and mortalities were observed between early April and early May. Juvenile fall chinook salmon distribution and mortality was highest at island complex areas. Individuals less than $59 \mathrm{~mm}$ in length were most susceptible to entrapment. Juvenile fall chinook salmon appeared to be most vulnerable to reductions in flow at night, in the first $0.9 \mathrm{~m}$ of vertical flow reduction, and when reductions occurred between $100 \mathrm{kcfs}$ and 140 kcfs. Juvenile fall chinook salmon were found to be stranded/entrapped by the smallest flow reductions measurable. The majority of stranding mortalities (94.4\%) occurred within 24 hours of the entrapment creation time while most thermal mortalities $(99.8 \%)$ took place within three days. Stranding mortality occurred more often over coarse unembedded substrates while thermal mortality took place more frequently over fine embedded substrates. Juvenile fall chinook salmon were found most regularly in areas absent of vegetation.

Other fishes found stranded and entrapped in 1998 included northern pikeminnow, redside shiner, sucker, peamouth, threespine stickleback, sculpin, smallmouth bass, mountain whitefish (Prosopium williamsoni), dace (Rhinichthys spp.), common carp, lamprey (Lampetra spp.), bullhead (Ameiurus spp.), and yellow perch (Perca flavescens). This species were affected at different times and lifestages.

Fluctuations in water levels led to observed desiccation of the macroinvertebrate community during the 1998 investigation. U of I determined sampling parameters and protocols for the 1999 full-scale evaluation. USGS/BRD found that juvenile fall chinook salmon exposed to thermal stressors similar to those found on the Hanford Reach had no increased vulnerability to predation. COE collected detailed bathymetry on $35.1 \mathrm{~km}^{2}$ of the Hanford Reach from Rkm 571.3 to Rkm 606.9.

WDFW and the joint fish managers recommended that operations at Priest Rapids Dam create no fluctuations and/or steadily increasing flows on the Hanford Reach of the Columbia River throughout the juvenile fall chinook salmon emergence and rearing period. This recommendation was provided to the power managers who subsquentially proposed a Interim Protection Program to meet the follow criteria: 1) substantially more protection for juvenile fall chinook fry than occurred in 1998, 2) preservation of opportunity for loadfollowing/power peaking operations, 3) allow system coordinated river operations, 4) provide ability to monitor and evaluate in-season and adaptively manage operations to reduce stranding and entrapment. The proposed 
plan set forth the following operating scenarios: 1) limit daily fluctuations to a range of $+/-20 \mathrm{kcfs}$ (a range of $40 \mathrm{kcfs}$ ) when weekly average flows are less than $170 \mathrm{kcfs}, 2$ ) limit daily fluctuations to a range of $+/-30 \mathrm{kcfs}$ (a range of $60 \mathrm{kcfs}$ ) when weekly average flows are above $170 \mathrm{kcfs}$, and 3) rewetting of entrapment zones. Further development of the Interim Protection Program was continued in 1999.

\section{The 1999 Hanford Reach Juvenile Fall Chinook Salmon Interim Protection Program}

In 1999, an Interim Protection Program was developed and implemented on a trial basis in an attempt to safeguard rearing juvenile fall chinook salmon in the Hanford Reach. The program set operational constraints on flow fluctuations in the Hanford Reach during the fall chinook salmon emergence and rearing period.

Managing flow fluctuations in the Hanford Reach required the coordination of the seven dams upstream from Priest Rapids to Grand Coulee. Operational constraints limited flow fluctuations to a range of $40 \mathrm{kcfs}$ on a daily basis (60 kcfs on a daily basis during flow augmentation for outmigrating juvenile fish under NMFS Biological Opinion) when weekly average flows were less than $170 \mathrm{kcfs}$ at Priest Rapids Dam (NMFS 1995 and 1998). When weekly average flows were greater than $170 \mathrm{kcfs}$ at Priest Rapids Dam, flows were restricted to an hourly minimum of $150 \mathrm{kcfs}$. Evaluation of this pilot program was the focus of the 1999 work. The 1999 Hanford Reach Juvenile Fall Chinook Salmon Interim Protection Program is further detailed in Appendix A.

\section{Objectives}

The objectives for the 1999 evaluation were as follows:

1) Collect basic information on physical parameters of Hanford Reach as associated with stranding/entrapment events.

2) Evaluate the extent of juvenile post-emergent fall chinook salmon stranding and entrapment on the Hanford Reach resulting from river elevation reductions in the river section for which detailed bathymetric data has been collected.

3) Collect information on the effect of river elevation reductions on juvenile and adult fishes on the Hanford Reach below Priest Rapids Dam.

4) Identify critical habitat zones where juvenile fall chinook salmon are abundant and are more susceptible to stranding and entrapment as a result of river elevation reductions.

5) Determine the effect of diel water fluctuations on the benthic macroinvertebrate community.

6) Determine the effect of juvenile fall chinook salmon exposure to warm water and/or rapid water temperature change resulting from entrapment.

\section{Methods}

The methods used to achieve the established objectives included the processing of the SHOALS bathymetry data, designing a sampling plan to estimate the total number (within the area defined by the SHOALS data) of juvenile fall chinook salmon mortalities and fish at risk due to stranding and entrapment, estimating fry production on the Hanford Reach, surveying to determine relative abundance and size structure of the rearing fall chinook salmon population, surveying at night to assess predation on juvenile fall chinook salmon, surveying the stranding and entrapment of other fish species, investigating impacts of flow fluctuations to benthic macroinvertebrates, investigating thermal stress of juvenile fall chinook salmon and subsequent predation, and developing a juvenile fall chinook salmon susceptibility model.

\section{Scanning Hydrographic Operational Airborne Lidar Survey (SHOALS) Bathymetry Data}

COE collected detailed bathymetry data on a portion of the Hanford Reach in August 1998 using the SHOALS system. The SHOALS system consisted of an airborne laser transmitter/receiver capable of measuring 200 
soundings per second. The system was operated from a Bell 212 helicopter, flying at altitudes between 200 and $400 \mathrm{~m}$ with ground speed of 60 knots. The SHOALS system also included a ground-base data processing system for calculating accurate horizontal position and water depth. Depending on the complex interaction of radiance of bottom material, incident sun angle and intensity, and type and quantity of organics or sediments in the water column, the SHOALS system was capable of sensing bottom to depths equal to two or three times the Secchi depth (measure of transparency of the water). The horizontal positional accuracy of the data was $+/-3 \mathrm{~m}$ and the vertical positional accuracy was $+/-15 \mathrm{~cm}$.

SHOALS bathymetry data was used in conjunction with MASS1 unsteady flow model to characterize the Hanford Reach at a range of stage discharges. Water surface elevation maps of the Hanford Reach were created for each $10 \mathrm{kcfs}$ increment from 40 to $400 \mathrm{kcfs}$ using the MASS1 unsteady flow model and ARC/INFO based triangulated irregular network data models (TIN). These water surface elevation maps were superimposed on the SHOALS bathymetry data to generate shoreline maps for each increment. The shoreline maps were joined to establish the area of shoreline exposed by each $10 \mathrm{kcfs}$ flow reductions from 400 down to $40 \mathrm{kcfs}$.

\section{Estimates of Juvenile Fall Chinook Salmon Stranding and Entrapment}

A sampling plan was designed by PNNL and WDFW prior to the field season to estimate the total number of juvenile fall chinook salmon killed or placed at risk due to flow fluctuations during the implementation of the 1999 Interim Protection Program. The plan was developed for the portion of the Hanford Reach defined by the SHOALS bathymetry data from 40 to $400 \mathrm{kcfs}$.

The study area was classified into $40 \mathrm{kcfs}$ flow bands and divided into $3600 \mathrm{ft}^{2}\left(344.4 \mathrm{~m}^{2}\right)$ plots or sampling cells. The sample plot size was based on the mean size of entrapments found in 1998. Sample plots that crossed the line between designated $40 \mathrm{kcfs}$ flow bands were included in the flow band that contained at least $50 \%$ of the cell. Cells that did not include a majority of one $40 \mathrm{kcfs}$ flow band were removed from consideration. A list of all cells contained within the study area was compiled and cells were randomly selected to use in daily field sampling activities. Daily sampling targeted wetted flow bands identified in the previous 48-hour flow history.

Initiation of field activities was based upon juvenile fall chinook salmon emergence timing as calculated under the terms of the 1988 Vernita Bar Settlement Agreement. Because fall chinook salmon spawning and subsequent spring emergence may occur earlier than predicted, field operations were initiated approximately one week prior to the calculated start of emergence to ensure maximum protection of newly emergent fall chinook salmon. Implementation of the 1999 Interim Protection Program and field sampling was based on population surveys conducted at six index sites. Detailed information regarding the 1999 Interim Protection Program initiation criteria is included in Appendix A.

Two field teams comprised of WDFW, GCPUD, and Yakama Nation (YN) personnel collected data daily during the fall chinook salmon emergence and rearing period when wetted shorelines were visible. The crews chose sample locations in the appropriate flow bands from the list of randomly generated sample plots prior to sampling. A high-performance global positioning system (GPS) with submeter accuracy was used to navigate to the sample locations.

An anchor attached to an incrementally marked rope was placed at the center of each sample plot to delineate the circular boundary of the plot. The number of juvenile fall chinook salmon and other species of fish found within the sample plot were counted and classified as alive or dead. If entrapments were encountered, an assessment was made to determine the percentage of the entrapment contained within the sample plot.

Entrapments with area of 50\% or greater within the circle were sampled in their entirety. Entrapments with area of greater than $50 \%$ outside of the circle were not surveyed. In cases where portions of the plot were dry or under water at the river's edge, the marked rope was used to measure the amount of wetted shoreline. A scaled drawing was produced to calculate the proportion of the plot contained within the fluctuation zone. Other data recorded at the sites included bird activity (i.e., tracks), entrapment water temperatures, dominant and subdominant substrate size, substrate embeddedness, and vegetation density. Dominant and subdominant substrate size were classified according to a modified Wentworth code (Platts et al. 1983); substrate embeddedness was classified according to Platts et al. (1983); and vegetation density was recorded as absent, 
sparse, medium, or dense (Appendix B). Methods for calculating the estimated total number of juvenile fall chinook salmon mortalities and at risk due to stranding and entrapment are provided in Appendix $\mathbf{C}$.

\section{Fall Chinook Salmon Fry Production Estimate}

A coarse estimate of the 1999 fall chinook salmon fry production in the Hanford Reach was calculated to gauge the proportion of the population affected by flow fluctuations. The estimate was based on 1998 adult fall chinook salmon escapement to the Hanford Reach, female composition of the escapement, fecundity, egg retention, and egg to emergence/fry/smolt mortality. Information on escapement (number and percent female) and egg retention was obtained from the 1998 WDFW Hanford Reach carcass and creel surveys (Watson 1999). The sex composition of Hanford Reach spawners was derived from the sport fishery harvest data collected during these surveys (Appendix D). It was assumed that anglers had an equal chance of harvesting a male or female and there was no behavioral characteristics associated with gender that would bias catch. Fecundity rates have not been established for naturally spawning fall chinook salmon on the Hanford Reach but, for this estimate, it was assumed that these rates were similar to rates of fall chinook salmon sampled at Priest Rapids Hatchery. No studies have been conducted on egg to emergence/fry/smolt mortality rates of fall chinook salmon on the Hanford Reach. Mortality rates used in this estimate were selected from a compilation of other studies gathered by Healey (1998) (Appendix D). Healey (1998) reports that, under natural conditions, 30\% or less of the potential eggs deposited resulted in emergent fry or fry and fingerling migrants in the systems studied. The mean mortality rates reported in three studies of natural spawners that were not influenced by flood events or controlled flows were used in this estimate. The studies included one from California (Wales and Coots 1954) and two from British Columbia (Lister et al. 1971, Healey 1980).

\section{Assessment of Juvenile Fall Chinook Salmon Relative Abundance and Fork Length}

Juvenile fall chinook salmon were seined from six nearshore sampling sites on the Hanford Reach once a week during the emergence and rearing period to assess relative abundance and fish size. The six sites included three at Locke Island (Rkm 597.0, 599.5, and 600.7), one upstream of $100 \mathrm{~F}$ Islands (Rkm 593.1), one at $100 \mathrm{~F}$ Islands (Rkm 591.4), and one at the downstream end of Savage Island (Rkm 573.2). Seining techniques were similar to methods described by Key et al. (1994).

A beach seine, $21.3 \mathrm{~m} \mathrm{x} 1.8 \mathrm{~m}$ with a $1.8 \mathrm{~m}^{2} \mathrm{bag}, 4.8 \mathrm{~mm}$ diamond mesh, and $15.2 \mathrm{~m}$ leads, was used to collect juvenile fall chinook salmon and other fish species from the six designated nearshore sampling sites. One lead of the seine was cleated to the bow of a $5.5 \mathrm{~m}$ boat, the seine was folded and laid on the bow, and the other lead was held by a person on shore. The boat was then backed perpendicular to shore to a distance of $15.2 \mathrm{~m}$ and then backed upstream allowing the seine to be fed out parallel to shore. Once the seine was unfurled, the boat was maneuvered back into shore. Both ends of the seine were then simultaneously hauled to shore. The area sampled in this manner was approximately $320 \mathrm{~m}^{2}$. When samples contained less than 40 juvenile fall chinook salmon, all fish were anesthetized with tricaine methanesulfonate (MS-222), measured, and fork lengths were recorded. Samples containing over 40 juvenile fall chinook salmon were sub-sampled to obtain approximately 30 fish. Fish sub-sampled were anesthetized and fork lengths were recorded; the remaining fish were counted. All fish were released back into the river. Temperature, dominant and subdominant substrate size (modified Wentworth code; Platts et al. 1983), substrate embeddedness (Platts et al. 1983), and vegetation density (absent, sparse, medium, or dense) were recorded for each site (Appendix B).

\section{Evaluation of Potential Mortality Events in Primary Fall Chinook Salmon Rearing Areas}

An emergency management team (EMT) consisting of WDFW and YN personnel monitored primary fall chinook salmon rearing areas for potential mortality events. The objective of the EMT was to identify flow fluctuation events that posed risks to large numbers of juvenile fall chinook salmon. When such events were identified, a pre-established notification procedure was used to request immediate corrective action.

The EMT inspected one of three sites daily. The sites included Locke Island (Rkm 600.0), 100 F Islands (Rkm 591.0), and Wooded Island (Rkm 562.0). The EMT alternated through these sites in consecutive order. Observation entrapments were established at each of the sites and used to index conditions throughout the Hanford Reach. Multiple entrapments were identified and marked at each site so that the full range of flow 
conditions could be indexed. When entrapments containing juvenile fall chinook salmon were observed, all fish were seined, counted, and released into the river. After removal of the fish, water temperatures and drainage rates were monitored in the entrapments throughout the day. If two or more entrapments previously containing juvenile fall chinook salmon reached $24^{\circ} \mathrm{C}$ or drainage of the entrapments was imminent, the EMT would contact the other field crews to verify that similar detrimental conditions were present in other areas of the Hanford Reach. When conditions warranted, the field crew leader would call the designated GCPUD personnel to request immediate re-wetting or other operational solutions.

\section{Surveys of Other Fish Species}

Data pertaining to fish species other than fall chinook salmon were collected during the spring period in concurrence with the evaluation of the 1999 Interim Protection Program. Survey work continued through the summer period to reference the effect of flow fluctuations on these other species under the same summer sampling protocol as used in 1998 (Nugent et al. 2001). The following section details the work conducted in the summer and early fall. This work included surveys for stranding and entrapment as well as an evaluation of composition, abundance, and growth of nearshore fish species.

\section{Surveys of Stranding and Entrapment}

Shoreline areas within the 24-hour river fluctuation zone were surveyed approximately once a week for stranding and entrapment sites during summer and early fall. Sites were selected from a range of river elevations and habitat types throughout the Hanford Reach.

Selected sites were given an identification code, a sample time, and a location to the nearest $0.2 \mathrm{Rkm}$. Each site was sampled only once during the season. Physical measurements were collected at each site. Water quality measurements were taken in the river adjacent to each site. Water quality measurements were also collected in entrapments if present.

Recorded physical measurements of stranding and entrapment sites included distance to river, elevation of the re-inundation point of the depression, dominant and subdominant substrate, substrate embeddedness, and vegetation density. Physical measurements of entrapments also included size, depth, and drainage rate from the beginning to the end of the sample interval, and drainage or re-inundation times if occurring during the sample interval.

Distance to river was measured as the closest distance from the re-inundation point of the depression to the river along the most probable watercourse. The elevation of the re-inundation point of the depression was determined by surveying the point in relationship to the elevation of the river surface. The river elevation was determined using the sample time and MASS1. Dominant and subdominant substrate were classified according to a modified Wentworth code (Platts et al. 1983); substrate embeddedness was classified according to Platts et al. (1983); and vegetation density was recorded as absent, sparse, medium, or dense (Appendix B). The size of the entrapments was estimated by recording one length and three width measurements. Depths were measured at quarter length intervals along the width measurements. A staff gauge was used to measure drainage rates in the entrapment by taking water level measurements at the beginning and the end of the sample interval.

Water quality measurements recorded from each entrapment and nearshore area adjacent to the site included dissolved oxygen, percent oxygen saturation, and water temperature. Dissolved oxygen and percent oxygen saturation were recorded at the beginning of the sample interval and water temperatures were recorded at the beginning and end of the sample interval.

All sites were surveyed for fish. Fish found were either classified as at risk or as mortalities. Mortality events were recorded as thermal or stranding. Occurrences in which fish were found unwatered or in entrapments that drained during sampling were classified and recorded as stranding mortality events.

Fish in entrapments were caught using dip nets or a stick seine $\left(15.2 \mathrm{~m} \mathrm{x} 1.2 \mathrm{~m}\right.$ with a $1.2 \mathrm{~m}^{2}$ bag with $0.8 \mathrm{~mm}$ diamond mesh). An effort was made to collect all fish in the entrapments. Larger fish were anesthetized with MS-222, identified to species (or lowest possible taxa), counted, and measured. The fish were allowed to 
recover and were released into the river. All mortalities were hand collected, identified to species (or lowest possible taxa), counted, and measured.

\section{Evaluation of Composition, Abundance, and Growth of Other Fish Species along Shorelines}

In addition to stranding and entrapment surveys, WDFW field personnel worked in conjunction with USGS/BRD larval fish researchers in sampling nearshore sites. Eight nearshore sites were sampled weekly during the summer and early fall. These sites consisted of six main channel and two slough sites. The six main river channel sites included three at Locke Island (Rkm 598.1, 600.5, and 600.5), two at $100 \mathrm{~F}$ Islands (Rkm 591.1 and 591.3), and one at the Hanford Townsite ( $\mathrm{Rkm}$ 582.0). The two slough sites were located in Hanford Slough (both at Rkm 583.1). White Bluffs Slough, sampled in 1998, was not sampled in 1999. DOE placed ingress/egress restrictions on White Bluffs Slough due to a pair of nesting bald eagles.

Nearshore sites were sampled using a small beach seine $\left(15.2 \mathrm{~m} \times 1.2 \mathrm{~m}\right.$ with a $1.2 \mathrm{~m}^{2}$ bag and a mesh size of $0.8 \mathrm{~mm}$ ), following the methods of Barfoot et al. (1999). To collect fish, the seine was pulled perpendicular to the shore from a depth of one meter or from a distance of 15 meters from the shore whichever was attained first.

Fish collected that were large enough to be identified in the field were anesthetized with MS-222, measured, recorded, and released. Larval fish and smaller juvenile fish collected were preserved in $10 \%$ buffered formalin and transported to the USGS/BRD laboratory for analysis. In the situation where large numbers of larval fish were collected, volumetric sub-sampling was performed and excess fish were released back into the river.

At the laboratory, preserved samples of larval and juvenile fish were sorted, identified to the lowest possible taxa and counted. Larval fish numbers by taxa were estimated using simple extrapolation of the sub-samples. A maximum of 50 specimens of each taxa were randomly selected and measured to the nearest $0.1 \mathrm{~mm}$ standard length.

Water quality parameters were collected at all index sites during each sample event. Water temperatures were recorded at mid-depth offshore at the most distant point of the seine haul and at a $20 \mathrm{~cm}$ depth near shore.

\section{Night Surveys of Predation on Stranded and Entrapped Juvenile Fall Chinook Salmon}

Two night surveys were conducted from dusk through dawn during the 1999 field season. Night surveys were performed to assess predation on juvenile fall chinook salmon by black-crowned night herons (Nycticorax nycticorax) and other avian predators. Investigations were conducted in two major rearing areas, one on $100 \mathrm{~F}$ Islands (Rkm 591.0) and one in Hanford Slough (Rkm 584.5). WDFW personnel used night vision scopes to perform observations throughout the night.

\section{Evaluation of the Effects of Fluctuations on the Benthic Macroinvertebrate Community}

A two-year evaluation to assess the effects of water fluctuations on the benthic macroinvertebrate community of the Hanford Reach was initiated by U of I and SPC in 1998. U of I and SPC evaluated both the long and shortterm effects of diel water fluctuations on the benthic macroinvertebrate community. A complete description of the methods used to conduct this work is detailed in Appendix $\mathbf{E}$ and are summarized here.

A preliminary survey was performed in 1998 to determine the optimal locations, artificial substrates and colonization periods for the 1999 evaluation of long-term effects of diel water fluctuations on the benthic macroinvertebrate community. Two sampling sites were selected for the 1999 long-term evaluation, one at Rkm 592.2 and the other at Rkm 596.2. Twenty lines containing ten optimally spaced brick substrates were deployed at each location in 1999. The lines of bricks were positioned parallel to the river flow at depths of constant inundation for a colonization period of four weeks. The lines of bricks were then rotated perpendicular to the shoreline and situated so that each line had a continuum of the brick substrates that ranged from constant inundation to constant air exposure. The brick substrates were exposed to diel water fluctuations from Priest Rapids Dam. Pressure sensors were placed about one meter below the level of constant inundation to detect the frequency and duration of water level fluctuations. The elevation of the bricks and pressure sensors were also 
determined using laser level surveying equipment. The inundation history of each brick could then be calculated.

The bricks were retrieved after 21 days and care was taken to avoid dislodging the colonized organisms. Each substrate was placed in an individual plastic bucket with water and disconnected from the line. The bricks were then brushed and rinsed of all attached organisms into the bucket. Each bucket was poured through a $0.595 \mathrm{~mm}$ sieve, rinsed into sample containers, and preserved in 10\% formalin solution with rose bengal dye (Mason and Yevich 1967). All samples were transported to the laboratory for sorting, identification, enumeration, and weighing.

Short-term effects of diel water fluctuations on the benthic macroinvertebrate community of the Hanford Reach were assessed through investigation of invertebrate drift response and artificial exposure tests. Potential drift and subsequent recolonization of macroinvertebrates within diel hydropeaking cycles were determined by drift sampling. Drift sampling was performed using paired $30 \mathrm{~cm}^{2}$ drift nets with $250 \mu \mathrm{m}$ mesh openings placed on or near the bottom (White et al. 1985). Samples were collected for 30 minutes in duration at 3-hour intervals. Velocity measurements were taken in the net opening at 0.6 the net height using a Swoffer (M2000) velocity meter. Velocities were recorded at the beginning, middle, and end of the sampling period to obtain an estimate of average velocity.

Drift sampling was conducted at depths of $0.45,0.75$, and $1.0 \mathrm{~m}$ using staked nets and at depths of 1.5 and 2.1 $\mathrm{m}$ using an anchored boat. Net placement was chosen to ensure the nets were completely inundated regardless of discharge. Discharge passing through the nets was calculated for each sample period by multiplying the water velocity by the area of the net opening. Water levels were recorded using the established pressure sensors. Reference discharge data was also obtained from GCPUD.

Artificial exposure tests were performed to determine the effects of short-term air exposure on macroinvertebrates. Ten lines containing eight equally spaced brick substrates were positioned parallel to the river flow at depths of constant inundation and allowed to colonize with macroinvertebrates for a period of four weeks. The bricks were then retrieved and placed in individual containers on small pieces of tile. The tiles were used to assess relative movement or vertical migration of macroinvertebrates as the organisms attempted to avoid desiccation. Test bricks were exposed to air for time periods typical of normal hydropeaking cycles. A minimum of six replicate bricks was sampled for each exposure period to maintain statistical power.

Exposure tests were terminated by adding water to the containers. Bricks and tiles were then processed using the long-term effects sampling procedures. Bricks and tiles were treated separately for each sample for all exposure durations. A single brick was sub-sampled from each exposure test and field analyzed using a dissecting scope. Macroinvertebrates were sorted into live or dead categories, preserved, and processed according to methods described above in the long-term effects sampling procedures.

\section{Investigation of Thermal Tolerance and Predation on Juvenile Fall Chinook Salmon}

USGS/BRD assessed effects of thermal stressors on performance of Hanford Reach juvenile fall chinook salmon by exposing fish to heat stress scenarios similar to monitored entrapments on the Hanford Reach. Specific objectives of the laboratory work were to assess the extent of direct mortality, vulnerability to predation by smallmouth bass, physiological stress responses, and synthesis of heat shock protein 70 (hsp70). Detailed methods are provided in Appendix F.

\section{Modeling of Juvenile Fall Chinook Salmon Susceptibility to Stranding and Entrapment}

PNNL has been subcontracted to provide a juvenile fall chinook salmon susceptibility model for the Hanford Reach. The model will be developed to examine and evaluate flow reduction scenarios and associated juvenile fall chinook salmon mortality. Integration of prior and subsequent years data will be used to complete the model. The data to be incorporated includes detailed river bathymetry (SHOALS data), the unsteady flow model (MASS1), biological data such as emergence timing, population structure, fish size and rate of growth, as well as other physical habitat parameters including, water temperature, substrate size, substrate embeddedness, and vegetation density. 


\section{Results}

This section of the document provides a description of the 1999 Hanford Reach conditions and a compilation of the results of the 1999 evaluation.

\section{Hanford Reach Flows and Meteorological Conditions}

River and meteorological conditions on the Hanford Reach during the 1999 juvenile fall chinook salmon emergence and rearing period (March-July) were marked by above average river flows, below normal ambient air temperatures, below normal precipitation, and above average solar radiation levels (Table 1). Comparison of 1999 flows to 10-year mean flows (1989-1998) indicates that 1999 was above average for all months except May. Flows in May 1999 were $162.0 \mathrm{kcfs}$, only slightly below the previous ten-year average of $168.1 \mathrm{kcfs}$. Air temperatures were below normal during the 1999 juvenile fall chinook salmon emergence and rearing period with the exception of March. March air temperatures averaged $0.4^{\circ} \mathrm{C}$ above normal (Hanford Meteorological Station, PNNL 2000). Precipitation during 1999 was below normal for the entire year (Hanford Meteorological Station, PNNL 2000). Solar radiation levels, a good indication of cloud cover, were above the 19-year mean (1980-1998) during the 1999 juvenile fall chinook salmon emergence and rearing period with the exception of March. March solar radiation levels were 3.9 langleys below the 19-year mean March level (Hanford Meteorological Station, PNNL 2000).

Table 1. Comparison of 1999 monthly average river flows, air temperatures, precipitation, and solar radiation levels to past years on the Hanford Reach of the Columbia River.

\begin{tabular}{|c|c|c|c|c|c|c|c|c|c|c|c|c|}
\hline \multicolumn{13}{|c|}{ River Flows $^{1}$ (kcfs) } \\
\hline & Jan. & Feb. & Mar. & Apr. & May & June & July & Aug. & Sept. & Oct. & Nov. & Dec. \\
\hline 1999 & 139.4 & 145.4 & 137.6 & 143.2 & 162.0 & 191.2 & 183.9 & 161.5 & 111.6 & 94.4 & 114.2 & 152.3 \\
\hline Mean (1989-1998) & 124.1 & 128.8 & 118.6 & 119.9 & 168.1 & 182.4 & 134.0 & 106.7 & 80.1 & 84.5 & 98.2 & 118.5 \\
\hline Departure & +15.3 & +16.6 & +19.0 & +23.3 & -6.1 & +8.8 & +49.9 & +54.8 & +31.5 & +9.9 & +16.0 & 33.8 \\
\hline \multicolumn{13}{|c|}{ Air Temperature ${ }^{2}\left({ }^{0} \mathrm{C}\right)$} \\
\hline & Jan. & Feb. & Mar. & Apr. & May & June & July & Aug. & Sept. & Oct. & Nov. & Dec. \\
\hline 1999 & 3.5 & 5.4 & 7.9 & 10.5 & 14.4 & 19.7 & 23.2 & 24.6 & 18.3 & 11.0 & 7.7 & 3.2 \\
\hline Normal (1961-1990) & -0.4 & 3.3 & 7.6 & 11.5 & 16.3 & 20.9 & 24.6 & 23.9 & 18.7 & 11.6 & 4.6 & -0.3 \\
\hline Departure & +3.9 & +2.1 & +0.4 & -1.0 & -1.9 & -1.3 & -1.3 & +0.6 & -0.4 & -0.6 & +3.1 & 3.5 \\
\hline \multicolumn{13}{|c|}{ Precipitation $^{2}(\mathrm{~cm})$} \\
\hline & Jan. & Feb. & Mar. & Apr. & May & June & July & Aug. & Sept. & Oct. & Nov. & Dec. \\
\hline 1999 & 0.9 & 0.7 & 0.1 & Trace & 0.3 & 0.3 & 0.1 & 0.6 & 0.0 & 0.5 & 0.3 & 0.1 \\
\hline Normal (1961-1990) & 2.0 & 1.6 & 1.2 & 1.0 & 1.3 & 1.0 & 0.5 & 0.7 & 0.8 & 1.0 & 2.3 & 2.6 \\
\hline Departure & -1.1 & -0.9 & -1.1 & -1.0 & -1.0 & -0.7 & -0.4 & -0.1 & -0.8 & -0.5 & -2.1 & -2.5 \\
\hline \multicolumn{13}{|c|}{ Solar Radiation ${ }^{2}$ (Langleys) } \\
\hline & Jan. & Feb. & Mar. & Apr. & May & June & July & Aug. & Sept. & Oct. & Nov. & Dec. \\
\hline 1999 & 82.0 & 154.9 & 296.4 & 433.0 & 546.6 & 585.7 & 643.1 & 483.4 & 425.0 & 241.1 & 106.8 & 69.9 \\
\hline Mean (1980-1998) & 96.5 & 170.4 & 300.3 & 424.6 & 516.5 & 575.4 & 598.3 & 523.7 & 388.0 & 241.9 & 116.5 & 76.5 \\
\hline Departure & -14.5 & -15.5 & -3.9 & +8.4 & +30.1 & +10.3 & +44.8 & -40.3 & +37.0 & -0.8 & -9.7 & -6.6 \\
\hline
\end{tabular}

${ }^{1}$ Data from USGS Gauging Station 12472800 below Priest Rapids Dam

${ }^{2}$ Data from Hanford Meteorological Station, PNNL

\section{Implementation Timing and Operation of the 1999 Hanford Reach Juvenile Fall Chinook Salmon Interim Protection Program}

All aspects of the Interim Protection Program were subject to evaluation and modification during the initial year (1999) of implementation. A working Interim Protection Program was agreed upon by the Hanford Policy Group just prior to the calculated start of 1999 fall chinook salmon emergence (Appendix A). As a precautionary measure, field activities commenced before estimated emergence of juvenile fall chinook salmon to ensure maximum protection while the implementation criteria were under development. 
Emergence of wild juvenile fall chinook salmon in 1999, as calculated under the terms of the 1988 Vernita Bar Settlement Agreement, was estimated to start on March 8. Population index surveys were subsequently initiated on March 5 to account for possible early emergence. Implementation of the 1999 Interim Protection Program began March 10 although the actual implementation criteria were not satisfied until March 24.

Random sampling to assess the effectiveness of the 1999 Interim Protection Program began on March 19. The program and concurrent evaluation field activities were continued through June 30.

A strategy for rewetting entrapment zones was initiated in 1999 but was discontinued early due to the increased number and magnitude of the fluctuations necessary to perform this operation and the potential for entrapping additional fish.

Priest Rapids Dam (Rkm 639.1) discharges averaged 161.4 kcfs from March 8 through June 30 in 1999. Hourly discharge from the Dam ranged from 61.9 to $261.3 \mathrm{kcfs}$ (Figure 7). Mean daily fluctuation during this period was $42.1 \mathrm{kcfs}$. A $17 \mathrm{kcfs}$ fluctuation in discharge equates to a vertical change in river elevation of approximately one foot $(0.3 \mathrm{~m})$ at Vernita Bar (Rkm 632.4). The primary period of susceptibility of juvenile fall chinook salmon to stranding in 1999 based on fish recorded as "mortalities" and "at risk" in random samples and length frequency distribution from index sampling appears to be from the start of emergence to May 29. Mean daily flow fluctuation from Priest Rapids Dam during the primary period of susceptibility was $36.0 \mathrm{kcfs}$ with 13 days of relatively stable flows (fluctuations $<20 \mathrm{kcfs}$ ) and 26 days of flow fluctuations greater than $40 \mathrm{kcfs}$ ( 6 days of flow fluctuations greater than $80 \mathrm{kcfs}$ ) (Table $2 \&$ Figure 8).

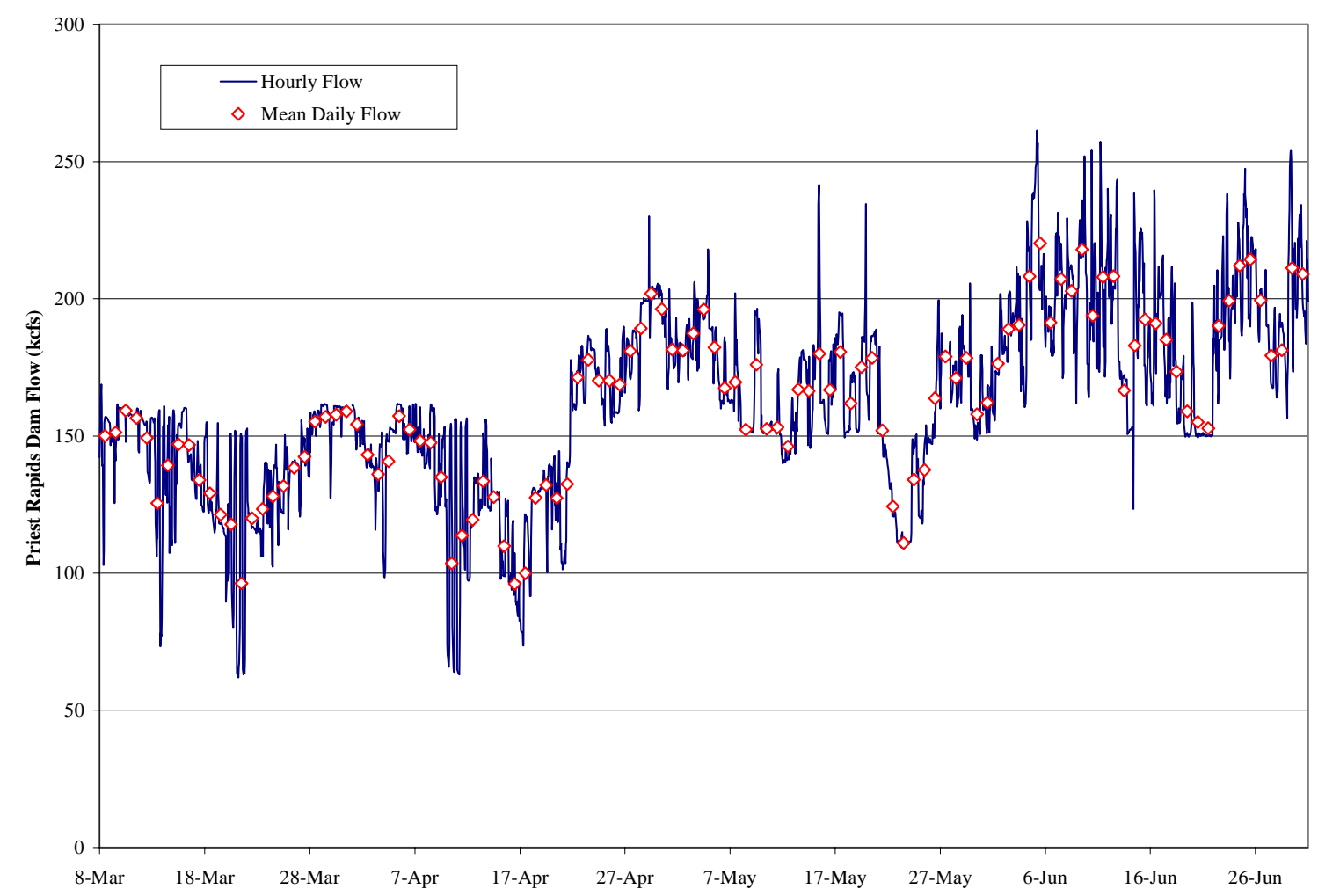

Figure 7. Hourly and mean daily flows from Priest Rapids Dam on the Columbia River (March 8-June 30, 1999). 
Table 2. Daily fluctuations in flow from Priest Rapids Dam on the Columbia River (March 8-June 30, 1999).

\begin{tabular}{|c|c|c|c|c|c|c|}
\hline & Mean Flow & \multicolumn{5}{|c|}{ Number of Days } \\
\cline { 3 - 7 } Date & Fluctuation (kcfs) & $\langle\mathbf{2 0}$ kcfs (stable) & $\mathbf{2 0 - 4 0 ~ k c f s}$ & $\mathbf{4 0 - 6 0}$ kcfs & $\mathbf{6 0 - 8 0}$ kcfs & $>\mathbf{8 0}$ kcfs \\
\hline March 8-May 29 & 36.0 & 13 & 44 & 17 & 3 & 6 \\
May 30-June30 & 49.8 & 0 & 8 & 10 & 10 & 4 \\
\hline Total & 42.1 & 13 & 52 & 27 & 13 & 10 \\
\hline
\end{tabular}

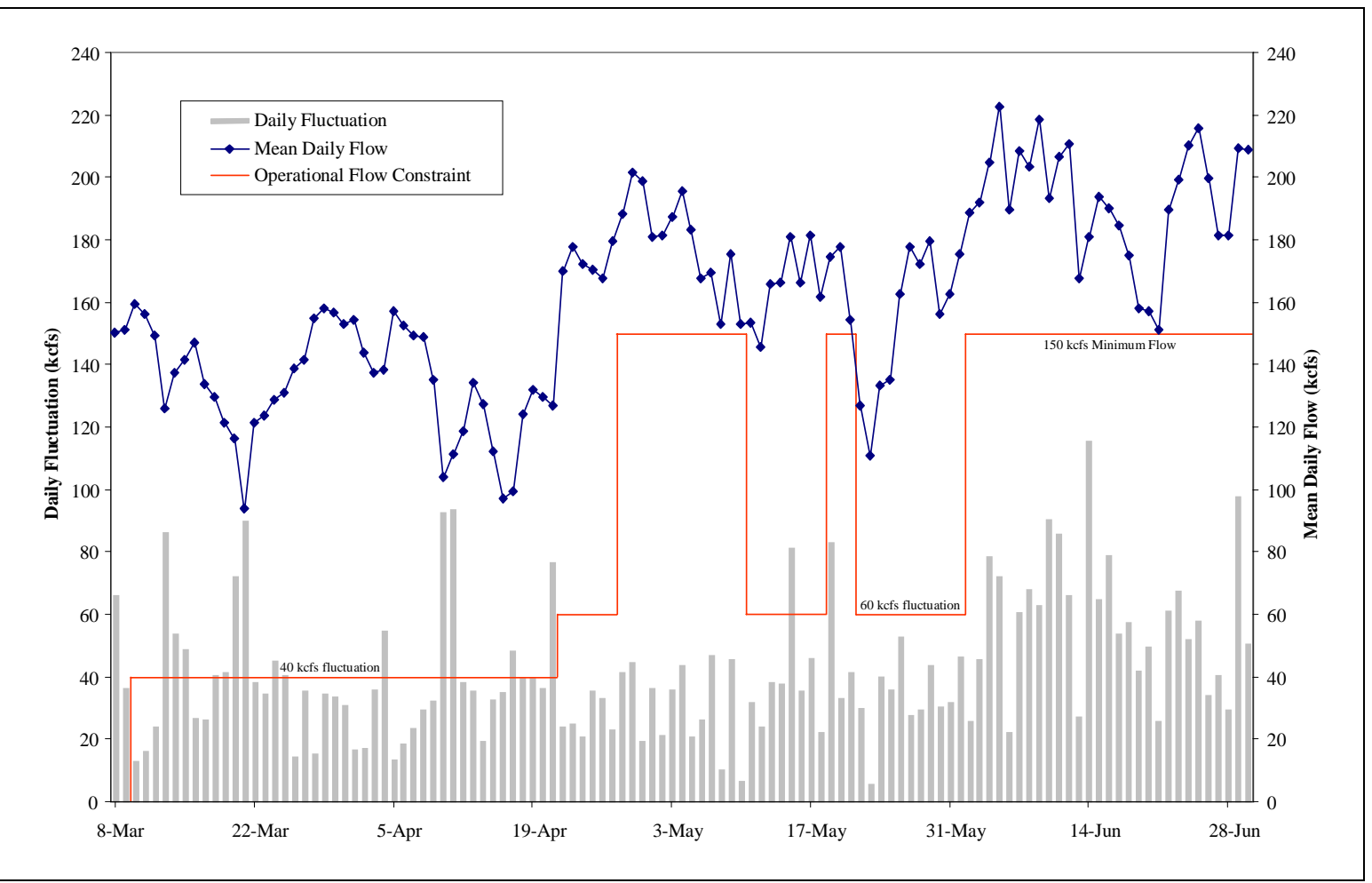

Figure 8. Mean daily flow, daily fluctuation in flow, and operational flow constraints for Priest Rapids Dam on the Columbia River (March 8-June 30, 1999).

\section{Scanning Hydrographic Operational Airborne Lidar Survey (SHOALS) Bathymetry Data}

COE collected detailed SHOALS bathymetry data in 1998 on $35.1 \mathrm{~km}^{2}$ of the Hanford Reach from Rkm 571.3 to Rkm 606.9 (Figure 9). These data were used in conjunction with MASS1 unsteady flow model to provide information on the Hanford Reach at a range of stage discharges. From this information, the extent of area of shoreline exposed by flow fluctuations and the configuration of the river channel could be determined. The area of shoreline exposed for a portion of the Hanford Reach (100 F Islands) during the 1999 juvenile fall chinook salmon emergence and rearing period is illustrated in Figure 10 as an example of this information. Figure 11 shows the amount of area of shoreline within each $10 \mathrm{kcfs}$ flow fluctuation zone for the portion of the Hanford Reach defined by the SHOALS data. The area of shoreline exposed by flow fluctuations at lower river elevations (40kcfs - $110 \mathrm{kcfs}$ ) is much larger than at higher fluctuation zones. However, the amount of shoreline exposed at some flow levels actually increases with increasing river elevations (i.e., 170-180 kcfs) suggesting steep banks may give way to flats or flood terraces. The extent of steep banks and flood terraces vary with river kilometer (Figure 12). This can be observed in the river cross-sections presented in Figure 13. The smaller amount of exposed shoreline in the 40-50 kcfs flow fluctuation in Figure 11 may indicate the main river channel. 


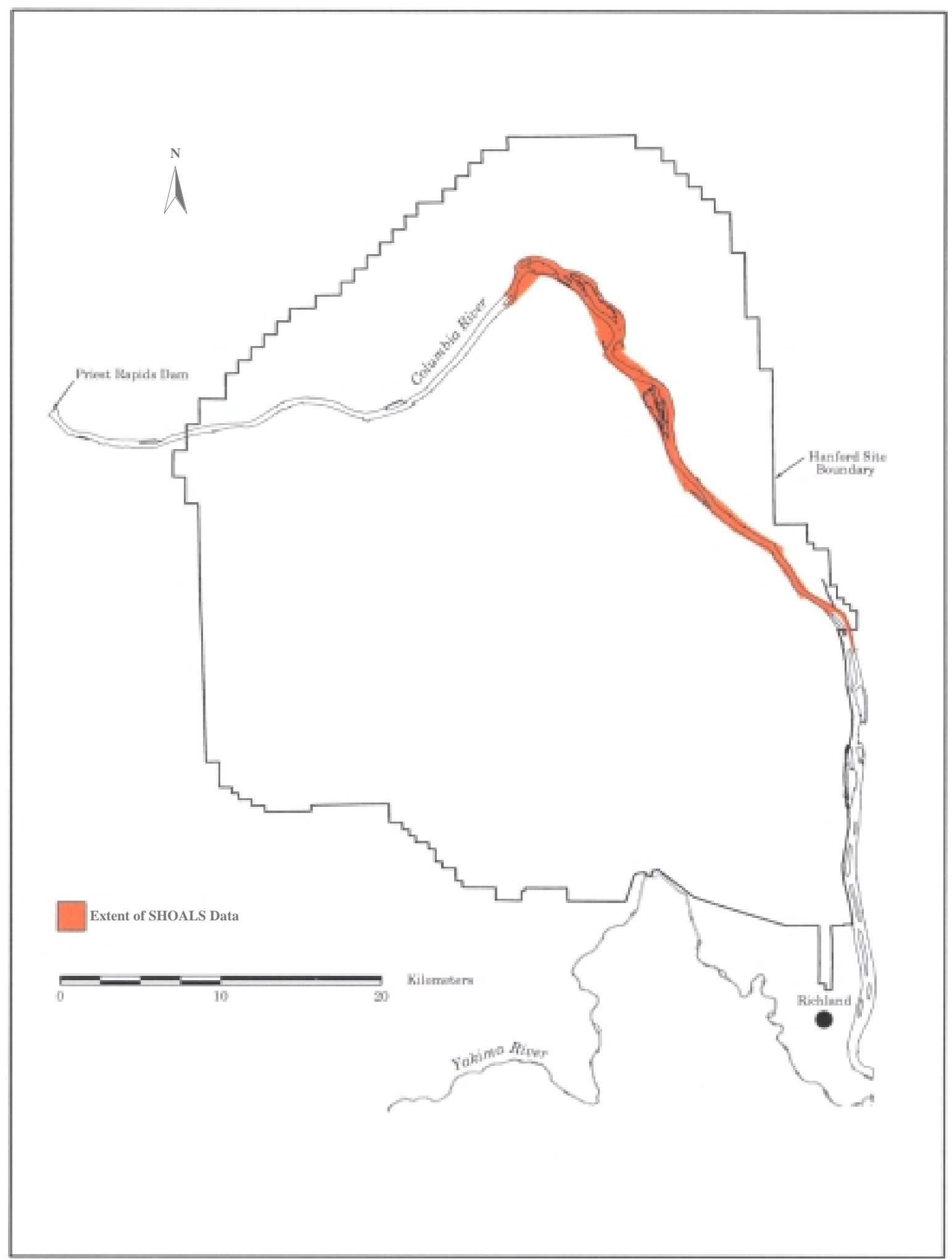

Figure 9. Area of the Hanford Reach of the Columbia River where detailed bathymetry data has been collected using the Scanning Hydrographic Operational Airborne Lidar Survey (SHOALS). 


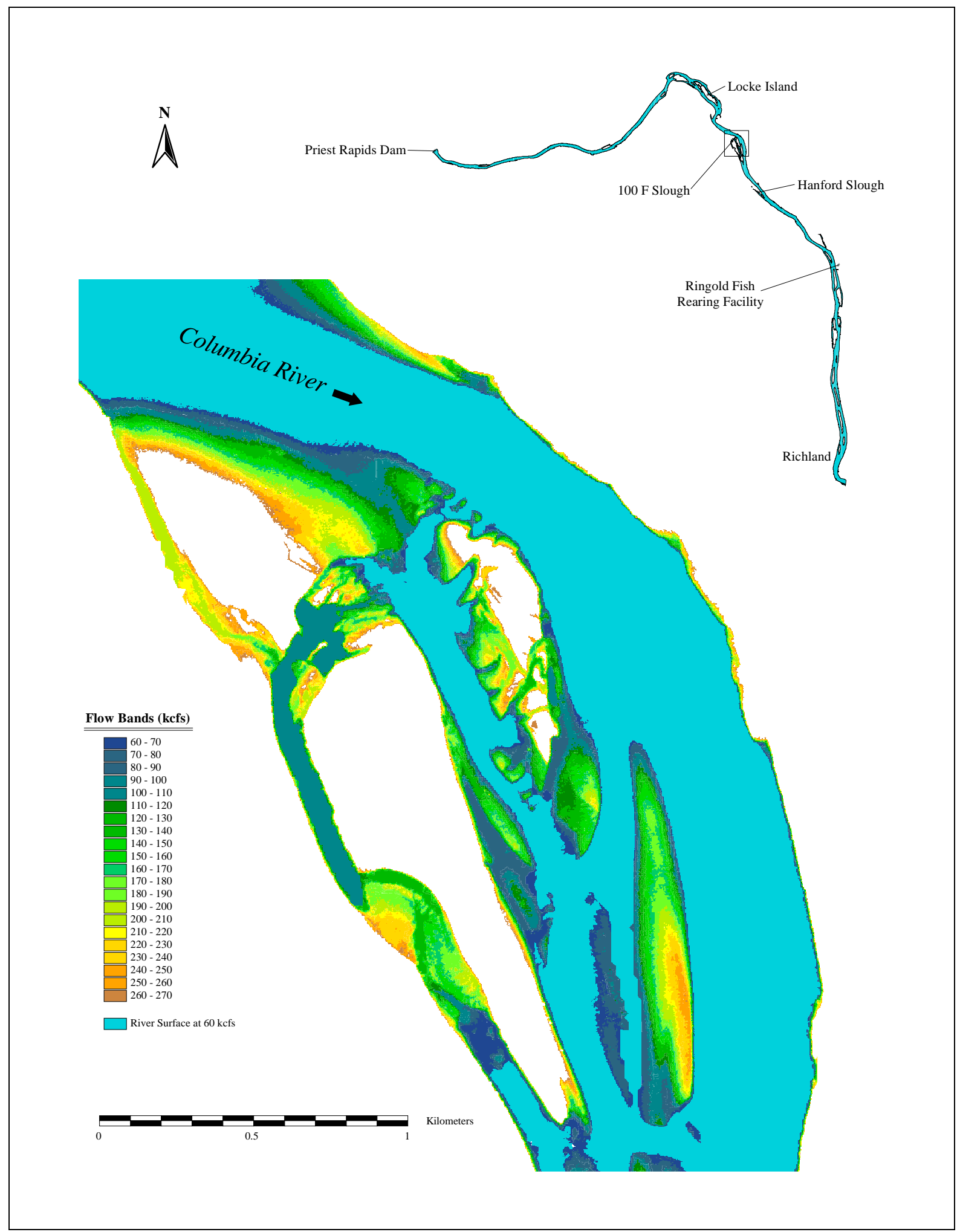

Figure 10. The extent of shoreline exposed in the $100 \mathrm{~F}$ Islands area of the Hanford Reach of the Columbia River during the juvenile fall chinook salmon emergence and rearing period in 1999. 


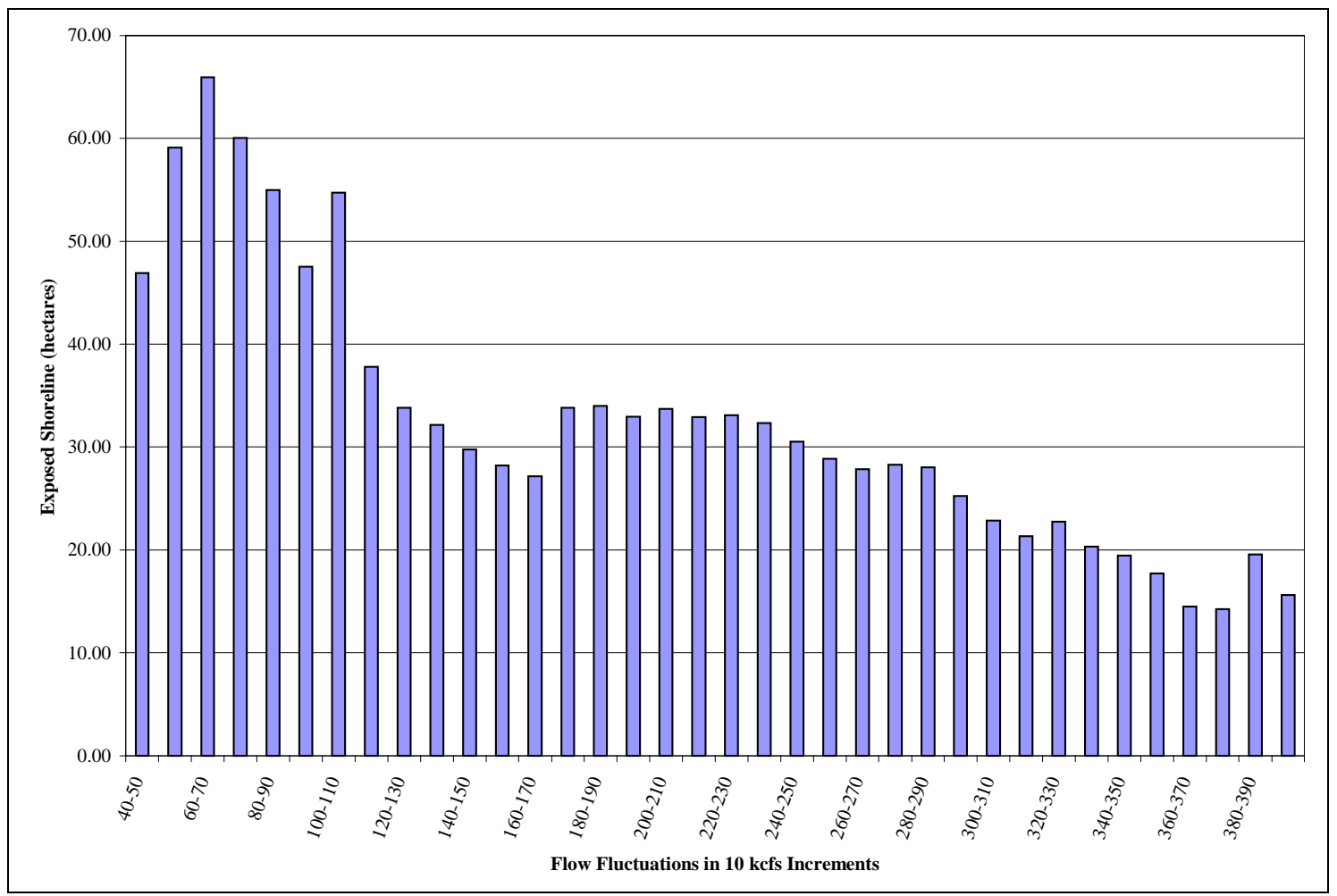

Figure 11. The area of shoreline exposed within each $10 \mathrm{kcfs}$ flow band for the portion of the Hanford Reach of the Columbia River defined by the SHOALS data (Rkm 571.3 to Rkm 606.9).

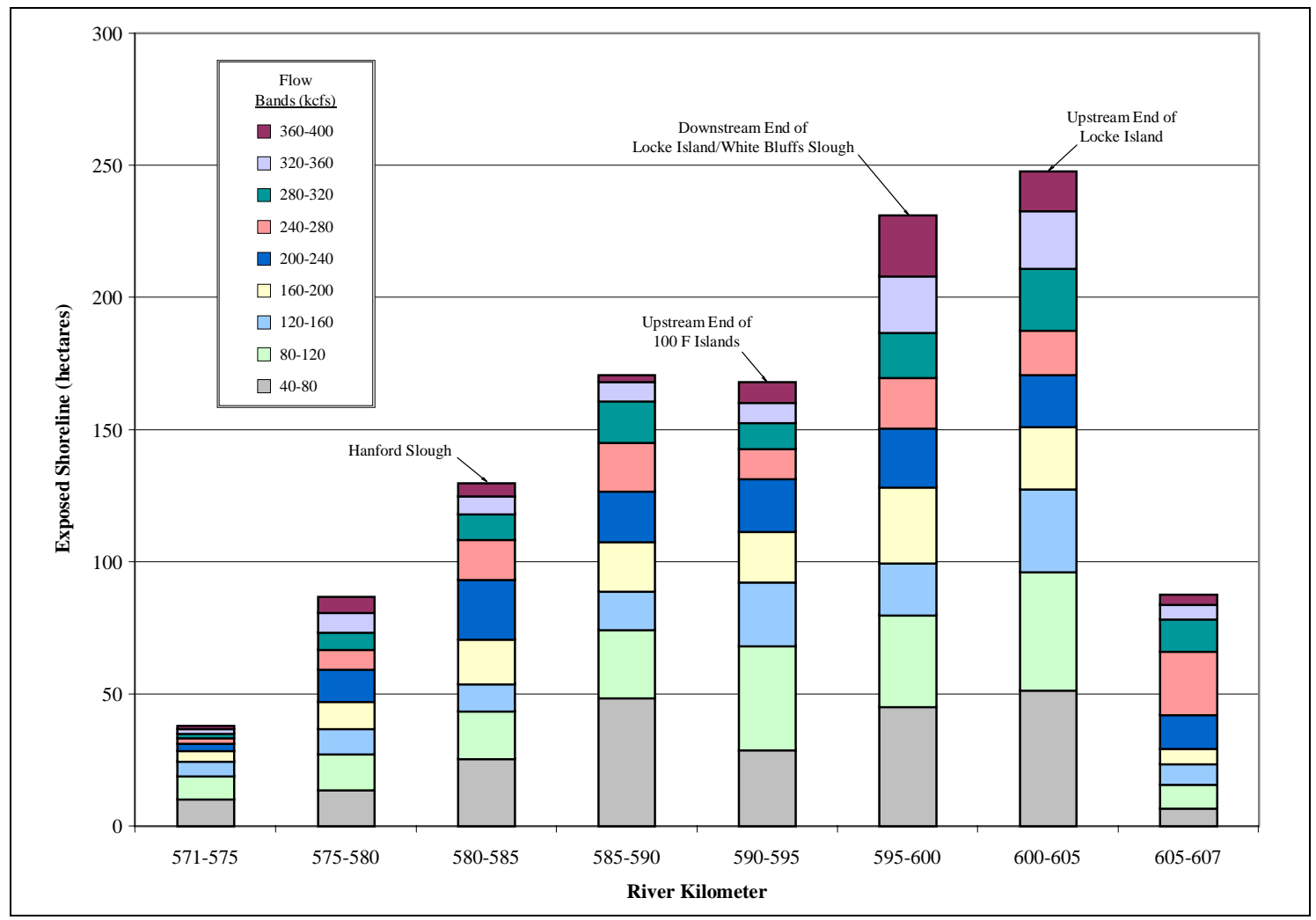

Figure 12. The area of shoreline exposed within $40 \mathrm{kcfs}$ flow band for five kilometer sections of the Hanford Reach of the Columbia River defined by the SHOALS data (Rkm 571.3 to Rkm 606.9). 

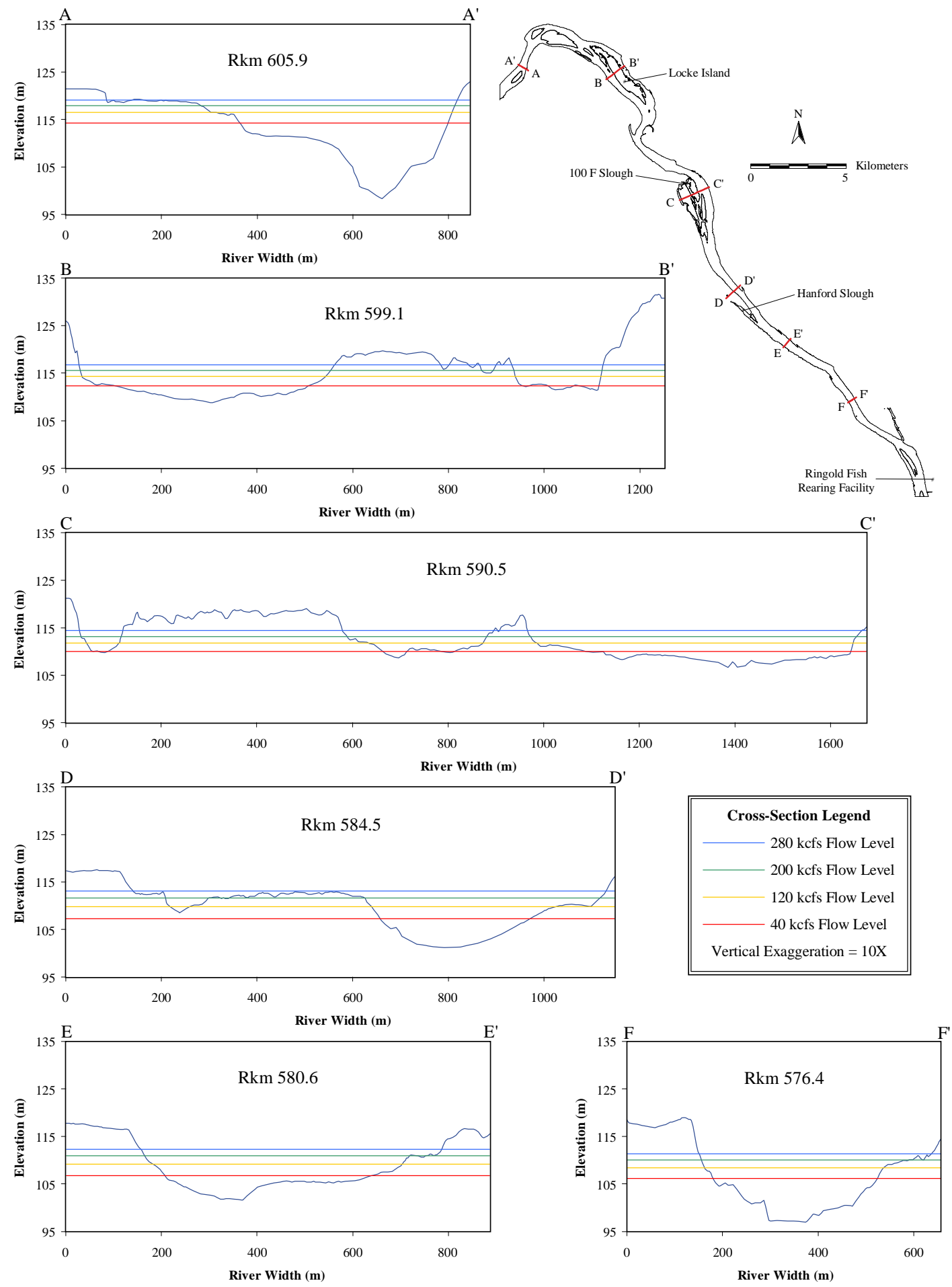

Figure 13. Cross-sectional views of the Hanford Reach of the Columbia River for the portion of the river defined by the SHOALS data (Rkm 571.3 to Rkm 606.9). 


\title{
Estimates of Juvenile Fall Chinook Salmon Stranding and Entrapment
}

\author{
Numbers of Juvenile Fall Chinook Salmon
}

A total of 950 random plots encompassing $187,961 \mathrm{~m}^{2}\left(2,023,261 \mathrm{ft}^{2}\right)$ were sampled in 1999 between March 19 and June 30 in six $40 \mathrm{kcfs}$ flow bands (40-80 kcfs, 80-120 kcfs, 120-160 kcfs, 160-200 kcfs, and 200-240 kcfs, and 240-280 kcfs). Of these, 766 were used to calculate loss estimates. One hundred and eighty four of the sample plots were not used. Sixteen of the samples were excluded because they were collected outside of the SHOALS area and 7 samples were excluded due to insufficient samples in the two respective flow bands (40-80 $\mathrm{kcfs}$ and 240-280 kcfs). A decision was made to only include samples through the week ending June 13 . This decision which eliminated 161 samples was made because no juvenile fall chinook salmon were found at risk after June 12 although the 1999 Hanford Reach Juvenile Fall Chinook Salmon Interim Protection Program and associated field sampling activities continued through June 30.

Random plots contained 1,026 juvenile fall chinook salmon in 1999 including 119 stranded and 907 entrapped individuals. Field crews recorded 222 direct mortalities consisting of the 119 stranded and 103 thermal induced fatalities (Table 3). Fish were first encountered in random plots on March 20 and last found on June 12. The majority of juvenile fall chinook salmon were sampled during the weeks of March 21-27, April 4-10, April 1117, and May 23-29. These time periods coincided with lower flows (<120 kcfs) and large flow fluctuations (>80 kcfs) (Figure 8).

The estimated total number of juvenile fall chinook salmon stranding and entrapment mortalities within the SHOALS defined study area (Rkm 571.3 to Rkm 606.9) in 1999 was calculated to be 125,695 with a $95 \%$ confidence interval between 50,724 and 200,666. Juvenile fall chinook salmon placed at risk of mortality due to stranding and entrapment was calculated to be 381,897 with a $95 \%$ confidence interval between -347 and 764,141 (Appendix C). It is obvious the lower limit of the 95\% confidence interval calculated using the standard error does not have physical meaning. A more reasonable lower limit would be 1,026, the number of fish found in the sampling surveys.

These assessments should be considered minimum estimates. The SHOALS defined study area is only a portion of the Hanford Reach and sampling efficiency was assumed to be $100 \%$. Potential sources of reduced sampling efficiency included losses of fish from sample locations to scavengers/predators prior to sampling and/or less than $100 \%$ efficiency in recovery of fish by surveyors during sampling activities.

Table 3. Weekly numbers of juvenile fall chinook salmon found in random plots on the Hanford Reach of the Columbia River in 1999.

\begin{tabular}{|c|c|c|c|c|}
\hline Week & Stranded $^{1}$ & Entrapped $^{2}$ & $\begin{array}{c}\text { Total Mortalities } \\
\text { (Stranded + Thermal) }\end{array}$ & $\begin{array}{c}\text { Total Chinook } \\
\text { at Risk } \\
\end{array}$ \\
\hline March 14-20 & 1 & 0 & 1 & 1 \\
\hline March 21-27 & 2 & 40 & 2 & 42 \\
\hline March 28-April 3 & 4 & 0 & 4 & 4 \\
\hline April 4-10 & 30 & 5 & 30 & 35 \\
\hline April 11-17 & 40 & $51(9)$ & 49 & 91 \\
\hline April 18-24 & 7 & 0 & 7 & 7 \\
\hline April 25-May 1 & 0 & 2 & 0 & 2 \\
\hline May 2-8 & 14 & 0 & 14 & 14 \\
\hline May 9-15 & 14 & 0 & 14 & 14 \\
\hline May $16-22$ & 3 & 2 & 3 & 5 \\
\hline May 23-29 & 0 & $789(83)$ & 83 & 789 \\
\hline May 30-June 5 & 0 & $3(1)$ & 1 & 3 \\
\hline June 6-12 & 4 & $15(10)$ & 14 & 19 \\
\hline June 13-19 & 0 & 0 & 0 & 0 \\
\hline June $20-26$ & 0 & 0 & 0 & 0 \\
\hline June 27-July 3 & 0 & 0 & 0 & 0 \\
\hline Total & 119 & $907(103)$ & 222 & 1,026 \\
\hline
\end{tabular}

\footnotetext{
${ }^{1}$ All stranded fish were counted as mortalities.
}

${ }^{2}$ Numbers in ( ) represent thermal mortalities. 
Juvenile fall chinook salmon collected in random plots had a mean fork length of $45.6 \mathrm{~mm}$ and ranged from 36 to $66 \mathrm{~mm}$ (Figure 14). Indivduals less than $60 \mathrm{~mm}$ comprised 96.9\% of the juvenile fall chinook salmon measured.

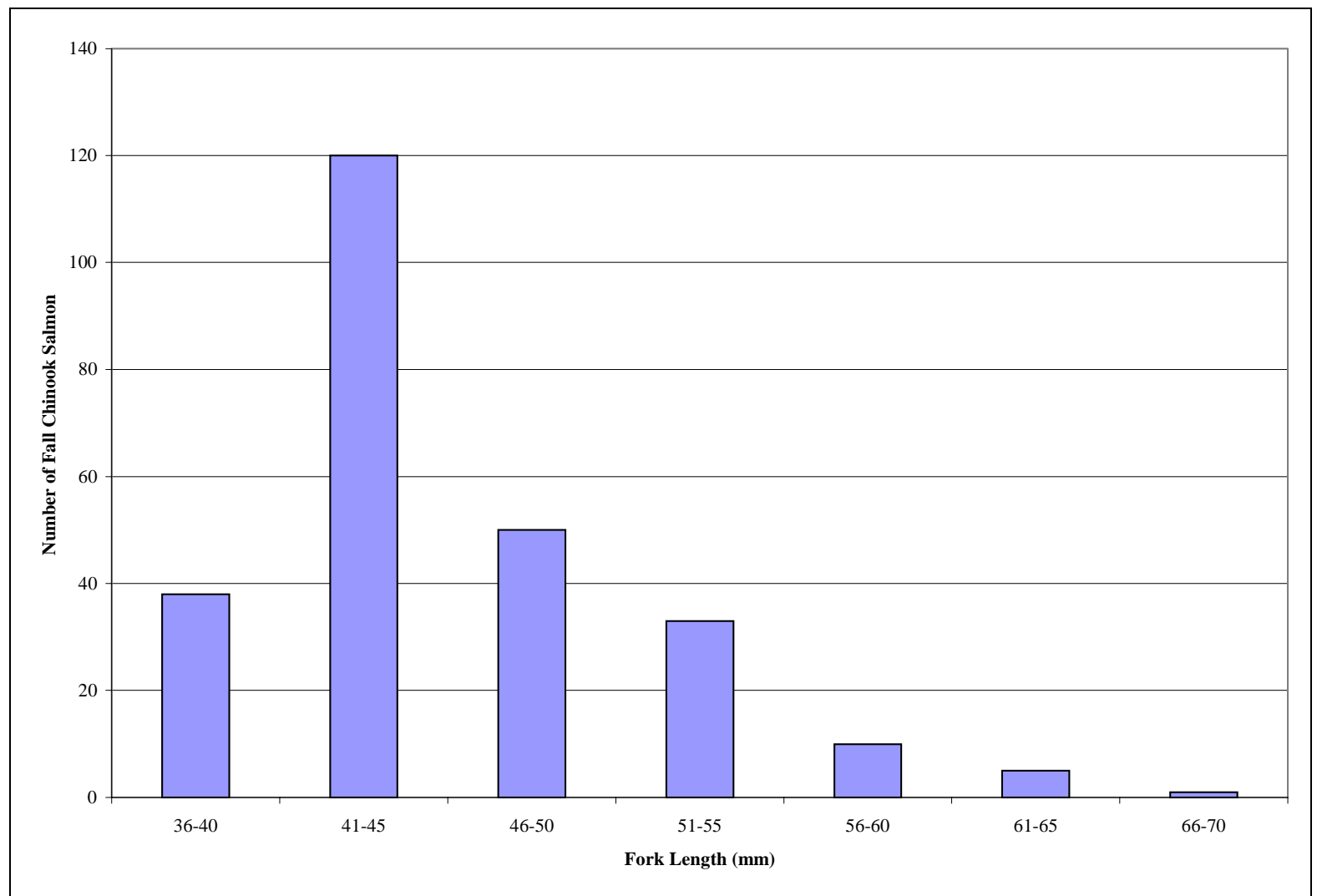

Figure 14. Fork length measurements of juvenile fall chinook salmon collected from random plots on the Hanford Reach of the Columbia River in 1999.

\section{Distribution of Juvenile Fall Chinook Salmon}

The portion of the Hanford Reach defined by the SHOALS bathymetry data was divided into eight river sections ( $\sim 5 \mathrm{Rkm}$ long) and the total amount of shoreline exposed during the entire juvenile fall chinook salmon emergence and rearing period was calculated for each $40 \mathrm{kcfs}$ flow band within each section to determine the horizontal and vertical distribution of stranding and entrapment (Figure 15). The total amount of shoreline exposed was calculated by multiplying the amount of shoreline exposed for each flow band at each river section by the number of flow fluctuations that occurred in that flow band over the entire period. The number of flow fluctuations was counted at Rkm 588.3, the closest MASS1 transect to the midpoint of the SHOALS data. Juvenile fall chinook salmon were found throughout the SHOALS defined study area at a variety of flow bands but the highest concentrations were found at the island complex areas of Locke Island (600-605 Rkm) and 100 F Islands (590-595 Rkm) at flows of 80-120 and 120-160 kcfs. 


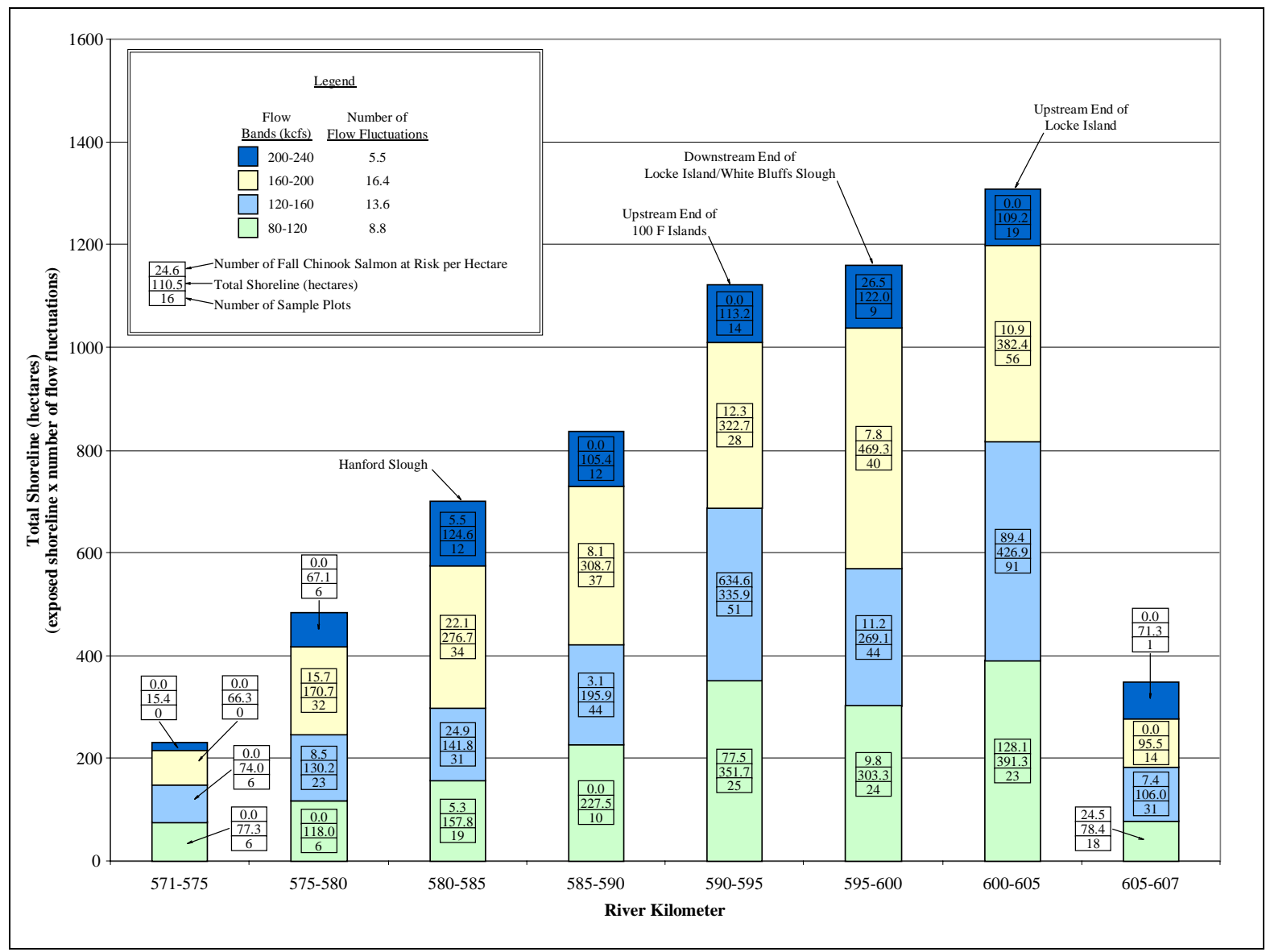

Figure 15. The total area of shoreline exposed during the 1999 juvenile fall chinook salmon emergence and rearing period within $\mathbf{4 0} \mathrm{kcfs}$ flow band for five kilometer sections of the Hanford Reach of the Columbia River defined by the SHOALS data (Rkm 571.3 to $\mathbf{R k m} 606.9)$. Included in the figure is the number of random plots sampled and the number juvenile fall chinook salmon found per hectare.

\section{Physical Characteristics of Random Sample Plots}

Substrate size, substrate embeddedness, and vegetation density in random plots varied between flow bands (Figure 16) and between river sections (Figure 17). Lower flow bands held more random plots containing gravel to cobble substrates with less substrate embeddedness and absent to medium vegetation density. Higher flow bands contained more random plots with finer substrates, higher substrate embeddedness and higher vegetation density. Juvenile fall chinook salmon were found in random plots with a range of physical characteristics but were most often found at lower flow bands in random plots with gravel to cobble substrates, low substrate embeddedness, and absent to medium vegetation density (Figure 18). The majority of juvenile fall chinook salmon were located in the two sections of the river in random plots that possessed these characteristics. The river sections included Rkm 600-605 (upstream end of Locke Island) and Rkm 590-595 (upstream end of $100 \mathrm{~F}$ Islands) (Figure 19). 


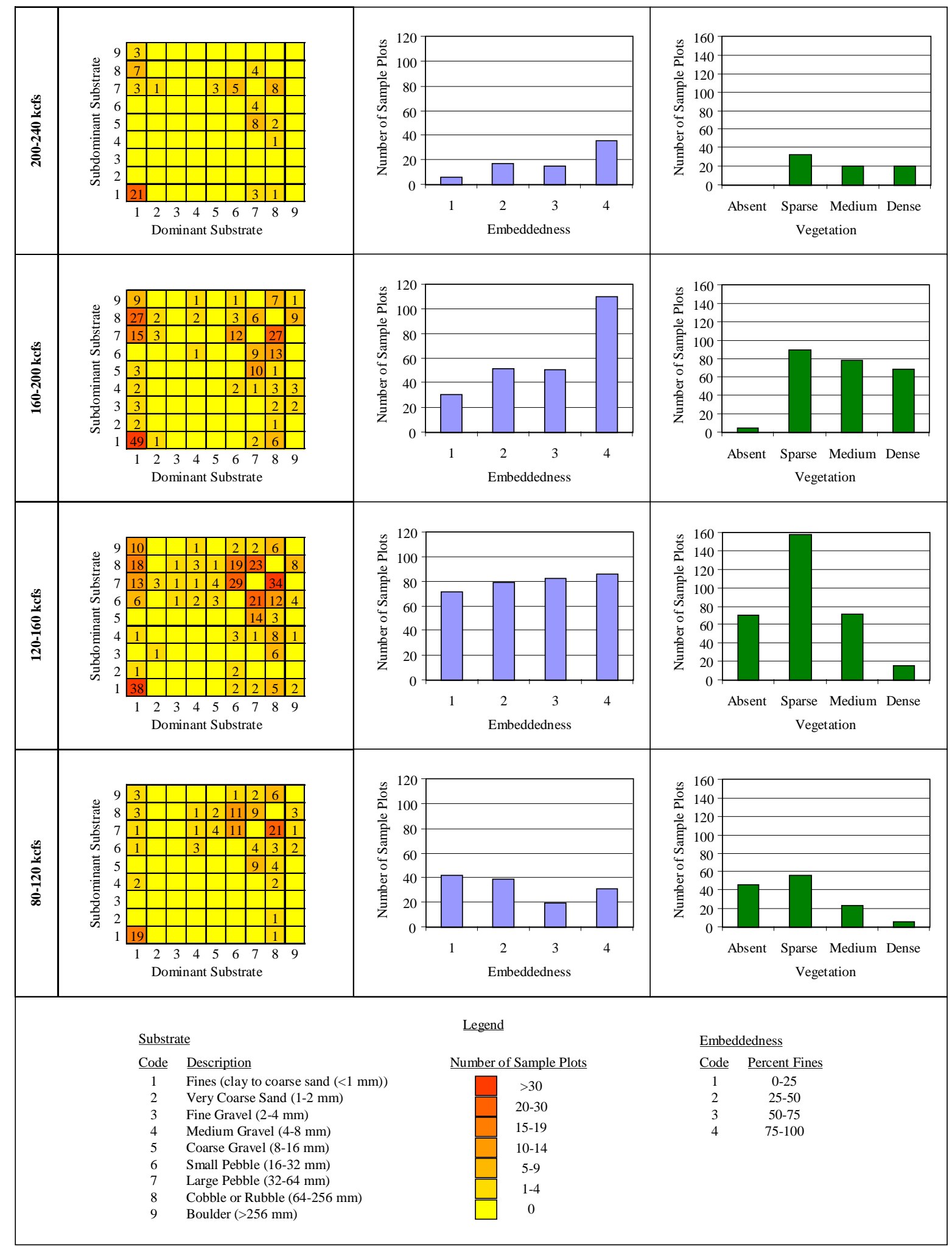

Figure 16. Comparison of substrate size, substrate embeddedness, and vegetation density of random plots between 40 kefs flow bands on the Hanford Reach of the Columbia River in 1999. 


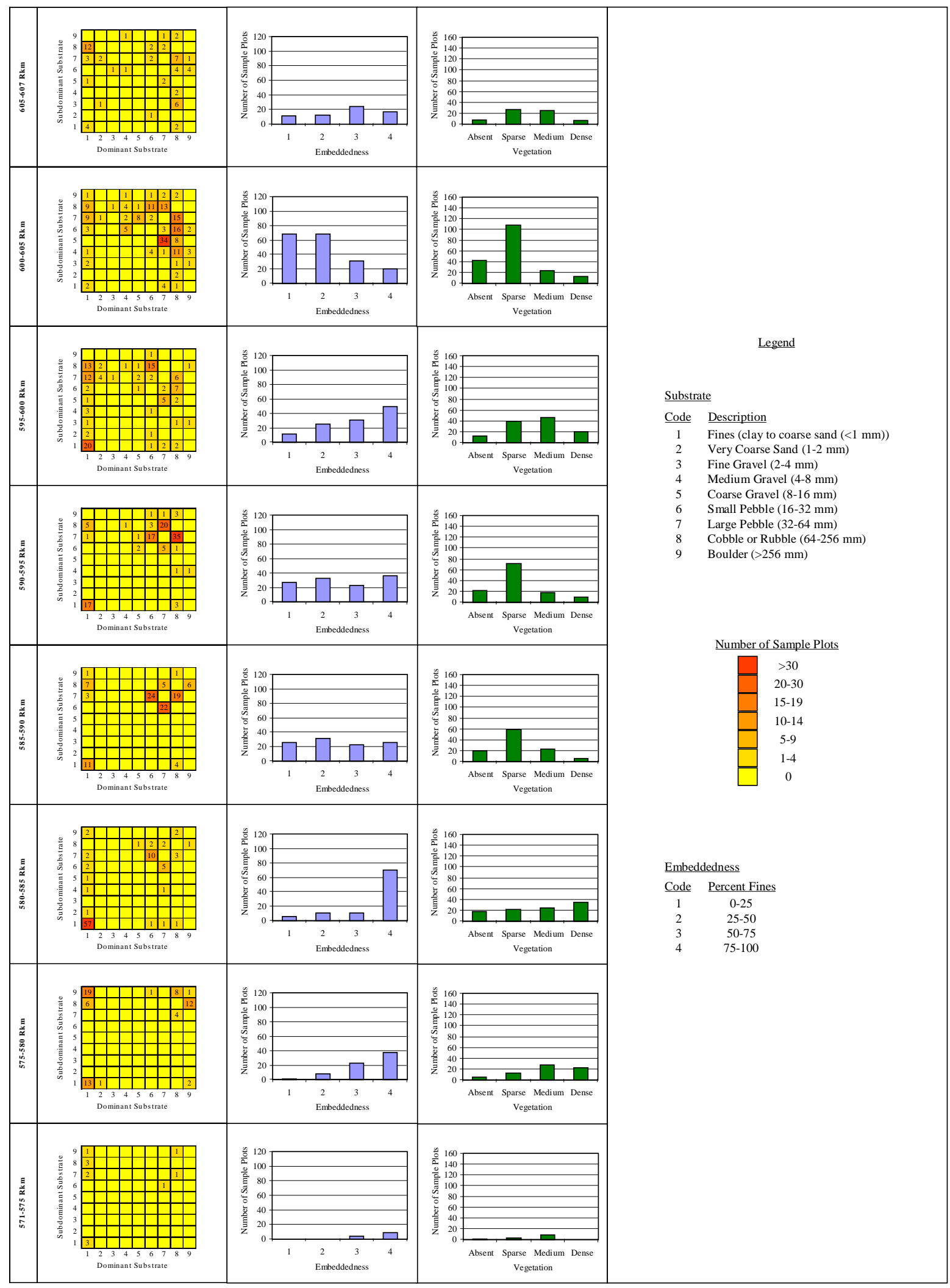

Figure 17. Comparison of substrate size, substrate embeddedness, and vegetation density of random plots between river sections on the Hanford Reach of the Columbia River in 1999. 


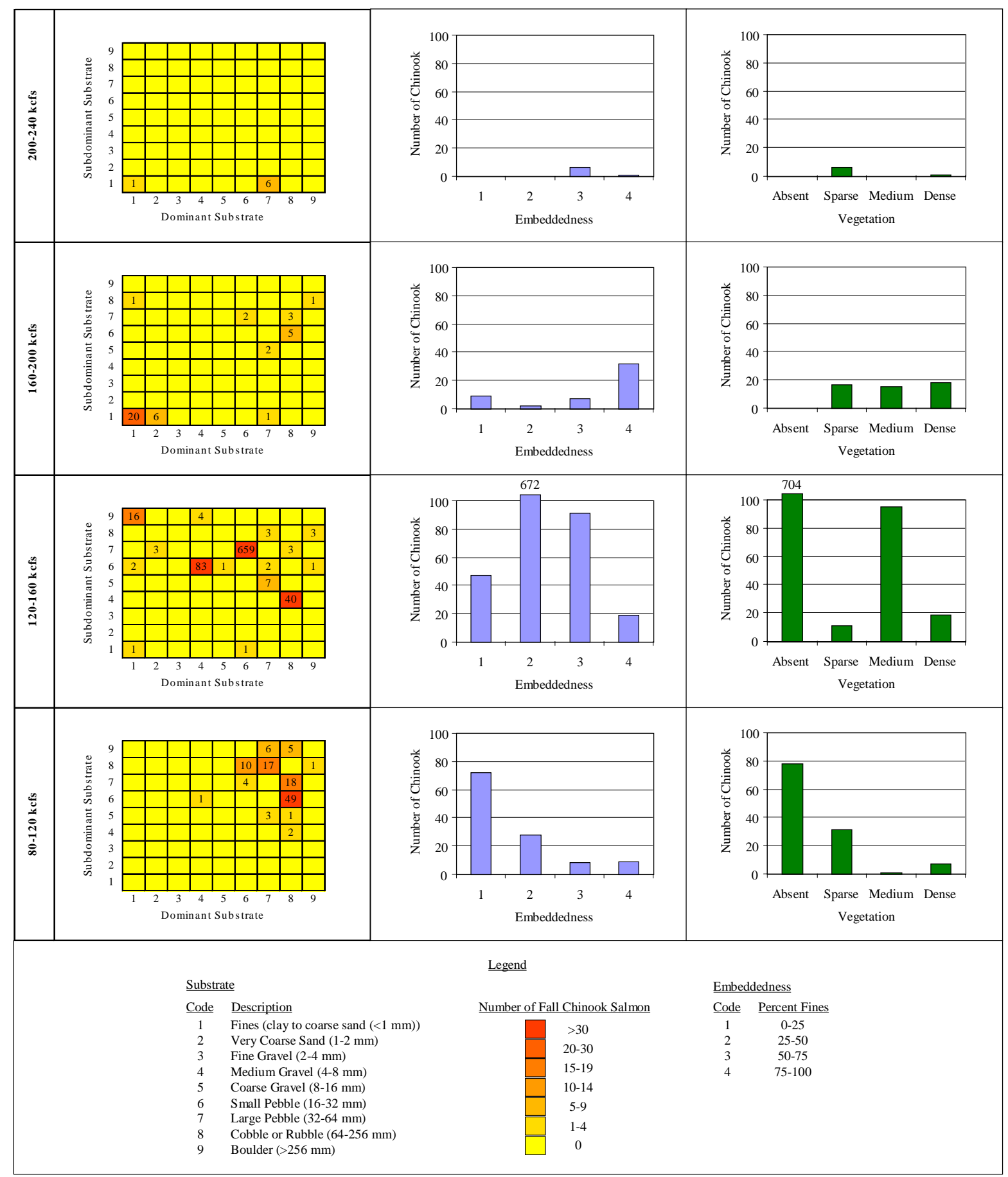

Figure 18. Comparison of numbers of stranded and entrapped juvenile fall chinook salmon and substrate size, substrate embeddedness, and vegetation density of random plots between $40 \mathrm{kcfs}$ flow bands on the Hanford Reach of the Columbia River in 1999. 


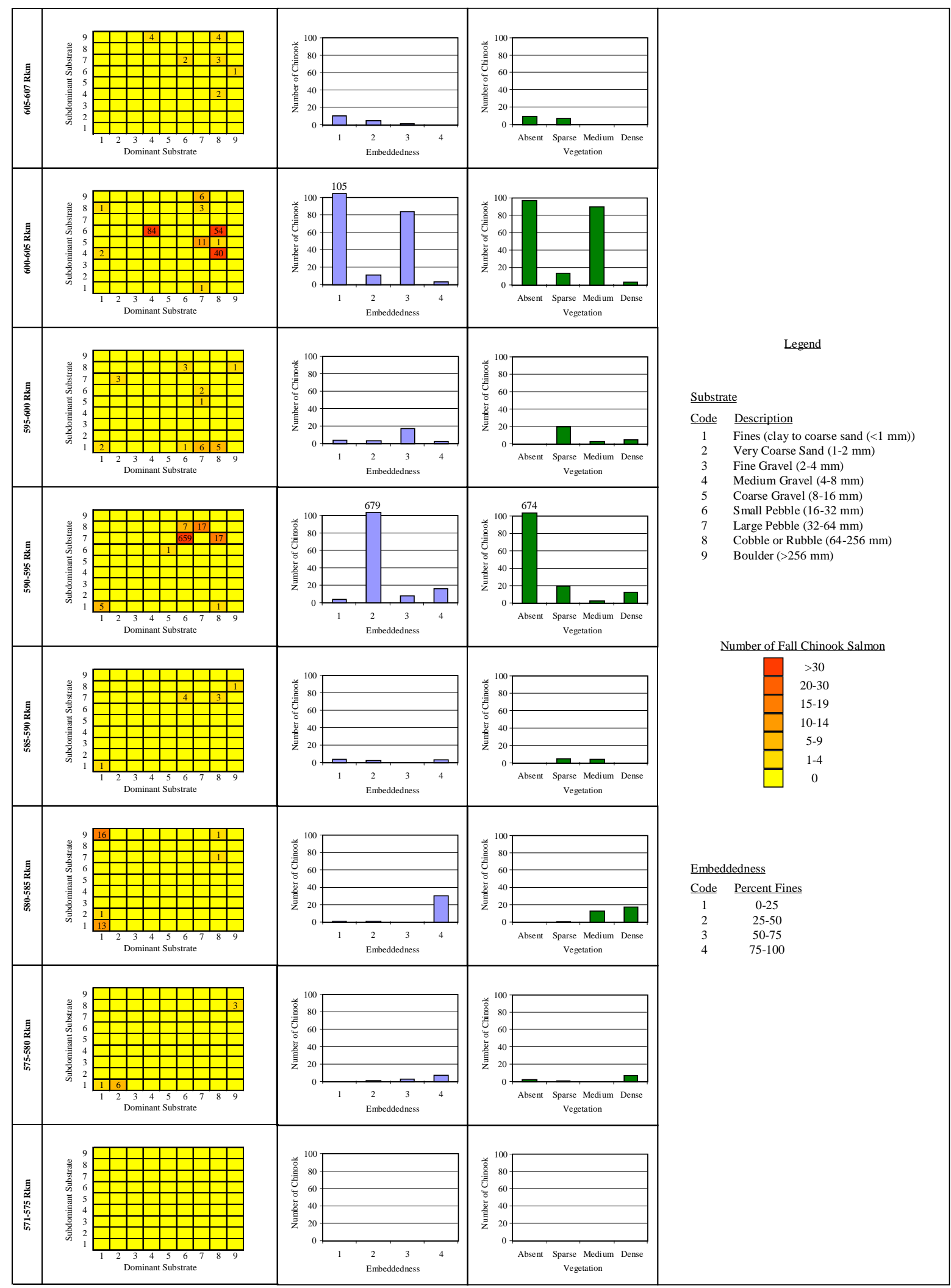

Figure 19. Comparison of numbers of stranded and entrapped juvenile fall chinook salmon and substrate size, substrate embeddedness, and vegetation density of random plots between river sections on the Hanford Reach of the Columbia River in 1999. 


\section{Fall Chinook Salmon Fry Production Estimate}

An estimated 8,405,936 fall chinook salmon fry were produced on the Hanford Reach in 1999 (Table 4). The Hanford Reach fall chinook salmon escapement estimate for 1998 was 35,393 adults (Watson. 1999). This total included 5,983 jacks which were removed from the calculation because jacks are generally all males and do not contribute to egg production. Based on sport harvest data, 582 of 1255 (46.4\%) fall chinook salmon caught on the Hanford Reach in 1998 were female (Appendix D). The average fecundity rate for fall chinook salmon at Priest Rapids Hatchery in 1999 was 4,200 eggs per female (Carlson 1999). Egg retention of natural spawners on the Hanford Reach is typically near zero as was the case in 1999 (Watson 1999). Egg to emergence/fry/smolt mortality rates used in this estimate were based on studies in the Nanaimo River, BC (Healey 1980), Fall Creek, CA (Wales and Coots 1954), and Cowichan River, BC (Lister et al. 1971) where mortality rates averaged 84,85 , and $87 \%$, respectively. Fry estimates could be as high as $17,193,960$ (30\% survival) if conditions in the Hanford Reach were favorable.

Table 4. Calculation of the $\mathbf{1 9 9 9}$ fall chinook salmon fry production estimate for the Hanford Reach of the Columbia River.

\begin{tabular}{|c|c|c|}
\hline Component & & Source \\
\hline 1998 Adult Fall Chinook Salmon Escapement & 29,410 & Hanford Reach Carcass and Creel Surveys, Watson 1999 \\
\hline Percent Females & 46.4 & Hanford Reach Sport Fishery, Unpublished \\
\hline Fecundity (Eggs per Female) & 4,200 & Priest Rapids Hatchery, Carlson 1999 \\
\hline Number of Spawning Females & 13,646 & \\
\hline Potential Eggs & $57,313,200$ & \\
\hline Egg Retention & 0 & Hanford Reach Carcass and Creel Surveys, Watson 1999 \\
\hline Total Eggs Deposited & $57,313,200$ & \\
\hline Estimated Mortality: & $9,170,112$ & Nanaimo, BC; Healy 1980 \\
\hline \multirow[t]{3}{*}{ Egg to Emergence/Fry/Smolt } & $8,596,980$ & Fall Creek, CA; Wales and Coots 1954 \\
\hline & $7,450,716$ & Cowichan River; Lister et al. 1971 \\
\hline & $8,405,936$ & \\
\hline
\end{tabular}

\section{Assessment of Juvenile Fall Chinook Salmon Relative Abundance and Fork Length}

Sampling to assess juvenile fall chinook salmon abundance and fork length began on March 5, just prior to the estimated start of emergence on March 8 (Carlson 1999), and ended on July 21 (Figure 20). A total of 7,388 juvenile fall chinook salmon were seined during this period. Juvenile fall chinook salmon were collected in every weekly sample but abundance was highest during the period from April 28 to June 2. Peak abundance occurred during the week of May 13 when 1,853 individuals were sampled.

Some juvenile fall chinook salmon collected on the Hanford Reach possessed ventral slits (unbuttoned), a physical characteristic of the late stage of yolk sac absorption in newly emergent fry. Fork lengths of these unbuttoned fall chinook salmon ranged up to $44 \mathrm{~mm}$ but were most often at or below $42 \mathrm{~mm}$. Juvenile fall chinook salmon with fork lengths at or below $42 \mathrm{~mm}$ comprised $30 \%$ or more of the fish sampled each week through May 26 and fish of this size remained in the samples until after June 22. Juvenile fall chinook salmon with fork lengths greater than $59 \mathrm{~mm}$, the size threshold that individuals are thought to become less susceptible to entrapment (Nugent et al. 2001), began to appear in the samples on May 5 but were not collected in considerable numbers until June 2. Priest Rapids Hatchery released 6,504,800 sub-yearling fall chinook salmon from June 14 to June 23 which resulted in an increase in the number and size of fish collected on the Hanford Reach at that time. 


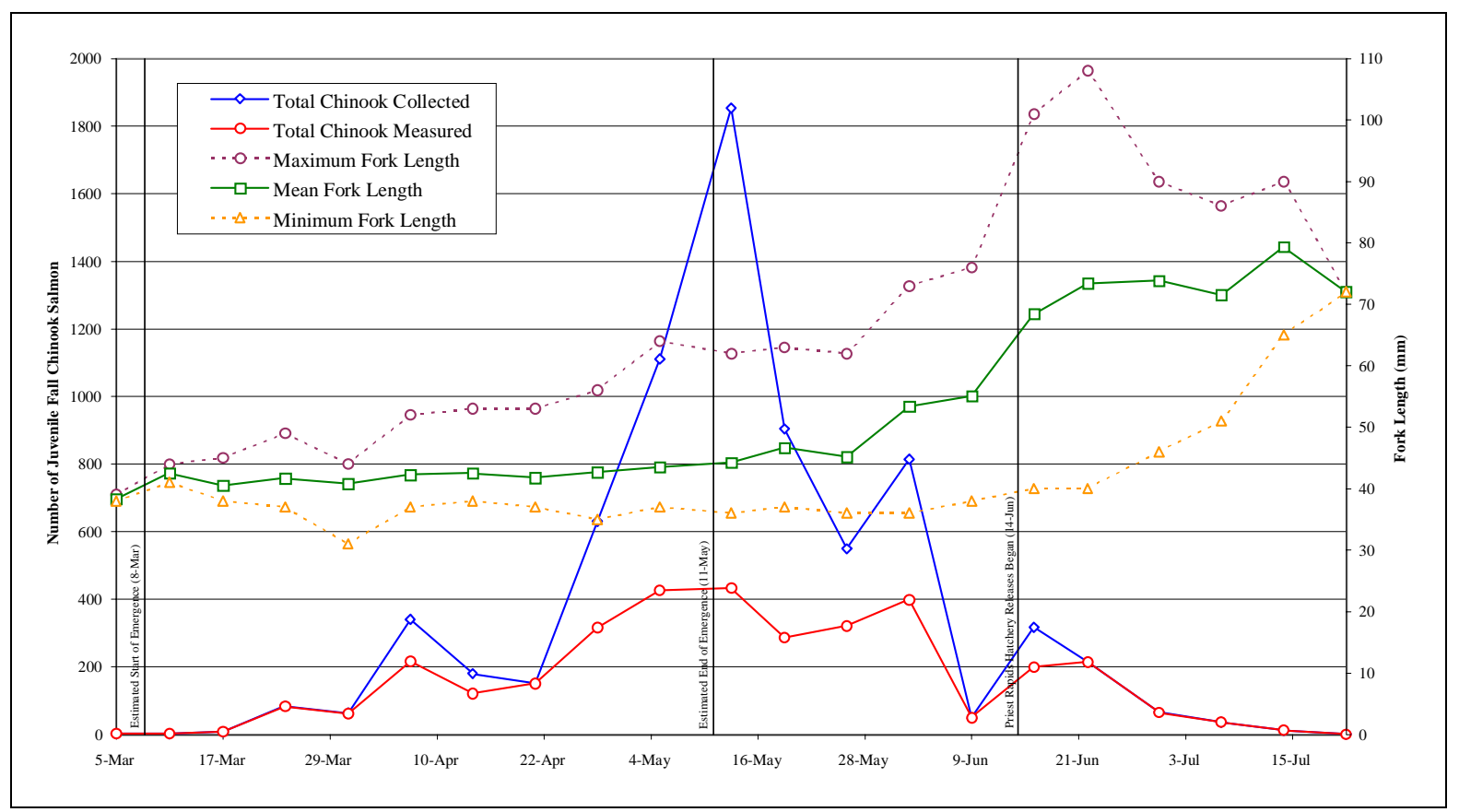

Figure 20. Relative abundance and fork length measurements of juvenile fall chinook salmon collected from nearshore sites on the Hanford Reach of the Columbia River in 1999.

\section{Evaluation of Potential Mortality Events in Primary Fall Chinook Salmon Rearing Areas}

The EMT monitored entrapments in primary fall chinook salmon rearing areas from April 17 to June 21 . A total of 8,241 juvenile fall chinook salmon were seined from 119 entrapments (including many of the same entrapments sampled on multiple days) during this time period (Table 5). Field crews recorded 166 direct mortalities at the time entrapments were sampled. Projected mortalites were estimated at 428 based on drainage or lethal temperatures monitored in entrapments. Criteria for emergency action were reached on four days (April 17, May 18, May 22, and May 23). GCPUD provided additional water to re-inundate (or increase river elevations) entrapments on each of these occurrences except May 22. On May 22, GCPUD reported that additional water was unavailable because project inflows were decreasing and active storage had already been used to avoid a sharp decrease in Priest Rapids Dam discharge.

Table 5. Weekly numbers of juvenile fall chinook salmon found by emergency management teams in primary rearing areas on the Hanford Reach of the Columbia River in 1999.

\begin{tabular}{|ccccc|}
\hline Week & $\begin{array}{c}\text { Number of } \\
\text { Entrapments }\end{array}$ & $\begin{array}{c}\text { Total Number } \\
\text { of Chinook }\end{array}$ & $\begin{array}{c}\text { Chinook Mortalities } \\
\text { at Time of Sampling }\end{array}$ & $\begin{array}{c}\text { Projected } \\
\text { Chinook Mortalities }\end{array}$ \\
\hline April 11-17 & 6 & 1,082 & 9 & 42 \\
April 18-24 & 17 & 5,145 & 127 & 127 \\
April 25-May 1 & 4 & 9 & 0 & 0 \\
May 2-8 & 5 & 23 & 0 & 0 \\
May 9-15 & 15 & 512 & 15 & 20 \\
May 16-22 & 16 & 765 & 8 & 95 \\
May 23-29 & 22 & 672 & 7 & 0 \\
May 30-June 5 & 6 & 0 & 0 & 0 \\
June 6-12 & 7 & 31 & 0 & 0 \\
June 13-19 & 16 & 2 & 0 & 0 \\
June 20-26 & 5 & 0 & 0 & 428 \\
\hline Total & 119 & 8,241 & 166 & \\
\hline
\end{tabular}

${ }^{1}$ Projected chinook mortalities were based on if entrapments drained or reached lethal temperatures $\left(>24^{\circ} \mathrm{C}\right)$. 


\title{
Surveys of Other Fish Species
}

\author{
Spring and Early Summer
}

Minimum numbers of fish other than fall chinook salmon were sampled during the implementation and evaluation of the Interim Protection Program in 1999 (March 5-June 30). Spring chinook salmon (Oncorhynchus tshawytscha) and at least 12 other species of fish were collected in nearshore sites and random plots during the spring and early summer sampling period (Table 6). Anadromous species sampled included spring chinook salmon, coho salmon (Oncorhynchus kisutch), and lamprey. Yearling chinook salmon were distinguished from subyearling chinook based upon size and morphological characteristics. Spring chinook salmon naturally outmigrate during the second year of life as yearlings in the mid and upper Columbia and therefore most of the yearling chinook sampled were believed to be spring chinook. Resident species found consisted of bluegill (Lepomis macrochirus), chiselmouth (Acrocheilus alutaceus), mountain whitefish, northern pikemoinnow, peamouth, redside shiner, sculpin, smallmouth bass, sucker, and threespine stickleback. Spring chinook salmon, coho salmon, chiselmouth, peamouth, and redside shiner were not represented in random plots. Northern pikeminnow, stickleback, and unidentifiable fish larvae comprised the majority of fish found stranded and entrapped. Stranding of lamprey is of special interest and may merit future attention.

Table 6. Total number of fish other than fall chinook salmon sampled on the Hanford Reach of the Columbia River during the spring and early summer sampling period (March 5-June 30, 1999).

\begin{tabular}{|c|c|c|c|c|c|}
\hline Common Name & Scientific Name & Nearshore & Stranded $^{1}$ & Entrapped $^{2}$ & Total Fish \\
\hline Spring Chinook Salmon & Oncorhynchus tshawytscha & 33 & 0 & 0 & 33 \\
\hline Coho Salmon & Oncorhynchus kisutch & 1 & 0 & 0 & 1 \\
\hline Lamprey & Lampetra spp. & 0 & 3 & 0 & 3 \\
\hline Bluegill & Lepomis macrochirus & 0 & 0 & 3 & 3 \\
\hline Chiselmouth & Acrocheilus alutaceus & 1 & 0 & 0 & 1 \\
\hline Mountain Whitefish & Prosopium williamsoni & 150 & 0 & 4 & 154 \\
\hline Northern Pikeminnow & Ptychocheilus oregonensis & 41 & 3 & 204 & 248 \\
\hline Peamouth & Mylocheilus caurinus & 6 & 0 & 0 & 6 \\
\hline Redside Shiner & Richardsonius balteatus & 12 & 0 & 0 & 12 \\
\hline Sculpin & Cottus spp. & 6 & 5 & 0 & 11 \\
\hline Smallmouth Bass & Micropterus dolomieui & 1 & 0 & 4 & 5 \\
\hline Sucker & Catostomus spp. & 5 & 0 & 4 & 9 \\
\hline Threespine Stickleback & Gasterosteus aculeatus & 29 & 5 & 30 & 64 \\
\hline Unknown Juvenile & - & 1 & 0 & 0 & 1 \\
\hline Unknown Larvae & - & 0 & 0 & 102 & 102 \\
\hline Total & & 286 & 16 & 351 & 653 \\
\hline
\end{tabular}

${ }^{1}$ All stranded fish were counted as mortalities.

${ }^{2}$ No entrapped fish were found dead.

Summer and Early Fall

The summer and early fall sampling program began on July 1 and ended September 29. WDFW investigated 15 stranding and entrapment sites and performed weekly sampling of eight nearshore sites. Small numbers of eight resident fish species were found stranded and entrapped during this time period (Table 7). Species consisted of bluegill, dace, northern pikeminnow, peamouth, smallmouth bass, sucker, threespine sickleback, and walleye (Stizostedion vitreum). Nearshore samples collected during the summer and early fall were sent to USGS/BRD Columbia River Research Laboratory for analysis. Results of this analysis are not currently available but will be included in a report summarizing this work for the years 1998 through 2000. 
Table 7. Total number of fish sampled on the Hanford Reach of the Columbia River during the summer and early fall sampling period (July1-September 29, 1999).

\begin{tabular}{|llccc|}
\hline Common Name & Scientific Name & Stranded $^{1}$ & Entrapped $^{2}$ & Total Fish $^{\text {Bluegill }}$ \\
\hline Dace & Lepomis macrochirus & 0 & 3 & 3 \\
Northern Pikeminnow & Rhinichthys spp. & 0 & 1 & 1 \\
Peamouth & Mylochocheilus oregonensis & 0 & 4 & 4 \\
Smallmouth Bass & Micropterus dolomieui & 0 & 1 & 1 \\
Sucker & Catostomus spp. & 23 & 19 & 42 \\
Threespine Stickleback & Gasterosteus aculeatus & 4 & 5 & 9 \\
Walleye & Stizostedion vitreum & 3 & 2 & 5 \\
\hline Total & & 31 & 35 & 66 \\
\hline
\end{tabular}

${ }^{1}$ All stranded fish were counted as mortalities.

${ }^{2}$ No entrapped fish were found dead.

\section{Night Surveys of Predation on Stranded and Entrapped Juvenile Fall Chinook Salmon}

On May 5, WDFW crew members conducted the first of two pilot surveys to assess nocturnal bird predation on entrapped juvenile fall chinook salmon. Crew members arrived on Locke Island (Rkm 600.0) at approximately $2000 \mathrm{hrs}$. The flows began to drop at $0100 \mathrm{hrs}$ and continued to drop throughout the night. At $0300 \mathrm{hrs}$ the WDFW crew observed a number of juvenile fall chinook salmon in water less than one inch deep becoming separated from the river. These fish were lying torpid on the bottom and seemed to be unaware of the presence of the crew. Near sunrise at approximately $0400 \mathrm{hrs}$, the WDFW crew observed killdeer (Charadrius vociferous) near the edges of entrapments and great blue herons (Ardea herodias) flying and calling on nearby areas. Throughout the evening great blue herons were observed and heard. The birds were never seen feeding on juvenile fall chinook salmon.

The second night survey was conducted on May 15 in Hanford Slough (Rkm 585.0). The two WDFW crew members arrived at approximately $2030 \mathrm{hrs}$. Flows rose until approximately $0230 \mathrm{hrs}$ then began to fall. Juvenile fall chinook salmon were observed feeding until $2100 \mathrm{hrs}$. Two dead juvenile fall chinook salmon were observed floating in an entrapment as the water began to rise. There was no bird activity noted until approximately $0430 \mathrm{hrs}$ when two great egrets (Ardea alba) were observed feeding in flooded grass as the water began to recede.

\section{Evaluation of the Effects of Fluctuations on the Benthic Macroinvertebrate Community}

A complete description of the results of the benthic macroinvertebrate assessment are included in Appendix $\mathbf{E}$ and summarized here. Construction bricks and barbecue baskets containing concrete cones were test in 1998 to determine the optimal substrates for macroinvertebrate colonization. Marcoinvertebrates colonized both brick and barbecue basket artificial substrates at high densities during preliminary sampling in August and September 1998 , averaging 27,600 invertebrates $/ \mathrm{m}^{2}$. Benthic marcoinvertebrate fauna was low in diversity and dominated by Chironomidae (midges) and Trichoptera (caddisflies) larvae, comprising $87 \%$ of the community by density. Barbecue baskets colonized significantly higher density and biomass of benthic macroinvertebrates than brick artificial substrates. Brick artificial substrates colonized for 4 weeks were selected to assess effects of water level changes during year-2 (1999) sampling, because they most efficiently provided the needed precision.

Results from the long-term tests clearly show that benthic macroinvertebrates within the river fluctuation zone were severely limited in density and biomass compared to the communities on continually inundated areas. Total invertebrate density was approximately 4 times higher on bricks never dewatered than on substrates exposed only 1 to 24 hours. Mean total invertebrate density and biomass were reduced by $59 \%$ and $65 \%$, respectively, from substrates exposed up to 24 hours to substrates never dewatered. Midges were the only invertebrates that tolerated up to 24 hours of exposure to air during the 30-day period without declines, and comprised a higher proportion of the invertebrate community with longer durations of exposure to air. 
Substrates exposed during more than 361 hours of the test period experienced as much as a $99 \%$ reduction in total density and biomass relative to control substrates. Long-term results indicated that of the two primary taxa, caddisflies were affected more drastically than midges.

Drift movement of macroinvertebrates differed for the two primary taxa. Short-term drift samples revealed that midge drift densities increased with discharge and water level while caddisfly drift densities increased during periods of darkness. Changes in discharge and water levels catastrophically entrained macroinvertebrates into the drift outside of behavioral diel periodicity.

Effects of short-term exposure scenarios revealed that a dramatic decrease in survival was found with even short duration exposures to air. Artificial exposure tests revealed that survival of macroinvertebrates on substrates exposed to air decreased dramatically with increasing duration of exposure, with only $50 \%$ survival after 1 hour of exposure. A large proportion of invertebrates exposed to air quickly migrated to avoid desiccation, but smaller and less mobile early instars of midges incurred higher mortality.

Results of long-and short-term studies of dewatering on artificial substrates, indicate water level fluctuations affect nearshore community structure, density, and biomass of macroinvertebrates in the Hanford Reach.

\section{Investigation of Thermal Tolerance and Predation on Juvenile Fall Chinook Salmon}

Thermally-stressed fish showed little direct mortality and no increases in vulnerability to predation. However, these fish showed transient increases in plasma concentrations of cortisol, glucose, and lactate, and a dramatic (25-fold higher than controls) and persistent (lasting 2 weeks) increase in levels of liver hsp70. Although our results may suggest that such stressors pose no serious threat to these fish, we are concerned about other effects and types of thermal stressors not addressed in this study and perhaps more importantly, the consequences of exposure of fish to multiple, cumulative stressors. Detailed results are included in Appendix F.

\section{Conclusions}

\section{Juvenile Fall Chinook Salmon}

Upon emergence, juvenile fall chinook salmon swim or are displaced downstream (Healey 1998) and move to the margins of the river in areas of reduced current velocity (Dauble et al. 1989). From the time of emergence until they are approximately $60 \mathrm{~mm}$ in fork length, juvenile fall chinook salmon are shallow water obligates and are subject to flow fluctuations from Priest Rapids Dam. Consequently, fry are forced to move with the shifting shoreline and are found stranded and entrapped in a range of habitat types, flow bands, and river sections. However, some habitat types, flow bands, and river sections, whether selected for or not, seem to be more hazardous to stranding and entrapment than others. In 1999, juvenile fall chinook salmon were found stranded and entrapped most frequently at flows of 80-120 and 120-160 kcfs in areas with gravel to cobble substrates, low substrate embeddedness, and absent to medium vegetation density. Highest concentrations of juvenile fall chinook salmon were found at the island complex areas of Locke Island (Rkm 600-605) and $100 \mathrm{~F}$ Islands (Rkm 590-595). These island complex areas with their large and varied shorelines and diverse shallow water areas appear to provide excellent rearing habitat as well as high stranding and entrapment potential. Large flats or flood terraces are present in these areas at those flow levels. Flood terraces may also be a concern at other river sections and at other flow levels.

The estimated total number of juvenile fall chinook salmon mortalities and fish placed at risk of mortality due to stranding and entrapment appeared to be moderately low in 1999. Based on a fall chinook salmon fry production estimate of 8,405,936 for the Hanford Reach, an estimated 1.4\% (with 95\% confidence interval between 0.6 and $2.4 \%$ ) of the population died as a result of stranding or entrapment within the SHOALS defined study area (Rkm 571.3 to Rkm 606.9) and 4.5\% (with 95\% confidence interval between 0 and 9.1\%) of the population was placed at risk of mortality due to stranding and entrapment. It has been suggested that the SHOALS defined study area contains approximately half of the rearing fall chinook salmon habitat on the Hanford Reach. If this is true, the estimated losses for the entire Hanford Reach would be roughly double that of SHOALS defined study area. 


\section{Other Fish Species}

Low numbers of fish other than fall chinook salmon were found stranded and entrapped on the Hanford Reach in 1999. Eleven genera (a minimum of 11 species) were identified including northern pikeminnow, threespine stickleback, smallmouth bass, sculpin, mountain whitefish, sucker, bluegill, lamprey, peamouth, dace, and walleye. The stranding of lamprey in 1999 is of special interest because pacific lamprey (Lampetra tridentatus) and river lamprey (lampetra ayresi) are listed as federal species of concern and river lamprey are also designated as a Washington State candidate species. Impacts of flow fluctuations to lamprey would be difficult to assess since lamprey ammocoetes spend 4-6 years in mud as filter feeders before migrating to the ocean. Lamprey were also found stranded in 1998.

\section{Macroinvertebrates}

Reduction in the amplitude and/or frequency of flow fluctuations from hydropeaking operations of Priest Rapids dam will likely have substantial effects on the macroinvertebrate community in the Hanford Reach. Dampened flow fluctuations may allow some reestablishment of a native and more diverse marcoinvertebrate community. Reduced flow fluctuations, particularly during critical salmonid rearing periods, could potentially enhance invertebrate biomass. In addition, peaking discharges during nighttime hours would result in a more naturalized drift pattern and less desiccation due to lower air temperatures and evaporation than daytime fluctuations.

\section{Recommendations}

The joint fish managers, consisting of WDFW, the Columbia River Inter-Tribal Fish Commission, the Tribes of the Columbia River Basin, the Oregon Department of Fish and Wildlife, NMFS, and USFWS, continue to recommend that the best operational plan to reduce stranding and entrapment of juvenile fall chinook salmon on the Hanford Reach is for Priest Rapids Dam to create no fluctuations (flat loading) and/or steadily increasing flows throughout the emergence and rearing period. The power managers, consisting GCPUD, BPA, the United States Bureau of Reclamation, and the Mid-Columbia Public Utility Districts (Chelan and Douglas Counties), continue to maintain that this option is infeasible. Based on the low estimated loss of juvenile fall chinook salmon in 1999, the Hanford Policy Group recommended, with the exception of eliminating the rewetting of entrapment zones after large fluctuations, that the operation constraints imposed in 1999 should be repeated in 2000. The following operational constraints were recommended for the 2000 juvenile fall chinook salmon emergence and rearing period:

1) Limit flow fluctuations from Priest Rapids Dam to a range of $40 \mathrm{kcfs}$ on a daily basis (60 kcfs on a daily basis during flow augmentation for outmigrating juvenile fish under NMFS Biological Opinion) when weekly average flows are less than $170 \mathrm{kcfs}$ at Priest Rapids Dam

2) Restrict flows to an hourly minimum of $150 \mathrm{kcfs}$ when weekly average flows are greater than $170 \mathrm{kcfs}$ at Priest Rapids Dam.

These operational constraints will be imposed when a daily total of 50 or more subyearling fall chinook salmon are seined from the six established nearshore sampling sites used to assess relative abundance and fish size. The sampling of these sites will begin one week prior to the calculated start of emergence under the 1988 Vernita Bar Agreement. Seining will be conducted every other day to define the beginning of susceptibility then once a week thereafter. Operational constraints will be lifted when no more than a total of 50 subyearling fall chinook salmon less than $60 \mathrm{~mm}$ are captured in the six nearshore sampling sites or seining catch has declined to $4 \%$ or less of the cumulative annual total. 


\section{References}

Bauersfeld, K. 1978. Stranding of juvenile salmon by flow reductions at Mayfield Dam on the Cowlitz River, 1976. Technical Report No. 36. Washington Department of Fisheries.

Barfoot, C.A., D. M Gadomski, and R. H. Wertheimer. 1999. Growth and mortality of age-0 northern squawfish, Ptychocheilus oregonensis, rearing in shoreline habitats of a Columbia River reservoir.

Environmental Biology of Fishes 54:107-115.

Beck, R. W. 1989. Skagit River salmon and steelhead fry stranding studies. Prepared by R. W. Beck Associates for the Seattle City Light, Environmental Affairs Division, Seattle, Washington.

Becker, C. D., D. H. Fickeisen, and J. C. Montgomery. 1981. Assessment of impacts from water level fluctuations on fish in the Hanford Reach, Columbia River. PNL-3813. Pacific Northwest Laboratory. Richland, Washington.

Carlson, C. 1999. Draft Vernita Bar monitoring for 1998-1999. Public Utility District of Grant County. Annual Report.

Dauble, D. D., T. L. Page, and R. W. Hanf, Jr. 1989. Spatial distribution of juvenile salmonids in the Hanford Reach, Columbia River. Fishery Bulletin 87(4):775-790.

Dauble, D. D. Annual chinook salmon redd counts, 1991, 1994, 1995. Battelle Pacific Northwest Laboratory, Richland, Washington.

Dauble, D. D., and D. G. Watson. 1997. Status of fall chinook salmon populations in the Mid-Columbia River, 1948-1992. North American Journal of Fisheries Management 17(2):283-300.

DeVore, J. 1988. Evidence of stranding of zero-age wild fall chinook on the Hanford Reach of the Columbia River. Memorandum to Don McIsaac date June 9, 1988. Washington Department of Fisheries.

Geist, D. 1989. Stranding of zero-age wild fall chinook on the Hanford Reach of the Columbia River. Memorandum to Phil Peterson dated August 7, 1989. Washington Department of Fisheries.

Glantz, C. S., M. N. Schwartz, K. W. Burk, R. B. Kasper, M. W. Ligotke, and P. J. Perrault. 1990 Climatological summary of wind and temperature data for the Hanford meteorology monitoring network. PNL7471. Pacific Northwest Laboratory, Richland, Washington.

Hanford Meteorological Station. 1999. http://etd.pnl.gov:2080/HMS. Access date September 4, 2000.

Healey, M. C. 1980. Utilization of the Nanaimo River estuary by juvenile chinook salmon, Oncorhynchus tshawytscha. Fish. Bull. (U.S.) 77:653-668.

Healey, M. C. 1998. Life history of chinook. In Pacific salmon life histories. C. Groot and L. Margolis, eds. pp. 311-394. UBC Press, Vancouver, British Columbia.

Huntington, C. S., W. Nehlsen, and J. Bowers. 1996. A Survey of healthy native stocks of anadromous salmonids in the Pacific Northwest and California. Fisheries 21(3):6-14.

Key, L. O., J. A. Jackson, C. R. Sprague, and E. E. Kofoot. 1994. Nearshore habitat use by subyearling chinook salmon in the Columbia and Snake rivers. In Identification of the spawning, rearing and migratory requirements of fall chinook salmon in the Columbia River Basin. D. W. Rondorf and W. H. Miller, eds. pp. 120-150. Annual Report to Bonneville Power Administration, Contract DE-AI7991BP21708, Portland, Oregon. 
Lister, D. B., C. E. Walker, and M. A. Giles. 1971. Cowichan River chinook salmonescapements and juvenile production 1965-1967. Fish. Serv. (Can.) Pac. Reg. Tech. Rep. 1971-3:8 p.

Mason, W. T., Jr., and P. P. Yevich. 1967. The use of phloxine B and rose bengal stains to facilitate sorting benthic samples. Transactions of the American Microscopic Society 86(2):221-223.

Nugent, J., T. Newsome, M. Nugent, W. Brock, P. Wagner, and L. Key. 2001. 1998 Evaluation of juvenile fall chinook salmon stranding on the Hanford Reach of the Columbia River. Prepared for The Bonneville Power Administration and the Public Utility District Number 2 of Grant County. BPA Contract Number 97BI30417 and GCPUD Contracts Document 430-647.

Ocker, P. A. 1996. Observations of salmonid strandings in the Hanford Reach. Memorandum to Paul Wagner dated September 17, 1996. U.S. Fish and Wildlife Service.

Page, T. L. 1976. Observations on juvenile salmon stranding in the Columbia River, April 1976. Report of Battelle Pacific Northwest Laboratories to United Engineers and Contractors for Washington Public Water Supply System, Richland, Washington.

Phinney, L. A. 1974a. Further observations on juvenile salmon stranding in the Skagit River, March 1973. Washington Department of Fisheries.

Phinney, L. A. 1974b. Report on the 1972 study of the effect of river flow fluctuations below Merwin Dam on downstream migrant salmon. Washington Department of Fisheries.

Platts, W. S., W. F. Megaham, and H. W. Minshall. 1983. Methods for evaluating stream, riparian, and biotic conditions. U.S. Forest Service, General Technical Report INT-138, Intermountain Forest and Range Experiment Station, Ogden, Utah.

Rickard, W. H. 1988. Climate of the Hanford Site. In Shrub-steppe: balance and change in a semi-arid terrestrial ecosystem. Developments in agricultural and managed-forest ecology 20. W. H. Rickard, L. E. Rogers, B.E. Vaughan, and S. F.Liebetrau, eds. pp. 13-21. Elsevier, New York.

Richmond, M. C. and W .A. Perkins. 1998. Draft MASS1 Modular Aquatic Simulation System 1D A one dimensional hydrodynamic and water quality model for river systems. Pacific Northwest Laboratory, Richland, Washington.

Thompson, J. S. 1970. Skagit River fry mortality study, March 1969. Washington Department of Fisheries.

Tipping, J., P. Buckley, and J. Danielson. 1978. Cowlitz River steelhead spawning and fry stranding study, 1977-78. Progress Report. Washington Department of Game.

Tipping, J., S. Springer, P. Buckley, and J. Danielson. 1979. Cowlitz River steelhead spawning, fry emergence and stranding, 1977-79, and adult life history study, 1977-79. Washington Department of Game.

United States Geological Survey Gauging Station \# 12472800 Below Priest Rapids Dam 1989-1998. http://www.cqs.washington.edu/dart/headwater_calm.html. Access Date July 24, 2001.

Wagner, P. G. 1995. May 14, 1995 Observations of trapped and stranded fall chinook fry near the Vernita Bridge. Memorandum to W. Dammers dated May 16, 1995. Washington Department of Fish and Wildlife.

Wagner, P., J. Nugent, W. Price, R. Tudor, and P. Hoffarth. 1999. 1997-99 Evaluation of juvenile fall chinook stranding on the Hanford Reach. 1997 Interim Report. Prepared for The Bonneville Power Administration and the Public Utility District Number 2 of Grant County. BPA Contract Number 97BI30417 and GCPUD Contracts Document 430-647. 
Wales, J. H., and M. Coots. 1954. Efficiency of chinook salmon spawning in Fall Creek, California. Trans. Am. Fish. Soc. 84:137-149.

Watson, R. 1999. 1998 Hanford Reach fall chinook stream survey summary. Pacific States Marine Fisheries Commission.

White, R. G., A. E. Bingham, J. H. Milligan, M. A. Brusven, and C. A. Corraino. 1985. Effects of reduced stream discharge on fish and aquatic macroinvertebrate populations phase II. Research Technical Completion Report. Idaho Water Resources Research Institute, University of Idaho, Moscow.

Witty, K. and K. Thompson. 1974. Fish stranding surveys. In: Anatomy of a river. K. Bayha and C. Koski eds. pp. 113-120. Pacific Northwest River Basins Commission, Vancouver, Washington.

Woodin, R. 1984. Evaluation of salmon fry stranding induced by fluctuating hydroelectric discharge in the Skagit River, 1980-83. Technical Report No. 83. Washington Department of Fisheries. 
Appendix A

1999 Hanford Reach Juvenile Fall Chinook Protection Program 


\section{Hanford Reach Juvenile Fall Chinook Protection Program \\ April 9, 1999}

The criteria for development of this program as proposed by the seven mid-Columbia hydroelectric projects are:

1. Substantially higher protection in 1999 than 1998;

2. Maintain reasonable load following capability at all 7 projects;

3. Monitoring and evaluation that allows evaluation of the program relative to its effect on entrapment and stranding; and

4. A monitoring program that allows in-season changes of operations if substantial mortality is detected.

\section{When PRD average weekly discharge is greater than $170 \mathrm{kcfs}$ ?}

1. When average weekly discharge at Priest Rapids is greater than $170 \mathrm{kcfs}$, the mid-

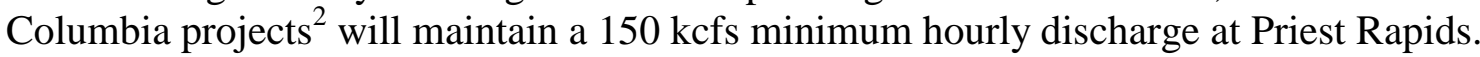

2. In addition, mid-Columbia projects will provide a re-wetting regime ${ }^{\text {Z }}$ up to the lesser of Friday's peak discharge or 200 kcfs on weekends when Priest Rapids weekend discharge is less than the weekly average.

3. Minimum flows will be maintained for no longer than 8 hours.

\section{When PRD average weekly discharge is less than or equal to $170 \mathrm{kcfs}:$}

1. For the peried starting when stranding susceptibility begins until implementation of BO flow targets ${ }^{4}$ (approx. April 10):

A. Within the requirements of flood control, project operating constraints, and the BO, the GCL weekly average discharge will steadily increase.

B. The mid-Columbia projects will limit flow fluctuations below Priest Rapids to no more than $+20 \mathrm{kcfs}$ and $-20 \mathrm{kcfs}$ on a daily basis. In addition, midColumbia projects will provide a re-wetting regime on weekends when Priest Rapids weekend discharge is less than the weekly average.

\footnotetext{
${ }^{1}$ Under existing non-power constraints, average weekly discharge at Priest Rapids is expected to remain above $170 \mathrm{kcfs}$ from mid-April until late-June.

${ }^{2}$ The term “mid-Columbia projects", wherever used, includes Priest Rapids, Wanapum, Rock Island, Rocky

Reach, Wells, Chief Joseph, and Grand Coulee dams operated under the hourly coordination agreement.

${ }^{3}$ Re-wetting is defined as meeting Friday's peak discharge for 4 hours with minimum flows maintained for no longer than 8 hours. This operation is repeated every 12 hours during Saturdays and Sundays.

${ }^{4}$ PRD flows are expected to be less than $170 \mathrm{kcfs}$ during this period.

${ }^{5,6}$ Except when the upper limit results in an upper limit flow greater than $150 \mathrm{kcfs}$, there will be no upper limit.
} 
2. For the period from implementation of BO flow targets (April 10) until the end of stranding susceptibility:

A. Within the requirements of flood control, project operating requirements, and the BO, GCL will operate to produce average weekly flows of at least 135 kcfs at Priest Rapids.

B. The mid-Columbia projects will limit flow fluctuations below Priest Rapids to no more than $+30 \mathrm{kcfs}$ and $-30 \mathrm{kcfs}$ on a daily basis when the fish spill program is in effect at Priest Rapids. When fish spill is not occurring, flow fluctuations will be limited to no more than $+20 \mathrm{kcfs}$ and $-20 \mathrm{kcfs}$ on a daily basis. ${ }^{6}$ In addition, the mid-Columbia projects will provide a re-wetting regime on weekends when Priest Rapids weekend discharge is less than the weekly average.

3. Minimum flows will be maintained for no longer than 8 hours.

\section{Monitoring, Evaluation and Adaptive Management}

1. Until stranding susceptibility ends, a weekly report for the Monday through Sunday time period (e.g. March 15 through March 21) will be produced by Grant County PUD and the WDFW. This report will be available on the Technical Management Team (TMT) website at the following URL

$<$ www.npd-wc.usace.army.mil/cgi-bin/proposal.cgi?type=index

and will be presented at the weekly TMT meetings. This report will also be distributed to the Hanford Reach Stranding Policy Group each Monday afternoon by e-mail. The TMT will serve as a forum for information exchange and will not be involved in decisionmaking under this Program. It is anticipated that TMT decisions will facilitate, support and not impede activities under this Program. The authority for implementing any changes under this Program rests with the mid-Columbia projects and any disputes will be handled through meetings of the Hanford Reach Stranding Policy Group.

A. This report will include the following operational information for each day: minimum hourly discharge from Priest Rapids Dam (PRD), maximum hourly discharge from PRD, day average discharge at PRD and whether or not fish spill was occurring. The report will also provide weekly average discharge at PRD.

B. The weekly reports will also include the following field monitoring information for each day: number of samples taken, number of stranded or entrapped chinook fry and number of chinook mortalities. The weekly report will also include the number of chinook fry sampled from standard index sites which will be used to determine when susceptibility to stranding and entrapment ends. 
2. If high levels of chinook entrapment likely to result in mortality are observed, the midColumbia operators will evaluate whether to implement operational changes to reduce the level of mortality. At the weekly TMT meeting, the mid-Columbia operators will explain the problem and propose operational changes to resolve it. If there are no significant objections from the Hanford Reach Stranding Policy Group, the operator's proposal will be implemented as soon as practicable.

3. If high levels of chinook entrapment likely to result in mortality are observed and there is significant objection to the mid-Columbia operators' proposal to resolve the problem, the Hanford Reach Stranding Policy Group will meet or hold a conference call within 3 days to resolve the conflict.

4. If the field monitoring crew observe that a significant fall chinook mortality event is occurring or imminent, they will immediately notify the designated representative of the Washington Department of Fish and Wildlife (WDFW) and explain the situation. The WDFW representative will confirm whether a significant fall chinook mortality event is occurring or imminent and decide whether to request a modification of operations. If alteration of operations appears appropriate, the WDFW representative will notify Grant County PUD immediately to discuss a remedy. If Grant County PUD concurs that a significant fall chinook mortality event is occurring or imminent, it will consult, as necessary, with other operators and an operational remedy will be implemented expeditiously. 7

5. An e-mail explaining the event and describing the remedy taken will be sent to the Hanford Reach Stranding Policy Group by Grant County PUD no later than the next business day following the event.

\footnotetext{
${ }^{7}$ It is anticipated that the parties involved will implement this process in no more than a few hours from initial notification to implementation of remedy, day or night.
} 


\section{Program Modification No. 1}

Date: $\quad$ April 14, 1999

To: $\quad$ Hanford Reach Stranding Policy Group

From: $\quad$ Doug Ancona, Grant County PUD

Subject: $\quad$ Modification to 1999 Hanford Reach Juvenile Fall Chinook Protection Program (Program)

On April 14, 1999 a conference call of the Hanford Reach Stranding Policy Group (Policy Group) was held to discuss the weekend operations of April 10 and 11. Several members of the Policy Group raised concerns about the effectiveness of the weekend re-wetting operation with respect to the size and number of fluctuations on April 10 and 11, 1999. These concerns focused on the potential for these fluctuations to have negative effects on juvenile fall chinook as emergence progresses and air and water temperatures increase. To address these concerns, it was suggested that the Program be modified by deleting the weekend rewetting regime. There was no significant objection to this proposal. Accordingly, the 1999 Hanford Reach Juvenile Fall Chinook Protection Program is modified as follows, effective noon April 16, 1999 and thereafter unless changed.

\section{When PRD average weekly discharge is less than or equal to $170 \mathrm{kcfs}$ :}

1. For the period starting when stranding susceptibility begins until implementation of $\mathrm{BO}$ flow targets (approx. April 10):

A. Within the requirements of flood control, project operating constraints, and the $\mathrm{BO}$, the GCL weekly average discharge will steadily increase.

B. The mid-Columbia projects will limit flow fluctuations below Priest Rapids to no more than +20 kcfs and -20 kcfs on a daily basis

2. For the period from implementation of BO flow targets (April 10) until the end of stranding suscepti-bility:

A. Within the requirements of flood control, project operating requirements, and the BO, GCL will operate to produce average weekly flows of at least $135 \mathrm{kcfs}$ at Priest Rapids.

B. The mid-Columbia projects will limit flow fluctuations below Priest Rapids to no more than $+30 \mathrm{kcfs}$ and $-30 \mathrm{kcfs}$ on a daily basis when the fish spill program is in effect at Priest Rapids. When fish spill is not occurring, flow fluctuations will be limited to no more than $+20 \mathrm{kcfs}$ and $-20 \mathrm{kcfs}$ on a daily basis.

All other aspects of the program remain unchanged. 


\section{Program Modification No. 2}

Date: $\quad$ April 21, 1999

To: $\quad$ Hanford Reach Stranding Policy Group

From: Doug Ancona, Grant County PUD

Subject: Modification No. 2 to 1999 Hanford Reach Juvenile Fall Chinook Protection Program Hanford Reach Flows For the Time Period April 22-25, 1999

The operators have discussed Hanford Reach operations for the time period of April 22 through April 25 and produced the following targets for Priest Rapids discharge based on inflow information provided by BPA:

\begin{tabular}{|ll|l|l|l|}
\hline Date & Day Average Flow & Minimum Flow & Maximum Flow \\
\hline April 22 & Thurs & 140 & 115 & 155 \\
\hline April 23 & Fri & 140 & 115 & 155 \\
\hline April 24 & Sat & 135 & 110 & 150 \\
\hline April 25 & Sun & 125 & 110 & 150 \\
\hline
\end{tabular}

This operation will be accomplished through drafting of Wanapum and Priest Rapids reservoirs and through cooperation with upstream operators. BPA has also agreed to provide its best efforts to keep the reduction in weekday to weekend discharge to no more than $10 \%$. Flow fluctuations below Priest Rapids will be limited to no more than $+20 \mathrm{kcfs}$ and $-20 \mathrm{kcfs}$ on a daily basis for the specified period.

Please keep in mind the variety of competing constraints that must be met and that these numbers are targets. Actual operations may deviate from these targets but the operators will make every attempt to keep any deviations to a minimum. 


\section{Program Modification No. 3}

Date: $\quad$ April 23, 1999

To: $\quad$ Hanford Reach Stranding Policy Group

From: $\quad$ Doug Ancona, Grant County PUD

Subject: $\quad$ Modification No. 3 to 1999 Hanford Reach Juvenile Fall Chinook Protection Program Hanford Reach Flows For the Time Period April 23-25, 1999

The operators have discussed Hanford Reach operations for the time period of April 23 through April 25 and produced the following targets for Priest Rapids discharge based on inflow information provided by BPA:

\begin{tabular}{|ll|l|l|l|}
\hline Date & Day Average Inflow & Minimum Outflow & Maximum Outflow \\
\hline April 22 & Thurs & 163 Actual & 159 Actual & 183 Actual \\
\hline April 23 & Fri & 156 & 150 & 190 \\
\hline April 24 & Sat & 150 & 150 & 190 \\
\hline April 25 & Sun & 150 & 150 & 190 \\
\hline
\end{tabular}

This operation will be accomplished through drafting of Wanapum and Priest Rapids reservoirs and through cooperation with upstream operators. BPA has also agreed to provide its best efforts to keep the reduction in weekday to weekend discharge to no more than $10 \%$. Flow fluctuations below Priest Rapids will be limited to no more than $+20 \mathrm{kcfs}$ and $-20 \mathrm{kcfs}$ on a daily basis for the specified period.

Please keep in mind the variety of competing constraints that must be met and that these numbers are targets. Actual operations may deviate from these targets but the operators will make every attempt to keep any deviations to a minimum. 


\section{Appendix B}

Substrate Size, Substrate Embeddedness, and Vegetation Codes 


\title{
Substrate Codes
}

Dominant substrate is most common to the sample area and subdominant is the next most common substrate class.

\begin{tabular}{c} 
Code \\
\hline 1 \\
2 \\
3 \\
4 \\
5 \\
6 \\
7 \\
8 \\
9
\end{tabular}

\author{
Substrate class \\ Fines (clay to coarse sand $(<1 \mathrm{~mm}))$ \\ Very coarse sand (1-2 $\mathrm{mm})$ \\ Fine gravel (2-4 mm) \\ Medium gravel (4-8 mm) \\ Coarse gravel (8-16 mm) \\ Small pebble (16-32 $\mathrm{mm})$ \\ Large pebble (32-64 mm) \\ Cobble or rubble (64-256 mm) \\ Boulder (>256 mm)
}

\section{Substrate Embeddedness Codes}

The substrate embeddedness is estimated visually. Substrate embeddedness refers to the degree that the interstices between the larger particles are filled by sand, silt or clay.

$\begin{array}{cc}\frac{\text { Code }}{1} & \frac{\text { \% Fines }}{0-25} \\ 2 & 25-50 \\ 3 & 50-75 \\ 4 & 75-100\end{array}$

\section{$\underline{\text { Description }}$}

Openings between dominant sized particles are $1 / 3$ to $1 / 2$ the size of the particles. Few fines in between. Edges are clearly discernable.

Openings are apparent but $<1 / 4$ the size of the particles. Edges are discernable but up to half obscured.

Openings are completely filled but half of edges are still discernable.

All openings are obscured. Only one or two edges discernable and size cannot be determined without removal.

\section{Vegetation Codes}

Vegetation is assessed visually to estimate the percent of ground coverage.

$\begin{array}{ll}\text { Code } & \text { Description } \\ & \text { No vegetation present. } \\ 2 & \text { Sparse vegetation, substrate is completely evident. } \\ 3 & \text { Medium vegetation, substrate is only partially obscured. } \\ 4 & \begin{array}{l}\text { Dense vegetation, substrate is nearly or completely obscured by the } \\ \text { vegetation. }\end{array}\end{array}$




\section{Appendix C}

Estimation of Total Number of Dead Chinook Caused by Stranding 


\section{Estimation of Total Number of Dead Chinook Caused by Stranding}

The total number of salmon mortalities due to stranding was estimated for a portion of the Hanford Reach during the sampling period from March 19 to June 13. The estimate was based on 766 sample measurements taken in four flow bands of the Hanford Reach: 80-120, 120-160, 160-200, and 200-240 thousand cubic feet per second (kcfs). The samples were collected randomly within each flow band within the area in which the SHOALS topographic/bathymetric data was available. As such, the estimate is only representative of a portion of the entire Hanford Reach, and must be considered a minimum estimate. The four flow bands that were sampled in the study area can be considered as four strata, so estimation of the total number of trapped salmon was performed using a stratified random sampling algorithm.

The number of samples used in the estimate is smaller than the total number of samples taken during the sampling campaign (950). Sixteen samples were excluded because they fell just outside the area of the SHOALS data, or in areas where the SHOALS data was incorrect due to the presence of shrubbery or other noise. In either case, it was not possible to identify the flow bands with which the 16 samples were associated. An additional 7 samples were not included because they were taken in flow bands where there were not enough samples available to estimate the impact within the flow bands ( 5 samples were taken in the 40-80 and 2 samples in the 240-280 kcfs flow bands). This occurred because the number of flow fluctuations that affected those bands was extremely small, relative to the other flow bands, so the overall impact due to fluctuations impacting those flow bands is minimal. Finally, a decision was made to only include samples collected through the end of the week ending June $13^{\text {th }}$. This decision, which eliminated an additional 162 samples from the estimate, was made because no chinook were found to be at risk after June $12^{\text {th }}$ by the random sampling effort.

A sampling plan was designed prior to the field season that identified all potential sampling locations in the study area and determined which flow band they fell in using the SHOALS data and the MASS1 flow model. The sample size used in the study was approximately $3600 \mathrm{sq} \mathrm{ft}$. Samples were then selected randomly from the population of potential samples within each flow band, with the number of random samples selected being proportional to the size of the flow band. A list of random samples, with location coordinates and the flow band to which they belonged, was provided to the Washington Department of Fish and Wildlife. Each morning, the flow band to target for sampling was identified based on the flow fluctuations in the previous $12 \mathrm{hr}$ period. A list of samples would then be drawn from the list of random samples for sampling that day. Each sampling crew would use a high-resolution global positioning system (GPS) to navigate to the sample locations on the days' list. An anchor weight was placed at the center of each sample plot, and a rope was used to determine the boundary of the circular sampling plot. In many cases, the entire area of the plot could not be sampled, because portions of the plot were still under water at the rivers edge, or were above the wetted shoreline. In those cases, a sketch was made that was later used to estimate the proportion of the plot that could actually be sampled. The number of chinook at risk within the sample plot due to stranding was counted, as well as the number of chinook that were dead, or were likely to die due to stranding in an entrapment (i.e., due to high temperature or imminent drainage of the entrapment). Other data were also recorded, including the substrate type. 
The first step in the calculation of the total number of dead chinook was to calculate the number of dead salmon per sample plot. If the entire plot could not be sampled, then the number of chinook that would be found in a full size sample plot was estimated by dividing the number of chinook found by the proportion of the plot sampled to the standard plot size. The average number of chinook per plot in each flow band, $\bar{x}_{h}$, was calculated as the sample mean of the number of trapped salmon for all samples collected within a flow band $h$, where samples are denoted as $\mathrm{x}_{\mathrm{hi}}$, with $h=1,2,3,4$ and $i=1 \ldots \mathrm{n}_{\mathrm{h}}$. Here $h$ is the index of the flow band and $n_{h}$ is the number of samples taken within a flow band $h$. The equation for estimating the stratified average number of dead salmon per sample plot is:

$$
\bar{x}_{s t}=\sum_{h=1}^{4} W_{h} \bar{x}_{h}
$$

where $W_{h}$ is the weight of a flow band $h$. The weights for each flow band are found by calculating the total number of plots in a flow band, $N_{h}$, and dividing by the total number of potentially impacted plots in all four flow bands. Note that $N_{h}$ also accounts for the number of fluctuations of flow over the area of a flow band $h$, that is, the total number of potentially impacted plots $N_{h}$ is the number of plots in a flow band $h$ multiplied by the number of fluctuations affecting that flow band (see Table 1). In equation $1, \bar{x}_{h}$ is the sample mean of the number of trapped salmon per sample plot within a flow band $h$.

The number of fluctuations occurring during the study period in each of the 4 flow bands was counted by WDFW personnel using hourly discharge data from Priest Rapids Dam that had been processed by the MASS1 model. The processing was done to account for attenuation of the amplitude of the fluctuations in the river flows as recorded at the project as the flows move down through the Hanford Reach, which causes a reduction in the number of fluctuations that would be counted at areas downstream of the project. Model calculations were performed using MASS1 to examine the difference between the number of fluctuations at the top and bottom of the study area, as well as for three intermediate cross-sections within the study area. The model calculations were performed for 5 cross-sections that were approximately evenly-spaced within the SHOALS study area. For the estimate, the decision was made to use the number of fluctuations calculated for the middle cross-section in the study area (Transect \#85), which was nearly equal to the average number of fluctuations for the 5 cross-sections. The numbers of fluctuations found for each of the 4 flow bands used in the estimate (80-120, 120-160, 160-200, and 200-240 kcfs) are 9.3, 13.6, 16.4, and 5.5, respectively.

The unbiased estimate of the variance of the stratified average $\left(\operatorname{Var}\left(\bar{x}_{s t}\right)\right)$ is estimated by the weighted sample variance using Eq.[2]:

$$
s^{2}\left(\bar{x}_{s t}\right)=\sum_{h=1}^{4} W_{h}^{2} \frac{s_{h}^{2}}{n_{h}}
$$

where the variance of the number of dead chinook per sample plot for each flow band is calculated by

$$
s_{h}^{2}=\frac{1}{n_{h}} \sum_{i=1}^{n_{h}}\left(x_{h i}-\bar{x}_{h}\right)^{2}
$$

The total number of dead salmon, $\hat{I}$, over the entire area of the four flow bands is estimated by Eq.[4]: 


$$
\hat{I}=\sum_{h=1}^{4} N_{h} \bar{x}_{h}=N \bar{x}_{s t}
$$

The estimate of the variance of $\hat{I}$ is obtained from Eq.[5]:

$$
s^{2}(\hat{I})=N^{2} s^{2}\left(\bar{x}_{s t}\right)
$$

The $95 \%$ confidence interval of the estimated total number of salmon mortalities is determined by Eq.[6]:

$$
\hat{I} \pm 1.96 * s(\hat{I})
$$

assuming a normal distribution.

The data used in computation of the number of salmon mortalities due to stranding are listed in the following table. The estimate for the total number of chinook that died within the study area during the period from March 19 - June 13 is 125,695, and a 95\% confidence interval for that estimate is $[50,724,200,666]$. This estimate is a minimum estimate, because the random sampling program only sampled a portion of the Hanford Reach, and we had to assume $100 \%$ efficiency during the sampling, i.e., that no dead chinook were missed during the sampling of each random plot.

\section{Chris Murray}

Yi-Ju Chien

\begin{tabular}{|c|c|c|c|c|c|c|c|c|c|c|}
\hline $\begin{array}{l}\text { Flow } \\
\text { Bands } \\
\text { (kcfs) }\end{array}$ & Number of plots & $\begin{array}{l}\text { No. Flow } \\
\text { Fluct. }\end{array}$ & $\begin{array}{l}\text { N_h, } \\
\text { \#plots * } \\
\text { \#fluct }\end{array}$ & W_h & $\begin{array}{c}\mathrm{n} \_\mathrm{h} \\
\text { (num. } \\
\text { samples) }\end{array}$ & $\begin{array}{c}\mathrm{x} \text {.h, } \\
\text { no./plot }\end{array}$ & $\begin{array}{c}\mathbf{N} \_h^{*} \mathbf{x} \_\mathbf{h}, \\
\text { no. }\end{array}$ & $\mathbf{s}_{-} \mathbf{h}^{2}$ & W_h'mean_h & 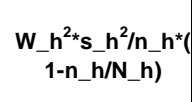 \\
\hline$=80-120$ & "6425 & "8.8 & "56219 & 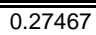 & 131 & 0.9643 & "54212 & 208.7351 & 0.2649 & $\overline{0.01651}$ \\
\hline $120-160$ & 4082 & 13.6 & 55413 & 0.27074 & 321 & 0.9026 & 50016 & 75.7868 & 0.2444 & 0.01721 \\
\hline $160-200$ & 4214 & 16.4 & 69004 & 0.33714 & 241 & 0.2738 & 18893 & 2.3622 & 0.0923 & 0.00111 \\
\hline $200-240$ & 4351 & 5.5 & 24039 & 0.11745 & 73 & 0.1071 & 2575 & 0.5342 & 0.0126 & 0.0001 \\
\hline Sum & 19072 & & 204675 & 1 & 766 & & $\begin{array}{c}\text { total } \\
\text { number } \\
125695\end{array}$ & & $\begin{array}{c}\text { mean_est, } \\
\text { no./plot } \\
0.614\end{array}$ & $\begin{array}{c}\operatorname{var}(\text { mean_est }) \\
0.035\end{array}$ \\
\hline & & & & & & & $\begin{array}{c}\text { std(total_n } \\
\text { o.) } \\
74971\end{array}$ & & & $\begin{array}{c}\text { std(mean_est) } \\
0.187\end{array}$ \\
\hline
\end{tabular}

Pacific Northwest National Laboratory

October 1999 


\section{Appendix D}

Data used in Hanford Reach Fall Chinook Salmon Fry Production Estimate 
1998 Hanford Reach Fall Chinook Salmon Sport Harvest (Watson 1999)

\begin{tabular}{cccccc}
\hline Week & Male & Female & Jack & $\begin{array}{c}\text { Total } \\
\text { Adults }\end{array}$ & $\begin{array}{c}\text { Percent } \\
\text { Female }\end{array}$ \\
\hline October 26-November 1 & 11 & 18 & 3 & 29 & 62.1 \\
October 19-25 & 133 & 84 & 24 & 217 & 38.7 \\
October 12-18 & 232 & 160 & 48 & 392 & 40.8 \\
October 5-11 & 181 & 155 & 85 & 336 & 46.1 \\
September 28-October 4 & 76 & 96 & 37 & 172 & 55.8 \\
September 21-27 & 32 & 56 & 20 & 88 & 63.6 \\
September 14-20 & 6 & 8 & 4 & 14 & 57.1 \\
September 7-13 & 1 & 4 & 1 & 5 & 80.0 \\
August 31-September 6 & 1 & 1 & 0 & 2 & 50.0 \\
\hline Total & 673 & 582 & 222 & 1,255 & 46.4 \\
\hline
\end{tabular}

Published estimates of mortality (\%) of chinook to various development stages in fresh water (mean of ranges in Parentheses)

\begin{tabular}{|c|c|c|c|c|c|c|c|}
\hline $\begin{array}{c}\text { River } \\
\text { system }\end{array}$ & $\begin{array}{c}\text { Eggs } \\
\text { not } \\
\text { spawned }\end{array}$ & $\begin{array}{c}\text { Losses } \\
\text { at } \\
\text { spawning } \\
\end{array}$ & $\begin{array}{c}\text { Spawning } \\
\text { to } \\
\text { eyed stage }\end{array}$ & $\begin{array}{c}\text { Spawning } \\
\text { to } \\
\text { alevin } \\
\end{array}$ & $\begin{array}{l}\text { Spawning } \\
\text { to } \\
\text { emergence }\end{array}$ & $\begin{array}{c}\text { Spawning } \\
\text { to } \\
\text { fry/smolt }\end{array}$ & Remarks \\
\hline \multirow[t]{2}{*}{ Mill Cr. (CA) } & & & & & $85-100(96)$ & & $\begin{array}{l}\text { Planted eggs, } \\
\text { flooding channel }\end{array}$ \\
\hline & & & & & 40 & & $\begin{array}{l}\text { Planted eggs, } \\
\text { controlled flow }\end{array}$ \\
\hline Fall Cr. (CA) & & & & & $68-93(85)$ & & Natural spawning \\
\hline Prairie Cr. (CA) & & 1.0 & $0-25.5(10)$ & $14-25(18)$ & & & $\begin{array}{l}\text { Natural spawning } \\
\text { redd sampling }\end{array}$ \\
\hline Yakima (WA) & 1.0 & & & & & 84-95 (89) & $\begin{array}{l}\text { Stream-type, weir } \\
\text { counts of smolts }\end{array}$ \\
\hline Lemhi (ID) & & & & 27 & 58 & & $\begin{array}{l}\text { Emergence trap } \\
\text { over one redd }\end{array}$ \\
\hline Cowichan (BC) & & & & & & 84-91 (87) & $\begin{array}{l}\text { Ratio of fry/smolt } \\
\text { migrants to eggs }\end{array}$ \\
\hline Nanaimo (BC) & & & & & & $80-88(84)$ & $\begin{array}{l}\text { Ratio of fry/smolt } \\
\text { migrants to eggs }\end{array}$ \\
\hline Big Qualicum (BC) & 12 & & & & & $93-100$ & Before flow control \\
\hline & & & & & & $80-88$ & After flow control \\
\hline \multicolumn{8}{|l|}{ Skeena System } \\
\hline Bear R. (BC) & 25 & & & & & & \\
\hline Morice R. (BC) & 1 & & & & & & \\
\hline Babine R (BC) & 20 & & & & & & \\
\hline Kamchatka (USSR) & 1 & 88 & & $1-6(3)$ & & & Redd Sampling \\
\hline
\end{tabular}




\section{Appendix E}

Effects of Water Level Fluctuations on Benthic Macroinvertebrates in the Hanford Reach, Columbia River 
EFFECTS OF WATER LEVEL FLUCTUATIONS ON BENTHIC

MACROINVERTEBRATES IN THE HANFORD REACH, COLUMBIA RIVER

\author{
A Thesis \\ Presented in Partial Fulfillment of the Requirements for the \\ Degree of Master of Science \\ with a \\ Major in Fishery Resources \\ in the \\ College of Graduate Studies \\ University of Idaho \\ by
}

Eric J. Stark

May 2001

Major Professor: David H. Bennett, Ph.D. 


\section{AUTHORIZATION TO SUBMIT THESIS}

This thesis of Eric J. Stark, submitted for the degree of Master of Science with a major in Fishery Resources and titled "Effects of Water Level Fluctuations on Benthic Macroinvertebrates in the Hanford Reach, Columbia River," has been reviewed in final

form. Permission, as indicated by the signatures and dates given below, is now granted to submit final copies to the College of Graduate Studies for approval.

Major Professor

Date

David H. Bennett

Committee

Members

Date

C. Michael Falter

Date

Christopher J. Williams

Department

Administrator

Date

George W. LaBar

Discipline's

College Dean

Date

Charles R. Hatch

Final Approval and Acceptance by the College of Graduate Studies

Charles R. Hatch

Date 


\begin{abstract}
The Hanford Reach, the last free-flowing section of the Columbia River in the U.S., provides critical habitat for wild fall chinook salmon, Oncorhynchus tshawytscha. Although free flowing, the Hanford Reach is affected by rapid changes in discharge from hydroelectric operations of Priest Rapids Dam, immediately upstream. Fluctuations in discharge result in wide changes in water levels that can strand biota in shallow areas. This study assessed the effects of diel fluctuations in flow on macroinvertebrates, important for their food role for rearing chinook salmon in the reach.

Macroinvertebrate colonization on artificial substrates was examined to determine sufficient sample size, colonization duration, substrate type, and sampling locations for use in assessing the 21-day (long-term) effects of water level fluctuations on the benthic invertebrate community during 1999. Preliminary sampling during late summer of 1998 revealed the fauna was low in diversity and dominated primarily by Chironomidae (midges) and Trichoptera (caddisfly) larvae, collectively comprising $87 \%$ of the fauna by density. Bricks were selected as our substrate for 1999 (year 2) studies and a 4 week colonization duration because of lower variability and concern for sample processing time. The use of artificial substrates provided the most representative results of the faunal dynamics experiencing diel water level fluctuations because they allowed sufficient replication to minimize variability.

During the summer of 1999, long-term effects were quantified by assessing macroinvertebrate density and biomass on exposure treatment groups of brick artificial substrates placed along a test transect experiencing varying exposures to air due to fluctuating water levels. Results from the long-term test transects clearly show that
\end{abstract}


benthic macroinvertebrates of the periodically exposed areas (all treatment exposure substrates) were severely limited in density and biomass compared to the communities on continually inundated areas (control substrates). Total invertebrate density was approximately $4 \mathrm{x}$ higher on bricks never de-watered than on substrates exposed only 1-24 hours. Mean total invertebrate density and biomass were reduced by $59 \%$ and $65 \%$, respectively, from substrates exposed up to 24 hours to substrates never de-watered. Substrates exposed during more than 361 hours of the test period experienced as much as a 99\% reduction in total density and biomass relative to control substrates.

We also found midges and some 'other' taxa were able to tolerate up to 24 hours of exposure to air during the long-term (21 day) test period without declines in density. Mean weight of individual midges was decreased significantly with long durations of exposure to air. Midges also comprised an increasingly greater proportion of the brick substrate community with increasing duration of exposure to air, which suggests that these smaller individuals are the first to recolonize previously de-watered areas and/or they are less mobile and are stranded when water levels recede, yet escape desiccation. The long-term results also revealed that caddis and 'other' groups are affected much more drastically than midges. However, net-building trichopterans such as those in the Hydropsyschidae family were found at all of our sites and at densities of $11 / \mathrm{m}^{2}$ despite extreme fluctuations in discharge.

Short term effects of water level fluctuations were also determined through investigation of invertebrate drift response and artificial exposure tests. Invertebrate drift response, measured as drift density, was assessed under changes in discharge at different depths and time of day. Nearshore invertebrate drift sampling revealed increased midge 
drift density as discharge and water levels increased and decreased midge drift density as discharge and water levels dropped, however this pattern was not significant for the caddis and 'other' groups. All three taxa groups occurred at significantly higher drift densities with increasingly deeper collection depths. In addition, caddis drift density was significantly lower during daytime and higher during nighttime samples; yet, time of day had no significant effect on midge or 'other' drift densities.

Effects of artificial short-term exposures were examined by estimating relative mortality, mobility, and susceptability of macroinvertebrates exposed to air on brick artificial substrates. A dramatic decrease in survival was found with even short exposure durations. Survival of midge and 'other' taxa groups dropped to $50 \%$ with just 1 hour of exposure. Although highly variable, the survival of invertebrates generally continued to decline with longer duration of exposure. We found the smaller and less mobile early instars of midges and mayflies incurred higher mortality. Approximately $40 \%$ of invertebrates exposed were found to migrate vertically to avoid desiccation after only 30 minutes of exposure to air.

The Hanford Reach macroinvertebrate community is dominated by midges and caddisfly larvae, both were found to be quite resilient to water level fluctuations. Although the present community may be relatively tolerant to these changes, the detrimental effect is most likely on the overall community productivity, which may be much more ecologically significant. The effects of diel water level fluctuations on overall benthic macroinvertebrate population abundance or productivity must be quantified to gain an even better understanding because of their importance as a food source for juvenile chinook salmon in the Hanford Reach, Columbia River. 


\section{ACKNOWLEDGMENTS}

Funding of this work was provided by the Bonneville Power Administration through the Washington Department of Fish and Wildlife. I thank Paul Wagner and C.E. Cushing for study planning and logistical support of sampling efforts. I also thank Michael Falter, Merlyn Brusven, Russell Biggam, and Geneva Pym, of the University of Idaho, for providing crucial laboratory assistance and guidance. Additionally, Chris Williams and Kirk Steinhorst, Division of Statistics, of the University of Idaho, provided invaluable assistance and direction in the statistical analysis of the data. Bill Edwards and John Nuggent and many people from Grant County Public Utility District and Washington Department of Fish and Wildlife also contributed to the field sampling effort. I give special thanks to Pete Russell, Bill Edwards, Paul Letizia, Dustin Hinson, Clayton Nalder, Lance Clarke, Tamara Taylor, Shannon Peterson, and numerous others who spent endless hours in the laboratory sorting and identifying benthic macroinvertebrates. 
TABLE OF CONTENTS

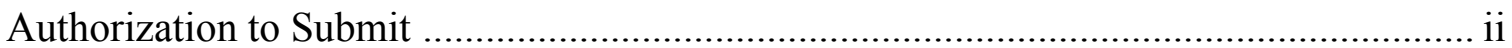

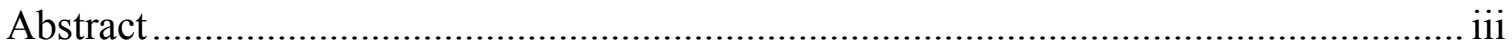

Acknowledgments.............................................................................................. vi

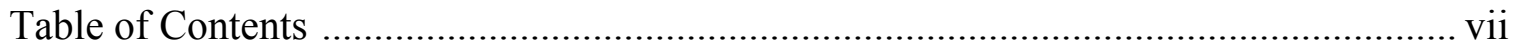

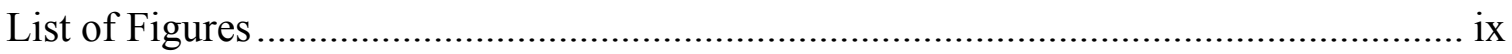

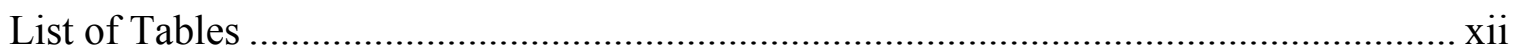

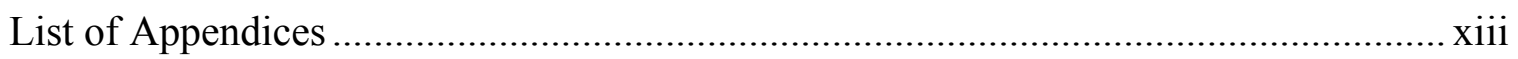

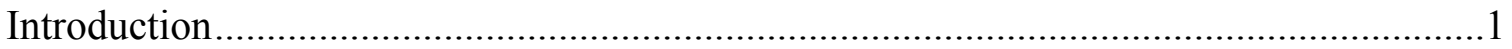

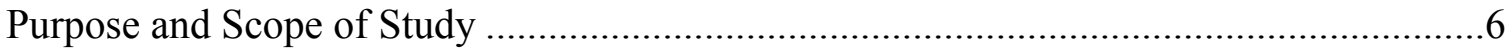

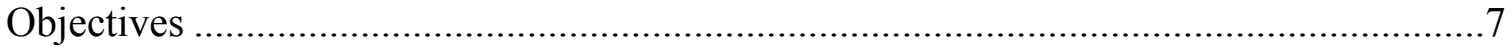

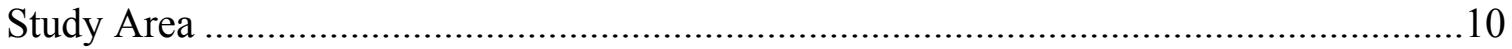

Methods

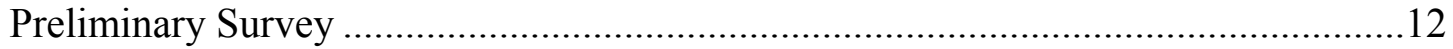

Long-Term Effects of Dewatering............................................................................15

Short-Term Effects of Dewatering

Artificial Exposures ...........................................................................

Results

Preliminary Survey

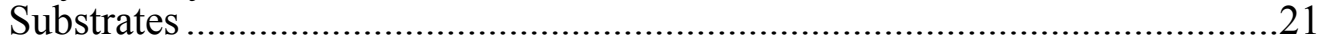

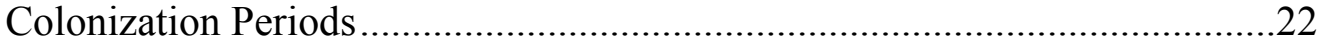

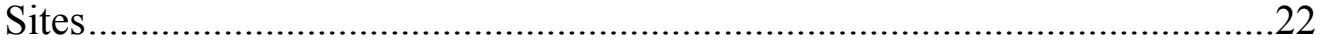

Long-Term Effects of Dewatering

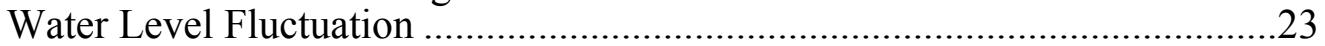

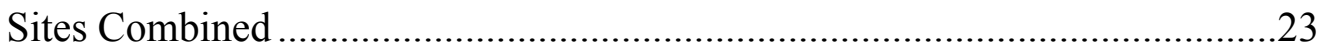

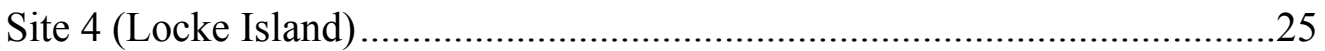

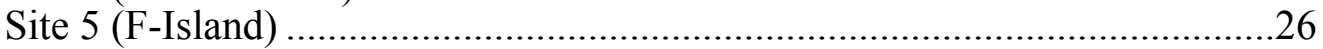

Short-Term Effects of Dewatering

Invertebrate Drift

Nearshore

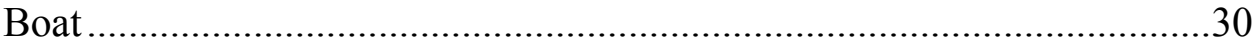

Proportion of Benthos in Drift .................................................................31

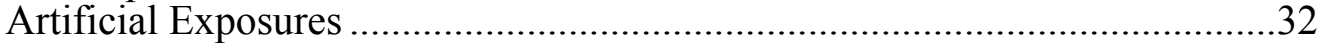


Discussion

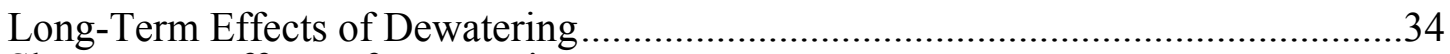

Short-Term Effects of Dewatering

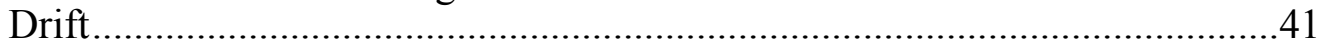

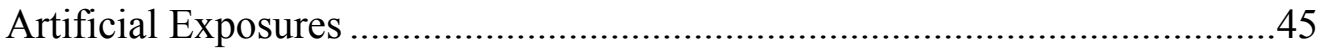

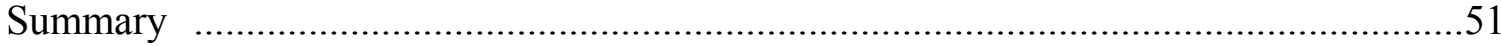

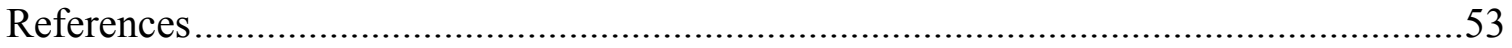

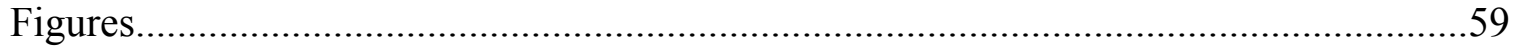

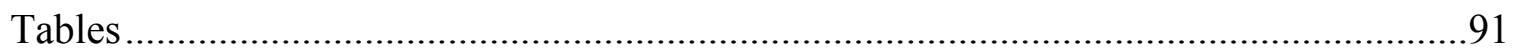

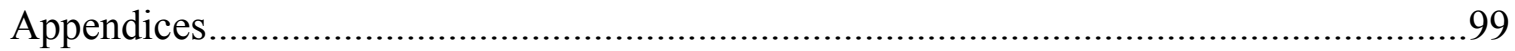




\section{LIST OF FIGURES}

Figure 1. Location of preliminary survey (Objective 1; Sites 1-3) and long-term assessment (Objective 2) invertebrate sampling sites (4 and 5) used within the Hanford Reach, Columbia River, Washington, during August - September, 1998 and September - October, 1999, respectively ......59

Figure 2. Daily mean discharge from Priest Rapids Dam in 1998

Figure 3. Preliminary sampling design to determine optimal substrate, colonization period, sites, and sample size (Objective I) for year-2 tests of water level fluctuation effects.

Figure 4. Artificial substrate sampling design for year-2 assessment of long-term effects of water level fluctuations on benthic macroinvertebrates (Objective 2)

Figure 5. Boat and near-shore invertebrate drift sampling methods conducted to assess short-term effects of water level fluctuations on macroinvertebrates, numbers indicate drift net sampling depths.

Figure 6. Mean proportional density and biomass of benthic macroinvertebrates collected from 12 August to 23 September, 1998 on all preliminary survey artificial substrates in the Hanford Reach, Columbia River, Washington......

Figure 7. Mean density and biomass of midge, caddis, and 'other' taxa categories of macroinvertebrates collected on barbecue basket (BBQ) and brick artificial substrates in the Hanford Reach, Columbia River, Washington, from 12 August to 23 September, 1998. Vertical error bars represent (+/-) one standard error of the total density and biomass

Figure 8. Mean proportional density of benthic macroinvertebrates collected on barbecue basket (BBQ) and brick artificial substrates colonized for 4 or 6 weeks at River Mile (RM) 360.5 (Site 1); RM 370.5 (Site 2); and RM 375.0 (Site 3) in the Hanford Reach, Columbia River, Washington, from 12 August to 23 September, 1998

Figure 9. Mean proportional biomass of benthic macroinvertebrates (Mollusk weights excluded) collected from barbecue basket (BBQ) and brick artificial substrates colonized for 4 or 6 weeks at River Mile (RM) 360.5 (Site 1); RM 370.5 (Site 2); and RM 375.0 (Site 3) in the Hanford Reach, Columbia River, Washington, from 12 August to 23 September, 1998.

Figure 10. Mean density and biomass of midge, caddis, and 'other' taxa categories of macroinvertebrates collected on artificial substrates following 4 week or 6 week colonization periods in the Hanford Reach, Columbia River, Washington, from 12 August to 23 September, 1998. Vertical error bars represent $(+/-)$ one standard error of the total density and biomass 
Figure 11. Mean density and biomass of midge, caddis, and 'other' taxa categories of benthic macroinvertebrates collected on artificial substrates at River Mile (RM) 360.5 (Site 1) RM 370.5 (Site 2) and RM 375.0 (Site 3) of the Hanford Reach, Columbia River, Washington, from 12 August to 23 September, 1998. Vertical error bars represent (+/-) one standard error of the total density and biomass.

Figure 12. Water elevation changes during long-term test of effects of water level fluctuations on macroinvertebrates in the Hanford Reach, Columbia River, Washington, from 16 September through 5 October, 1999.

Figure 13. Changes in benthic macroinvertebrate density and biomass with increasing duration of exposure to air air during a 21-day test period (Objective 3) at Site 4 (Locke Island) in the Hanford Reach, Columbia River, Washington, 16 September through October 5, 1999

Figure 14. Changes in mean individual biomass of benthic macroinvertebrates found on artificial substrates with increasing duration of exposure to air during a 21-day test period (Objective 3) at Site 4 (A) and Site 5 (B) in the Hanford Reach, Columbia River, Washington, 16 September through 5 October, 1999.

Figure 15. Benthic macroinvertebrate density and biomass with increasing duration of exposure to air during a 21-day test period (Objective 3) at Site 5 (F-Island) in the Hanford Reach, Columbia River, Washington, 16 September through 5 October, 1999.

Figure 16. Comparison of macroinvertebrate community composition, by density and biomass, on 'control' artificial substrates between Site 4 (Locke Island) and Site 5 (F-Island) long-term test locations in the Hanford Reach, Columbia River, Washington, 16 September through 5 October, 1999.

Figure 17. Comparison of benthic macroinvertebrate density (A) and community composition (B) from brick artificial substrates and kick-screen sampled natural substrates in the Hanford Reach, Columbia River, Washington, October, 1999.

Figure 18. Changes in discharge $\left(\mathrm{m}^{3} / \mathrm{sec}\right)$ and water elevation (meters above mean sea level) during near-shore invertebrate drift sampling, August 17-18 (A) and August 27-29 (B), 1999 at Site 4 (Locke Island) in the Hanford Reach, Columbia River, Washington....

Figure 19. Changes in macroinvertebrate drift density with changes in discharge, collected in near-shore (A) and boat (B) drift sampling at Site 4 (Locke Island) in the Hanford Reach, Columbia River, Washington, August, 1999...77

Figure 20. Box plots of mean I) midge, II) caddis, and III) 'other' drift density $\left(\# / \mathrm{m}^{3} / \mathrm{sec}\right)$ by depth $(0.45,0.75$, and $1.0 \mathrm{~m}$.) for the combined near-shore drift sampling at Site 4 (Locke Island) in the Hanford Reach, Columbia River, Washington, August 17-18 and 28-29, 1999. Plots not sharing the same small letters indicate significant differences $(\mathrm{p}<0.05)$ between depths 
Figure 21. Box plots of mean I) midge, II) caddis, and III) 'other' drift density ( $\left.\# / \mathrm{m}^{3} / \mathrm{sec}\right)$ by time of day ( $\mathrm{D}=$ day, $\mathrm{E}=$ evening, $\mathrm{N}=$ night, $\mathrm{M}=$ morning) for the combined near-shore drift sampling at Locke Island (Site 4) in the Hanford Reach, Columbia River, Washington, August 17-18 and 28-29, 1999. Plots not sharing the same small letters indicate significant differences $(p<0.05)$ between times of day

Figure 22. Changes in discharge $\left(\mathrm{m}^{3} / \mathrm{sec}\right)$ and water elevation (meters above mean sea level) during boat invertebrate drift sampling, August 28-29, 1999 at Site 4 (Locke land) in the Hanford Reach, Columbia River, Washington

Figure 23. Box plots of mean I) midge, II) caddis, and III) 'other' drift density by depth (1.5 and $2.1 \mathrm{~m}$.) for the boat drift sampling at Site 4 (Locke Island) in the Hanford Reach, Columbia River, Washington, August 28-29, 1999. Plots not sharing the same small letters indicate significant differences $(p<0.05)$ between depths.

Figure 24. Box plots of mean I) midge, II) caddis, and III) 'other' drift density by time of day $(\mathrm{D}=$ day, $\mathrm{E}=$ evening, $\mathrm{N}=$ night, $\mathrm{M}=$ morning) for the boat drift sampling at Site 4 (Locke Island) in the Hanford Reach, Columbia River, Washington, August 17-18 and 27-29, 1999. Plots not sharing the same small letters indicate significant differences $(p<0.05)$ between times of day

Figure 25. Comparison of macroinvertebrate community composition (by density) between boat drift and kick-screen natural substrate samples, collected from the Hanford Reach, Columbia River, Washington, August 28-29, 1999

Figure 26. Survival of major invertebrate taxa groups with increasing duration of exposure to air during short-term exposure tests on brick (A) and tile (B) artificial substrates from laboratory-checked samples. Lines represent linear regression relationships, with equation of line and strength of linear relationship $\left(\mathrm{r}^{2}\right)$ for each taxa group

Figure 27. Measures of relative migration of major invertebrate taxa groups (\% mobile) with increasing duration of exposure to air during short-term exposure tests from both laboratory- (A) and field-checked (B) samples

Figure 28. Survival of major invertebrate taxa groups with increasing duration of exposure to air during short-term exposure tests on brick (A) and tile (B) artificial substrates from field-checked samples without replication. Lines represent linear regression relationships, with equation of line and strength of linear relationship $\left(\mathrm{r}^{2}\right)$ for each taxa group

Figure 29. Comparison of mean proportional abundance and biomass of benthic macroinvertebrates between Surber samples collected in 1952 by Robeck et al. (1954), and from our artificial substrate samples colonized from 12 August to 23 September, 1998 (mollusk wts. excluded) in the Hanford Reach, Columbia River, Washington 
Figure 30. Mean daily discharge from Priest Rapids Dam, Columbia River from 1 August through 30 September, 1998. Dates of deployment and 4 or 6 week retrievals of artificial substrates are as indicated

Figure 31. Benthic macroinvertebrate sample size determination with example calculations using brick artificial substrate samples colonized for 6 weeks at Site 2

Figure 32. Comparison of brick versus water level elevation distributions at Site 4 (Locke Island) and Site 5 (F-Island) test sites 


\section{LIST OF TABLES}

Table 1. Mean benthic macroinvertebrate density (No. $\left./ \mathrm{m}^{2}\right)$, standard error (SE), ranges, sample sizes, and coefficient of variation (CV) on artificial substrata in the Hanford Reach, Columbia River. Site 1 was at river mile 368.0, site 2 at RM 370.5, and site 3 at RM 379.0. Colonization periods (4wk or $6 \mathrm{wk}$ ) and sites $(1,2,3)$ show the combined density of both bricks and baskets

Table 2. Mean benthic macroinvertebrate dry weight biomass $\left(\mathrm{g} / \mathrm{m}^{2}\right)$, standard error (SE), ranges, sample sizes, and coefficient of variation (CV) on artificial substrata in the Hanford Reach, Columbia River. Site 1 was at river mile 368.0, site 2 at RM 370.5, and site 3 at RM 379.0. Colonization periods (4wk or $6 \mathrm{wk})$ and sites $(1,2,3)$ show the combined density of both bricks and baskets

Table 3. Water level changes at Locke Island (Site 4) and F Island (Site 5) during the 21-day long-term test period in the Hanford Reach, Columbia River, Washington. Water elevations are expressed in meters above mean sea level

Table 4. Summary of long-term objective exposure treatment groups, hours of exposure, percent of time exposed, and sample sizes at Locke and F-Island sites, Hanford Reach, Columbia River

Table 5. Checklist of mean density (No. $/ \mathrm{m}^{2}$ ) and percent composition (\%) of macroinvertebrate taxa by density along a long-term exposure test transect. Mean values of total density and biomass, percent reduction and percent (\%) midge by density and biomass, total taxa, total individuals, and taxonomic diversity for both sites combined

Table 6. Checklist of mean density $\left(\mathrm{No} . / \mathrm{m}^{2}\right)$ of macro-invertebrate taxa along a longterm exposure test transect. Mean values of total density and biomass, total percent reduction and percent midge by density and biomass, total taxa, total individuals, and taxonomic diversity for Locke Island (Site 1)....

Table 7. Checklist of mean density $\left(\mathrm{No} . / \mathrm{m}^{2}\right)$ of macroinvertebrate taxa along a longterm exposure test transect. Mean values of total density and biomass, percent reduction and percent midge by density and biomass, total taxa, total individuals, and taxonomic diversity for Site 2 (F-Island) ....

Table 8. Required sample size (n) to estimate benthic macroinvertebrate mean density to within the specified accuracy of the true mean, for each combination of substrate, colonization, and site 


\section{LIST OF APPENDICES}

Appendix 1. Checklist of benthic macroinvertebrate taxa collected on artificial substrates in the Hanford Reach, Columbia River, categorized by

percent occurrence in samples

Appendix 2. Statistical results ( $\mathrm{p}$-values and degrees freedom in parenthesis) from a partially-nested analysis of variance (ANOVA) of invertebrate taxa group mean density and biomass (Bio) with exposure treatment groups for both sites.

Appendix 3. Statistical results (p-values and degrees freedom) from a partially-nested analysis of variance (ANOVA) of the average weight of invertebrate taxa categories with exposure treatment groups for both sites

Appendix 4. Statistical results (degrees freedom and p-values) from a partially-nested analysis of variance (ANOVA) of the effect of exposure duration (treatment) on invertebrate taxa group mean density and biomass (Bio) for site 1 (Locke-Island) only

Appendix 5. Least Squares Means pairwise comparisons of midge, caddis, and 'other' groups mean density and biomass from site 1 (Locke Island) and site 2 (F-Island)

Appendix 6. Statistical results ( $\mathrm{p}$-values and degrees of freedom in parenthesis) from a partially-nested analysis of variance (ANOVA) of the average weight of invertebrate taxa categories with exposure treatment groups, for sites I and II separately

Appendix 7. Statistical results ( $\mathrm{p}$-values and degrees of freedom in parenthesis) from a partially-nested analysis of variance (ANOVA) of invertebrate taxa group mean density and biomass with exposure treatment groups for site 2 (F-Island) only

Appendix 8. Statistical results (p-values and degrees freedom in parenthesis) from a factorial analysis of covariance (ANCOVA) to test for the effect of discharge; and a partially-nested analysis of variance (ANOVA) to test for the effects of depth and time of day (diel) on invertebrate drift density from nearshore drift sampling, August 17-18 and 27-29, 1999 at site 1 (Locke-Island) in the Hanford Reach, Columbia River, Washington

Appendix 9. Statistical results ( $\mathrm{p}$-values and degrees freedom in parenthesis) from a factorial analysis of covariance (ANCOVA) to test for the effect of discharge; and a partially-nested analysis of variance (ANOVA) to test for the effects of depth and time of day (diel) on invertebrate drift density from boat drift sampling, August 27-29, 1999 at site 1 (LockeIsland) in the Hanford Reach, Columbia River, Washington 
Appendix 10. Statistical results (p-values and degrees freedom in parenthesis) from a factorial analysis of variance (ANOVA) of average mortality rates of invertebrate taxa groups found on both brick and tile substrata under different exposure treatment groups ……………………………………......104

Appendix 11. Statistical results (p-values and degrees freedom) from an analysis of variance (ANOVA) of the average mortality rates of invertebrate taxa categories with exposure treatment groups, sites separate. 


\section{INTRODUCTION}

Aquatic invertebrates serve an important role in the structure and function of river ecosystems. Invertebrates represent an intermediate link in the plant-to-fish food chain, and their role is integral in the support of viable fish populations (Brusven et al. 1974). Invertebrates serve as an important food source to both downstream migrating and rearing salmonids. Dauble et al. (1980) reported age-0 chinook salmon (Oncorhynchus tshawytscha) in the Hanford Reach of the Columbia River consumed mainly dipteran (midge) and trichopteran (caddis) insects. In addition, Nietzel (1996) reported a close association between organisms in the stomachs of nearly all juvenile and adult fishes and the benthic and drift invertebrate communities in the Hanford Reach, Columbia River. Therefore, a reduction in macroinvertebrates as a result of drastic habitat changes such as water level fluctuations could greatly influence the productivity of the related fish community.

The Hanford Reach is the last free-flowing section of the Columbia River in the U.S. upstream from the estuary mouth and provides critical habitat for the fall chinook salmon stock in the Columbia River. Currently, the largest of the two remaining wild stocks of fall chinook salmon in the Columbia River spawns in the Hanford Reach. Determining the ecological impacts of fluctuations in water level will help in developing plans to adjust hydropower operations to lessen effects on aquatic species and protect critical habitat.

Although free flowing, the Hanford Reach is affected by drastic changes in discharge from the hydroelectric Priest Rapids Dam at the upstream end of the reach. 
Daily and even hourly water level fluctuations exceeding 1.7 vertical $\mathrm{m}$ (5 ft) occur along the reach (Nietzel 1996) as a result of hydropeaking operations that strand rearing chinook salmon and their food items (Bauersfeld 1978; Becker et al. 1981). As a result, concern has been expressed about the impacts of these water level fluctuations on macroinvertebrate food production and populations.

Biotic communities of river ecosystems are commonly hypothesized to respond and adjust in predictable and observable ways to a gradient of physical conditions along the length of a river. This theory, proposed by Vannote et al. (1980), called the River Continuum Concept (RCC), suggests that river ecosystems and their channels are in dynamic equilibrium. Based on the state of these physical variables, structural and functional characteristics of stream communities will therefore change accordingly. Thus, any given river system will likely follow a gradient of conditions from headwaters to mouth. Rivers will change from local energy inputs of coarse organic matter and heterotrophic processes in headwaters to transport and autotrophic production in mid reaches to progressively smaller organic material and return to heterotrophy in downstream waters. The composition of stream invertebrate functional feeding groups along this continuum will reflect the changes in particle size (food resources) from a dominance of shredders in headwaters to mostly collectors in large rivers (Vannote et al. 1980).

The RCC was developed specifically for natural, unperturbed river ecosystems, but the concept also can be applied to instances of un-natural or man-made disturbances (Ward and Stanford 1983). Human alterations, such as damming and impoundment of rivers can function as reset mechanisms, which may cause a shift in variables along the 
continuum. Rivers downstream of dams, therefore, may change in ways more consistent with the ecology of smaller or larger order streams depending on the operational characteristics of the dam and its location in the river system. For example, a water storage dam on a second order coldwater stream may alter the downstream section by prematurely changing community metabolism from heterotrophy to autotrophy and dominance of particulate organic matter (POM) to fine particulate organic matter (FPOM). Thus, the invertebrate fauna will become a community dominated by the collector and grazer functional feeding groups.

The damming of major rivers for hydroelectric power generation throughout the world has revealed several obvious patterns of effects on their downstream riverine ecosystems. No use of water, with the possible exception of gross waste disposal, can have as massive an effect on the original ecology of a river as large-scale hydroelectric development (Ruggles and Watt 1975). The physical variables of thermal and flow regimes are most often observed to change downstream of hydroelectric dams, ultimately affecting the river biota. My primary interest involved the implications of changes in flow regime in the Hanford Reach of the Columbia River.

Changes in flow regime downstream of dams can be described in terms of four general categories. The receiving stream may be affected by seasonal flow constancy, reduced flow, increased flow, and short-term flow fluctuation (Ward 1976). These scenarios occur or often are associated with each other depending on the operational characteristics of the dam. Seasonal flow constancy usually results from the storage of water during spring run-off and the release of reservoir water during historic low flow periods. Reduced or increased flows often occur seasonally relative to pre-dam natural 
flow regimes and are usually caused by release or storage of water to meet downstream needs or demands. Short-term flow fluctuations most often result from power peaking operations at upstream hydroelectric dams. Each of these types of changes in flow regimes are likely to affect the downstream aquatic biota in different ways. Our concern lies with the long term effects ( $>24$ hours) of diel flow fluctuations on macroinvertebrates, which I will describe in better detail in the methods section.

Prior investigations have specified and quantified flow fluctuations by different means yet each has documented the same general pattern of detrimental effects of rapidly varying flows on benthic macroinvertebrates. Flow fluctuation has been described by different researchers on the basis of changes in flow, riffle area, velocity, depth, or wetted substrate. Invertebrate communities have demonstrated reduced species diversity, density, biomass, and mean individual weight as a result of these changing flows (Cushman 1985).

Little information has been collected on the benthic macroinvertebrate fauna in the Columbia River, especially the Hanford Reach. Robeck et al. (1954) studied the Hanford Reach of the Columbia River from spring 1951 to spring 1953. Although the study was largely descriptive, their findings suggested that the Columbia River had "clean water" forms of macroinvertebrates such as mayflies, midges, caddisflies, and mollusks. Areas at depths of 3-5 m contained about 50\% less organisms than shallow riffles. Page and Neitzel (1977a) indicated that their benthic grab samples were codominated by midges and caddisfly larvae. Only on one occasion did any organisms other than midges and caddisfly larvae dominate their grab and artificial substrate samples. Page and Neitzel (1977b) reported that populations of insect larvae were higher 
in the areas sampled in the Columbia River in October and December than in June and July.

Page and Neitzel (1978) used artificial substrates and found similar results to the earlier studies in the Columbia River; the fauna was low in diversity and dominated primarily by midges and caddisfly larvae. Page and Neitzel (1979) reported sampling 14 taxa near Washington Public Power Supply System's Nuclear Projects (WNP) 1, 2 and 4, of the Hanford Reach in which caddisfly larvae dominated during September and December and midges dominated March - June 1977. Caddisfly and midge larvae accounted for more than $90 \%$ of the macroinvertebrate fauna. Page et al. (1979) found similar results between January and August 1978. In addition, no station differences in the abundance of aquatic macroinvertebrates were observed.

This body of literature suggests that three categories of benthic macroinvertebrates - midges, caddisfly larvae, and 'other' (flatworms, mayflies, and other benthic invertebrates) would be the appropriate organisms for assessing effects of water level fluctuations in the Hanford Reach of the Columbia River. 


\section{PURPOSE AND SCOPE OF STUDY:}

The purpose of this study is to evaluate effects of diel water level fluctuations on the benthic macroinvertebrate community downstream of Priest Rapids Dam in the Hanford Reach of the Columbia River (Figure 1). Diel water level fluctuations downstream of electrical power generation facilities can adversely affect shallow water organisms by exposing the shoreline to desiccation. Macroinvertebrates can be affected directly by loss of habitat and desiccation and indirectly by loss of periphyton that is used for food. Numerous authors have reported that the littoral zones of aquatic ecosystems are highly productive for macroinvertebrates and important foraging areas for fishes. However, fluctuating water levels can expose these areas to desiccation and create conditions only inhabitable by more drought tolerant communities. Such water level fluctuations occur downstream of Priest Rapids Dam in the Hanford Reach, Columbia River. Because of the importance of this area to rearing chinook salmon, this study was proposed with the following objectives: 


\section{OBJECTIVES}

Objective 1. (Year-1/1998)-To determine the best location and the best of two different artificial substrates to produce adequate numbers of benthic macroinvertebrates on artificial substrates for Year-2 manipulative studies in the Hanford Reach of the Columbia River.

I examined the colonization of benthic macroinvertebrates on two different artificial substrates at three locations in the Hanford Reach from August 12 through September 23, 1998. To effectively evaluate effects of diel water level fluctuations, sufficient numbers of benthic macroinvertebrates were needed to accurately represent the invertebrate community experiencing these changes. Thus, satisfactory completion of Objective 1 provides data on the best location and substrate for colonization by midges, caddisfly larvae, and 'other' (flatworms, mayflies, and other benthic invertebrates) to be able to test the effects of water level fluctuations on these invertebrates during Year-2 sampling.

Objective 2. (Year-2/1999)-To evaluate the long-term effects of diel fluctuations of water levels on the benthic macroinvertebrate community in the Hanford Reach of the Columbia River.

Information obtained from Objective 1 was used to identify appropriate locations and the best artificial substrate for colonization. Artificial substrates colonized by macroinvertebrates were placed in selected locations for approximately 21 days. Thus, this objective will be referred to as the 'long-term' (21 day) evaluation of effects of diel water level fluctuations on macroinvertebrates. This objective provided data on macroinvertebrate densities and biomass on artificial substrates with varying durations of 
exposure to air as a result of water level fluctuations during the test period, September and October, 1999.

Objective 3. (Year-2/1999) - Evaluate the short-term effects of diel water level fluctuations on the benthic macroinvertebrate community in the Hanford Reach, Columbia River.

Short-term effects of diel water level fluctuations on macroinvertebrates were measured within the temporal confines of 24 hour periods by means of artificial exposures and invertebrate drift sampling. Short-term effects were assessed in regards to three primary implications: exposure or dewatering effects, relative mortality, and recolonization of the macroinvertebrate community experiencing diel water level fluctuations. This objective provided data helping to determine the potential short-term effects of exposures typical in diel hydropeaking cycles of the Hanford Reach in terms of activity and subsequent tolerance, mobility, escapement, and recolonization potential of macroinvertebrates in the zone of daily fluctuation. Investigating this activity of invertebrates may indicate the degree to which the present community may be able to tolerate or compensate for alternating watering and dewatering due to diel fluctuations. 


\section{NULL HYPOTHESES:}

\section{Preliminary Survey}

1. Colonization of artificial substrates is similar between construction bricks and barbecue baskets and macroinvertebrate colonization is not different between 4 or 6 week colonization periods.

\section{$\underline{\text { Long-Term Effects of Water Level Fluctuations }}$}

2. Macroinvertebrate density and biomass on artificial substrates are similar among different durations of long-term exposure to air.

\section{$\underline{\text { Short-Term Effects of Water Level Fluctuations }}$}

3. Macroinvertebrate drift density is not affected by changes in discharge or fluctuating water levels nor dissimilar among time periods and sampling depths.

4. Relative mortality of macroinvertebrates on artificial substrates exposed to air is not different among short-term exposure periods or among invertebrate taxa within an exposure period. 


\section{STUDY AREA}

The Hanford Reach of the Columbia River is a $81.6 \mathrm{~km}$ (51 mile) free-flowing section extending from RM (river mile) 396 to RM 345 (Figure 1). The Priest Rapids Dam, at the upstream end of the reach (RM 396), has been in full operation since September 1961 and has influenced the daily flow regimen of the Hanford Reach. Daily average discharges range from 700 to $1008 \mathrm{~m}^{3} / \mathrm{s}$. Monthly mean discharge typically peaks between April and June, during spring runoff from snowmelt, and is lowest from September through October (Nietzel 1996; Figure 2). Sampling locations are as follows:

\section{PRELIMINARY SURVEY}

Three sampling locations were selected. The first location was at approximately RM 368 while the second and third sites were at RM 370.5 and 379, respectively (Figure 1). The third location (RM 379) is considered the reference site since artificial substrates have been successfully colonized by target organisms at this location (C. Cushing, Retired, Battelle Northwest Laboratory, Personal Communication). The three sampling sites also were chosen because of physical similarity.

\section{LONG-TERM EFFECTS OF DEWATERING}

The locations for assessing the long-term effects of diel water level fluctuations on benthic macroinvertebrates were at RM 370.5 (Site 4) and RM 368 (Site 5; Figure 1). These sites were preferred because they are important rearing areas for fall chinook salmon (Paul Wagner, Golder \& Associates, Richland, WA, Personal Communication), 
and are representative of habitats in the Hanford Reach with high potential to be exposed by water level fluctuations. Sites were also chosen considering the degree of shoreline slope. Shallower slopes allowed for ease in deployment, stability of artificial substrates, and to facilitate immediate on-site sample processing.

\section{SHORT-TERM EFFECTS OF DEWATERING}

The short-term effects of diel water level fluctuations on benthic macroinvertebrates were assessed only at Site 4 (RM 370.5; Figure 1). This site was selected because it provided a run-type stream channel with moderate velocities and a shallow sloping shoreline for ease in sampling and on-site processing. 


\section{METHODS and MATERIALS}

\section{PRELIMINARY SURVEY}

The purpose of Year-1 sampling was to identify the best duration, location, and artificial substrate for colonization of benthic macroinvertebrates. Benthic organisms were sampled with artificial substrates primarily because of the difficulty in sampling natural substrates by other means under the extreme conditions of fast current, large, hard substrate, and variable water levels in the Hanford Reach. In addition, artificial substrates can help to standardize the sampling by avoiding confounding differences in substrate size and variability (Rosenberg and Resh 1982). Artificial substrates do not necessarily reflect the entire community dynamics present because they are selective for certain organisms but they do provide a useful means of comparing population trends among locations (Brusven and Trihey 1978).

Benthic macroinvertebrates were sampled by deploying two types of artificial substrates (Figure 3). The first type of substrate, described by Benfield et al. (1974), consists of 10 concrete cones, each with a surface area of $171.8 \mathrm{~cm}^{2}$, placed in a wire barbecue basket (Char-broil, Columbus, GA) measuring $25.4 \mathrm{~cm}$ long X $16.5 \mathrm{~cm}$ (10 in. x 6.5 in) in diameter. The cones were soaked for 3 days in $1 \%$ phosphoric acid to remove leachates and an additional 3 days in tap water to eliminate the acid. The second type of substrates were construction bricks with a surface area of $763.1 \mathrm{~cm}^{2}$. Five barbeque baskets and five bricks were attached to a strand of polypropylene rope, and six replicate strands were deployed at each of the three sites, for a total of 180 samples. Each strand with its attached substrates were placed at depths to avoid exposure to air and anchored at 
both ends. Barbecue baskets and bricks were positioned at each location for 4 or 6 weeks, following predicted colonization durations established on the Snake River, Idaho (Haber and Brusven 1982; Nightengale 1999).

Sampling was conducted during late summer or early fall (August - October) for all objectives of this study. Nornally high seasonal flows (in excess of $200 \mathrm{Kcfs}$ ) in March, April, and May with spring runoff, and high flows into June and July from mountain headwater snowmelt, prevent effective sampling during this time of year. Artificial substrates could not be sufficiently secured under the high velocities present during spring and early summer. Sampling during late summer or early fall may also more accurately represent the community since most macroinvertebrates are at peak abundance during this time of year (Johnson et al. 1993). In addition, less variation occurs in life-history features such as emergence, feeding and growth, and movements and migrations of aquatic insects during this time of the year (Resh and Rosenberg 1989).

After each colonization period, the bricks and the baskets were retrieved. Substrates were carefully retrieved to avoid contact with the river bottom or side of the boat to minimize dislodging organisms. Substrates were placed in individual plastic buckets with water, disconnected from each strand, and brushed and rinsed of all attached organisms into their respective labeled sample bucket. Contents of the buckets were then poured through a $0.595 \mathrm{~mm}$ sieve bucket (\#30), rinsed into sample containers, and preserved in 10\% formalin solution with rose bengal dye (Mason and Yevich 1967). All samples were then transported to the laboratory for sorting, identification, enumeration, and weighing. 
Organisms on each substrate were sorted from detritus into the three major taxonomic groups of interest (midge larvae, caddisfly larvae, and all 'other' invertebrates), then enumerated, and weighed collectively by taxonomic group. This produced data on the number and dry weight of each taxonomic group of interest per basket or brick. Dry weights were measured after oven drying at $60^{\circ} \mathrm{C}$ for 36 hours and weighed at two time intervals to assure complete dryness. Sample enumerations and weights were expanded for barbecue basket (x 5.82) and brick samples (x 13.10) for density and biomass estimates per square meter. In addition, taxa were rated "abundant" if found in $60 \%$ or more of all samples collected; "common" if found in $30-60 \%$ of samples; "uncommon" if found in $10-30 \%$ of samples; "rare" if in less than $10 \%$ of samples, and "absent" if not found in samples from a given site or substrate type (Nightengale 1999).

Statistical comparisons of mean density and biomass estimates were made for each substrate, colonization period, and site for the three broad taxonomic groups using a Kruskal-Wallis rank sum test. Based on the variability in colonization of barbecue baskets and bricks, the number of samples necessary to obtain significant statistical power for year-2 studies was calculated for each combination of site, colonization, and substrate. Sample size determination was calculated by classical parametric means using the following statistical equation (Eckblad 1991).

sample size $=(t \text {-value })^{2} x($ sample variance $) /($ accuracy $=0.25) x(\text { sample mean })^{2}$ 


\section{LONG-TERM EFFECTS OF DEWATERING}

The sampling design to assess the long-term effects of diel water level fluctuations on macroinvertebrates (Objective 2) was based on findings from the Year-1 survey. Brick substrates were deployed for a 4 week colonization period at the two selected test sites (Year-1 results). The number of replicates needed to show significant statistical differences was determined to be 10 to 15 bricks per treatment based on a designated accuracy level of $+/-25 \%$.

The historic frequency and amplitude of water level fluctuations was also examined to help locate and optimize our sampling effort. The amount and frequency of water level change during the test period (August - October) for the past 10 years were examined to determine both the horizontal distance and vertical change in height (slope) by which the test transects needed to be placed. Delineation of the fluctuation zone was also crucial in determining the appropriate spacing between substrates, thereby optimizing the sample sizes at mid-elevations where the water levels would most often occur. Twenty strands each with 10 attached bricks were deployed at each of the two sites (Figure 4). These artificial substrates were subjected to diel water level fluctuations for 3 weeks (21 days) at their respective test sites. The brick substrates were then redeployed along a test transect from the potentially highest to lowest water level (i.e., continuous exposure to continuous inundation).

The success of this objective was incumbent on quantifying the water level fluctuations that occurred at the test sites. To accomplish this, we placed pressure sensors about $1 \mathrm{~m}$ below the lowest possible water level to detect the frequency and duration of water level fluctuations (elevation) at the sampling locations. In addition, elevations 
were determined for every brick with a laser level surveying equipment, which together gave us a water level history for each brick. Also, an unsteady flow model, developed by Battelle Pacific Northwest Laboratory, Richland, Washington, predicted water levels for both sites to within (+/-) $0.33 \mathrm{~m}$ based on available USGS digital elevation model (DEM) cross section elevations and Priest Rapids Dam discharge (Richmond and Perkins 1998).

Water level fluctuations were also assessed to compare representativeness of discharge during the test period relative to the past several years. Following 3 weeks exposure to "normal" water level fluctuations, the bricks were retrieved, organisms removed from the substrates (same as Year-1), and preserved. In the laboratory, samples were separated into midge, caddis, and 'other' categories, enumerated, and weighed to dry weight as in Year-1 to determine the inverterbrate community structure.

All bricks subjected to water level fluctuations during the test were categorized into treatment categories based on their elevations, and ultimately by total hours of exposure to air during the entire 21-day test period. This effectively grouped bricks experiencing similar relative conditions of discharge and depth. A minimum of 12 replicate bricks comprised each treatment group for each site. Test bricks below the low water level were 'controls' for comparison with treatment groups that were exposed for various durations.

All invertebrate counts were normalized by logarithmic transformation before conducting parametric statistical tests. A partially-nested ANOVA was performed on the data from each of the three taxonomic groups. The factors used in the model were site, strand nested within site, and treatment. The model tested the effect of duration of exposure to air (treatment categories) on the mean density $\left(\mathrm{No} . / \mathrm{m}^{2}\right)$ and biomass $\left(\mathrm{g} / \mathrm{m}^{2}\right)$ 
of invertebrates $(\alpha=0.05)$ at both sites, using the Statistical Analysis System (SAS 1996). The model also included tests for the effects of site and strand, with treatments crossed with sites but strands nested within sites (strand[site]), hence the partially nested design. I also obtained the average weight of an individual from each of the three taxa groups (midge, caddis, and 'other') by dividing the total biomass by the total number. A partially-nested ANOVA also was performed on this average weight data. Comparisons of average individual biomass $\left(\mathrm{g} / \mathrm{m}^{2}\right)$ values between exposure treatment categories at both sites were then tested $(\alpha=0.05)$ using the Statistical Analysis System (SAS 1996).

A series of least squares means tests also were conducted to determine if differences in density and biomass betweeen sampling sites and among treatments were significant $(\alpha=0.05)$. I pooled the strand within site (strand [site]) error term with the strand by treatment within site (strand * $\operatorname{trt}[$ site]) error term, which provided a slightly conservative test of pair-wise comparisons (Dr. Kirk Steinhorst, University of Idaho, Division of Statistics, Moscow, ID, Personal Communication).

\section{SHORT-TERM EFFECTS OF DEWATERING}

\section{Drift}

Potential drift and subsequent recolonization of invertebrates in areas experiencing water level fluctuations were assessed within diel hydropeaking cycles (Figure 5). Drift sampling was conducted using paired $30 \mathrm{~cm}^{2}$ drift nets with $250 \mu \mathrm{m}$ mesh openings placed on or near the bottom (White et al. 1985). Samples were taken for 30 minutes in duration and collected at 3 hour intervals. Water velocity $(\mathrm{m} / \mathrm{sec})$ was measured in the net opening at 0.6 the net height using a Swoffer (M2000) velocity 
meter. Measurements were taken at the beginning, middle, and end of the sampling period to obtain an estimate of average velocity.

Two different drift sampling methods were conducted to attempt to sample as much of the drift as possible. We sampled the nearshore area using staked nets at 0.45 , 0.75, and $1.0 \mathrm{~m}$ depths and deeper boat sampling from an anchored boat at depths of 1.5 and $2.1 \mathrm{~m}$. Net locations were chosen at depths which ensured the nets were inundated regardless of the discharge. Boat-based invertebrate drift sampling was conducted once for 36 hours on August 28 - 29, 1999. Nearshore sampling was conducted on two occasions; once on August 17 - 18, 1999 then concurrent with boat sampling on August 28 - 29, 1999. Discharge passing through drift nets was then calculated for each sample period by multiplying the water velocity $(\mathrm{m} / \mathrm{sec})$ by the area of the net opening $\left(\mathrm{m}^{2}\right)$. Water levels were also recorded during each test period with the same pressure sensors used in the previous objective and reference discharge data (cfs) from Priest Rapids Dam was obtained from Grant County Public Utility District (PUD). Invertebrate drift was expressed as the numbers of invertebrates per cubic meter of water. The two nearshore drift sampling periods were combined into a single data set. Tests of normality and heteroscedacticity were conducted, and a log transformation was used to normalize the data prior to analysis.

A factorial ANCOVA was used to test for the effect of discharge (covariate) on the mean drift density of the three taxonomic groups for each of the sampling methods separately. Differences in mean drift density were tested $(\alpha=0.05$ level of significance) using the Statistical Analysis System (SAS 1996). Sampling hours were categorized into four periods: day $(\mathrm{D}=0730-1930)$, evening $(\mathrm{E}=1930-2230)$, night $(\mathrm{N}=2230-$ 
0430), and morning $(M=0430-0730)$. Samples were then blocked by time of day and nested within sampling depths. Partially-nested ANOVAs were then conducted to test for the effect of both time of day and depth of sampling on invertebrate drift density. Tukey-Kramer multiple comparison tests also were conducted to determine if differences in drift density between depths and time of day were significant $(\alpha=0.05)$ for each taxa group.

\section{Artificial Exposures}

I used a similar sampling design as in the long-term objective, to assess short-term ( $<12$ hours) invertebrate exposures to air (Objective 3). A total of 10 (eight bricks each) were deployed parallel to shore below low water level and allowed to colonize invertebrates for 4 weeks. Each strand was then retrieved and attached bricks were immediately placed in individual containers on top of small pieces of tile. These tiles were used to assess relative invertebrate movement or vertical migrations to avoid desiccation, which served as our surrogate measure of mobility. Test bricks were exposed for their own designated treatment duration, chosen based on normally occurring exposures typical within the hydropeaking cycles. A minimum of six replicate bricks were sampled per exposure period to maintain statistical power. Each exposure test was terminated by adding water to each container and bricks were then processed by the same methods used for Objective 2 bricks. Bricks and tiles were processed separately for each sample for all exposure durations.

A single 'sub-sample' brick substrate was randomly selected from each exposure period and immediately processed in the field using dissecting scopes. Due to the 
extreme small size of most invertebrates on these substrates, normal visual observations were not practical (Brusven et al. 1974). Invertebrates from these 'sub-samples' were sorted into live and dead categories, and then preserved and processed by the same methods as used for the Objective 2 samples. This gave us estimates of the relative mortality from each exposure duration for the field processed samples, but since I had no true replicates for these samples I could not statistically analyze them.

Mortality rates for the remaining samples, which were not field checked, were obtained from 'best-guess' estimates of live and dead proportions in the laboratory, postpreservation. I performed tests of normality and heteroscedacticity, then log transformed the invertebrate mortality data from these laboratory samples before applying parametric statistical tests. A factorial ANOVA was performed on the data from each of the three taxonomic groups to test for differences in invertebrate mortality as a function of the duration of exposure to air. Substrate surface (brick or tile) and exposure duration (treatment) were the factors included in the model. Differences in mean mortality rate were tested $(\alpha=0.05)$ between and among treatments and substrates using the Statistical Analysis System (SAS 1996). Least squares means tests also were conducted to determine if differences in density and biomass between substrates and treatments were significant $(\alpha=0.05)$. 


\section{RESULTS}

\section{PRELIMINARY SURVEY}

Macroinvertebrates were collected from 148 artificial substrates; 32 substrates could not be used. Mean benthic macroinvertebrate density for all locations was $27,600 / \mathrm{m}^{2}$, and ranged from $500 / \mathrm{m}^{2}$ to $135,000 / \mathrm{m}^{2}$ (Table 1). Mean macroinvertebrate dry weight biomass was $2.26 \mathrm{~g} / \mathrm{m}^{2}$, and ranged from $0.03 \mathrm{~g} / \mathrm{m}^{2}$ to $11.80 \mathrm{~g} / \mathrm{m}^{2}$ (Table 2). Total macroinvertebrate fauna was low in diversity and dominated primarily by Chironomidae (midges) and Trichoptera (caddisfly) larvae (Figure 6). Most of the macroinvertebrate taxa occurred in more than $30 \%$ of the samples collected (Appendix 1), although few taxa besides midge and caddis comprised a large portion of any individual sample.

\section{Substrates}

Mean density was significantly higher on barbecue basket substrates than brick substrates for midge $(\mathrm{p}<0.043)$ and caddis $(\mathrm{p}<0.004)$, but not for 'other' taxa ( $p>0.628$; Figure 7). Mean biomass was significantly higher on barbecue basket substrates for midge $(\mathrm{p}<0.042)$ and caddis $(\mathrm{p}<0.038)$, and no significant difference existed between substrates for the 'other' taxa $(\mathrm{p}>0.450)$.

Comparisons of proportional density of benthic macroinvertebrate taxa between substrates revealed few differences (Figure 8). Barbecue basket samples were colonized by higher percentages of midges and caddis but smaller proportions of the 'other' group than brick substrates. Taxa composition by biomass was similar to composition by 
abundance, with only slightly higher proportions of midges and caddis found on barbecue basket substrates than on brick substrates (Figure 9).

\section{Colonization Period}

The average midge density estimate $\left(18,900 / \mathrm{m}^{2}\right)$ was significantly higher for 4week colonization samples than 6 week $\left(9,170 / \mathrm{m}^{2}\right)$ colonizations $(\mathrm{p}<0.0004$; Figure 10$)$. However, caddis taxa density was significantly lower $\left(8,500 / \mathrm{m}^{2}\right)$ on 4 -week colonization $(p<0.005)$ substrates than 6 week $\left(11,400 / \mathrm{m}^{2}\right)$. No significant difference was found in average density for the 'other' taxa group between colonization periods $(\mathrm{p}>0.109)$. Mean biomass was not significantly different for any of the taxa groups, midge $(p>0.180)$, caddis $(p>0.149)$, and 'other' $(p>0.362$; Figure 10) for 4 or 6 week colonizations.

Comparisons of benthic macroinvertebrate taxa composition (by density) between colonization durations reveal several substantial differences (Figure 8). Six week colonization samples had higher proportions of caddis and smaller proportions of midge than 4 week colonizations. Taxa composition based on biomass revealed little difference among groups between colonization periods (Figure 9).

\section{Sites}

Mean density was significantly different among all three sites for midge $(\mathrm{p}<0.0001)$, caddis $(\mathrm{p}<0.0001)$, and 'other' $(\mathrm{p}<0.0001)$ taxa groups (Figure 11). Substrates at Site 2 (RM 370) were colonized with the highest densities of all three sites 
$\left(*=41,900 / \mathrm{m}^{2}\right.$ ). Mean biomass also was significantly different among sites for midge $(\mathrm{p}<0.014)$, caddis $(\mathrm{p}<0.0001)$, and 'other' $(\mathrm{p}<0.005)$ taxa groups (Figure 11$)$.

Proportional abundance of benthic macroinvertebrate taxa by density and biomas was also significantly different (Figures 8 and 9). Substrates at Site 1 (RM 368) had a much higher proportion of midge and smaller proportion of caddis, and slightly smaller proportion of the 'other' category. Substrate taxa composition by biomass at Site 2 (RM 370) was noticeably different from both Site 1 (RM 368) and Site 3 (RM 379), with a higher proportion of caddis and lower proportions of midge and 'other' taxa categories (Figure 9).

\section{LONG-TERM EFFECTS OF DEWATERING}

\section{Water Level Fluctuation}

Water elevations for both sites, determined from the unsteady flow model, fluctuated from 109.17 to $111.60 \mathrm{~m}$, as much as 2.43 vertical $\mathrm{m}(7.5 \mathrm{ft})$ and as fast as 0.47 $\mathrm{m} / \mathrm{hr}(\mathrm{ft} / \mathrm{hr}$ ) during the entire test period (Figure 12). Water level elevations changed at an average rate of $0.11 \mathrm{~m} / \mathrm{hr}+/-0.0040 \mathrm{~m}(0.37 \mathrm{ft} / \mathrm{hr}+/-0.01 \mathrm{ft})$ at Site 4 , and $0.10 \mathrm{~m} / \mathrm{hr}$ +/- $0.0036 \mathrm{~m}(0.33 \mathrm{ft} / \mathrm{hr}+/-0.01 \mathrm{ft})$ at F-Island (Site 5; Table 3) over the 21-day test.

\section{Sites Combined}

A total of 313 brick artificial substrates were collected from Sites 4 and 5. Eighty-seven substrates were not used because of considerable movement and in some cases subsequent loss of strands or substrates. Eighty-three brick samples were never 
dewatered and therefore considered control substrates for comparison with subsequent exposure treatments (Table 4).

Mean and total invertebrate density and biomass of all three taxa groups were significantly different $(\mathrm{P}<0.0001)$ among exposure treatments for both sites (Appendix 2). Although I found significant interactions between site and treatments for all taxa groups, both sites followed similar trends of drastic decrease in invertebrate density, biomass, and number of individuals. Decreases in the number of taxa and taxonomic diversity also were found with increasing frequency and duration of exposure to air (Table 5).

Averaging Sites 4 and 5 , I found a 59\% reduction in mean total invertebrate density and $65 \%$ reduction in mean total biomass between the first treatment group substrates (1-24h exposure) and the control substrates (never de-watered). Substrates exposed more than 361 hours of the test period (treatment F) experienced a 99\% reduction in total density and total biomass relative to the control substrates (Table 5). Also, the mean weight of individuals was significantly different $(\mathrm{P}<0.0001)$ between exposure treatment groups for the midge taxa group, but not significantly different for caddis $(\mathrm{P}<0.18)$ and 'other' $(\mathrm{P}<0.12)$ groups. However, these differences are confounded by interactions between sites and treatments especially for the midges (Appendix 3).

The artificial substrate community composition also changed drastically with longer frequency and duration of de-watering. The midge taxa group comprised an increasingly higher proportion of the brick substrate community by density and biomass 
with increasing duration of exposure for the first several treatments. However, these changes were not quite as evident for the treatment groups exposed for longer duration ( $>168 \mathrm{~h}$; Table 5). The low densities of organisms (average of $77 / \mathrm{m}^{2}$ ) found on these substrates likely under-represented any accurate estimation of the true community composition.

\section{Locke Island}

We collected a total of 168 brick artificial substrates at Locke Island (Site 4); 32 substrates were not used because of considerable movement and in some cases subsequent loss of strands or substrates. Thirty seven brick samples were never dewatered and therefore considered control substrates for comparison with subsequent exposure treatments (Table 2).

Mean invertebrate density and biomass of all three taxa groups were significantly different $(\mathrm{p}<0.0001)$ among exposure treatment groups (Appendix 4). All taxa groups followed similar trends of drastic decrease in density and biomass (Figure 14). The number of individuals, as well as number of taxa and taxonomic diversity also declined with increasing frequency and duration of exposure to air (de-watering), on brick substrates (Table 6).

Least Squares Means pair-wise comparisons showed significant differences $(p<0.05)$ in density and biomass between the control substrates and the first exposure treatment for all taxa at Locke Island (Appendix 5). Overall, we found was a 79\% reduction in mean total invertebrate density and $73 \%$ reduction in mean total biomass between the first treatment group substrates (1-24 h exposure) and the control substrates. 
Substrates exposed during more than $361 \mathrm{~h}$ of the test period (treatment F) experienced a $99 \%$ reduction in total invertebrate density and biomass relative to the control substrates (Table 6). After the initial drop in density and biomass from control to the first treatment, biomass of caddis and 'other' from subsequent treatment groups ( $>24 \mathrm{~h}$ exposure) were not significantly different $(p<0.05)$ from each other. Pair-wise comparisons of densities of all taxa groups and biomass of midge were mixed, revealing few significant differences $(\mathrm{p}<0.05)$ between subsequent treatment groups (Appendix 5).

Also, the mean weight of individuals was significantly different $(p<0.004)$ between exposure treatment groups for the midge taxa group, but not for the caddis $(\mathrm{p}<0.17)$ and 'other' $(\mathrm{p}<0.30)$ groups (Appendix 6). The average weight of individual midges generally decreased on substrates exposed for longer duration (Figure 15). In addition, the artificial substrate community composition changed drastically with greater frequency and duration of de-watering. The midge taxa group comprised an increasingly higher proportion by density and biomass of the brick substrate community with increasing duration of exposure for the first several treatments. However, midges did not continue to increase in percent composition of the community for the treatment groups exposed for longer duration (>168 h; Table 6). Hydropsychidae and Psychomyiidae families of caddis, and ephemeropterans (mayflies) declined the most drastically among invertebrates from the Locke Island treatment substrates.

\section{F-Island}

We collected a total of 145 brick artificial substrates at F-Island (Site 5); 32 substrates were not used because of considerable movement and in some cases 
subsequent loss of strands or substrates. Forty-six brick samples were never de-watered and therefore considered control substrates for comparison with subsequent exposure treatments. The number of bricks sampled and their exposure durations are given in Table 2.

Mean invertebrate density and biomass of all three taxa groups were significantly different $(\mathrm{p}<0.0001)$ between exposure treatment groups (Appendix 7). All taxa groups followed similar drastic decreases in density and biomass as Locke Island substrates (Figure 16). The number of individuals, as well as number of taxa and taxonomic diversity also declined with increasing frequency and duration of exposure to air (dewatering) on brick substrates (Table 7).

Least Squares Means pair-wise comparisons revealed no significant difference ( $\mathrm{p}$ $<0.05$ ) in midge density and midge and 'other' biomass between the control substrates and the first treatment group at F-Island (Appendix 5). However, significant differences $(\mathrm{p}<0.05)$ were found in caddis density and biomass and 'other' biomass between the control substrates and the first treatment group. After the initial decrease in density and biomass from control to the first treatment, biomass of caddis and 'other' from subsequent treatment groups ( $>24 \mathrm{~h}$ exposure) were not significantly different $(\mathrm{p}>0.05)$ from each other. Pair-wise comparisons of densities of all taxa groups and biomass of midge were mixed, revealing few significant differences $(\mathrm{p}<0.05)$ between subsequent treatment groups (Appendix 5).

At Site 5 (F-Island) I found a 16\% reduction in mean total invertebrate density and $48 \%$ reduction in mean total biomass between the first treatment group substrates (1$24 \mathrm{~h}$ exposure) and the control substrates. Substrates exposed during more than $361 \mathrm{~h}$ of 
the test period (treatment F) experienced about a 99\% reduction in total invertebrate density and biomass relative to the control substrates. Also, the mean weight of individual caddis $(\mathrm{p}<0.04)$ and 'other' $(\mathrm{p}<0.0001)$ was significantly different between exposure treatment groups, but not significantly different for the midge group $(\mathrm{p}<0.17$; Appendix 6). The average weight of individual caddis and 'other' invertebrates generally decreased on substrates exposed for longer durations.

The community composition on artificial substrates at the F-Island site also changed drastically with higher frequency and duration of de-watering. The midge taxa group comprised an increasingly higher proportion of the brick substrate community by density and biomass from the control substrates to the exposure treatments exposed up to 72 hours. The average density of midges actually increased from the control substrates to the first treatment group on F-Island substrates. Invertebrate taxa which declined most drastically on the F-Island treatment substrates included: Hydropsychidae, ephemeropterans (mayflies), and Gastropoda (snails). In addition, both oligochaetes and arachnids (water mites) actually showed higher densities on substrates exposed 1-24 h (treatment 1) relative to the control substrates (Table 7).

The control substrate community composition also was considerably different between the Locke Island (Site 4) and F-Island (Site 5) sites (Figure 17). Midges comprised a higher proportion of the community by density and biomass at Locke Island than F-Island. Conversely, the caddis and 'other' taxa groups comprised a higher proportion of the invertebrate community by density at F-Island than at Locke Island. Accordingly, the caddis group comprised a lower proportion of the invertebrate 
community by biomass at Site 4 (Locke-Island). I found the percent composition of the 'other' group by biomass was similar between sites (Figure 17).

\section{SHORT-TERM EFFECTS OF DEWATERING}

\section{Invertebrate Drift}

\section{Near-shore Drift}

Discharge from Priest Rapids Dam and water level elevations at our sampling station fluctuated drastically (Figure 12). During the first sampling period, discharge ranged from 4,500 to $6,000 \mathrm{~m}^{3} / \mathrm{sec}$ (98 to $156 \mathrm{Kcfs}$ ), resulting in up to 1.2 vertical $\mathrm{m}$ (4 ft) change in water level, and as much as $0.25 \mathrm{~m}(0.9 \mathrm{ft})$ change in water elevation per hour (Figure 19). During the second sampling period, discharge ranged from approximately 2,600 to $4,400 \mathrm{~m}^{3} / \mathrm{sec}$ (125 to $267 \mathrm{Kcfs}$ ), resulting in up to 2.1 vertical m (7 $\mathrm{ft})$ change in water level, and as much as $1.3 \mathrm{~m}(4.25 \mathrm{ft})$ change in water elevation per hour.

ANCOVA model results revealed there was no significant effect of changes in discharge and subsequent water levels on either caddis $(p=0.19)$ or 'other' drift density $(p=0.06)$. I found a significant effect of discharge and subsequent water level on midge drift density ( $p=0.008$; Appendix 8), with increased midge drift density as discharge and water levels increased and decreased density as discharge and water levels dropped (Figure 20). However, this pattern did not occur within the caddis and 'other' groups.

In addition, I found a significant effect $(\mathrm{p}<0.0001)$ of net collection depth on mean drift density for all three taxa groups (Appendix 8). Tukey-Kramer multiple comparisons revealed the deeper collection depths resulted in significantly higher drift 
densities $(\mathrm{p}<0.05)$ of both midge and 'other' taxa groups among net depths $(0.45,0.75$, and $1.0 \mathrm{~m}$; Figure 21), and only the 0.45 and $0.75 \mathrm{~m}$ depths did not have significantly different caddis drift densities $(\mathrm{p}=0.17)$.

Time of day (diel) had no significant effect on the mean drift density of midge ( $p$ $=0.22)$ and 'other' $(p=0.55)$ groups based on the ANCOVA model results. I found time of day did have a significant effect on the caddis drift density $(\mathrm{p}=0.005)$ (Appendix 8). Tukey-Kramer multiple comparisons revealed significantly different caddis drift densities during daytime $(p=0.003)$ and evening $(p=0.02)$ samples relative to night-time samples. Caddis drift density was lowest during daytime hours, higher during evening and morning hours, but the highest during the night (Figure 22).

\section{Boat Drift}

Water level elevations at our sampling station drift sampling from a boat fluctuated (Figure 23) up to $1.3 \mathrm{~m}$. (4.3 ft) vertical change in water level, and as much as $0.26 \mathrm{~m}(0.84 \mathrm{ft})$ change in water elevation per hour.

Results for the boat invertebrate drift were different from the nearshore sampling. I found no observable pattern in invertebrate drift density with changes in discharge and water levels (Figure 20). Discharge, depth, and time of day had no significant effects ( $p$ $>0.05$ ) on invertebrate drift for the boat sampling based on the ANCOVA model results (Appendix 9). Although not statistically significant, the midge taxa group attained slightly higher drift densities in the shallower $(1.5 \mathrm{~m})$ samples than the deeper $(2.1 \mathrm{~m})$ samples, but the caddis and 'other' groups occurred at higher densities in the deeper samples than the shallower (Figure 24). 
Midge drift density (Figure 25) only revealed a significant difference with respect to the effect of time of day ('diel'). Midge drift density was significantly higher during the daytime $(p=0.03)$ relative to nighttime samples based on Tukey-Kramer multiple comparisons. Although not statistically significant $(\mathrm{p}>0.05)$, caddis drift density was lowest during daytime hours, higher during evening and morning hours, and highest during the night.

\section{Proportion of Benthos in Drift}

Most benthic macroinvertebrates taxa occurred in the drift in similar proportions as they occurred on the substrates. However, comparison of the average macroinvertebrate community composition found in drift samples with the composition on natural substrates revealed several distinct differences (Figure 26). The invertebrate drift community was comprised by a much higher proportion of taxa from the 'other' group. Several organisms comprised a higher portion of the drift community but were not collected on artificial substrates only (larval fish, zooplankton, Collembola, and Corixidae hemipteran insects). Midges, hydropsychids (caddisflies), and oligochaetes comprised slightly lower proportions of the drift community as did the kick screen composition, whereas aquatic arachnids (water mites), ephemeropterans (mayflies), and psychomyids (caddisflies) occurred in slightly higher proportions in the drift than the natural substrate community composition (Figure 26). 


\section{Artificial Exposures}

Effects of short-term artificial exposures to air on the artificial substrate community revealed rapid and substantial decreases in invertebtate taxa survival with longer durations of exposure. Lab-processed samples showed a significant effect of exposure treatment $(\mathrm{p}<0.0001)$ on the average mortality rate of all three invertebrate taxa groups for each treatment (Appendix 10). The mortality rate increased nearly exponentially with longer duration of exposure to air (Figure 27). Mean survival of midge, caddis, and 'other' taxa dropped to 79, 82, and 92\%, respectively, with 1 hour of exposure to air. Survival continued to decline with longer duration of exposure, with less than $55 \%$ of all taxa surviving 8 hours of exposure to air.

I also found differences in invertebrate mortality between artificial substrate types. I found a significant difference in average mortality rate between substrates (brick and tile) for both the caddis $(\mathrm{p}=0.04)$ and 'other' $(\mathrm{p}=0.02)$ taxa groups, but no significant difference between substrate types for the midge group $(p=0.22)$. The caddis and 'other' taxa incurred a higher average mortality rate on the tile substrates than the brick substrates above them for all exposure durations (Figure 27), while the midge exhibited no such pattern. I also found a significant interaction between substrate type and treatment group for both the caddis $(\mathrm{p}=0.03)$ and 'other' $(\mathrm{p}=0.009)$ groups. However, upon further investigation, results from an analysis of simple effects (i.e., - the two separate parts of the interaction term) found a remaining significant effect of treatment exposure on the average mortality of caddis on brick and tile substrates $(\mathrm{p}<$ $0.0001)$ as well as 'other' on brick $(\mathrm{p}<0.0006)$ and tile substrates $(\mathrm{p}<0.0001$; Appendix 11). The mean survival of all taxa groups generally decreased with longer exposure 
duration for both substrates (Figure 27); however, the caddis group experienced the poorest survival among taxa groups followed by the midge and then 'other' groups.

The relative mobility of each taxa group varied substantially among exposure treatment duration; however, all groups exhibited a general trend of higher mobility with increasing duration of exposure (Figure 28). The caddis group demonstrated the highest mobility during all exposure treatments followed by midges and then the 'other' group. The proportion of mobile invertebrates varied from approximately 24,14 , and $13 \%$ during the 30 minute exposure to as much as 75,42 , and $31 \%$ for caddis, midge, and 'other' groups, during the 6 hour exposure, respectively.

The mean survival of all taxa groups on the field-checked samples generally decreased with longer exposure duration for both substrates (Figure 29), and incurred lower survival than exhibited on the laboratory-checked samples. The caddis group experienced the poorest survival among taxa groups, followed by midge and then 'other'. The proportion of invertebrates which moved off brick substrates and onto the tile surface below experienced lower survival than those which did not migrate. The proportion of invertebrates which migrated onto the tile surfaces varied from approximately 32,20 , and $8 \%$ during the 30 min exposure to as much as 83,75 , and $94 \%$ for caddis, midge, and 'other' groups, respectively, during the 7 hour exposure. The proportion that migrated between exposure treatment durations on the field-processed samples was more variable than the invertebrate migration documented on the laboratory processed substrates. I found no trend of higher movement off the brick substrates (mobility) with increasing duration of exposure, except for the caddis group. The caddis group generally demonstrated the highest mobility during all exposure treatments (Figure 28). 


\section{DISCUSSION}

\section{LONG-TERM EFFECTS OF DEWATERING}

Our results clearly show that benthic macroinvertebrates were severely reduced in density and biomass and experienced altered community structure with increasing duration of exposure. Total invertebrate density was approximately four times higher on substrates always watered than on substrates exposed from 1-24 hours (first exposure treatment). Gislason (1985) also found macroinvertebrates were limited by the frequency and duration of de-watering. He reported densities 1.8 to 59 times higher under stable flows than during fluctuating flows at corresponding depths, a result of hydropeaking in the Skagit River, Washington. Substrates exposed during more than 361 hours of our entire test period experienced about a $99 \%$ reduction in total invertebrate density and biomass relative to the control substrates at both sites.

Invertebrate biomass was also severely affected, with the mean total invertebrate biomass reduced by $65 \%$ on bricks exposed only 1-24 hours during the entire 3-week test period. Drastic reductions in biomass $(76 \%)$ also were found as a result of severe flow fluctuations on the Sturgeon River, Michigan (Evans 1979). In the Upper Kennebec River, Maine, Trotzky and Gregory (1974) determined that extreme water level fluctuations decreased density and biomass of most benthic invertebrates, with only Alloperla sp.stonefly nymphs and midges present in substantial abundance, suggesting their tolerance to the wide variations in flow.

Some benthic macroinvertebrates were able to tolerate some exposure to air, while others were not. We found a reduction in all macroinvertebrate taxa with 
increasing duration of exposure with the exception of midges. Midges actually occurred at higher densities on substrates exposed 1-24 hours compared to the substrates never dewatered (controls) at F-Island (Site 5). Therefore, midges may be able to tolerate exposure periods at or less than 24 hours without appreciable declines in density. Fisher and LaVoy (1972) also found invertebrate communities in the Connecticut River, Massachussetts, to tolerate cummulative exposure to air up to $13 \%$ of the time without significant change. Our results also reveal that exposure to air affects caddis and 'other' groups more drastically than midges. In fact, midges comprised a larger proportion of the samples with increasing duration of exposure. Many researchers (Fisher and LaVoy 1972; Trotzky and Gregory 1974; Ward 1976; Gislason 1985; Haber and Brusven 1982) have consistently observed increases in either the relative abundance or percent community composition of the Chironomidae family of dipteran insects in peaking flow regimes downstream of hydroelectric dams.

Invertebrate diversity also decreased with increasing duration of exposure. In Colorado, Powell (1958) found similarly high biomass and lower diversity at regulated sites (below reservoir) than unregulated sites (above reservoir). The invertebrate diversity present in the Hanford Reach is already sparse, an observation consistent with other regulated waters (Radford and Hartland-Rowe 1971; Ward 1976; Armitage 1978; Munn and Brusven 1987). Therefore, the further reductions in diversity we observed are not suprising.

The average biomass of individual invertebrates also generally decreased on artificial substrates exposed for longer duration. The average weight of the midge at Site 4 , and caddis and 'other' groups at Site 5 were significantly different among exposure 
treatments. Decreased average size of macroinvertebrates with longer exposure suggests that smaller individuals are either first to recolonize previously de-watered areas or less mobile and remain when water levels recede yet still avoid desiccation.

Several factors presumably influence the effects water level fluctuations have on macroinvertebrate communities under the hydropeaking flows present in the Hanford Reach, Columbia River. Changes in microhabitat conditions may be the largest determinant in invertebrate response to these fluctuations. Although our artificial substrates likely reduced the inherent variability and patchiness in invertebrate densities and distribution, the composition of the surrounding natural substrates still varied between sites and even within sites, possibly influencing localized community structure.

Effects of changes in discharge on benthic invertebrates is also likely influenced by several micro-habitat scale factors such as the slope of the shoreline, water velocity, and depth. The slope of the shoreline affects not only the area of substrate inundation for a given time interval, but also positively correlates with water velocity and depth, which have large influences on macroinvertebrate distribution and density. In addition, algal communities have been shown to become desiccated and die under fluctuating flows (Kroger 1973; Blinn et al. 1995), and since many invertebrates feed on algae and associated bacteria and fungi, their numbers could be expected to be limited by the scarcity of attached periphyton. Brusven et al. (1974) found that productive algal zones provided higher survival during dewatering and higher habitat complexity not present in the upper zone of fluctuation.

Although the artificial substrate invertebrate community experienced drastic declines with increased exposure duration, I believe this shoreline benthic invertebrate 
community in the Hanford Reach has stabilized and probably supports the more tolerant and specialized taxa which can survive these fluctuations in discharge. Valentin et al. (1995) found less diverse and more specialized macroinvertebrate communities in reaches affected by frequent flow fluctuations on the Fontauliere River, France.

Stoneflies (Plecoptera) were never found in any of our samples from the Hanford Reach although the physical habitat appears suitable for these macroinvertebrates. Moog (1993) found Plecoptera were especially sensitive to hydropeaking, which was related to asphyxiation and desiccation in dewatered areas. In contrast, in the Upper Kennebec River, Maine, Trotzky and Gregory (1974) found Alloperla sp.stonefly nymphs abundant under conditions of extreme water level fluctuations. Stoneflies were last documented in the Hanford Reach prior to the construction of Priest Rapids Dam (Robeck et al. 1954). However, the hypothesis that stoneflies were once common and are now absent is highly speculative since Robeck et al.'s sampling was not replicated and it was the only pre-dam data found. I believe hydro-peaking flows may have eliminated stoneflies from the Hanford Reach long ago.

Net-building trichopterans such as those in the Hydropsyschidae family have remained in the Hanford Reach in substantial numbers despite the fluctuations in discharge. Other scientists have found that large numbers of filter-feeding organisms, particularly Hydropsychidae, have persisted in hydropeaking flow regimens (Cushing 1963; Spence and Hynes 1971; Brusven and Trihey 1978). Conversely, Radford and Hartland-Rowe (1971) found substantial numbers of net-building caddis in preimpoundment samples in the Kananaskis River in Alberta, yet following impoundment 
and hydropeaking operations they were rare and only collected during stable flow periods.

Taxonomic diversity was similar between the Locke-island Site (most upstream) and F-island Site (downstream) artificial substrate invertebrate communities. In contrast, Gore (1977) found that diversity in the Tongue River, Montana generally increased slowly with distance downstream from the Tongue River Reservoir Dam. Diversity would be expected to increase downstream according to the serial discontinuity concept developed by Ward and Stanford (1995), because water level fluctuations are substantially dissipated with increasing distance from Priest Rapids Dam. However, our sites are probably sufficiently close to each other to experience the same relative changes in discharge and water levels, which may explain the only slight difference in diversity between sites. The already sparse invertebrate diversity present in the Hanford Reach may also exacerbate the small differences in diversity as well as the the broad generalizations inherent in calculating 'taxonomic' diversity as opposed to 'speciesbased' diversity indices.

The methods and locations of sampling for the long-term effects of the dewatering objective were determined based on results from preliminary sampling during the summer of 1998. Preliminary sampling provided crucial sample size and variance estimates which helped optimize and statistically validate additional test objectives. Our findings from preliminary sampling revealed that the Hanford Reach benthic macroinvertebrate community on artificial substrates was comprised of mainly chironomids and several caddisfly taxa, mainly Hydropsychidae. These findings corroborate those found previously in the Hanford Reach from both grab and artificial 
substrate samples (Page and Nietzel 1977a, 1977b, 1978, 1979; Page et. al. 1979; Nietzel 1996), and community composition was also similar to samples collected prior to the construction of Priest Rapids Dam. Robeck et al. (1954) found a benthic macroinvertebrate community dominated by midges and caddisfly, and with a higher component of Mollusks than found in our artificial substrate samples. Psychomyia spp. caddisfly larvae were the only benthic macroinvertebrate collected which had not been previously reported in the Hanford Reach (Page and Nietzel 1977a, 1977b, 1978, 1979; Page et.al. 1979; Nietzel 1996).

Although other studies used different collection methods, our findings demonstrate a high abundance of benthic macroinvertebrates on artificial substrates not exposed by water level fluctuations in the Hanford Reach, Columbia River. The average total density $\left(27,600 / \mathrm{m}^{2}\right)$ I found was nearly four times higher than the average total density $\left(7,470 / \mathrm{m}^{2}\right)$ reported by Robeck et al. (1954) in the same area of the Hanford Reach, Columbia River. However, differences in densities may, in part, be a result of the use of artificial substrates as opposed to Surber samples taken by Robeck et al. (1954) from the natural substrates. The mean benthic macroinvertebrate density I found is also high relative to more recent studies in other medium to large rivers in the Pacific Northwest. Gislason (1985) reported maximum densities of 16,800 macroinvertebrates $/ \mathrm{m}^{2}$ from (modified Surber samples) in the Skagit River, Washington, whereas Brusven et. al. (1974) found 6,490 macroinvertebrates $/ \mathrm{m}^{2}$ in grab samples from the Hells Canyon Reach the Snake River, Idaho. Gore (1977) found 5,350 macroinvertebrates $/ \mathrm{m}^{2}$ in Hess samples from the Tongue River, Montana. 
Colonization on artificial substrates was highly variable both between and within substrates, colonization periods, and among sites. These highly variable communities may have been affected both directly by the water level fluctuations and indirectly by microhabitat differences in velocity, depth, and substrate composition. Substrates were placed at depths below predicted lowest water levels during the colonization periods. Unfortunately, some substrates were unexpectedly exposed because water levels dropped below predicted levels. However, our large sample sizes (60/site) allowed us to discard substrates that appeared desiccated, and still have sufficient replicates to allow valid statistical comparisons. Furthermore, our larger number of replicates (30/site) compared to other studies $(<5)$, allowed us to determine the density to within $+/-25 \%$ accuracy of the true mean.

The combination of site, colonization, and substrate was determined which required the least number of samples to maintain sufficient precision in estimating the true mean density of all three macroinvertebrate taxa groups (Table 8). The combination of brick artificial substrates colonized for 4 weeks at Site 2 was selected to assess effects of water level changes during year-2 tests. Although the combination of barbecue basket substrates colonized for 4 weeks at Site 2 required lesser samples to accurately estimate the true mean, we selected brick substrates because they were colonized at significantly lower densities and would provide the same precision for far less effort to process samples.

Results from the assessment of long-term effects of water level fluctuations on benthic macroinvertebrates revealed several important community dynamics, but 
assessment on a shorter time-scale provided even greater insight into the response of the communitiy to these severe diel disturbances.

\section{SHORT-TERM EFFECTS OF DEWATERING}

\section{Drift}

We found invertebrate drift generally increased with respective increases in discharge; however, this pattern was only evident in shallow nearshore samples. Many other researchers have also documented (Minshall and Winger 1968; Pearson et.al. 1968; Radford and Hartland-Rowe 1971) increases in drift density with increased discharge. High drift density occurring during increases in discharge suggests the physical removal or 'catastrophic drift' of some benthic macroinvertebrates. Midges appear to have catastrophically drifted with increases in discharge. Although drift density was usually higher after dark, similar to the diel periodicity found by many other researchers (Waters 1962; Elliott 1965; 1969; Elliott and Minshall 1968), drift density also was high during daytime hydropeaking water level changes. Anderson and Lehmkuhl (1968) also found high daytime drift densities as a result of powerpeaking discharges. Drifting invertebrates are likely being entrained in the rising water outside of their natural diel drift periodicity windows. Minshall and Winger (1968) found that water level changes induced invertebrates to enter the drift during daytime, outside their normal behavioral response at night. Conversely, a decrease in discharge can cause drift to increase since macroinvertebrates seek to escape dewatering. If the discharge decreases too rapidly, then stranding of macroinvertebrates may occur (Brusven et al. 1974). However, midges 
were found at low densities in the drift with dropping water levels, suggesting they may be incurring substantial stranding.

I also found substantial differences in drift densities between taxa groups, with higher midge drift densities than either caddis or 'other' (mostly mayflies) densities for both sampling methods over all discharges. I did not find any significant effect of discharge on the drift of caddis or 'other' groups, which suggests lower susceptibility of caddis compared to midges to physical removal or entrainment during increasing discharges and water levels. Caddis and 'other' groups may be more actively entering the drift during dropping discharges and water levels mainly because of low velocities. Many invertebrates have adapted to a rather limited range of velocities or depths of water (Fraser 1972), and therefore may actively (catastrophically) enter the drift to find preferred velocities as discharge decreases. Caddisfly larvae, particularly several netspinning species of the Hydropsychidae family, occur at preferred water velocities to allow water movement to bring food into their nets (Phillipson 1954; Edington 1968; Boon 1978). The majority of caddis found in our samples were filter-feeding hydropsychids. Therefore, many of these invertebrates may be entering the drift with changes in water levels to find adequate conditions for feeding as well as to avoid dewatering.

Drift densities in the Hanford Reach may not be increasing and decreasing with increases and decreases in discharge for several reasons. Many invertebrates may have become adjusted to the frequent disturbances from hydropeaking discharges. Perry and Perry (1986) suggested that many invertebrates had become adjusted to the frequent changes in discharge due to hydropeaking in the Flathead River downstream of Hungry 
Horse Reservoir, Montana. Although boat sampled drift densities were considerably higher than from shallower nearshore samples, we found no significant effect of discharge, sample depth, or time of day on invertebrate drift density from boat sampling. Drift response may have been further complicated by delayed catastrophic drifting because of the strong overriding influence of light as a triggering mechanism on drift even with drastic changes in discharge during daylight (Brusven et al. 1974).

The vertical distribution of invertebrate drift may not be equal throughout the water column. Matter and Hopwood (1980) found Baetidae mayflies and Hydrophyschidae caddisflies accumulated disproportionately in the upper and lower portions of the water column, in the Mississippi River, Minnesota. Our drift samples were collected at or near the bottom, thereby likely capturing most hydropsychid caddis drift.

Macroinvertebrate populations constantly fluctuate because of benthos redistribution (Townsend and Hildrew 1976). This redistribution or recolonization of macroinvertebrates has four main sources: downstream drift, upstream migration along the bottom, vertical migration within the substrate, and aerial recolonization from mature adults (Williams and Hynes 1976). We assessed drift to determine how invertebrate populations were repsonding to fluctuations in discharge, water level, and velocity.

The fluctuations in flow and the subsequent drift that follows may be adversely affecting the benthic community. Layzer et. al. (1989) found that fluctuations created macroinvertebrate communities impoverished in species richness and density. Water level fluctuations can also cause macroinvertebrates to drift when fish are active, potentially further diminishing species richness and/or density of the invertebrate 
community (Minshall and Winger 1968). These fluctuations in discharge and subsequent water levels may actually provide increased food availability to fish during daylight hours when invertebrate drift is traditionally low relative to historic unregulated discharge. Yet, this hypothesized net loss in productivity of benthic invertebrates due to desiccation and loss of available habitat likely offsets potential increases in food (invertebrate) availability.

Our long-term test results suggest the macroinvertebrate populations in shoreline areas of the Hanford Reach, Columbia River where most water level fluctuations take place, are substantially reduced by diel changes in discharge, and therefore may be potentially impacting fish which feed on these invertebrates. Due to differences in current velocity and availability of shelter, invertebrate numbers are typically higher at the edges of large streams than at the center (Hynes 1970). Smaller chinook salmon juveniles live in the margins of streams and avoid the higher current velocities in deeper water (Gislason 1985). Several studies have found that fluctuations in flow can cause the stranding and reduction of fish-food organisms and young fish, thus reducing rearing capacity (Powell 1958; Phillips 1969). Studies on the upper Snake River, Idaho and Wyoming, found that resultant de-watering of benthic habitats not only caused substantial exposure and death to aquatic invertebrates, but this destruction of food organisms was also found to have detrimental effects on higher trophic levels (Kroger 1973). If macroinvertebrate abundance were reduced in the margins, then it could potentially affect chinook salmon that live and feed in the margins.

Even under the extreme fluctuations in water levels and velocity, macroinvertebrates have remained at relatively high densities and biomass in the Hanford 
Reach of the Columbia River. In addition, juvenile chinook salmon are found in good condition with full stomachs and achieve excellent growth rates. Moreover, Becker (1970) considered most insect forms to have been floating, drifting, or swimming in the water column when captured by chinook salmon fry, thereby possibly making the dynamics of invertebrate drift also important with stranding and loss of available habitat in considering the trophic effects of water level fluctuations.

\section{Artificial Exposures}

Short-term exposure tests revealed a dramatic decrease in survival with even short exposure durations. Survival of midge and 'other' taxa groups dropped to 50\% with $1 \mathrm{hr}$ of exposure. Although highly variable, the survival of invertebrates generally continued to decline with increased duration of exposure. Many studies have found losses of invertebrates caused by decreasing discharges from power generating plants causing stranding (Fisher and LaVoy 1972; Kroger 1973; Becker et. al. 1981; Extence 1981; Corrarino and Brusven 1983) and desiccation (Powell 1958; Pearson et.al. 1968) of macroinvertebrates in shallow shoreline areas. Brusven et. al. (1974) found appreciable stranding and mortality due to desiccation of caddisflies (Trichoptera) and mayflies (Ephemeroptera). They also found that chironomid dipterans (midge) demonstrated remarkable survival after as much as 96 hours; however, their study was conducted in March when cool weather usually prevails, a factor highly favorable for survival. Conversely, the atmospheric conditions during our artificial exposure tests were quite harsh because of sustained winds, despite cooler than normal late summer temperatures $\left(21^{\circ} \mathrm{C}\right)$. In addition, a significant interaction between substrate type and treatment for 
caddis and 'other' groups likely occurred because the mortality of both was higher on the tile than on the bricks.

I found that a large proportion of the invertebrates exposed quickly migrated vertically to avoid desiccation. These macroinvertebrates, which moved to the underside of the brick and onto the tile surface below, are likely the component which, on natural substrates, either move vertically under gravel and rocks into the wetted substrate, or migrate with the receding water to avoid desiccation. Williams and Hynes (1976) found that many species of invertebrates migrate down into the interstitial spaces of the substrate (hyporheic zone) to depths up to $100 \mathrm{~cm}$ in streams with deep gravel beds. Williams (1981) found that many benthic invertebrates migrate laterally within the substrate. Other invertebrates, such as the caddisfly Cheumatopsyche (Hydropsychidae family), have been found to persist or even flourish under hydropeaking discharges because they burrow into the substrate during lower water levels (Trotzky and Gregory 1974; Brusven and MacPhee 1976; Brusven and Trihey 1978; Ward and Short 1978). Extence (1981) also indicated that uncased (relatively mobile) caddisfly larvae were relatively resistant to stranding mortality. Our tile surfaces served only as a relative index of potential vertical movement and escapement from desiccation; however, natural substrate sampling would likely quantify this macroinvertebrate migratory component more accurately.

I also found, with nearly every consecutive hourly exposure to air, a higher proportion of caddis moved than 'other', and more 'other' than midge. Again, caddisfly larvae, particularly several net-spinning species of the Hydropsychidae family, are likely seeking preferred water velocities for feeding as well as to avoid desiccation. We found 
midges were the least mobile taxon, yet the most numerous and also relatively tolerant to exposure. Cases of some caddisflies may reduce the chances of larvae either being able to migrate fast enough to avoid desiccation or being transported by the current. Extence (1981) suggested that many caddis larvae would be unlikely to colonize recently inundated areas of substrates and would therefore, be partially protected from stranding. Brusven and MacPhee (1976) attributed improved exposure tolerance of cased caddisflies to the protection afforded by their case. However, under natural conditions, I suggest most invertebrates will likely move to and congregate in small depressions of water or moist shaded areas which eventually dessicate, resulting in death of most organisms.

Stranding susceptibility, tolerance to exposure, and ability of aquatic insects to migrate with the receding water levels depends on a variety of factors, including the substrate type, the slope of the shoreline, atmospheric conditions, taxonomic differences, and the rate of recession (Ward 1992). For example, higher temperatures and wind result in faster evaporation and, therefore, faster desiccation of dewatered substrates. The mobility and resultant susceptablility of benthic invertebrates may be heavily influenced by the life history stages of the various species present during certain times of the year. We found the smaller and less mobile early instars of midges and mayflies incurred higher mortality. White et al. (1985) found appreciably higher stranding of invertebrates on dewatered substrate in the fall than spring, mainly because of their smaller size and reduced mobility in the fall. Perry and Perry (1986) found that more insects were stranded during a faster rate of decrease in discharge. Our exposure tests were artificially created, thus dewatering occurred much faster than the hydropeaking-induced changes in discharge and subsequent dewatered substrates. 
We found some macroinvertebrates were able to tolerate brief periods of exposure without significant change, however losses incurred over the broad range of diel fluctuations likely result in the reduction of total benthic invertebrate abundance. Several other researchers have found short-term tolerance to exposure by some invertebrates. However, they also concluded the same overall result, that of reduced total invertebrate densities with the failure to maintain minimal low flows (Minshall and Winger 1968; Fisher and LaVoy 1972). Diel fluctuations in water levels may also prevent the establishment of "natural" macroinvertebrate communities on periodically exposed areas. Several authors have found a given area of substrate requires approximately 4 weeks to reestablish a normal carrying capacity of invertebrates (Mason et al. 1967; Coleman and Hynes 1970; Williams and Hynes 1976). However, taxa such as midges, which are numerically dominant in the Hanford Reach, have exceptionally short generation times, continuous reproduction throughout the year, rarity of diapause, and presence of aerial adults (Meffe and Minckley 1987) that may enable rapid and effective recolonization of these macroinvertebrates even under diel changes in water levels.

An investigation of fluctuating flows downstream of Dworshak Dam on the Clearwater River, Idaho, found that daily water fluctuations did not promote short-term colonization in shore zones of fluctuation (Brusven and Trihey 1978). Later research by Gersich and Brusven (1981) confirmed this observation; they found that benthos required more time to colonize habitats in rapidly varying flows than in unregulated flows (66 vs 47 days). Brusven and MacPhee (1976) determined that stoneflies, caddisflies, and mayflies do not readily colonize shore regions in a daily state of fluctuation; however, Chironomidae did inhabit these areas. Our long-term results corroborate these findings, 
since midges comprised a higher proportion of the macroinvertebrate community on substrates exposed for longer durations. Perry and Perry (1986) reported slower recovery of biotic communities in lotic ecosystems with daily fluctuations than in systems with less frequent fluctuations. Brusven et al. (1974) suggested that prolonged dewatering of the Hell's Canyon reach of the Snake River reduced primary production, causing a lag in recolonization of invertebrates when conditions again became favorable.

Reduction in the amplitude and/or frequency of flow fluctuations from hydropeaking operations of Priest Rapids Dam will likely have substantial effects on the macroinvertebrate community in the Hanford Reach, Columbia River. Dampened flow fluctuations may allow some reestablishment of a native and more diverse macroinvertebrate community. Reduced flow fluctuations, particularly during critical salmonid rearing periods, could potentially enhance invertebrate biomass. In addition, peaking discharges during nighttime hours would result in a more naturalized drift pattern and less desiccation due to lower air temperatures and evaporation than daytime fluctuations.

Many studies indicate that fluctuating flows more severely impact the density and abundance of benthic invertebrates than fish (Kroger 1973; Brusven and McPhee 1976; and Haber et al. 1978). Most benthic invertebrates are less mobile and more likely to encounter problems maintaining position or attachment on substrate during changes in discharge. Therefore, it may be that under dynamic flow conditions of varying intensity and duration, such as peaking hydropower, minimum available habitat over a short period of time may need to be evaluated rather than the availability of optimum conditions considered by instream flow incremental methodolgy evaluations (Gore 1989). 
Benthic macroinvertebrate and fish populations in the Columbia River evolved to tolerate a spring spate, followed by relatively stable late-summer and fall flows; however, the hydroelectric flow regime has created an entirely artificial annual hydrograph with extensive daily fluctuations in discharge into the Hanford Reach (Becker et. al. 1981). Extensive flow variations due to hydroelectric peaking operations of Priest Rapids Dam, similar to those evaluated in this study, alter the macroinvertebrate community in the Hanford Reach of the Columbia River, Washington beyond that of the natural hydrograph. 


\section{SUMMARY}

- Macroinvertebrates colonized both brick and barbecue basket artificial substrates at high densities during preliminary sampling in August and September, 1998, averaging 27,600 invertebrates $/ \mathrm{m}^{2}$ in the Hanford Reach, Columbia River.

- Benthic macroinvertebrate fauna was low in diversity and dominated by Chironomidae (midges) and Trichoptera (caddisfly) larvae, comprising $87 \%$ of the community by density.

- Barbecue baskets colonized significantly higher density and biomass of benthic macroinvertebrates than brick artificial substrates. Brick artificial substrates colonized for 4 weeks were selected to assess effects of water level changes during year-2 (1999) sampling, because they most efficiently provided the needed precision.

- Benthic macroinvertebrates found on substrates periodically exposed by water level fluctuations were severely limited in density and biomass compared to the communities on continually inundated control substrates. Substrates exposed from 124 hours during the 30-day test period experienced an average 59\% and $65 \%$ reduction in total invertebrate density and biomass, respectively.

- Chironomidae (midges) were the only invertebrates that tolerated up to 24 hours of exposure to air during the 30-day test period without declines in density, and comprised a higher proportion of the invertebrate community with longer durations of exposure to air. 
- Midge density in shallow $(<1 \mathrm{~m})$ drift nets increased with discharge and rising water levels and decreased with decreasing discharge and dropping water levels, although this pattern was not statistically significant for the 'other' and caddis categories.

- Changes in discharge and water levels catastrophically entrained macroinvertebrates into the drift outside of behavioral diel periodicity.

- Artificial exposure tests revealed that the survival of macroinvertebrates on substrates exposed to air decreased dramatically with increasing duration of exposure, with only $50 \%$ survival after 1 hour of exposure.

- A large proportion of invertebrates exposed to air quickly migrated to avoid desiccation, but smaller and less moblile early instars of midges incurred higher mortality.

- Results of long- and short-term studies of dewatering on artificial substrates, indicate water level fluctuations affect near-shore community structure, density, and biomass of macroinvertebrates in the Hanford Reach, Columbia River. 


\section{REFERENCES}

Anderson, N.H, and D.M. Lehmkuhl. 1968. Catastrophic drift of insects in a woodland stream. Ecology 49: 198-206.

Armitage, P.D. 1978. Downstream changes in the composition, numbers, and biomass of bottom fauna in the Tees below Cow Green Reservoir and in an unregualted tributary Maize Beck, in the first five years after impoundment. Hydrobiologia 58: $145-156$.

Bauersfeld, K. 1978. Stranding of juvenille salmon by flow reductions at Mayfield Dam on the Cowlitz River, 1976. Technical Report No. 36, State of Washington, Department of Fisheries, Olympia, Washington, USA.

Becker, C.D. 1970. Feeding bionomics of juvenile chinook salmon in the central Columbia River. Northwest Science. 44(2): 75-81.

Becker, C.D., D.H. Fickeisen, and J.C. Montgomery. 1981. Assessment of impacts from water level fluctuations on fish in the Hanford Reach, Columbia River. PNL-3813, Pacific Northwest Laboratory, Richland, Washington, USA.

Benfield, E.F., A.C. Hendricks, and J. Cairns Jr. 1974. Proficiencies of two artificial substates in collecting stream macroinvertebrates. Hydrobiologia 45(4): 431440 .

Blinn, D.W., J.P. Shannon, L.E. Stevens, and J.P. Carder. 1995. Consequences of fluctuating discharge for lotic communities. Journal of the North American Benthological Society. 14(2): 233-248.

Boon, P.J. 1978. The preimpoundment distribution of certain Trichoptera larvae in the north Tyne River systems (northern England) with particular reference to current speed. Hydrobiologia. 57: 167-174.

Brusven, M.A. and C. MacPhee. 1976. The effect of river fluctuations resulting from hydroelectric peaking on selected aquatic invertebrates and fish. Research Technical Completion Report, Project A-035-IDA. Idaho Water Resources Research Institute, University of Idaho, Moscow, Idaho, USA.

Brusven, M.A., C. MacPhee, and R. Biggam. 1974. Effects of water fluctuation on benthic insects. Pages 67-79 in: Anatomy of a river. Pacific Northwest Basins Commission Report, Vancouver, Washington, USA.

Brusven, M.A. and E.F. Trihey. 1978. Interacting effects of minimum flow and fluctuating shorelines on benthic stream insects. Research Technical Completion Report. Project No. A-052-IDA. Idaho Water Resources Research Institute. Moscow, Idaho, USA. 
Coleman, M.J. and H.B.N. Hynes. 1970. The vertical distribution of the invertebrate fauna in the bed of a stream. Limnology and Oceanography. 15: 31-40.

Corrarino, C.A. and M.A. Brusven. 1983. The effects of reduced stream discharge on insect drift and stranding of near shore insects. Freshwater Invertebrate Biology. 2(2) :88-98.

Cushing, C.E. 1963. Filter-feeding insect distribution and planktonic food in the Montreal River. Transactions of the American Fisheries Society. 92: 216-219.

Cushman, R.M. 1985. Review of ecological effects of rapidly varying flows downstream from hydroelectric facilities. North American Journal of Fisheries Management 5: 330-339.

Dauble, D.D., R.H. Gray, and T.L. Page. 1980. Importance of insects and zooplankton in the diet of 0 -age Chinook salmon in the central Columbia River. Northwest Science 52(2): 108-109.

Eckblad, J.W. 1991. Biologist's Toolbox: How many samples should be take? BioScience. 41(5): 346-348.

Edington, J.M. 1968. Habitat preferences in net-spinning caddis larvae with special reference to the influence of water velocity. Journal of Animal Ecology. 37: 675692.

Elliott, J.M. 1965. Daily fluctuations of drifting invertebrates in a Dartmoor stream. Nature 205: 1127-1129.

Elliott, J.M. 1969. Diel periodicity in invertebrate drift and the effect of different sampling periods. Oikos 20:524-528.

Elliott, J.M. and G.W. Minshall. 1968. The invertebrate drift in the River Duddon, English Lake District. Oikos 19: 39-52.

Evans, E.D. 1979. Estimating stream macrobenthos benefits from low flow augmentation. Pages 491-495 in Mitigation Symposium: a national workshop on mitigating losses of fish and wildlife habitats. General Technical Report RM-65. U.S. Department of Agriculture, Rocky Mountain Forest and Experiment Station, Fort Collins, Colorado, USA.

Extence, C.A. 1981. The effect of drought on benthic invertebrate communities in a lowland river. Hydrobiologia 83: 217-224.

Fisher, S.G. and A. LaVoy. 1972. Differences in littoral fauna due to fluctuating water levels below a hydroelectric dam. Journal Fisheries Research Board of Canada 29(10): 1472-1476.

Fraser, J.C. 1972. Regulated discharge and the stream environment. Pages 263-285 in River Ecology and Man: Proceedings of an International Symposium on River Ecology and the Impact of Man. Academic Press, New York, New York, USA.

Gersich, F.M. and M.A. Brusven. 1981. Insect colonization rates in near-shore regions subjected to hydroelectric power peaking flows. Journal of Freshwater Ecology 1: 231-236. 
Gislason, J.C. 1985. Aquatic insect abundance in a regulated stream under fluctuating and stable diel flow patterns. North American Journal of Fisheries Management 5: 39-46.

Gore, J.A. 1977. Reservoir manipulations and benthic macroinvertebrates in a prarie river. Hydrobiologia 55: 113-123.

Gore, J.A. 1989. Models for predicting benthic macroinvertebrate habitat suitability under regulated flows. Pages 253-265 in Alternatives in Regulated River Management. Eds. J.A. Gore and G.E. Petts. CRC Press, Inc. Boca Raton, Florida, USA.

Haber, D.F., Moore, B., and Hicks, W. 1978. A review of the impacts of fluctuating flows on the lower Clearwater River and recommendations for future studies. Idaho Water Resources Reseach Institute. Moscow, USA.

Haber, D.F. and M.A. Brusven. 1982. The use of invertebrate indicators for ecological resiliency evaluation of a flow regulated river. Research Technical Completion Report, Project B-049-IDA. Idaho Water and Energy Resources Research Institute, University of Idaho, Moscow, Idaho, USA.

Hynes, H.B.N. 1970. The ecology of running waters. University of Toronto Press, Toronto, Canada.

Johnson, R.K., T. Wiederholm, and D.H. Rosenberg. 1993. Freshwater biomonitoring using individual organisms, populations, and species assemblages of benthic macro-invertebrates. Pages 40-125 in D.H. Rosenberg and V.H. Resh, editors Freshwater Biomonitoring and Benthic Macroinvertebrates. Routledge, Chapman \& Hall, New York, New York, USA.

Kroger, R.L. 1973. Biological effects of fluctuating water levels in the Snake River, Grand Teton National Park, Wyoming. American Midland Naturalist 89: 478481.

Layzer, J.B., T.J. Nehus, W. Pennington, J.A. Gore, and J.M. Nestler. 1989. Seasonal variation in the composition of the drift below a peaking hydroelectric project. Regulated Rivers: Research \& Management. 3: 29-34.

Mason, W.T., J.B. Anderson, and G.E. Morrison. 1967. A limestone-filled artificial substrate sampler-float unit for collecting macroinvertebrates in large streams. Progressive Fish Culturist 29: 74.

Mason, W.T., Jr. and P.P. Yevich. 1967. The use of phloxine B and rose bengal stains to facilitate sorting benthic samples. Transactions of the American Microscopic Society 86(2): 221-223.

Matter, W.J. and A.J. Hopwood. 1980. Vertical distribution of invertebrate drift in a large river. Limnology and Oceanography 25(6): 1117-1121. 
Meffe, G.K. and W.L. Minckley. 1987. Persistence and stability of fish and invertebrate assemblages in a repeatedly disturbed Sonoran Desert strream. American Midland Naturalist. 117: 177-191.

Minshall, G.W. and P.V. Winger. 1968. The effect of reduction in stream flow on invertebrate drift. Ecology. 49: 580-582.

Moog, O. 1993. Quantification of daily peak hydropower effects on aquatic fauna and management to minimize environmental impacts. Regulated Rivers: Research \& Management. 8: 5-14.

Munn, M.D. and M.A. Brusven. 1987. Discontinuity of trichopteran (caddisfly) communities in regulated waters of the Clearwater River, Idaho USA. Regulated Rivers: Research \& Management. 1: 61-69.

Neitzel, D.A. (Editor). 1996. Hanford Site National Environmental Policy Act (NEPA) Characterization. Pacific Northwest Laboratories. Richland, Washington, USA.

Nightengale, T.L. 1999. Assessment of the benthic community on hard substrate in three lower Snake River reservoirs. M.S. Thesis, University of Idaho, 118 p.

Page, T.L., and D.A. Neitzel. 1977a. Seasonal and relative abundance of Columbia River macro-benthos near WNP 1,2, and 4 from October 1974 to September 1975. Pages 4.1-4.12 in Aquatic ecological studies conducted near WNP 1,2 and 4, September 1974 through September 1975. WPPSS Columbia River Ecology Studies Volume 2. Battelle Pacific Northwest Laboratories. Richland, Washington, USA.

Page, T.L., and D.A. Neitzel. 1977b. Seasonal and relative abundance of Columbia River macro-benthos near WNP 1,2, and 4 from October 1975 to February 1976. Pages 4.1-4.9. in Aquatic ecological studies conducted near WNP 1,2 and 4, September 1974 through September 1975. WPPSS Columbia River Ecology Studies Volume 3. Battelle Pacific Northwest Laboratories. Richland, Washington, USA.

Page, T.L., and D.A. Neitzel. 1978. Columbia River macrobenthos near NP 1,2, and 4 from March through December 1976. Pages 4.1-4.14 in Aquatic ecological studies conducted near WNP 1,2 and 4, September 1974 through September 1975. WPPSS Columbia River Ecology Studies Volume 4. Battelle Pacific Northwest Laboratories. Richland, Washington, USA.

Page, T.L., D.A. Neitzel. 1979. Columbia River benthic macrofauna and microflora near WNP 1,2, and 4: January through December 1977. Pages 4.1-4.36 in Aquatic ecological studies conducted near WNP 1,2 and 4, January through December 1977. WPPSS Columbia River Ecology Studies Volume 5. Battelle Pacific Northwest Laboratories. Richland, Washington, USA.

Page, T.L., D.A. Neitzel, and R.W. Hanf. 1979. Columbia River benthic macrofauna and microflora near WNP 1,2, and 4: January through August 1978. Pages 4.1-4.27 in Aquatic ecological studies conducted near WNP 1,2 and 4, January through August 1978. WPPSS Columbia River Ecology Studies Volume 6. Battelle Pacific Northwest Laboratories. Richland, Washington, USA. 
Pearson, W.D., R.H. Kramer, and D.R. Franklin. 1968. Macroinvertebrates in the Green River below Flaming Gorge Dam, 1964-65 and 1967. Proceedings of the Utah Academy of Science, Arts, \& Letters 45: 148-167.

Perry, S.A., and W.B. Perry. 1986. Effects of experimental flow regulation on invertebrate drift and stranding in the Flathead and Kootenai Rivers, Montana, USA. Hydrobiologia. 134: 171-182.

Philipson, G.N. 1954. The effect of water flow and oxygen concentrations on six species of caddisfly (Trichoptera). Proceedings of the Zoological Society of London. 124: 547-564.

Phillips R.W. 1969. Effect of unusually low discharge from Pelton Regulating Reservoir, Deschutes River, on fish and other aquatic organisms. Oregon State Game Commission, Basin Investigations Sect., Spec. Rept. No. 1, 39p.

Powell, G.C. 1958. Evaluation of the effects of a power dam water release pattern upon the downstream fishery. M.S. Thesis, Colorado State University, 149 p.

Radford, D.S. and R. Hartland-Rowe. 1971. A preliminary investigation of bottom fauna and invertebrate drift in an unregulated and a regulated stream in Alberta. Journal of Applied Ecology. 8: 883-903.

Resh, V.H. and D.M. Rosenberg. 1989. Spatial-temporal variability and the study of aquatic insects. Canadian Entomologist. 121: 941-963.

Richmond, M.C. and W.A. Perkins. 1998. MASS1 (Modular Aquatic Simulation System 1D): A one-dimensionsl hydrodynamic and water quality model for river systems. Pacific Northwest National Laboratory Draft Report. Battelle Hydrology Group. 29pp.

Robeck, G.G., C. Henderson, and R.C. Palange. 1954. Water quality studies on the Columbia River. US Department of Health, Education, and Welfare. Public Health Service. Cincinnati, Ohio, USA.

Rosenberg, D.M., and V.H. Resh. 1982. The use of artificial substrata in the study of freshwater benthic macroinvertebrates. Pages 175-235 in J. Cairns Jr., editor. Artificial substrata. Ann Arbor Science, Ann Arbor, Michigan, USA.

Ruggles, C.P. and W.D. Watt. 1975. Ecological changes due to hydroelectric development on the Saint John River. Journal Fisheries Research Board of Canada 32: 161-170.

SAS Institute. 1996. SAS, Version 6.1. SAS Institute, Cary, North Carolina, USA.

Spence, J.A. and H.B.N. Hynes. 1971. Differences in benthos upstream and downstream of an impoundment. Journal of the Fisheries Research Board of Canada 28: 3543.

Townsend, C.R. and A.G. Hildrew. 1976. Field experiments on the drifting, colonization and continuous redistribution of stream benthos. Journal of Animal Ecology. 45: 759-772. 
Trotzky, H.M. and R.W. Gregory. 1974. The effects of water flow manipulation below a hydroelectric power dam on the bottom fauna of the Upper Kennebec River, Maine. Transactions of the American Fisheries Society 103: 318-324.

Valentin, S., J.G. Wasson, and M. Phillippe. 1995. Effects of hydropower peaking on epilithon and invertebrate community trophic structure. Regulated Rivers: Research \& Management 10: 105-119.

Vannote, R.L., G.W. Minshall, K.W. Cummins, J.R. Sedell, and C.E. Cushing. 1980. The river continuum concept. Canadian Journal of Fisheries and Aquatic Sciences. 37: 130-137.

Ward, J.V. 1976. Effects of flow patterns below large dams on stream benthos: a review. Pages 235-253 in J.F. Orsborn and C.H. Allman, editors. Instream flow needs symposium, Volume 2. American Fisheries Society, Bethesda, Maryland, USA.

Ward, J.V. 1992. Water level, current, and discharge. Pages 275-289 in Aquatic Insect Ecology - Biology and Habitat. John Wiley \& Sons, Inc., New York, New York, USA.

Ward, J.V. and R.A. Short. 1978. Macroinvertebrate community structure of four special lotic habitats in Colorado, USA. Verhandlungen Internationale Vereinigung Limnologie 20: 1382-1387.

Ward, J.V. and J.A. Stanford. 1983. The intermediate disturbance hypothesis: an explanation for biotic diversity patterns in lotic ecosystems. Pages 347-356 in T.D. Fontaine, III and S.M. Bartell, editors. Dynamics of lotic ecosystems. Ann Arbor Press, Ann Arbor, MI.

Ward, J.V. and J.A. Stanford. 1995. The serial discontinuity concept: extending the model to floodplain rivers. Regualted Rivers: Research \& Management 10: 159168.

Waters, T.F. 1962. Diurnal periodicity in the drift of stream invertebrates. Ecology 43: 316-320.

White, R.G., A.E. Bingham, J.H. Milligan, M.A. Brusven, and C.A. Corraino. 1985. Effects of reduced stream discharge on fish and aquatic macroinvertebrate populations phase II. Research Technical Completion Report. Idaho Water Resources Research Institute, University of Idaho, Moscow.

Williams, D.D. 1981. Migrations and distributions of stream benthos. Pages 155-207 in M.S. Lock and D.D. Williams, editors. Perspectives in Running Water Ecology. Plenum Press, New York, New York, USA.

Williams, D.D. and H.B.N. Hynes. 1976. The recolonization mechanisms of stream benthos. Oikos 27: 265-273. 


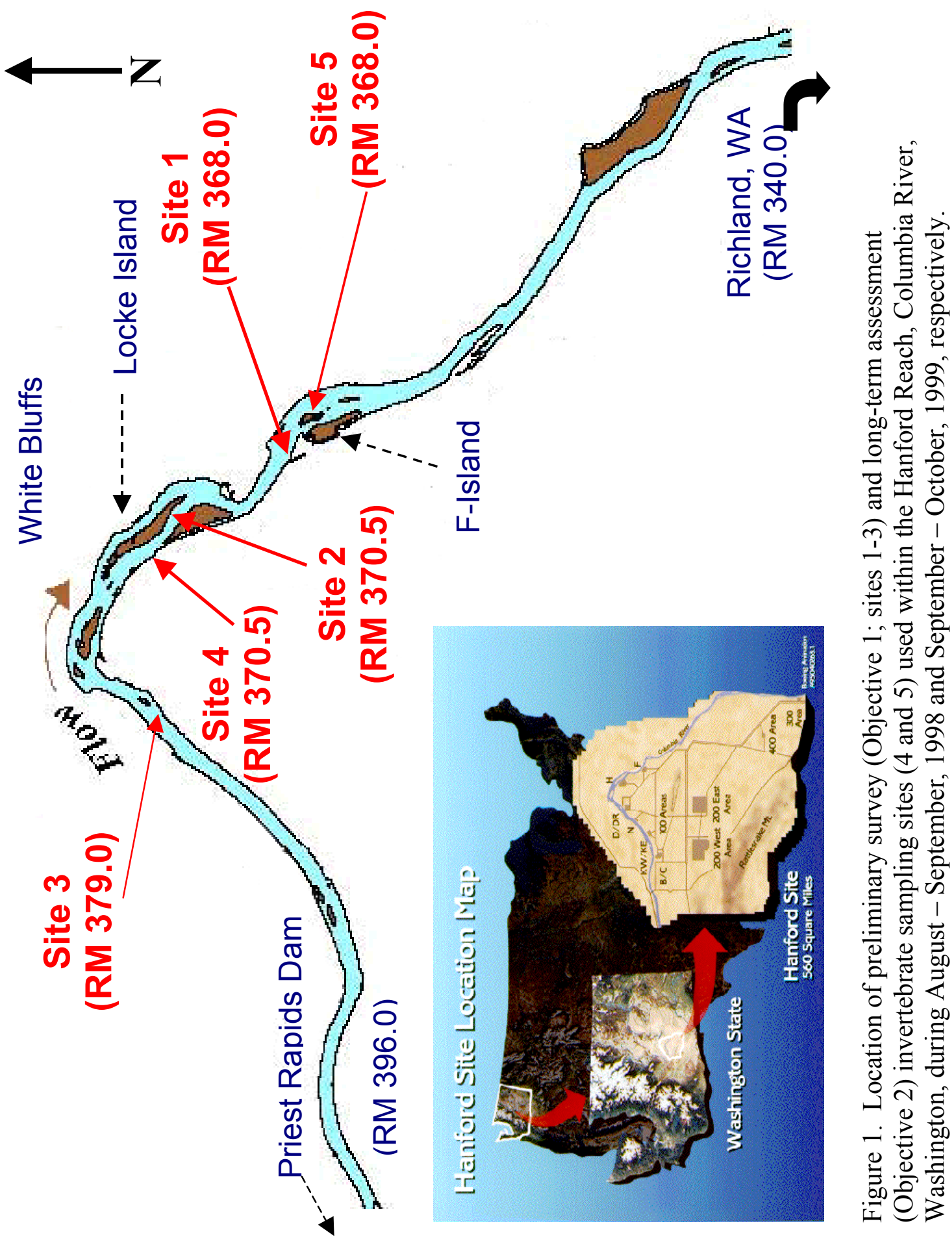




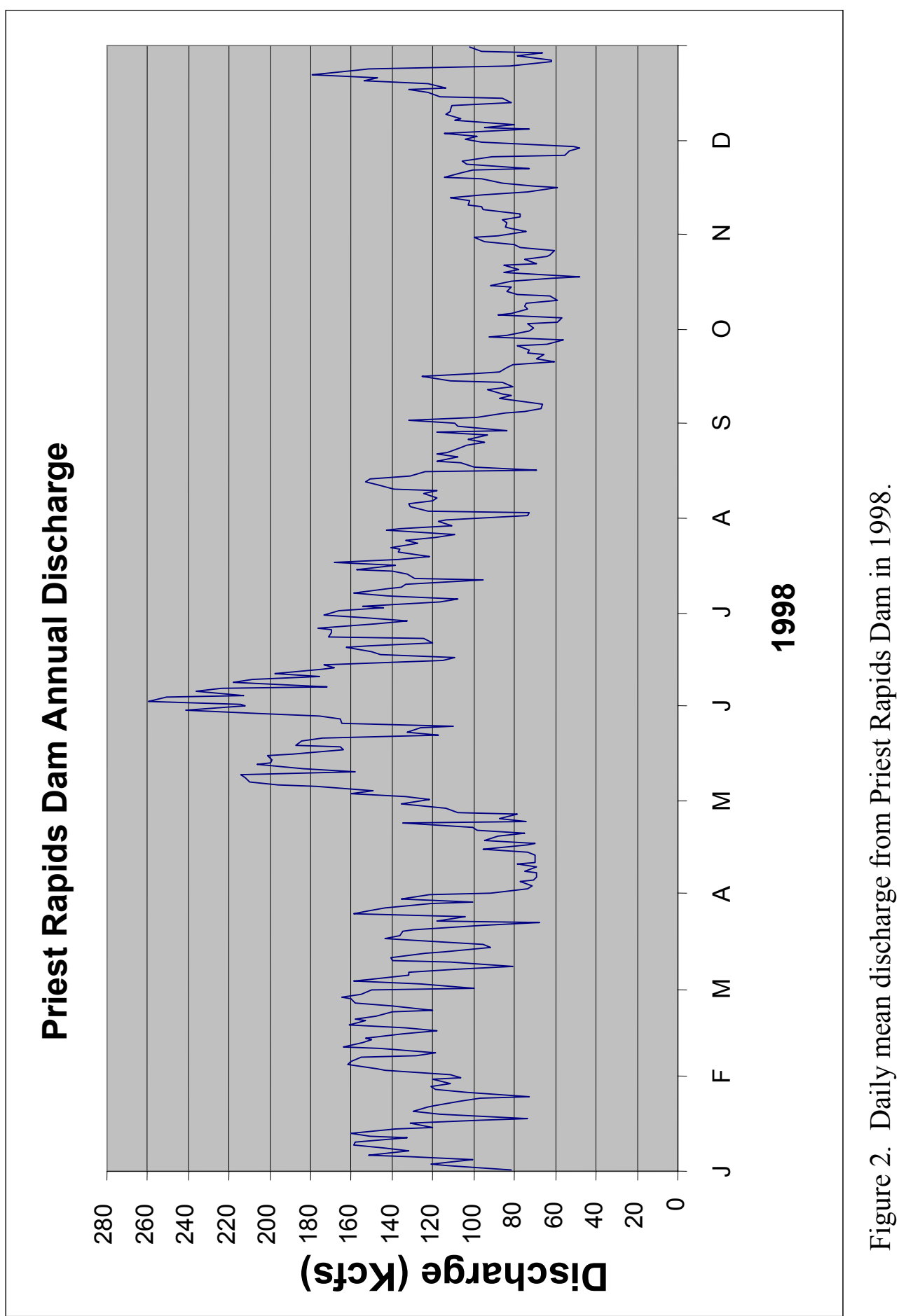



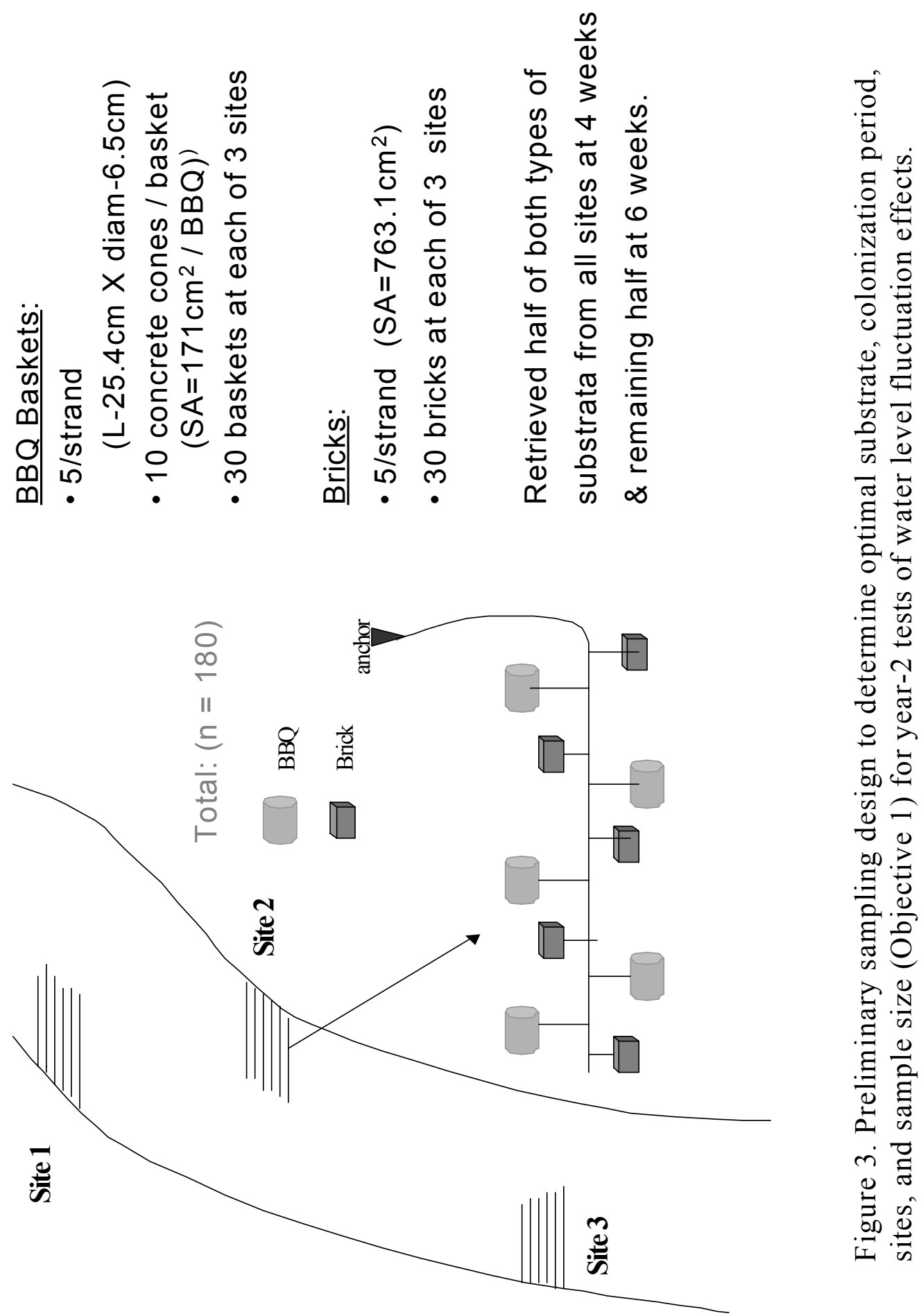

嗢

$\Xi \pm$

$\overline{0} \sim$

ठ

$\circ>$

ธี ڤี

ज्ञ

- 0

00.

=

․․ㅇ

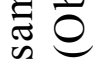

를

ํㅣㄹ

竜

는

$\dot{\theta}$

() त

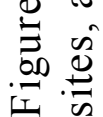




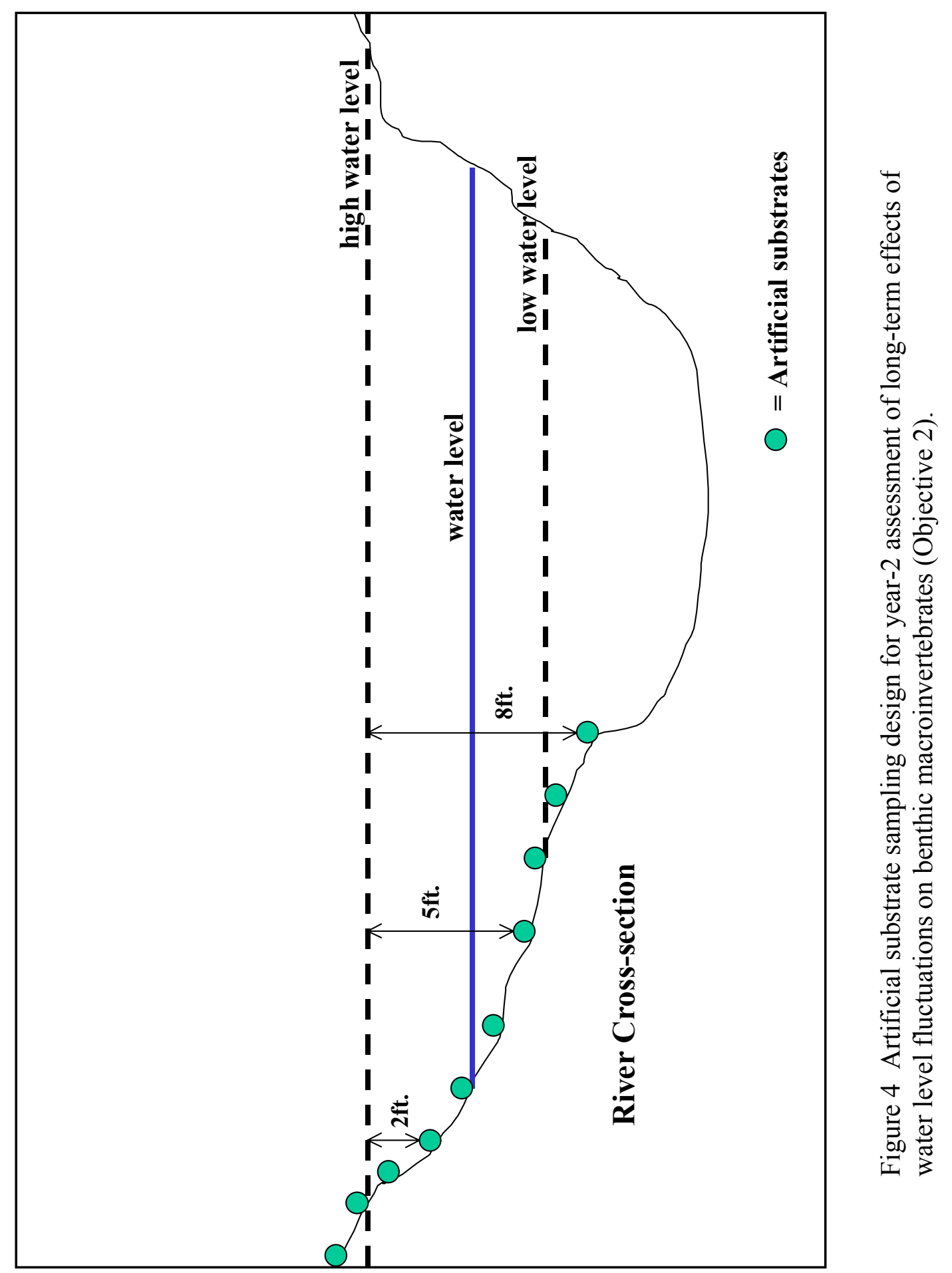



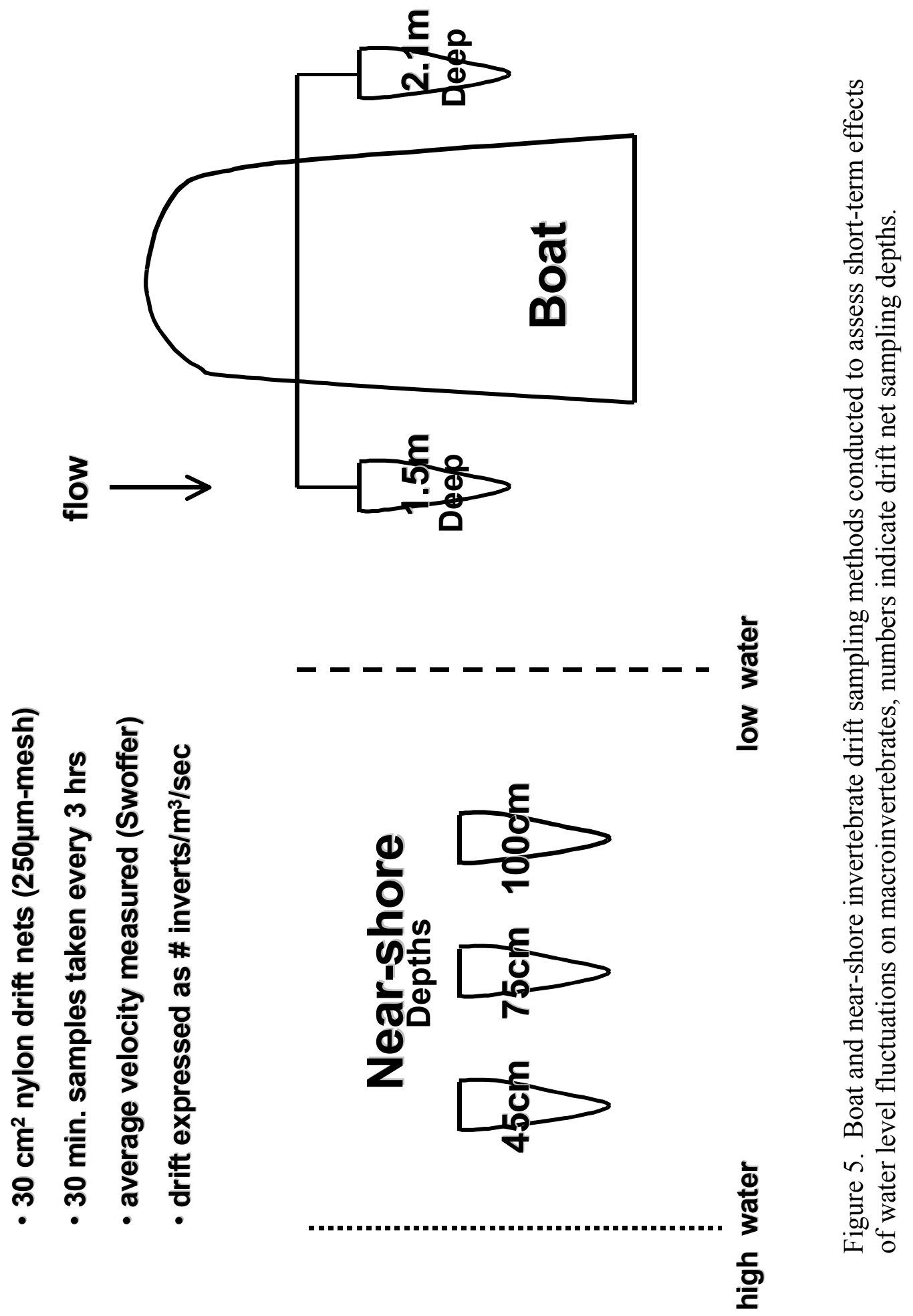


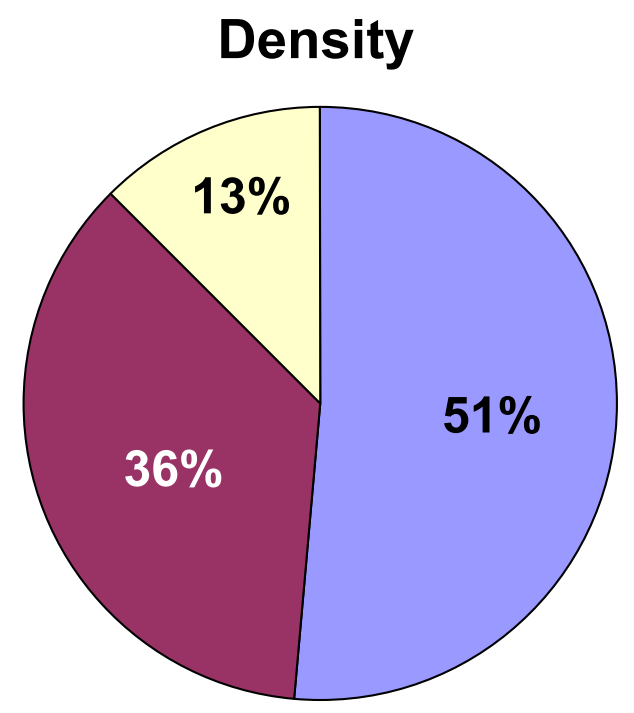

\section{Biomass}

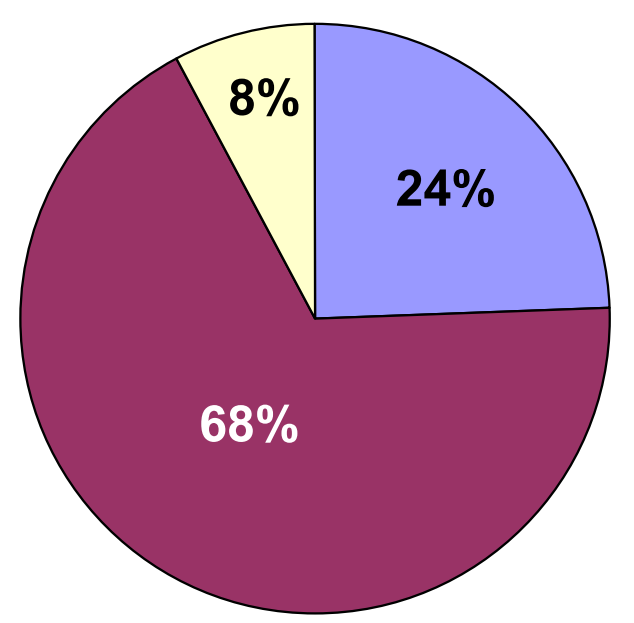

\section{$\square$ Midge $\square$ Caddis $\square$ Other}

Figure 6. Mean proportional density and biomass of benthic macroinvertebrates collected from 12 August to 23 September, 1998 on all preliminary survey artificial substrates in the Hanford Reach, Columbia River, Washington. 


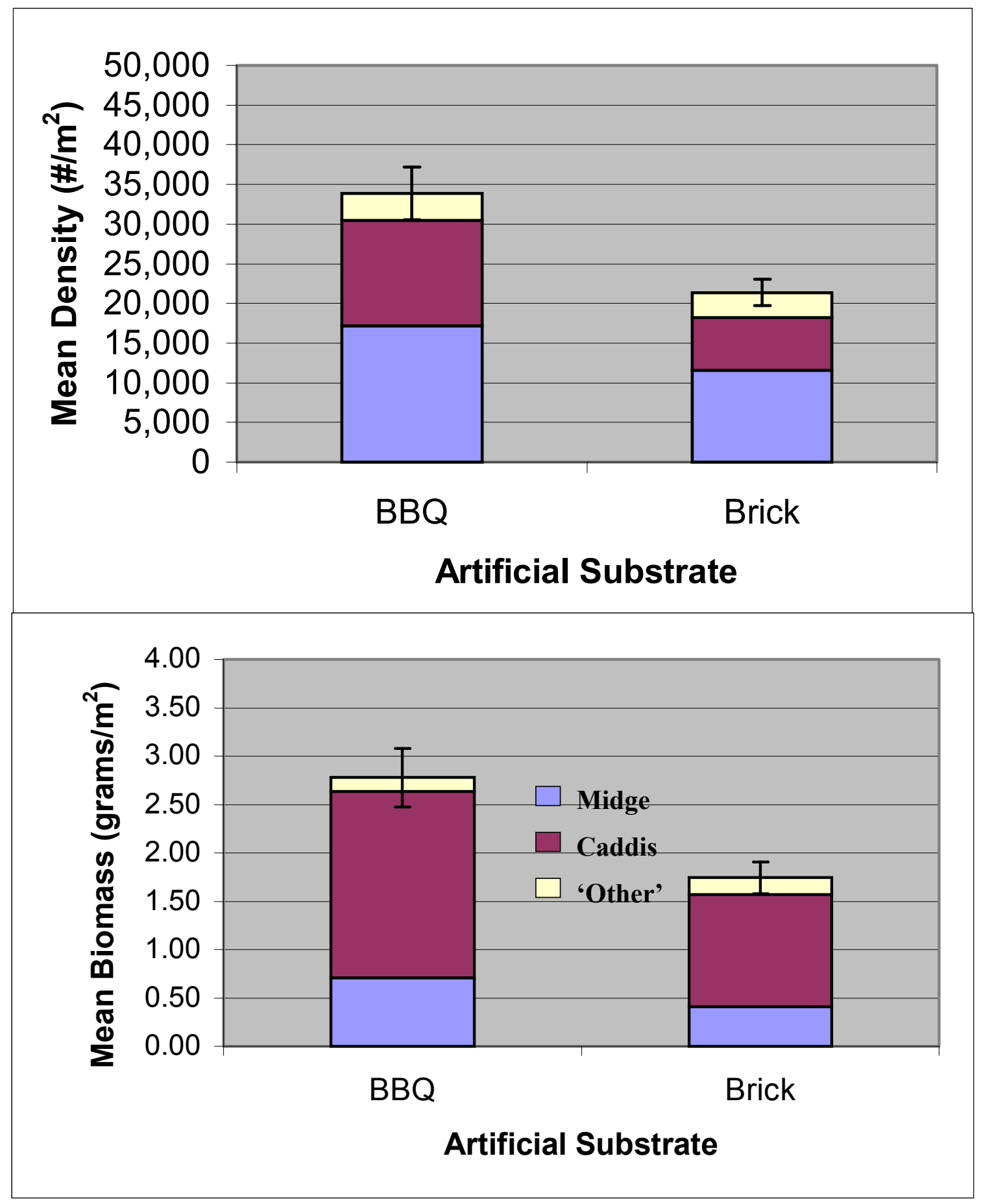

Figure 7. Mean density and biomass of midge, caddis, and 'other' taxa categories of macroinvertebrates collected on barbecue basket (BBQ) and brick artificial substrates in the Hanford Reach, Columbia River, Washington, from 12 August to 23 September, 1998. Vertical error bars represent (+/-) one standard error of the total density and biomass. 

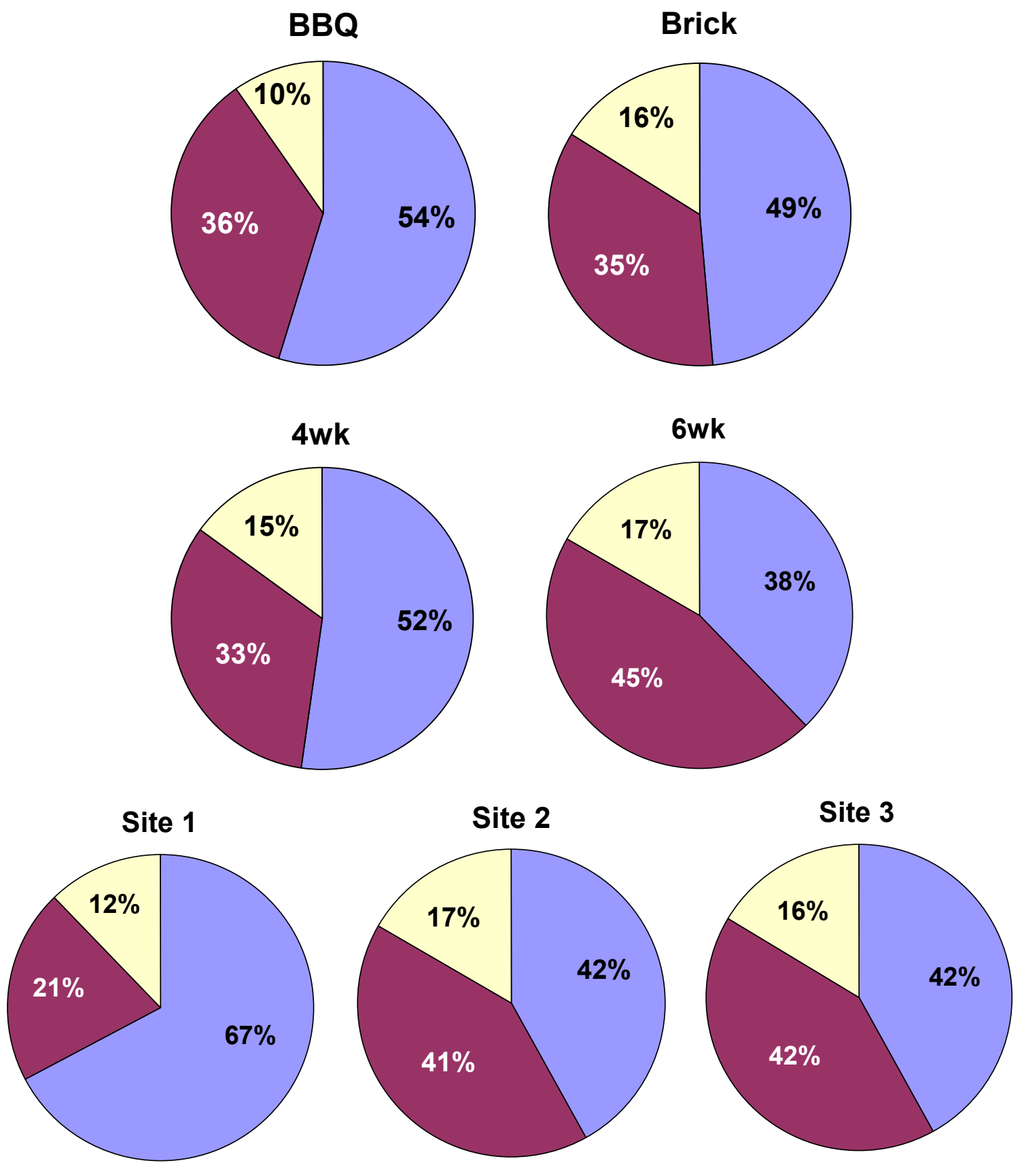

\section{$\square$ Midge $\square$ Caddis $\square$ Other}

Figure 8. Mean proportional density of benthic macroinvertebrates collected from barbecue basket (BBQ) and brick artificial substrates for 4 or 6 weeks at River Mile (RM) 360.5 (Site 1); RM 370.5 (Site 2); and RM 375.0 (Site 3) in the Hanford Reach, Columbia River, Washington, from 12 August to 23 September, 1998. 

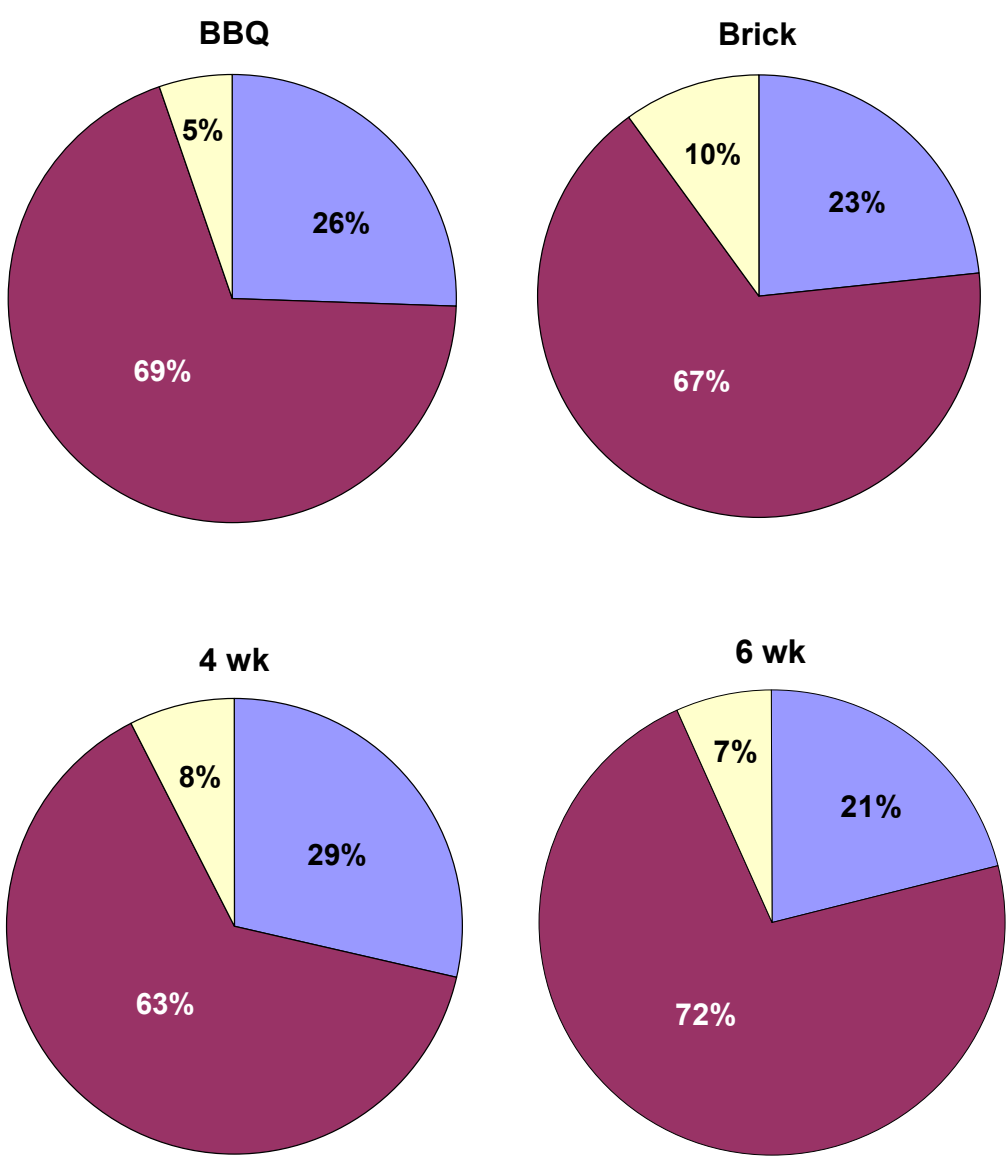

Site 1
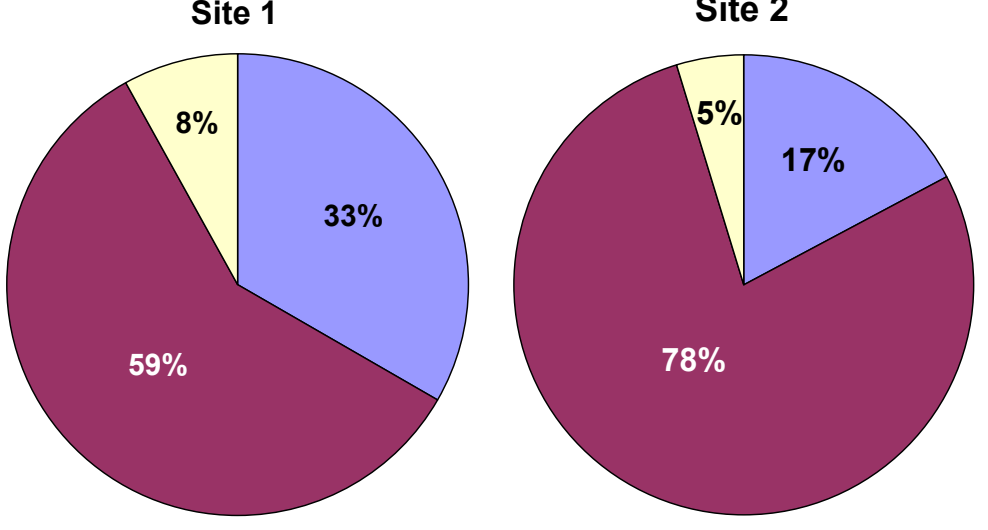

$\square$ Midge $\square$ Caddis $\square$ Other
Site 3

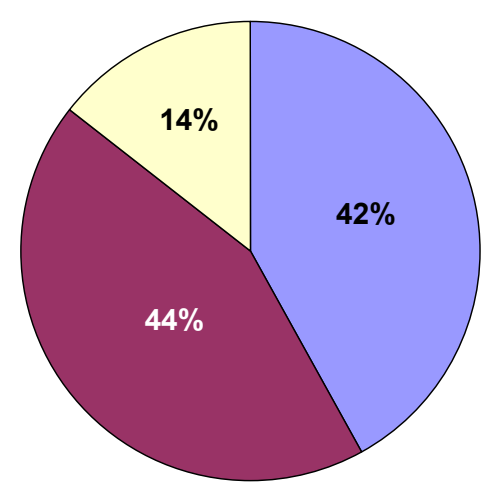

Figure 9. Mean proportional biomass of benthic macroinvertebrates (Mollusk weights excluded) collected from barbecue basket (BBQ) and brick artificial substrates colonized for 4 or 6 weeks at River Mile (RM) 360.5 (Site 1); RM 370.5 (Site 2); and RM 375.0 (Site 3) in the Hanford Reach, Columbia River, Washington, from 12 August to 23 September, 1998. 


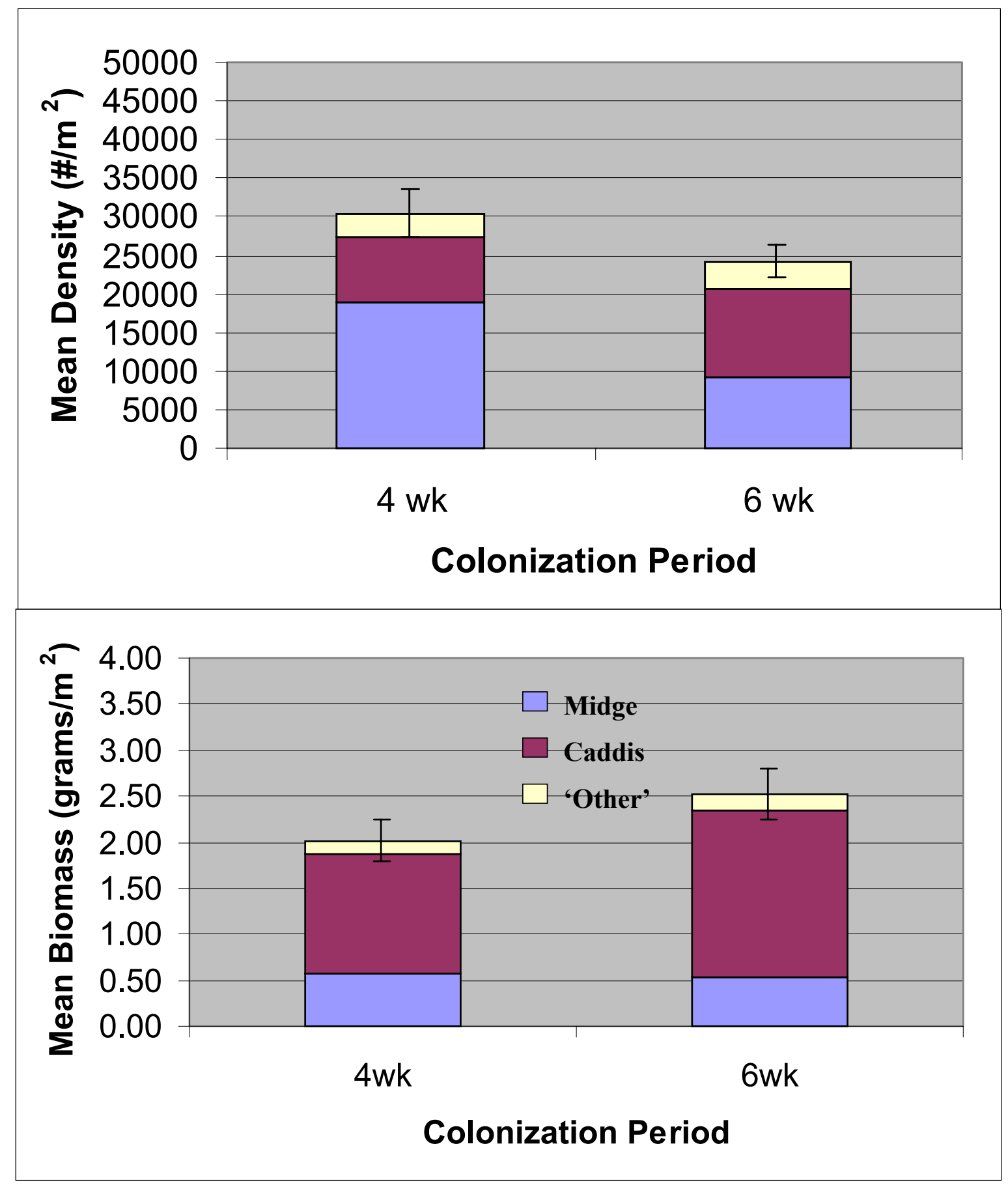

Figure 10. Mean density and biomass of midge, caddis, and 'other' taxa categories of benthic macroinvertebrates collected on artificial substrates following 4 week or 6 week colonization periods in the Hanford Reach, Columbia River, Washington, from 12 August to 23 September, 1998. Vertical error bars represent $(+/-)$ one standard error of the total density and biomass. 


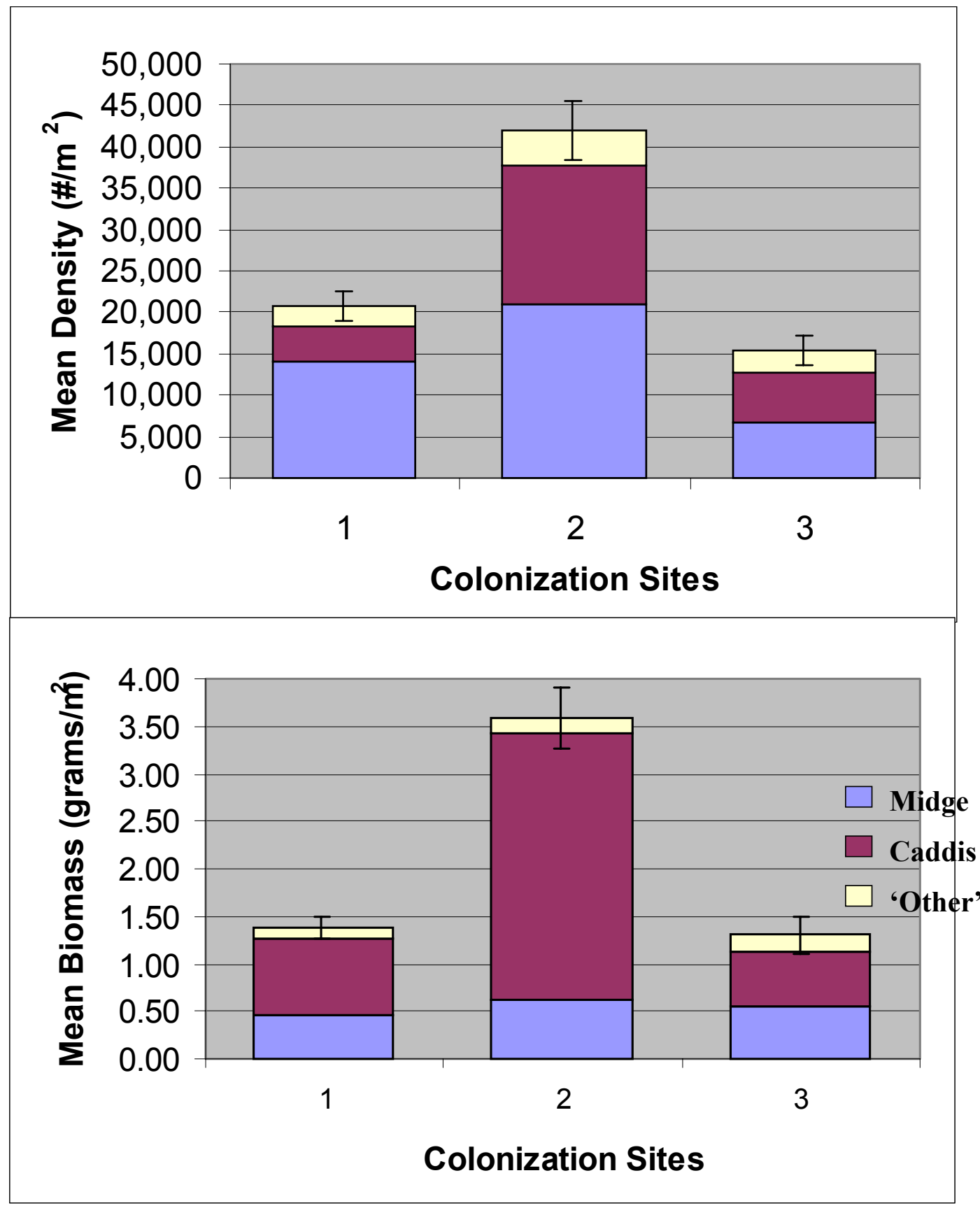

Figure11. Mean density and biomass of midge, caddis, and 'other' taxa categories of benthic macroinvertebrates collected on artificial substrates at River Mile (RM) 360.5 (Site 1); RM 370.5 (Site 2); and RM 375.0 (Site 3 ) in the Hanford Reach, Columbia River, Washington, from 12 August to 23 September. 1998. Vertical error bars represent $(+/-)$ one standard error 


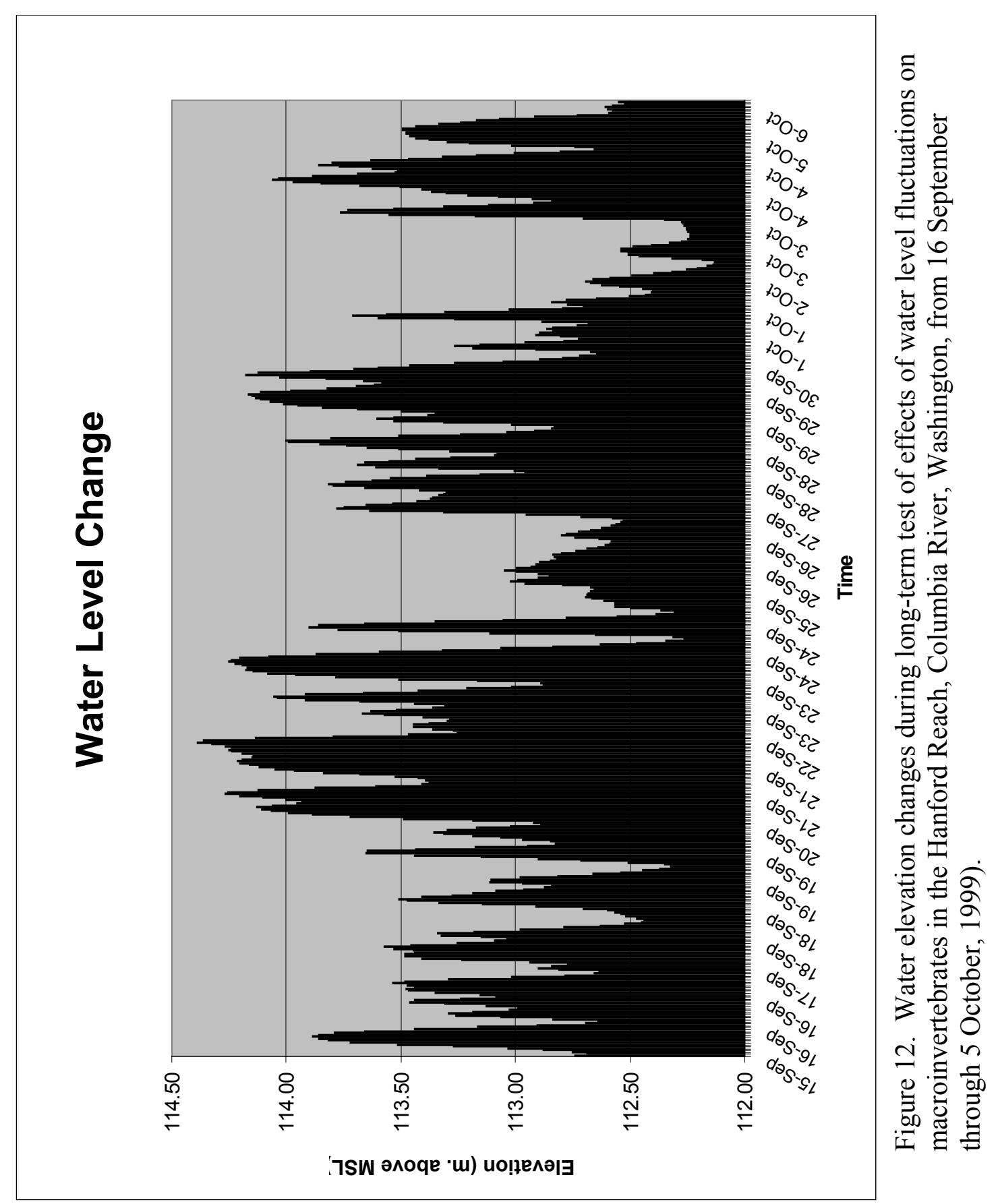




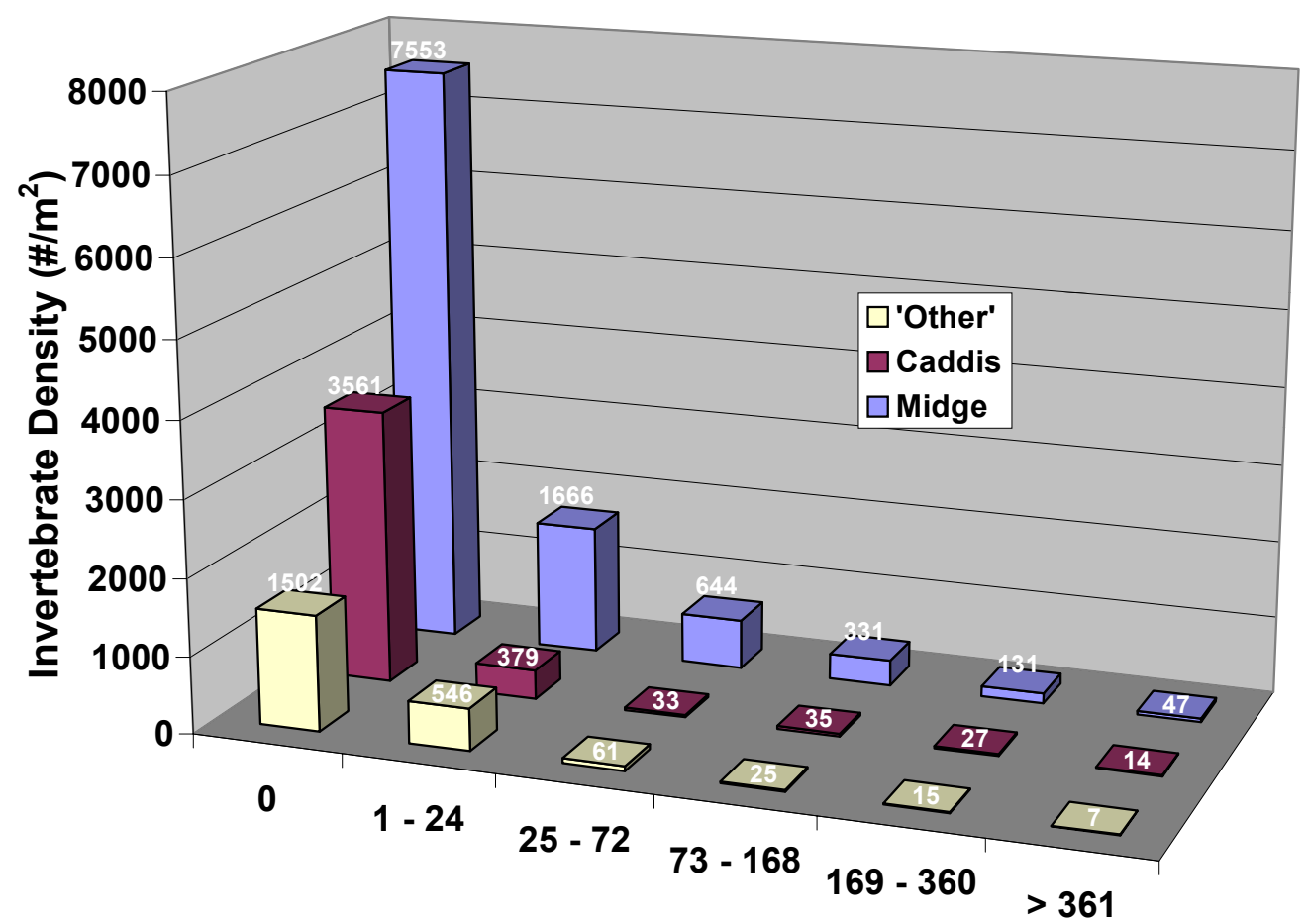

\section{Exposure Treatment (hrs exposure)}

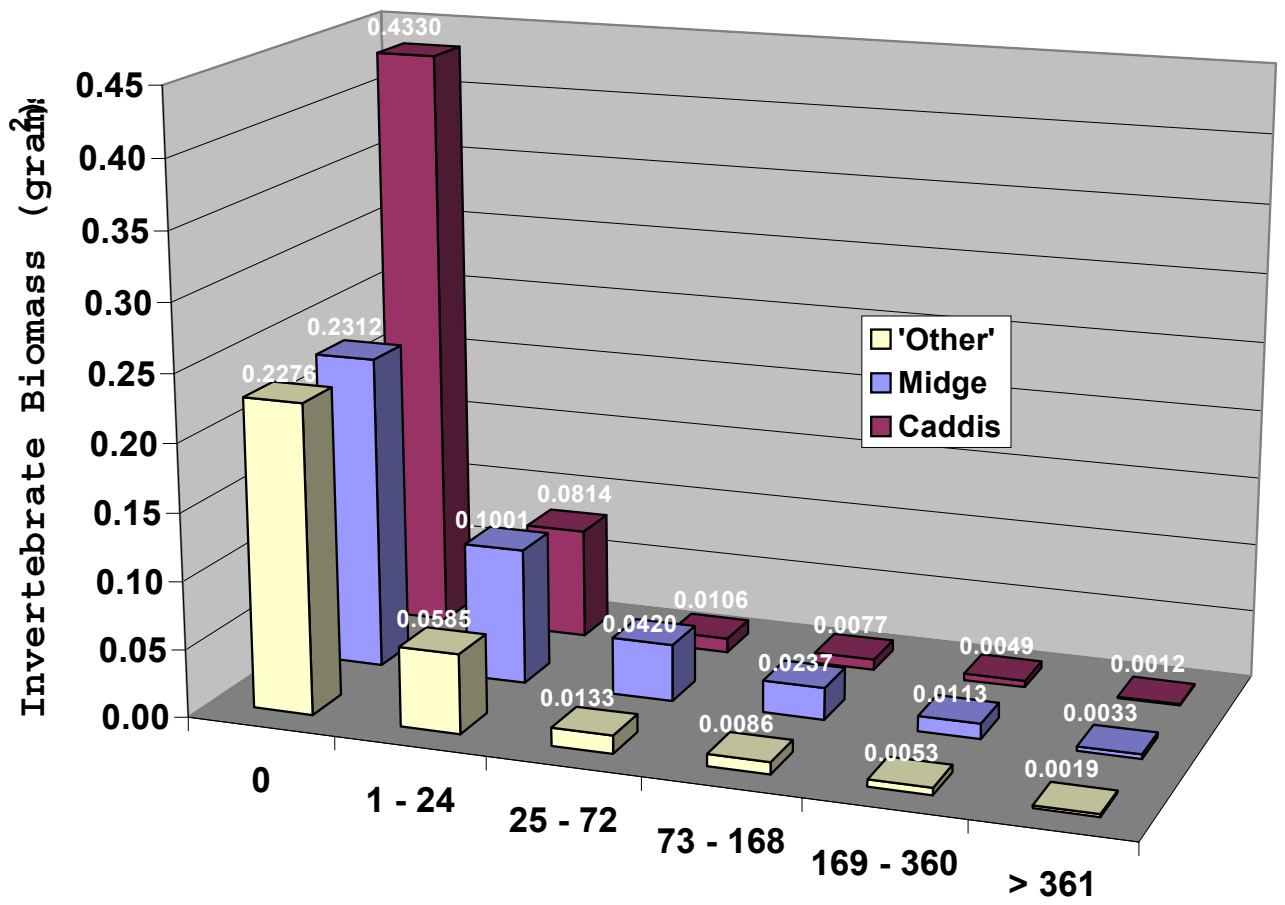

Figure 13. Changes in benthic macroinvertebrate density and biomass with increasing duration of exposure to air during a 21-day test period (Objective 3) at Site 4 (Locke Island) in the Hanford Reach, Columbia River, Washington, 16 September through 5 October, 1999. 

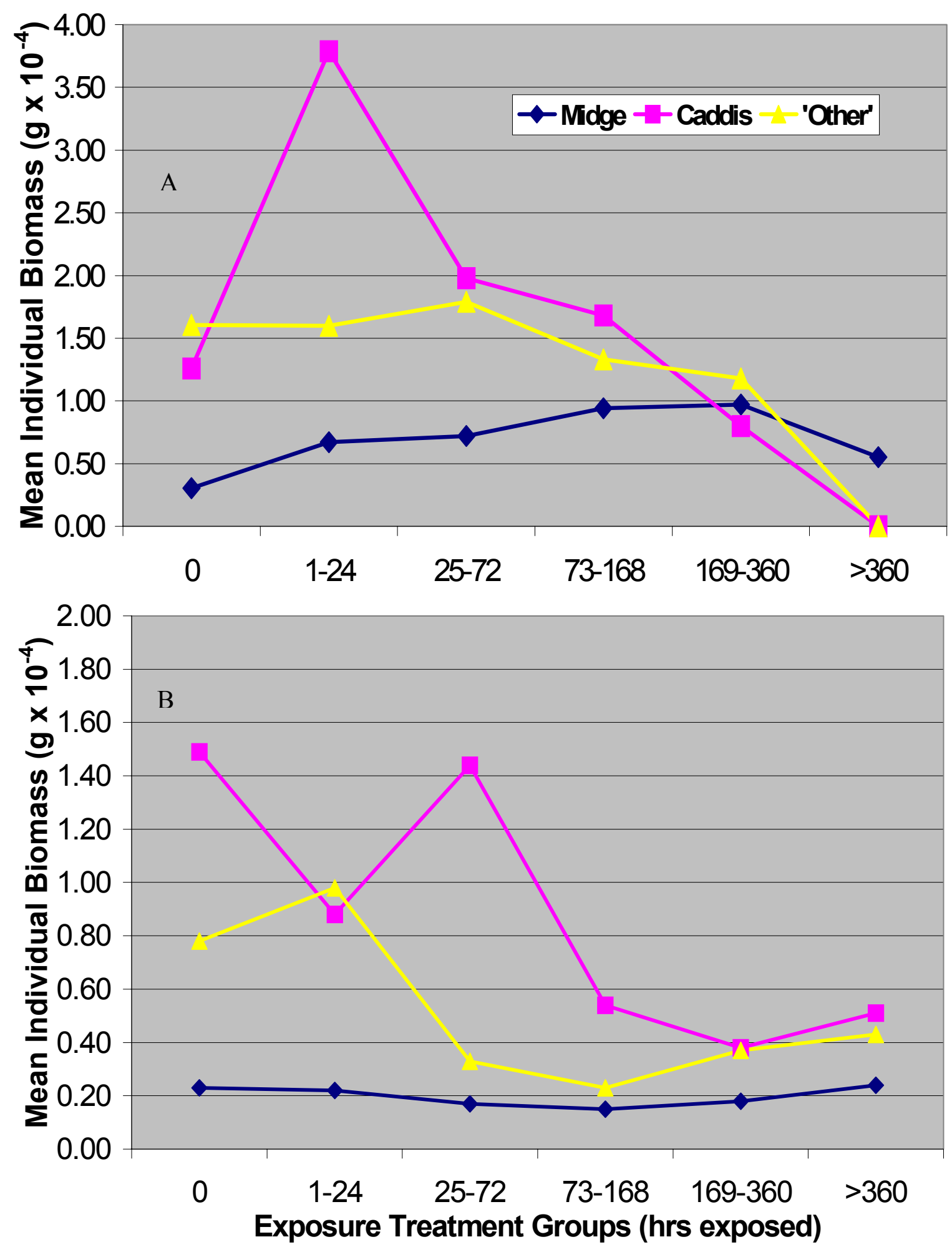

Figure 14. Changes in mean individual biomass of benthic macroinvertebrates found on artificial substrates with increasing duration of exposure to air during a 21-day test period (Objective 3) at Site 4 (A) and Site 5 (B), in the Hanford Reach, Columbia River, Washington, 16 September through 5 October, 1999. 

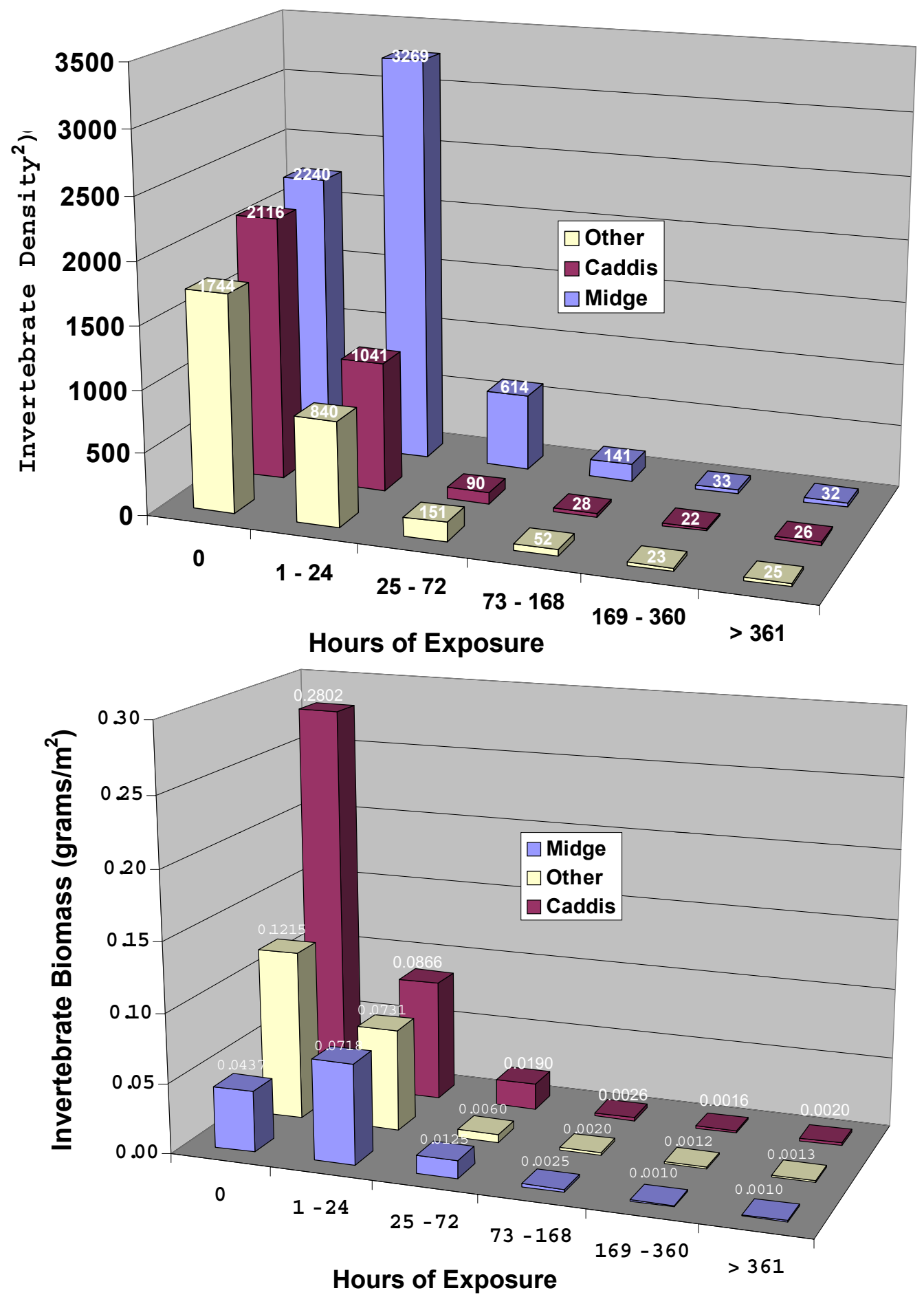

Figure 15. Benthic macroinvertebrate density and biomass with increasing duration of exposure to air during a 21-day test period (Objective 3) at Site 5 (FIsland) in the Hanford Reach, Columbia River, Washington, 16 September through 5 October, 1999. 


\section{Site 4}

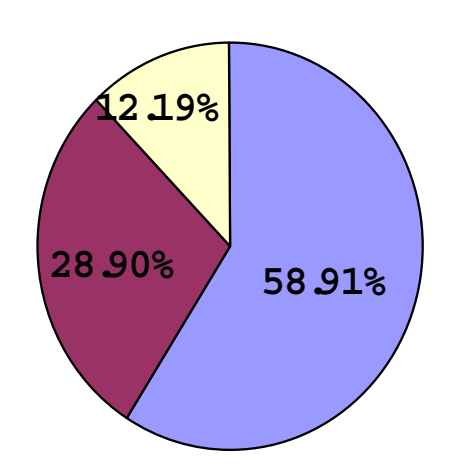

\section{Density}

\section{Biomass}

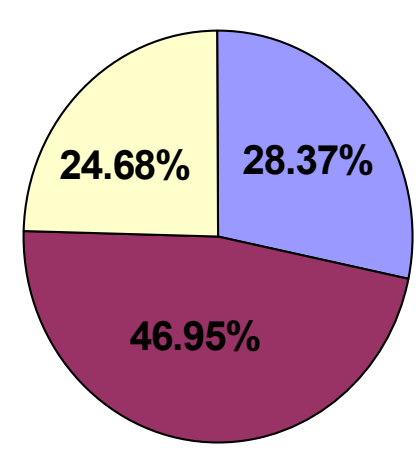

\section{$\underline{\text { Site } 5}$}
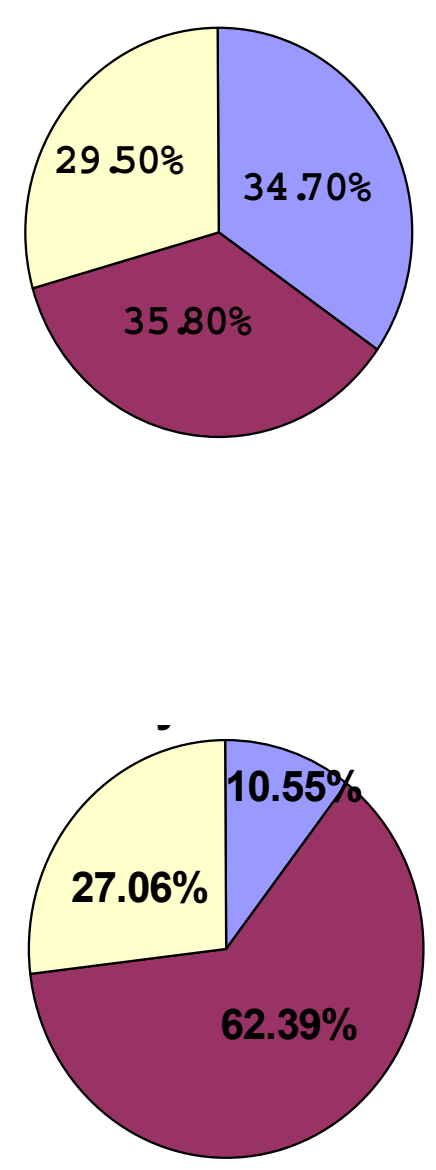

Midge

Caddis

'Other'

Figure 16. Comparison of macroinvertebrate community composition, by density and biomass, on 'control' artificial substrates between Site 4 (Locke Island) and Site 5 (F-Island) long-term test locations in the Hanford Reach, Columbia River, Washington. 16 September through 5 October. 1999. 

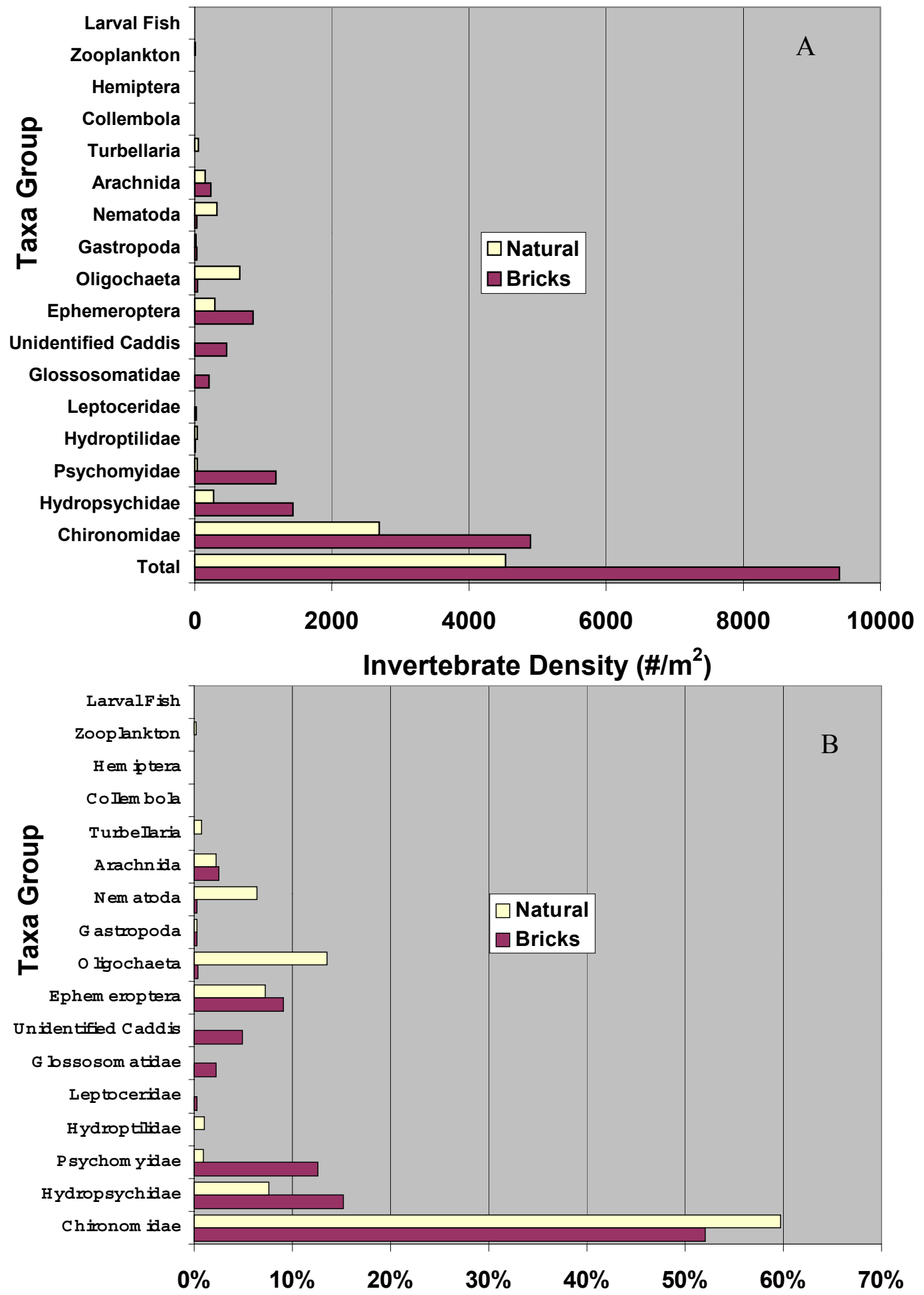

Figure 17. Comparison of benthic macroinvertebrate density (A) and community composition (B) from brick artificial substrates and kick-screen sampled natural substrates Hanford Reach, Columbia River, Washington, October, 1999. 

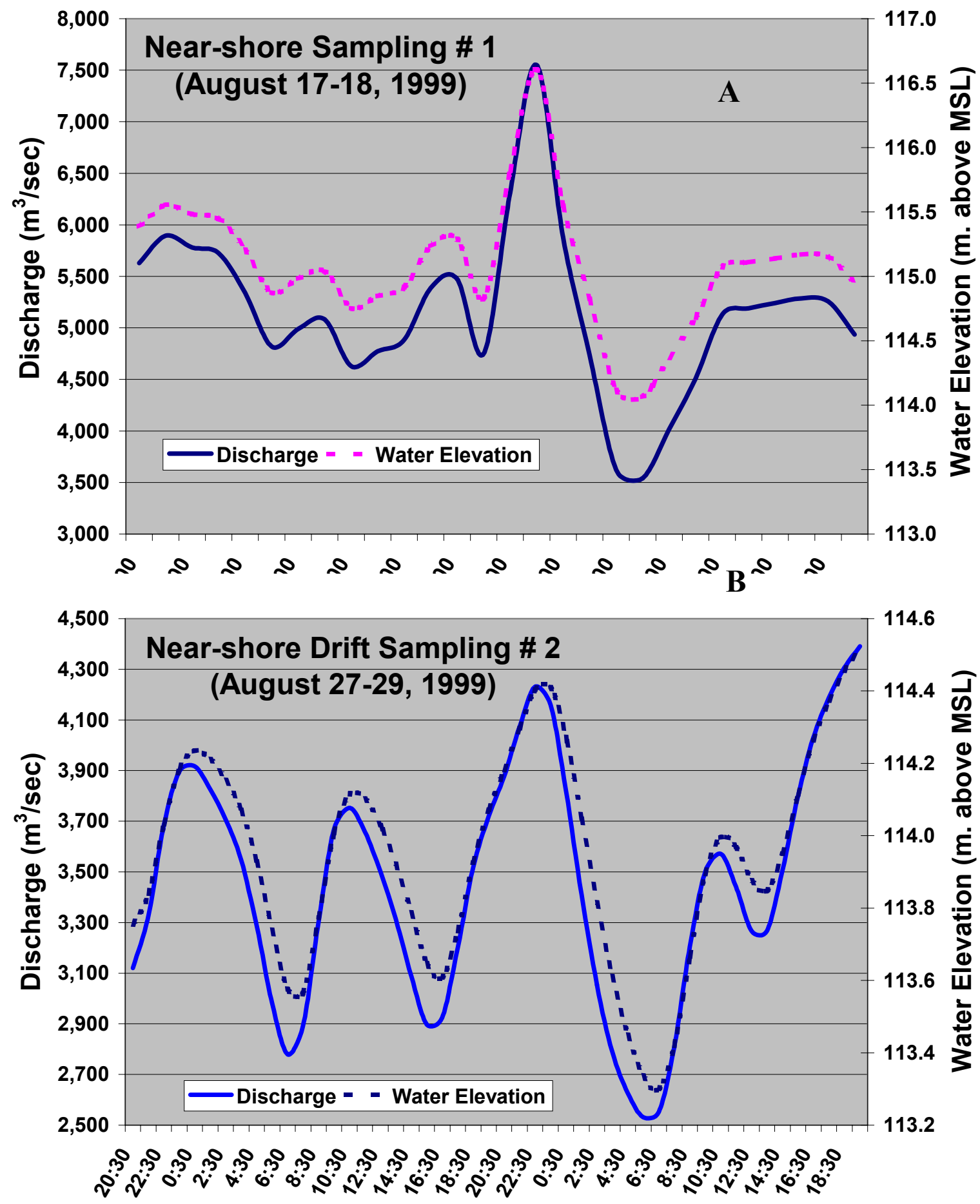

Figure 18. Changes in discharge $\left(\mathrm{m}^{3} / \mathrm{sec}\right)$ and water elevation (meters above mean sea level) during near-shore invertebrate drift sampling, August 17-18 (A) and August 28-29 (B), 1999, at Site 4 (Locke-Island) in the Hanford Reach, Columbia River, Washington. 

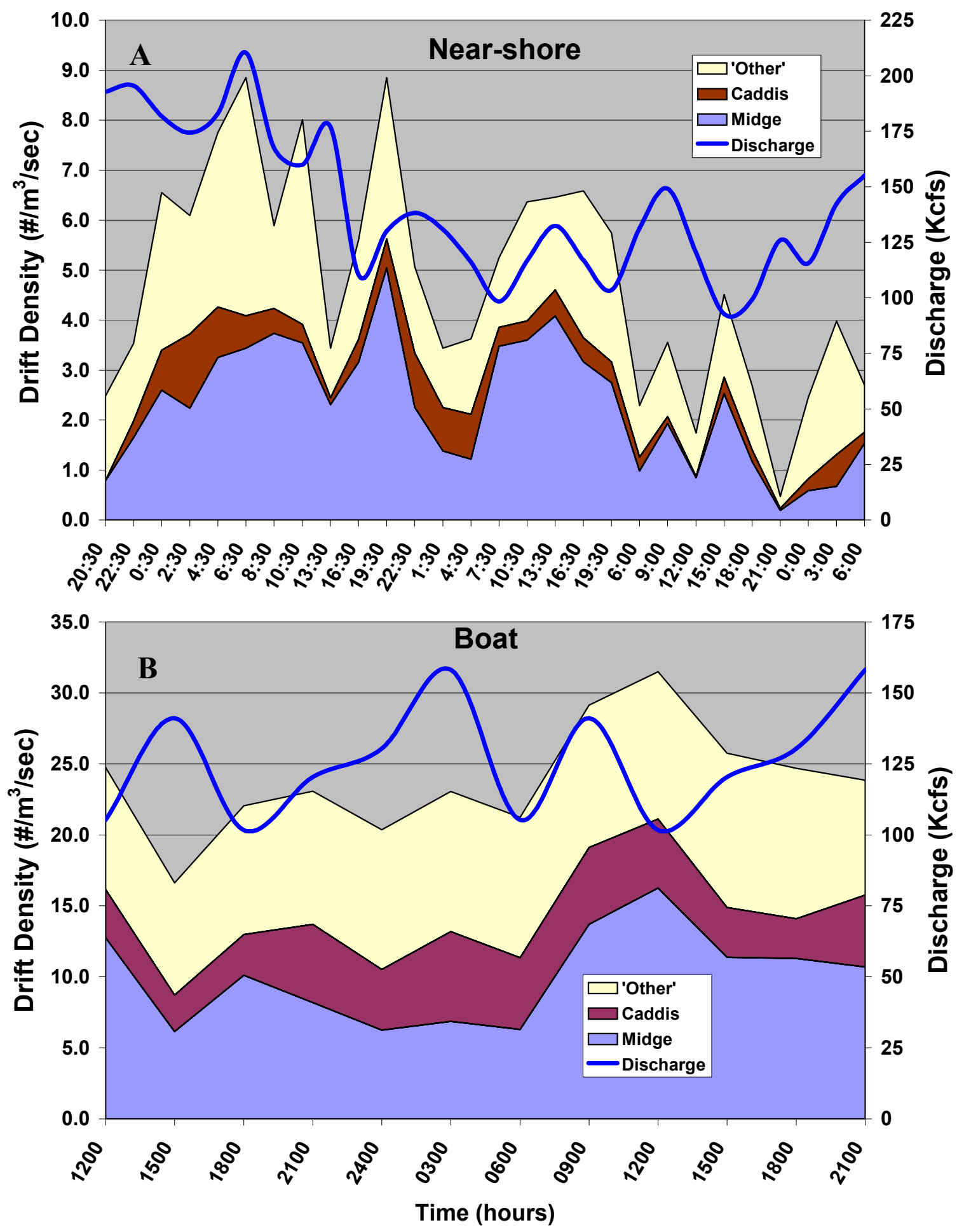

Figure 19. Changes in macroinvertebrate drift density with changes in discharge, collected in near-shore (A) and boat (B) drift sampling at Locke-Island (Site 4) in the Hanford Reach, Columbia River, Washington, August, 1999. 

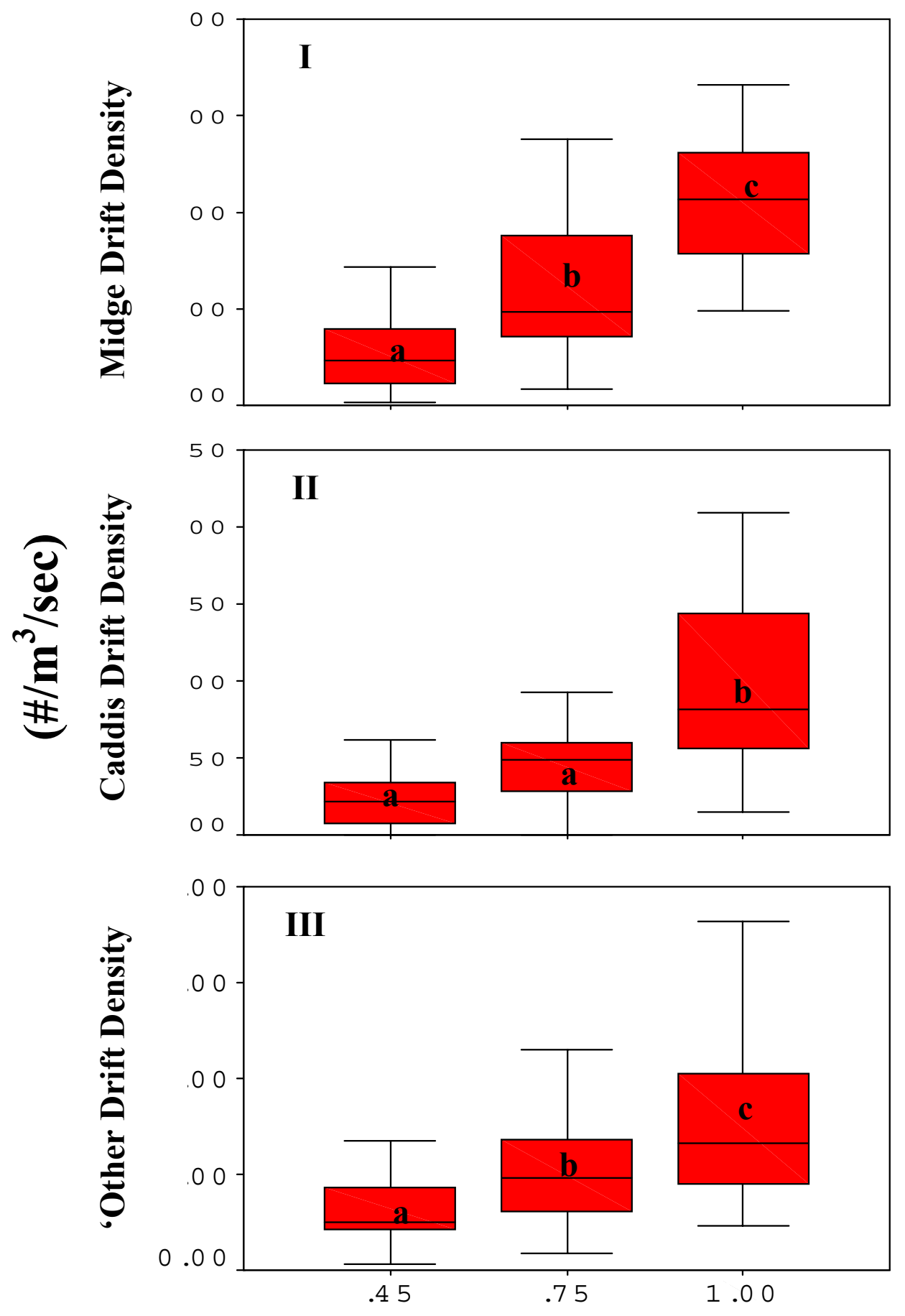

Figure 20. Box plots of mean I) midge, II) caddis, and III) 'other' drift density $\left(\# / \mathrm{m}^{3} / \mathrm{sec}\right)$ by depth $(0.45,0.75$, and $1.0 \mathrm{~m}$.) for the combined near-shore drift sampling at Site 4 (Locke Island) in the Hanford Reach, Columbia River, Washington, August 17-18th and 28-29th, 1999. Plots not sharing the same small letters indicate significant differences $(\mathrm{p}<0.05)$ between depths. 

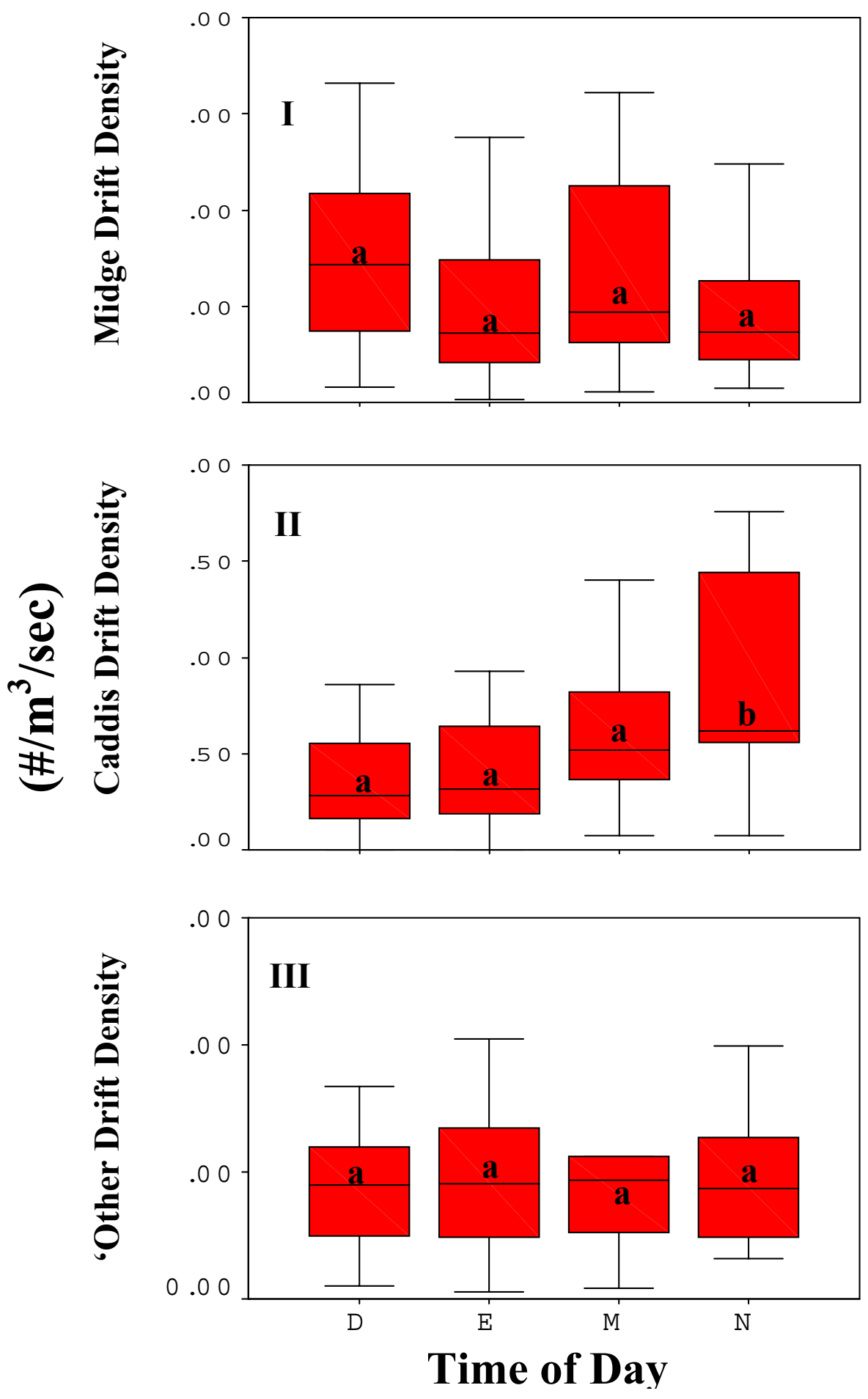

Figure 21. Box plots of mean I) midge, II) caddis, and III) 'other' drift density $\left(\# / \mathrm{m}^{3} / \mathrm{sec}\right)$ by time of day ( $\mathrm{D}=$ day, $\mathrm{E}=$ evening, $\mathrm{N}=$ night, $\mathrm{M}=$ morning) for the combined near-shore drift sampling at Site 4 (Locke Island) in the Hanford Reach, Columbia River, Washington, August 17-18th and 28-29th, 1999. Plots not sharing the same small letters indicate significant differences $(p<0.05)$ between times of day. 


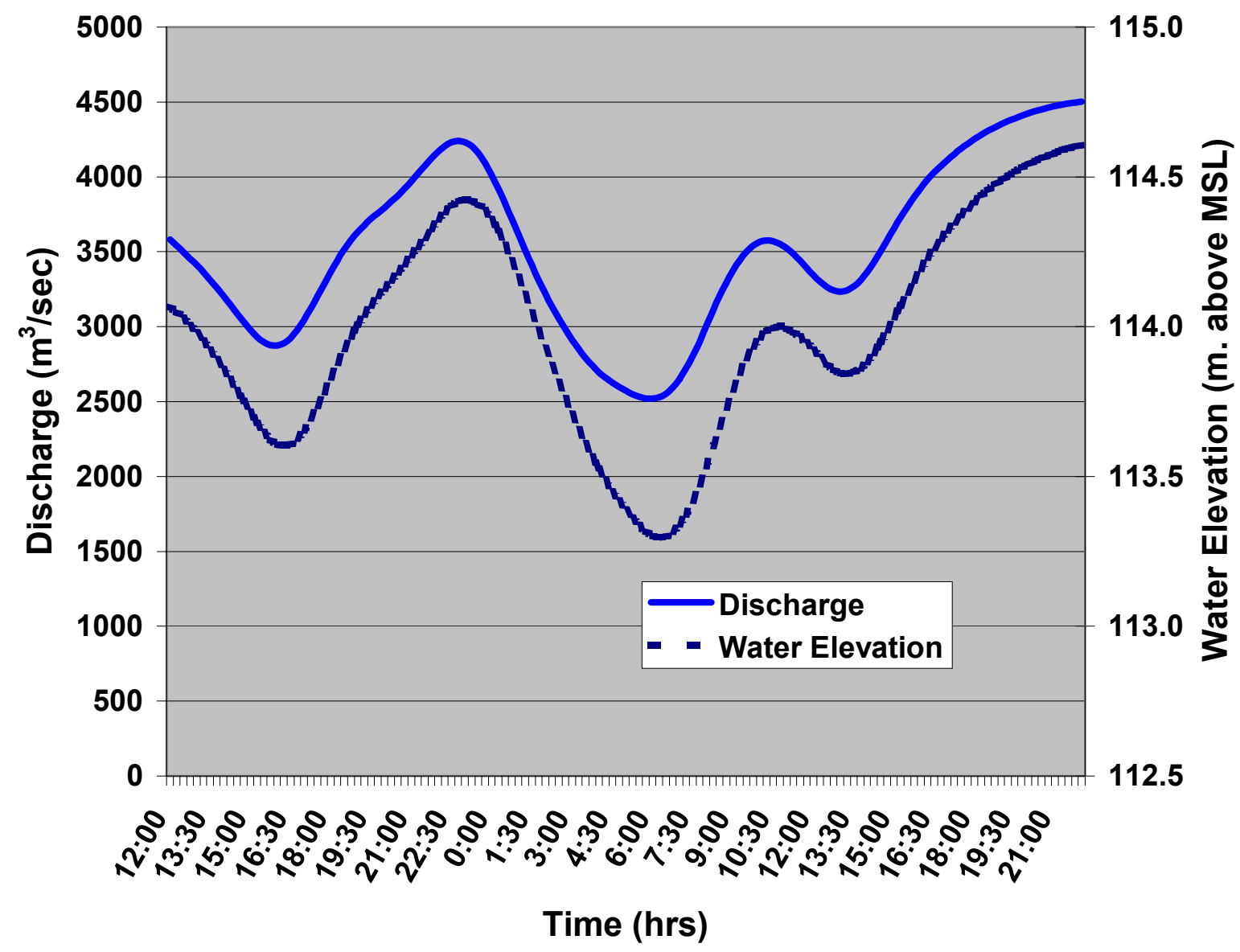

Figure 22. Changes in discharge $\left(\mathrm{m}^{3} / \mathrm{sec}\right)$ and water elevation (meters above mean sea level) during boat invertebrate drift sampling, August 28-29, 1999, at Site 4 (Locke Island) in the Hanford Reach, Columbia River, Washington. 

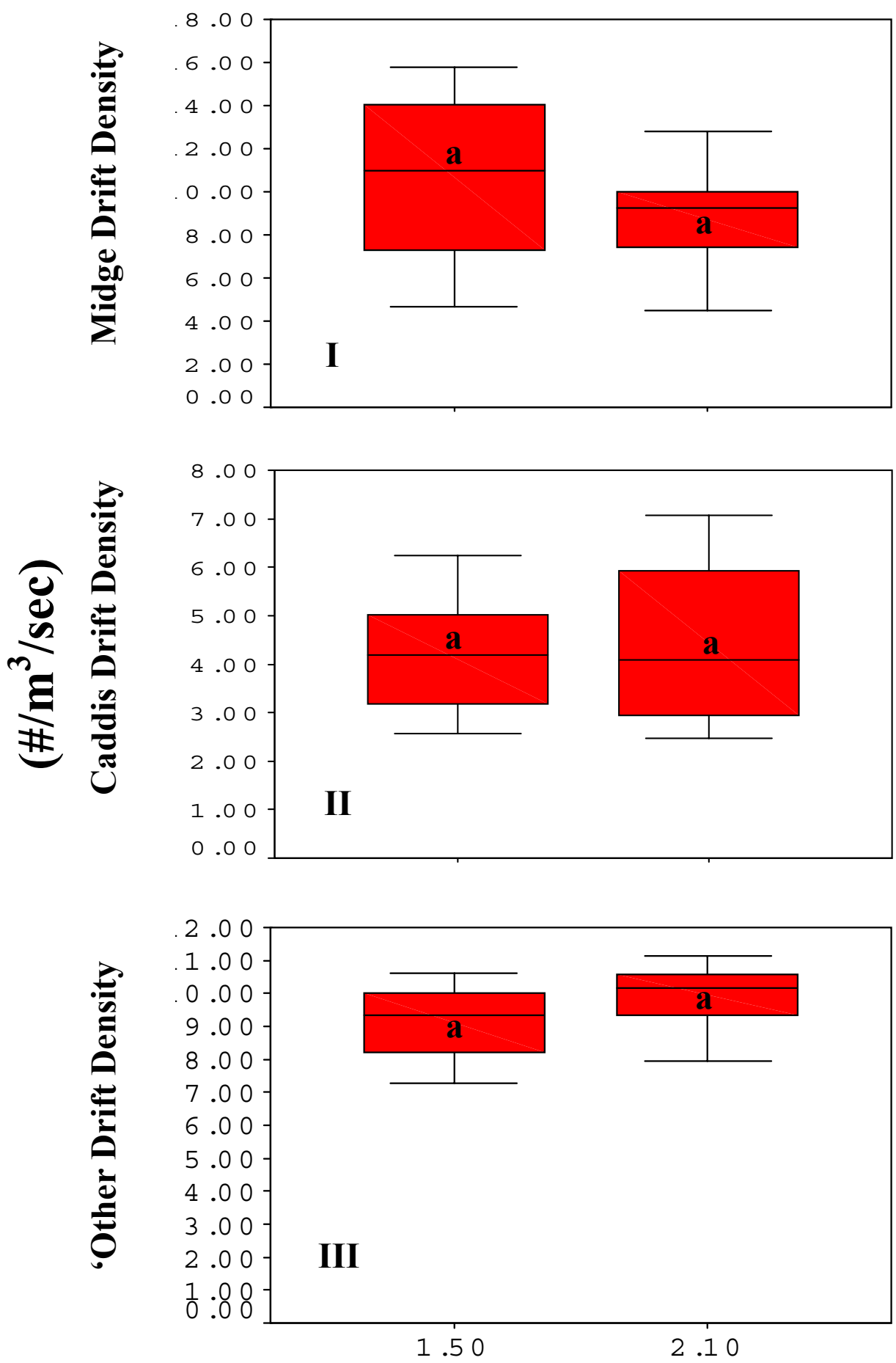

Net Depth (meters)

Figure 23. Box plots of mean I) midge, II) caddis, and III) 'other' drift density by depth $(1.5$ and $2.1 \mathrm{~m}$.) for the boat drift sampling at Site 4 (Locke Island) in the Hanford Reach, Columbia River, Washington, August 28-29th, 1999. Plots not sharing the same small letters indicate significant differences $(p<.05)$ between depths. 

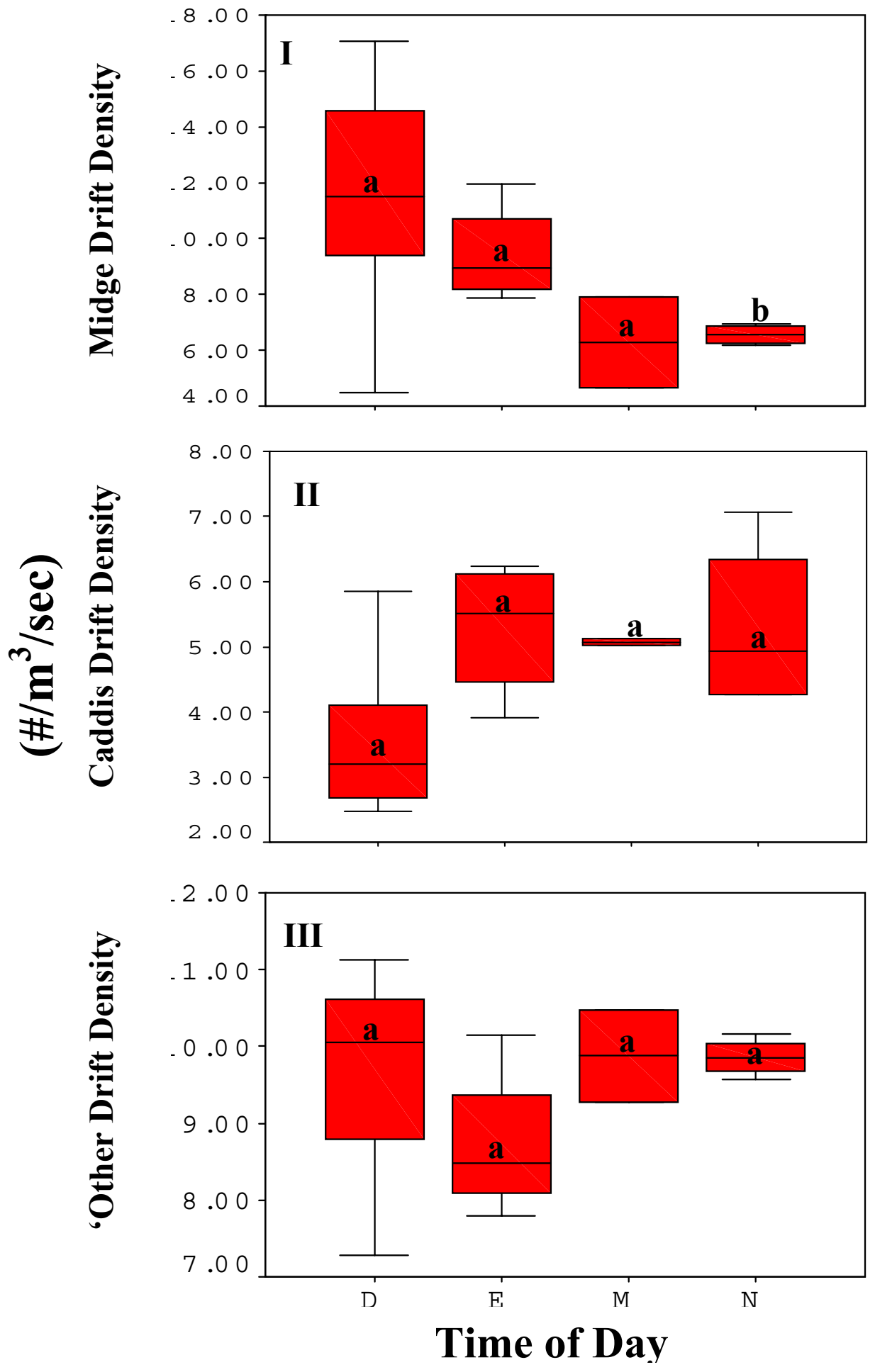

Figure 24. Box plots of mean I) midge, II) caddis, and III) 'other' drift density by time of day ( $\mathrm{D}=$ day, $\mathrm{E}=$ evening, $\mathrm{N}=$ night, $\mathrm{M}=$ morning) for the boat drift sampling at Site 4 (Locke Island) in the Hanford Reach, Columbia River, Washington, August 28-29th, 1999. Plots not sharing the same small letters indicate significant differences $(p<0.05)$ between times of day. 


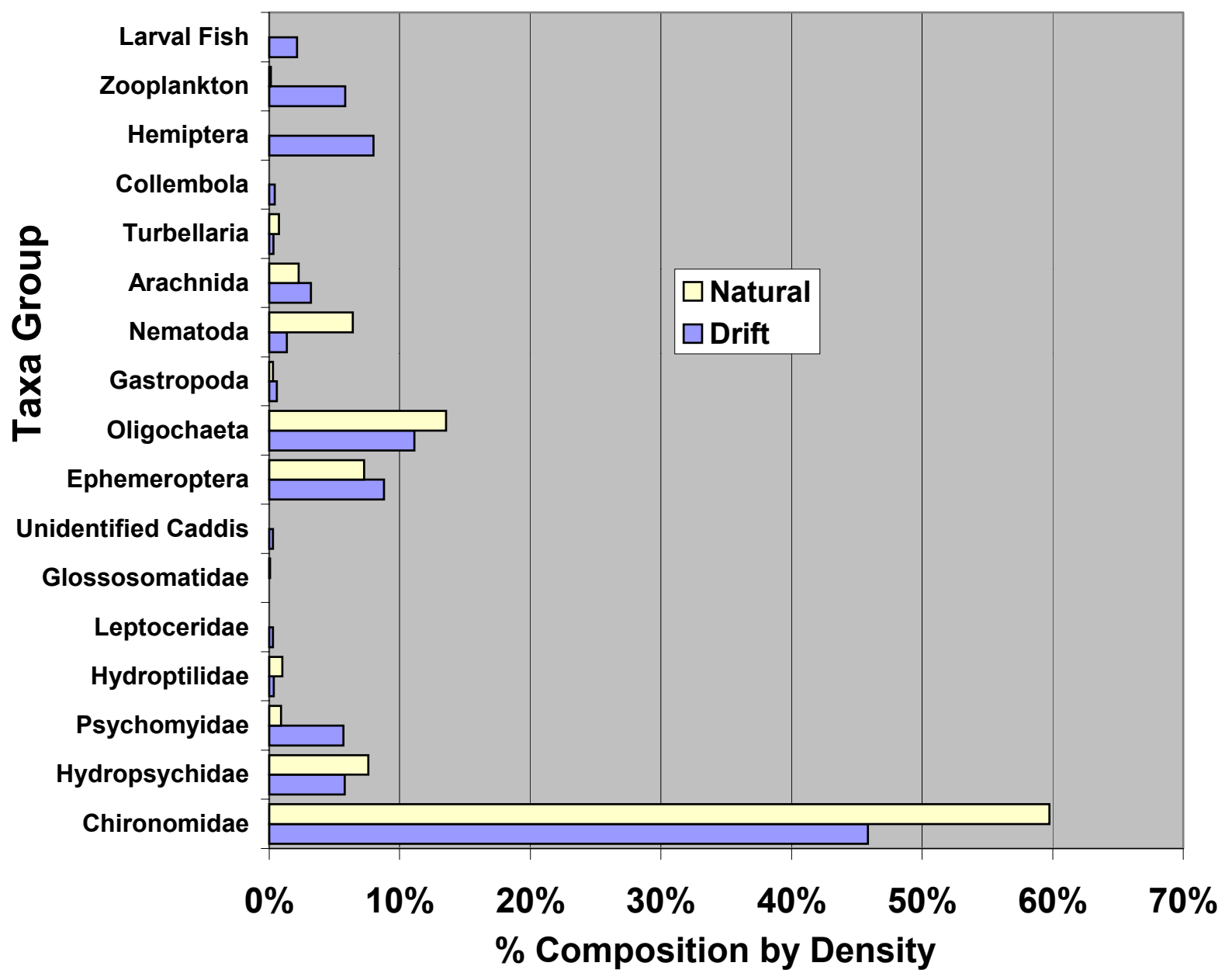

Figure 25. Comparison of macroinvertebrate community composition (by density) between drift and kick-screen natural substrate samples collected from the Hanford Reach, Columbia River, Washington, August 28-29, 1999. 

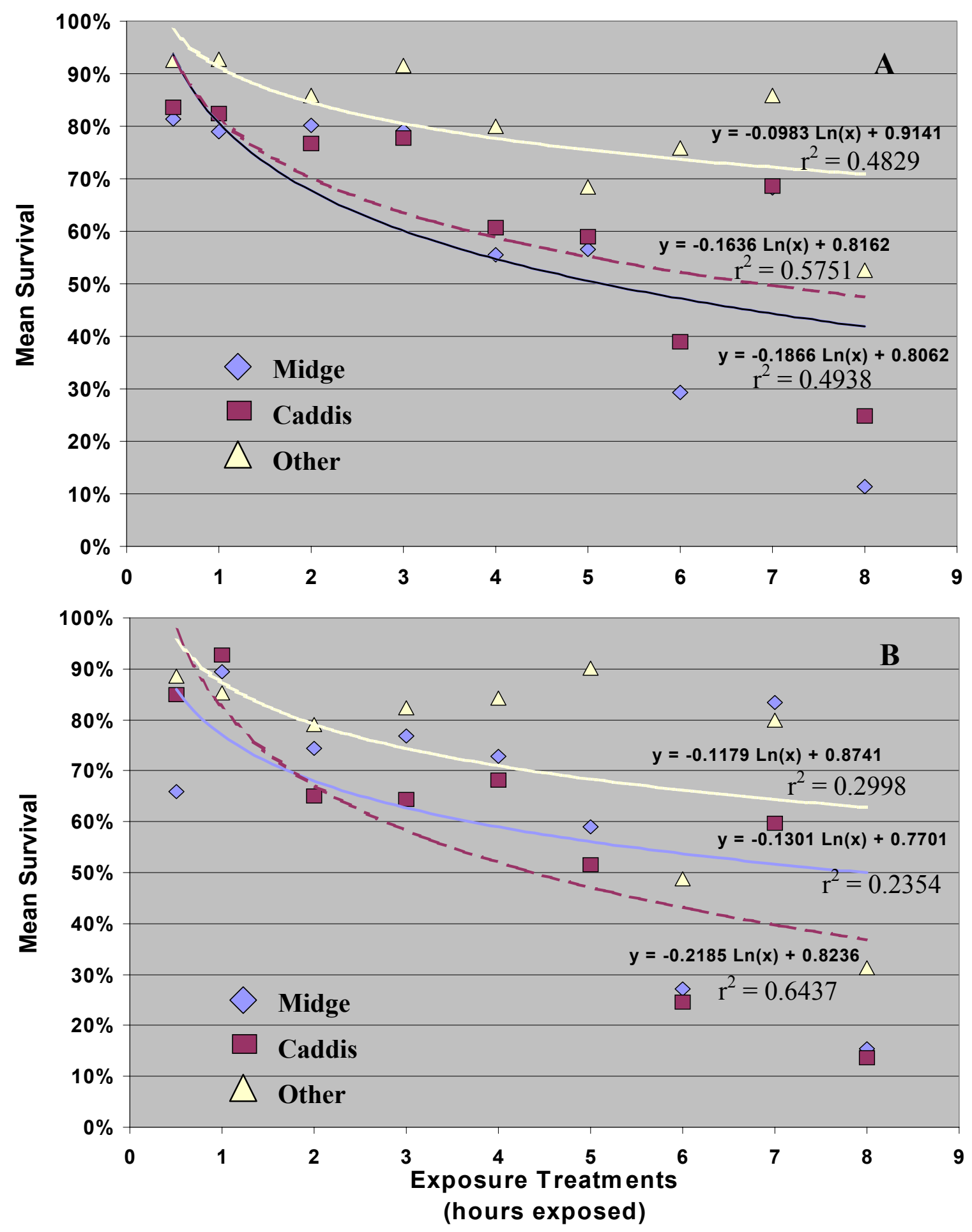

Figure 26. Survival of major invertebrate taxa groups with increasing duration of exposure to air during short-term exposure tests on brick (A) and tile (B) artificial substrates from laboratory-checked samples. Lines represent linear regression relationships, with equation of line and strength of linear relationship $\left(r^{2}\right)$ for each taxa group. 

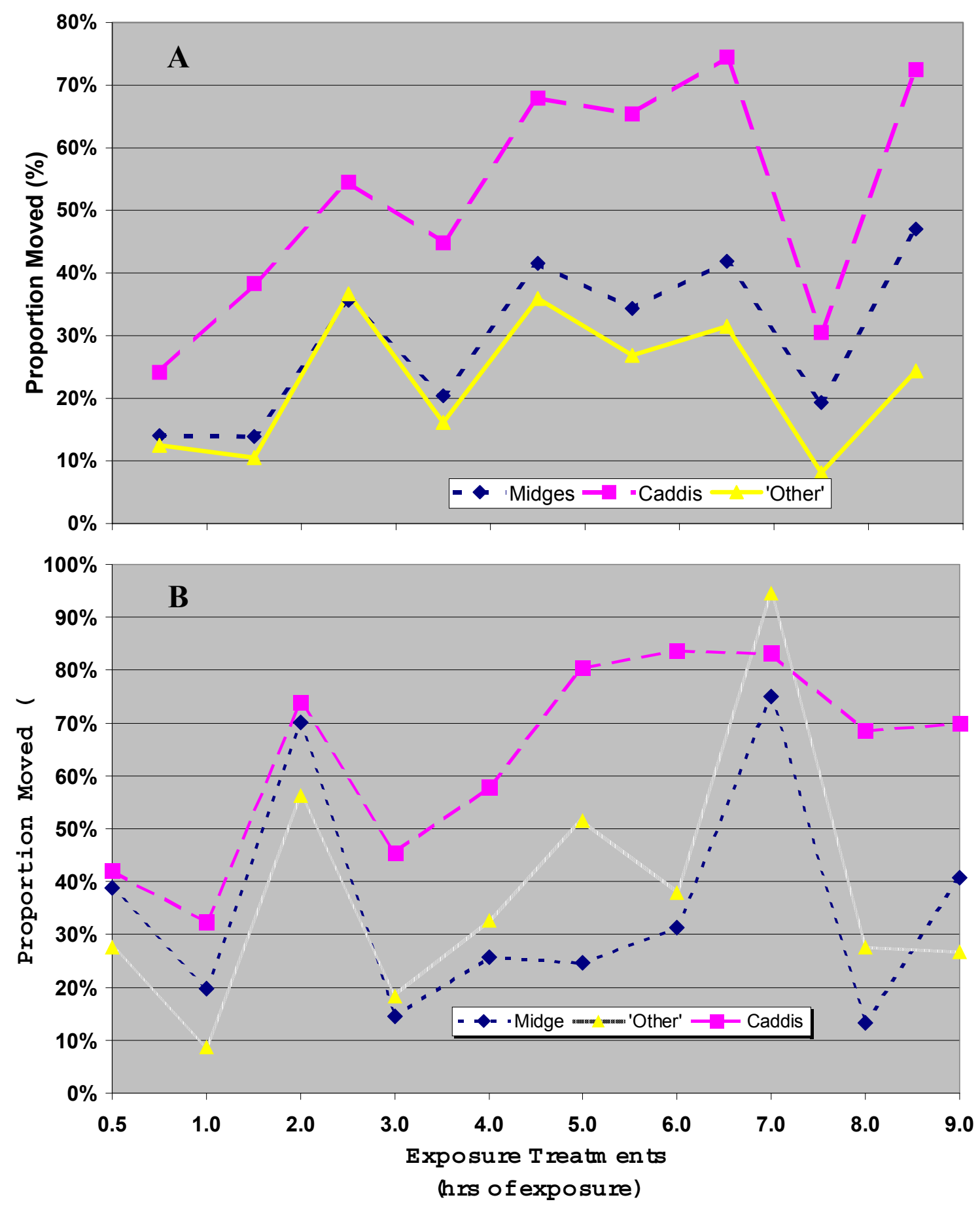

Figure 27. Measures of relative migration of major invertebrate taxa groups (\% mobile) with increasing duration of exposure to air during short-term exposure tests from both laboratory (A) and field-checked (B) samples. 


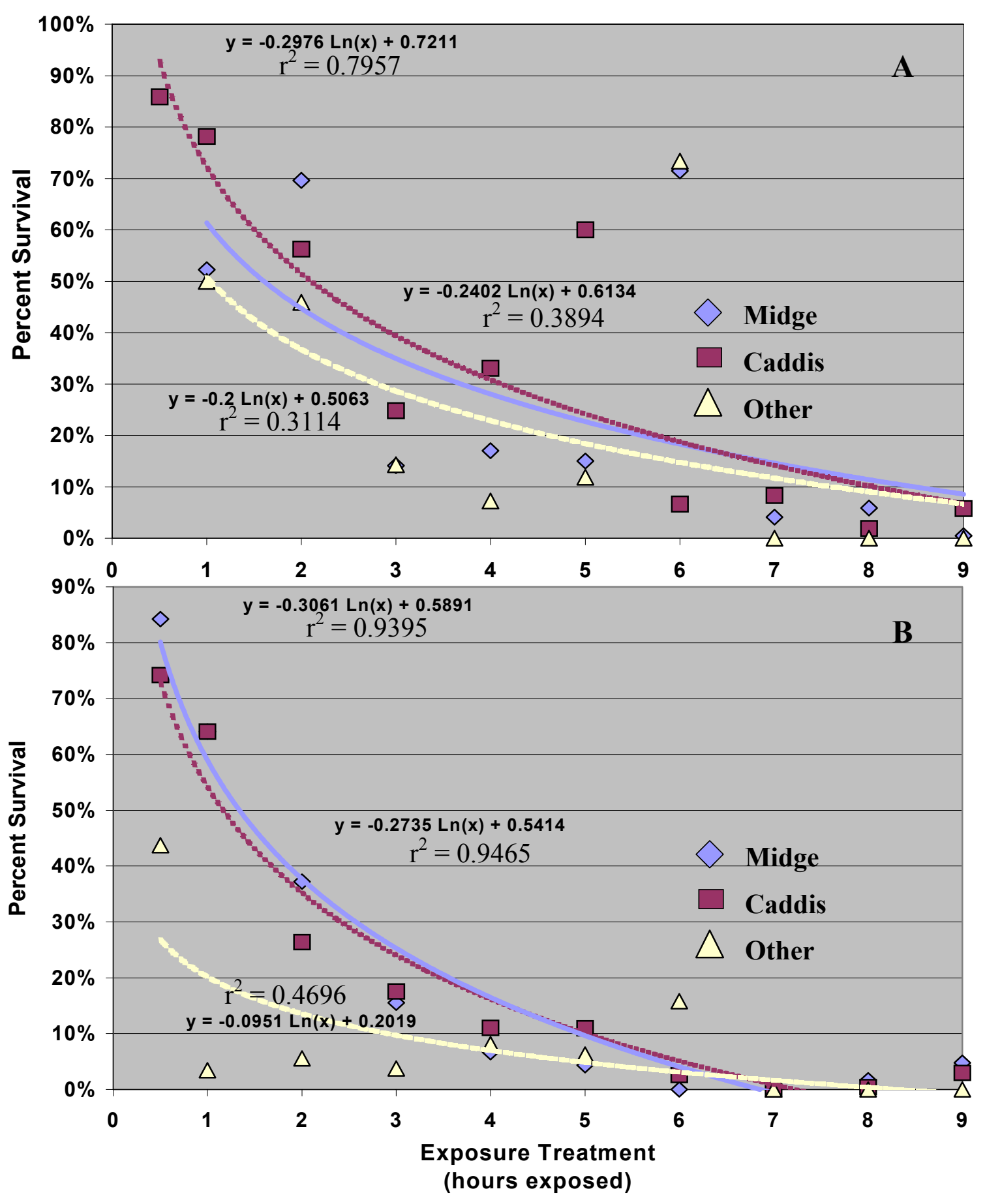

Figure 28. Survival of major invertebrate taxa groups with increasing duration of exposure to air during short-term exposure tests on brick (A) and tile (B) artificial substrates from field-checked samples without replication. Lines represent linear regression relationships, with equation of line and strength of linear relationship $\left(r^{2}\right)$ for each taxa group. 
Stark and Bennett, 1998

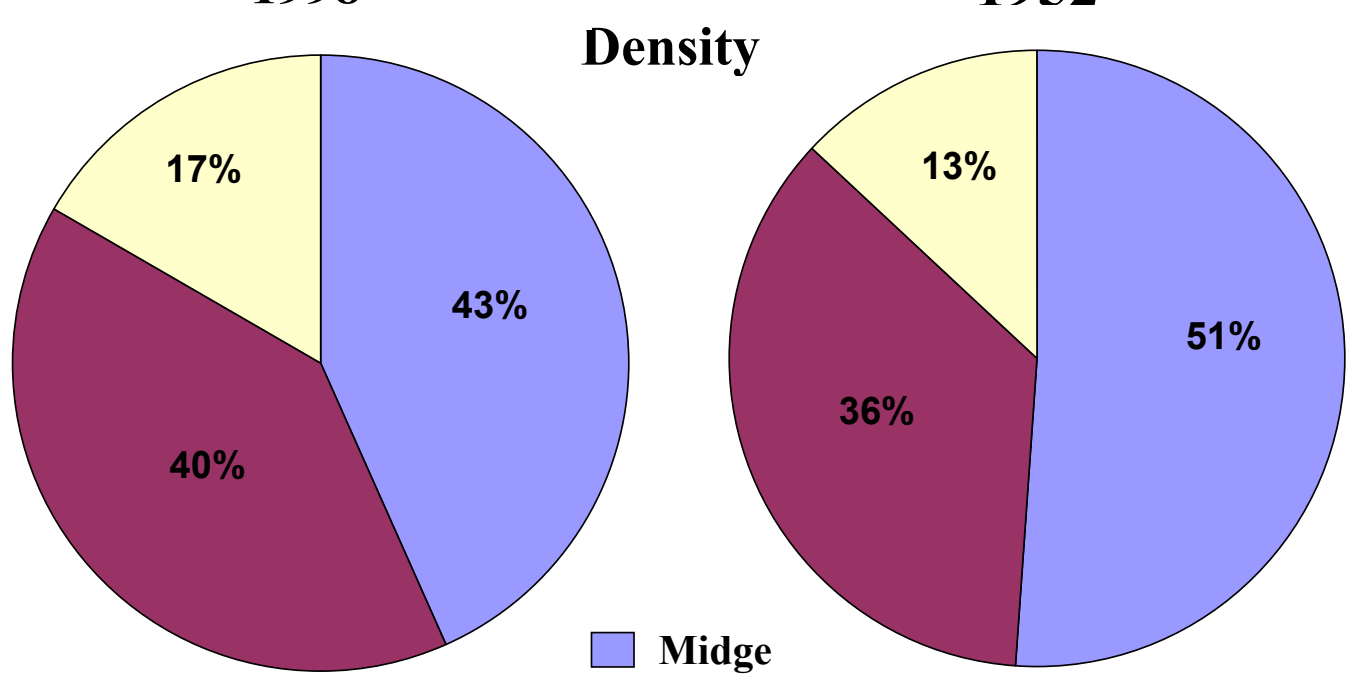

Caddis

$\square$ 'Other'

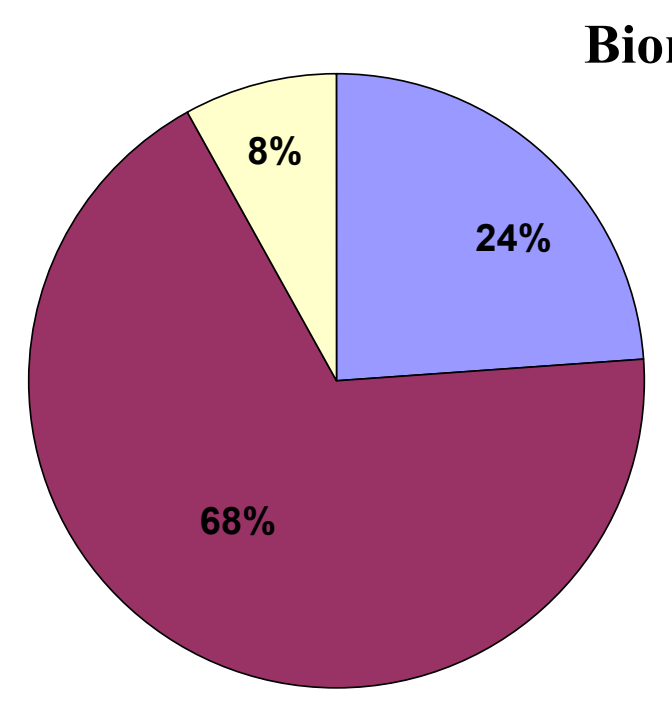

Robeck et al.,

1952 


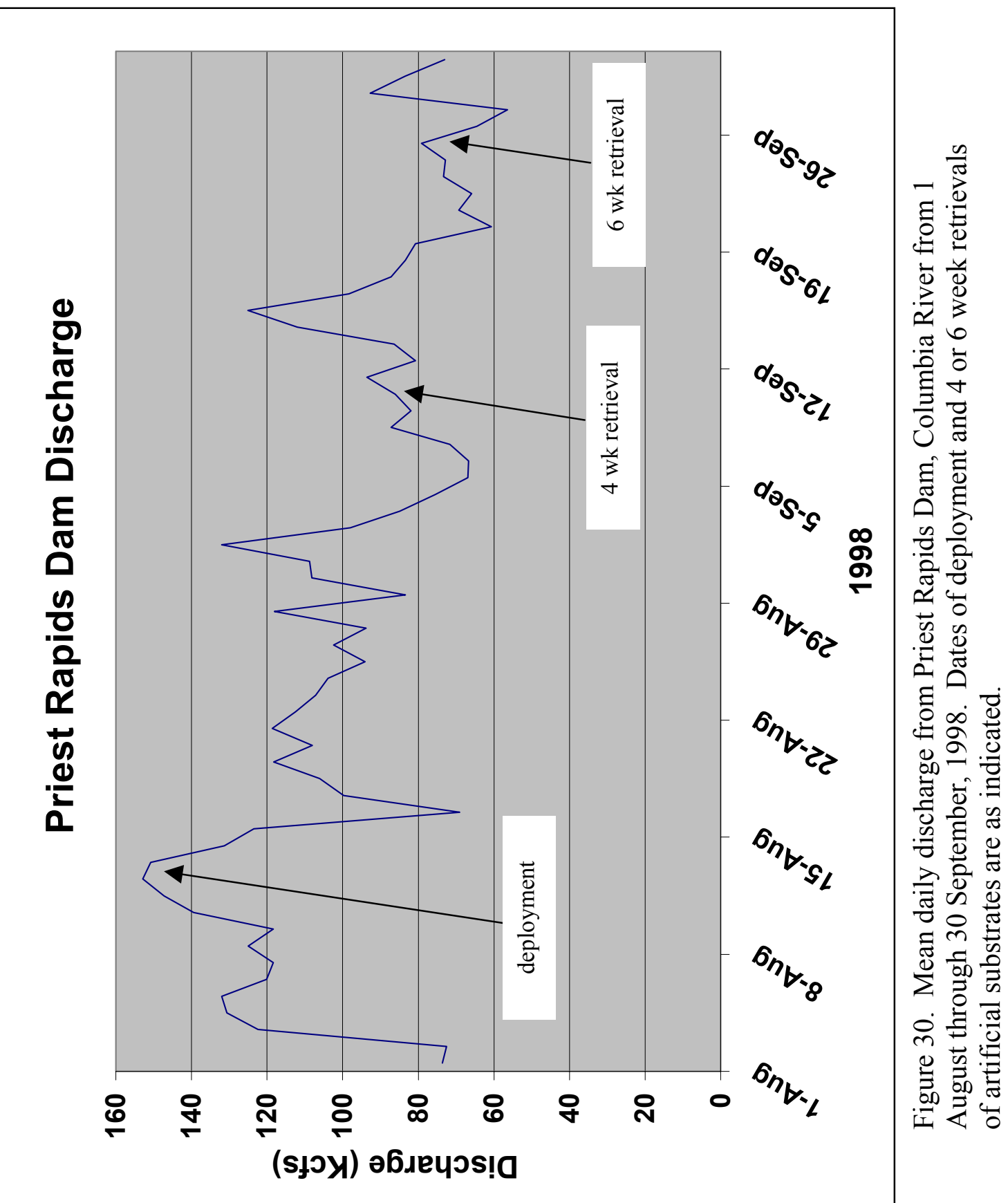



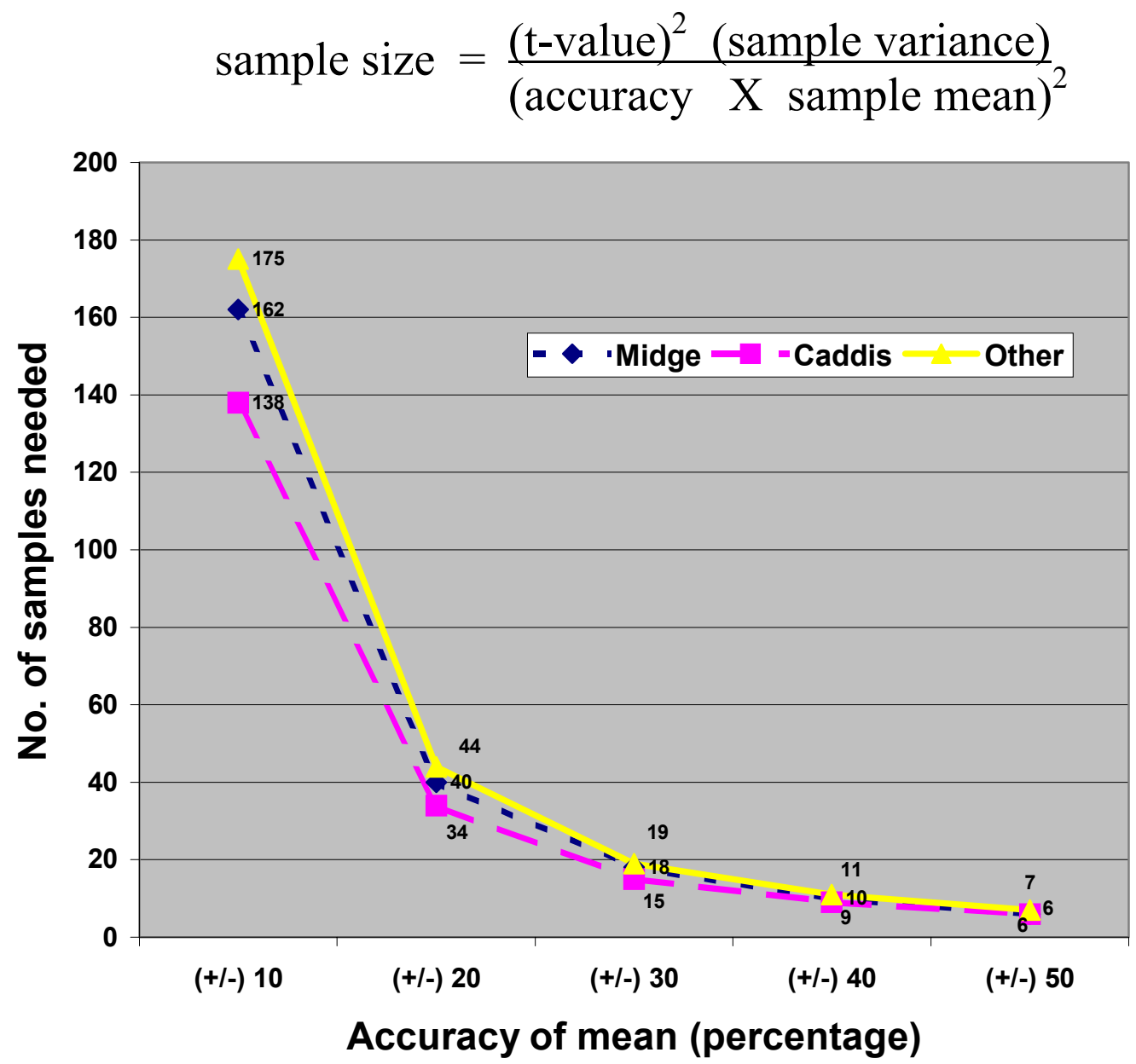

Example: $\quad \mathrm{n}=15, \mathrm{t}$-value $=1.761, \mu=5539$ $\sigma^{2}=16,025,784$, accuracy $=0.10$

$$
\frac{(1761)^{2}(16,025,784)}{(0.10 \times 5539)^{2}}=\begin{aligned}
& 162 \text { samples } \\
& \text { for midges }
\end{aligned}
$$

Figure 31. Benthic macroinvertebrate sample size determination with example calculations using brick artificial substrate samples colonized for 6 weeks at Site 2. 


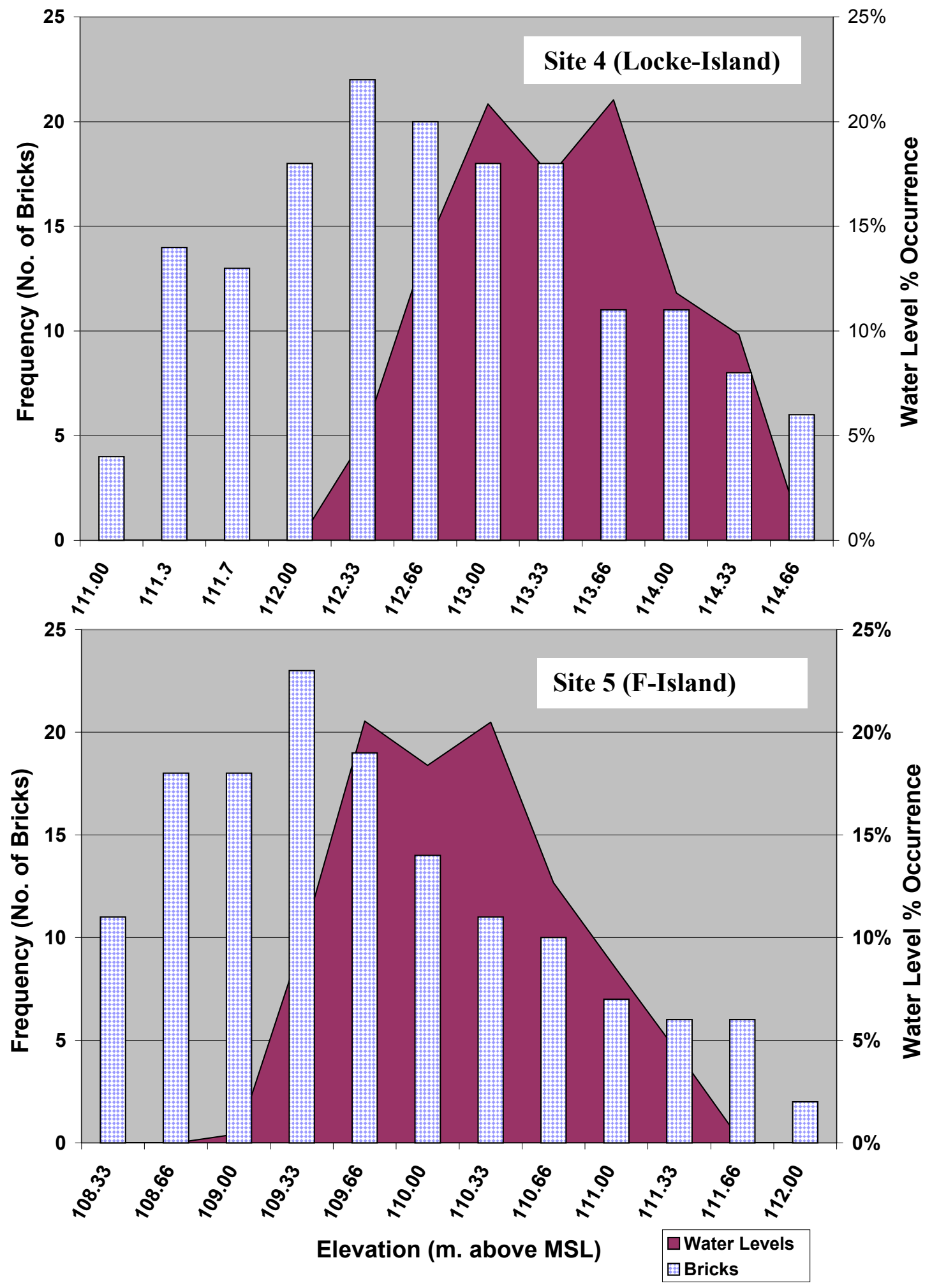

Figure 32. Comparison of brick versus water level elevation distributions at Site 4 (Locke Island) and Site 5 (F-Island) test sites. 
Table1. Mean benthic macroinvertebrate density $\left(\mathrm{No} . / \mathrm{m}^{2}\right)$, standard error (SE), ranges, sample sizes, and coefficient of variation (CV) on artificial substrata in the Hanford Reach, Columbia River. Site 1 was at river mile 368.0, site 2 at RM 370.5, and site 3 at RM 379.0. Colonization periods (4wk or $6 \mathrm{wk})$ and sites $(1,2,3)$ show the combined density of both bricks and baskets.

\begin{tabular}{ccccccc}
\hline \hline Mean & $\left(\mathrm{No} . / \mathrm{m}^{2}\right)$ & (+/-) SE & Min & Max & (n) & CV \\
\hline Brick & 21388 & 1672 & 589 & 60936 & 75 & 83.76 \\
Basket & 33854 & 3319 & 500 & 134652 & 73 & 67.70 \\
\hline 4 wk & 30457 & 3049 & 500 & 134652 & 79 & 88.98 \\
6 wk & 24193 & 2087 & 917 & 78233 & 69 & 71.66 \\
\hline Site 1 & 20836 & 1806 & 5180 & 53205 & 38 & 53.43 \\
Site 2 & 41906 & 3550 & 917 & 134652 & 60 & 65.62 \\
Site 3 & 15387 & 1862 & 500 & 54132 & 50 & 85.57 \\
\hline
\end{tabular}

Table 2. Mean benthic macroinvertebrate dry weight biomass $\left(\mathrm{g} / \mathrm{m}^{2}\right)$, standard error (SE), ranges, sample sizes, and coefficient of variation (CV) on artificial substrata in the Hanford Reach, Columbia River. Site 1 was at river mile 368.0, site 2 at RM 370.5, and site 3 at RM 379.0. Colonization periods (4wk or $6 \mathrm{wk}$ ) and sites $(1,2,3)$ show the combined density of both bricks and baskets.

\begin{tabular}{ccccccc}
\hline \hline Mean & $\left(\mathrm{g} . / \mathrm{m}^{2}\right)$ & (+/-) SE & Min & Max & (n) & CV \\
\hline Brick & 1.74 & 0.16 & 0.06 & 6.81 & 75 & 92.38 \\
Basket & 2.78 & 0.30 & 0.03 & 11.76 & 73 & 81.72 \\
4 wk & 2.02 & 0.22 & 0.03 & 9.42 & 79 & 97.73 \\
6 wk & 2.52 & 0.27 & 0.11 & 11.76 & 69 & 90.08 \\
Site 1 & 1.39 & 0.12 & 0.38 & 3.62 & 38 & 52.27 \\
Site 2 & 3.59 & 0.32 & 0.18 & 11.76 & 60 & 69.93 \\
Site 3 & 1.31 & 0.19 & 0.03 & 7.29 & 50 & 105.27 \\
\hline
\end{tabular}


Table 3. Water level changes at Locke Island (Site 4) and F Island (Site 5) during the 21day long-term test period in the Hanford Reach, Columbia River, Washington. Water elevations are expressed in meters above mean sea level.

\begin{tabular}{lrr}
\hline \hline Water level elevation & Locke Island & F-Island \\
\hline Mean & 113.23 & 110.38 \\
Standard deviation & 0.55 & 0.55 \\
Maximum & 111.46 & 111.60 \\
Minimum & 109.17 & 109.32 \\
Max water level change & 2.29 & 2.28 \\
Max hourly change & 0.47 & 0.39 \\
Mean hourly change & 0.11 & 0.10 \\
\hline
\end{tabular}

Table 4. Summary of long-term objective exposure treatment groups, hours of exposure, percent of time exposed, and sample sizes at Locke and F-Island sites, Hanford Reach, Columbia River, Washington.

\begin{tabular}{cllccc}
\hline \hline \multirow{2}{*}{$\begin{array}{c}\text { Exposure } \\
\text { Treatment }\end{array}$} & \multicolumn{1}{c}{$\begin{array}{c}\text { Hours } \\
\text { Exposed }\end{array}$} & \multirow{2}{*}{$\begin{array}{c}\text { Percent (\%) of } \\
\text { Time Exposed }\end{array}$} & \multicolumn{2}{c}{ Sample Size (n) \# of Bricks } \\
\cline { 4 - 5 } & 0 & 0 & Locke Is. & F-Island \\
\hline A & 0 & $0.20-4.82$ & 37 & 46 \\
B & $1-24$ & $4.83-14.46$ & 12 & 12 \\
C & $25-72$ & $14.47-33.73$ & 18 & 15 \\
D & $73-168$ & $33.94-72.29$ & 17 & 18 \\
E & $169-360$ & $>72.29$ & 35 & 26 \\
F & $>361$ & 100 & 31 & 18 \\
G & 498 & Total: & 18 & 10 \\
\hline
\end{tabular}


Table 5. Checklist of mean density (No. $/ \mathrm{m}^{2}$ ) and percent composition (\%) of macroinvertebrate taxa by density along a long-term exposure test transect. Mean values of total density and biomass, percent reduction and percent midge by density and biomass, total taxa, total individuals, and taxonomic diversity for both sites combined.

\begin{tabular}{|c|c|c|c|c|c|c|}
\hline & \multicolumn{6}{|c|}{ Zone $^{\mathrm{a}}$} \\
\hline & $\mathbf{A}$ & B & $\mathbf{C}$ & D & $\mathbf{E}$ & $\mathbf{F}$ \\
\hline \multicolumn{7}{|l|}{ Platyhelminthes } \\
\hline \multirow[t]{2}{*}{ Turbellaria } & 3 & 1 & 0 & 0 & 0 & 0 \\
\hline & $(0.04)$ & $(0.03)$ & $(0.00)$ & $(0.00)$ & $(0.00)$ & $(0.00)$ \\
\hline \multirow[t]{2}{*}{ Nematoda } & 29 & 16 & 2 & 2 & 1 & 3 \\
\hline & $(0.31)$ & $(0.42)$ & $(0.25)$ & $(0.63)$ & $(0.59)$ & (3.94) \\
\hline \multicolumn{7}{|l|}{ Annelida } \\
\hline \multirow[t]{2}{*}{ Oligochaeta } & 38 & 122 & 35 & 3 & 2 & 0 \\
\hline & $(0.40)$ & $(3.20)$ & (4.37) & $(1.08)$ & $(1.84)$ & $(0.00)$ \\
\hline \multicolumn{7}{|l|}{ Arthropoda } \\
\hline \multicolumn{7}{|l|}{ Crustacea } \\
\hline \multirow[t]{2}{*}{ Amphipoda } & 0 & 0 & 0 & 0 & 0.30 & 0 \\
\hline & $(0.00)$ & $(0.00)$ & $(0.00)$ & $(0.00)$ & $(0.24)$ & $(0.00)$ \\
\hline \multicolumn{7}{|l|}{ Insecta } \\
\hline \multirow[t]{2}{*}{ Ephemeroptera } & 852 & 274 & 31 & 19 & 9 & 8 \\
\hline & $(4.95)$ & $(1.60)$ & $(0.56)$ & $(1.88)$ & $(3.68)$ & $(1.48)$ \\
\hline \multicolumn{7}{|l|}{ Trichoptera } \\
\hline \multirow[t]{2}{*}{ Hydropsychidae } & 1430 & 218 & 29 & 16 & 14 & 11 \\
\hline & $(15.21)$ & $(5.74)$ & $(3.62)$ & (5.39) & (11.15) & $(15.10)$ \\
\hline \multirow[t]{2}{*}{ Psychomyiidae } & 1184 & 399 & 25 & 11 & 9 & 7 \\
\hline & $(12.59)$ & $(10.51)$ & (3.11) & $(3.69)$ & $(6.85)$ & $(9.80)$ \\
\hline \multirow[t]{2}{*}{ Glossosomatidae } & 206 & 2 & 2 & 0 & 0.19 & 0 \\
\hline & $(2.190$ & $(0.05)$ & $(0.25)$ & $(0.00)$ & $(0.15)$ & $(0.00)$ \\
\hline \multirow[t]{2}{*}{ Hydroptilidae } & 8 & 9 & 2 & 1 & 0.19 & 0 \\
\hline & $(0.09)$ & $(0.24)$ & $(0.31)$ & $(0.36)$ & $(0.15)$ & $(0.00)$ \\
\hline \multirow[t]{2}{*}{ Leptoceridae } & 24 & 2 & 2 & 2 & 1 & 1 \\
\hline & $(0.26)$ & $(0.04)$ & $(0.21)$ & $(0.63)$ & $(0.45)$ & $(0.66)$ \\
\hline \multirow[t]{2}{*}{ Unidentified Caddis } & 465 & 61 & 4 & 6 & 5 & 1 \\
\hline & $(4.95)$ & $(1.60)$ & $(0.56)$ & $(1.88)$ & $(3.68)$ & $(1.48)$ \\
\hline
\end{tabular}


Table 5. (Continued)

\begin{tabular}{|c|c|c|c|c|c|c|}
\hline \multirow[b]{2}{*}{ Taxon } & \multicolumn{6}{|c|}{ Zone $^{\mathrm{a}}$} \\
\hline & $\mathbf{A}$ & B & $\mathbf{C}$ & D & $\mathbf{E}$ & $\mathbf{F}$ \\
\hline \multicolumn{7}{|l|}{ Lepidoptera } \\
\hline \multirow[t]{2}{*}{ Pyralidae } & 4 & 3 & 1 & 0 & 0.30 & 0 \\
\hline & $(0.04)$ & $(0.09)$ & $(0.16)$ & $(0.00)$ & $(0.24)$ & $(0.00)$ \\
\hline \multicolumn{7}{|l|}{ Diptera } \\
\hline \multirow[t]{2}{*}{ Chironomidae } & 4897 & 2467 & 629 & 236 & 82 & 40 \\
\hline & $(52.07)$ & $(64.94)$ & $(78.91)$ & $(77.10)$ & $(65.45)$ & $(51.91)$ \\
\hline \multicolumn{7}{|l|}{ Arachnida } \\
\hline \multirow[t]{2}{*}{ Hydracarina } & 235 & 217 & 34 & 8 & 2 & 1 \\
\hline & $(2.50)$ & $(5.72)$ & $(4.22)$ & $(2.57)$ & $(1.51)$ & $(1.73)$ \\
\hline \multicolumn{7}{|l|}{ Mollusca } \\
\hline \multirow[t]{2}{*}{ Gastropoda } & 29 & 8 & 1 & 1 & 1 & 4 \\
\hline & $(0.31)$ & $(0.22)$ & $(0.11)$ & $(0.36)$ & $(0.71)$ & $(4.63)$ \\
\hline Total Density (\#/m²) & 9363 & 3871 & 779 & 340 & 132 & 76 \\
\hline$\%$ Reduction by Density ${ }^{\mathrm{b}}$ & 0.0 . & 58.66 & 91.68 & 96.37 & 98.59 & 99.19 \\
\hline \% Midge by Density & 52.07 & 64.94 & 78.91 & 77.10 & 65.45 & 51.91 \\
\hline Total Biomass ( $\left.\mathrm{g} / \mathrm{m}^{2}\right)$ & 0.6686 & 0.2357 & 0.0516 & 0.0250 & 0.0127 & 0.0054 \\
\hline$\%$ Reduction by Biomass $^{c}$ & 0.0 & 64.75 & 92.28 & 96.26 & 98.10 & 99.19 \\
\hline \% Midge by Biomass & 19.99 & 37.63 & 50.47 & 54.10 & 45.40 & 38.99 \\
\hline Total Taxa & 8 & 7 & 4 & 3 & 3 & 2 \\
\hline Total Individuals ${ }^{\mathrm{d}}$ & 718 & 295 & 61 & 24 & 10 & 6 \\
\hline Taxonomic Diversity ${ }^{\mathrm{e}}$ & 1.10 & 1.08 & 0.83 & 0.70 & 0.84 & 0.78 \\
\hline
\end{tabular}

${ }^{a}$ Hours of exposure by zone: A, 0; B, 1-24; C, 25-72; D, 73-168; E, 169-360; F, >361.

${ }^{\mathrm{b}}$ Percent (\%) reduction in mean total density or mean total biomass ${ }^{\mathrm{c}}$ of given exposure treatment relative to control treatment.

${ }^{\mathrm{d}}$ Mean absolute number of individuals collected (for diversity computations).

${ }^{\mathrm{e}}$ Taxonomic diversity index (D) $=(\mathrm{S}-1) / \log _{\mathrm{e}} \mathrm{N}$, where $\mathrm{S}=$ number of taxa present and $\mathrm{N}=$ number of individuals. 
Table 6. Checklist of mean density $\left(\right.$ No. $\left./ \mathrm{m}^{2}\right)$ of macro-invertebrate taxa along a longterm exposure test transect. Mean values of total density and biomass; total percent reduction and percent midge by density and biomass, total taxa, total individuals, and taxonomic diversity for site 1 (Locke Island).

\begin{tabular}{|c|c|c|c|c|c|c|c|}
\hline \multirow[b]{2}{*}{ Taxon } & & \multicolumn{6}{|c|}{ Zone $^{\mathrm{a}}$} \\
\hline & & $\mathbf{A}$ & B & $\mathbf{C}$ & D & $\mathbf{E}$ & $\mathbf{F}$ \\
\hline \multirow[t]{4}{*}{ Density $\left(\# / \mathrm{m}^{2}\right)$} & Midge & 7553 & 1666 & 644 & 331 & 131 & 47 \\
\hline & Caddis & 3561 & 379 & 33 & 35 & 27 & 14 \\
\hline & Other & 1502 & 546 & 61 & 25 & 15 & 7 \\
\hline & Total & 12617 & 2592 & 700 & 457 & 174 & 69 \\
\hline \multicolumn{2}{|c|}{ Total \%Reduction ${ }^{b}$} & 0.00 & 79.46 & 94.45 & 96.38 & 98.62 & 99.46 \\
\hline \multicolumn{2}{|r|}{ \% Midge } & 57.55 & 71.95 & 85.84 & 82.87 & 70.71 & 52.22 \\
\hline \multirow[t]{4}{*}{$\operatorname{Biomass}\left(\mathrm{g} / \mathrm{m}^{2}\right)$} & Midge & 0.2312 & 0.1001 & 0.0420 & 0.0237 & 0.0113 & 0.0033 \\
\hline & Caddis & 0.4330 & 0.0814 & 0.0106 & 0.0077 & 0.0049 & 0.0012 \\
\hline & Other & 0.2276 & 0.0585 & 0.0133 & 0.0086 & 0.0053 & 0.0019 \\
\hline & Total & 0.8918 & 0.2400 & 0.0657 & 0.0429 & 0.0215 & 0.0065 \\
\hline \multicolumn{2}{|c|}{ Total \%Reduction ${ }^{\mathrm{c}}$} & 0.00 & 73.09 & 92.63 & 95.19 & 97.58 & 99.27 \\
\hline \multicolumn{2}{|r|}{ \% Midge } & 29.33 & 44.99 & 60.34 & 63.52 & 59.89 & 46.63 \\
\hline \multicolumn{2}{|l|}{ Total Taxa } & 8 & 7 & 4 & 3 & 3 & 2 \\
\hline \multicolumn{2}{|c|}{ Total Individuals ${ }^{\mathrm{d}}$} & 970 & 197 & 56 & 30 & 13 & 5 \\
\hline \multicolumn{2}{|c|}{ Taxonomic Diversity $^{\mathrm{e}}$} & 1.08 & 1.18 & 0.70 & 0.71 & 0.70 & 0.41 \\
\hline
\end{tabular}

${ }^{a}$ Hours of exposure by zone: A, 0; B, 1-24; C, 25-72; D, 73-168; E, 169-360; F, >361.

${ }^{\mathrm{b}}$ Percent $(\%)$ reduction in mean total density or mean total biomass ${ }^{\mathrm{c}}$ of given exposure treatment relative to control treatment.

${ }^{d}$ Mean absolute number of individuals collected (for diversity computations).

${ }^{\mathrm{e}}$ Taxonomic diversity index $(\mathrm{D})=(\mathrm{S}-1) / \log _{\mathrm{e}} \mathrm{N}$, where $\mathrm{S}=$ number of taxa present and $\mathrm{N}=$ number of individuals. 
Table 7. Checklist of mean density $\left(\mathrm{No} . / \mathrm{m}^{2}\right)$ of macroinvertebrate taxa along a long-term exposure test transect. Mean values of total density and biomass, percent reduction and percent midge by density and biomass, total taxa, total individuals, and taxonomic diversity for Site 2 (F-Island).

\begin{tabular}{|c|c|c|c|c|c|c|c|}
\hline \multirow[b]{2}{*}{ Taxon } & & \multicolumn{6}{|c|}{ Zone $^{\mathrm{a}}$} \\
\hline & & $\mathbf{A}$ & B & $\mathbf{C}$ & D & $\mathbf{E}$ & $\mathbf{F}$ \\
\hline \multirow[t]{4}{*}{ Density (\#/m²) } & Midge & 2240 & 3268 & 614 & 141 & 33 & 32 \\
\hline & Caddis & 2116 & 1041 & 90 & 28 & 22 & 26 \\
\hline & Other & 1744 & 840 & 151 & 52 & 23 & 25 \\
\hline & Total & 6108 & 5150 & 858 & 222 & 90 & 84 \\
\hline \multicolumn{2}{|c|}{ Total \%Reduction ${ }^{b}$} & 0.00 & 15.69 & 85.96 & 96.36 & 98.52 & 98.63 \\
\hline \multicolumn{2}{|r|}{ \% Midge } & 33.58 & 59.35 & 66.07 & 61.83 & 43.87 & 33.66 \\
\hline \multirow[t]{4}{*}{$\operatorname{Biomass}\left(\mathrm{g} / \mathrm{m}^{2}\right)$} & Midge & 0.0437 & 0.0718 & 0.0125 & 0.0025 & 0.0010 & 0.0010 \\
\hline & Caddis & 0.2802 & 0.0866 & 0.0190 & 0.0026 & 0.0016 & 0.0020 \\
\hline & Other & 0.1215 & 0.0731 & 0.0061 & 0.0020 & 0.0012 & 0.0013 \\
\hline & Total & 0.4454 & 0.2315 & 0.0375 & 0.0071 & 0.0038 & 0.0044 \\
\hline \multicolumn{2}{|c|}{ Total \%Reduction ${ }^{c}$} & 0.00 & 48.04 & 91.58 & 98.40 & 99.15 & 99.02 \\
\hline \multicolumn{2}{|r|}{ \% Midge } & 10.64 & 30.26 & 40.61 & 44.68 & 30.91 & 31.35 \\
\hline \multicolumn{2}{|l|}{ Total Taxa } & 8 & 7 & 5 & 3 & 3 & 3 \\
\hline \multicolumn{2}{|c|}{ Total Individuals ${ }^{\mathrm{d}}$} & 466 & 393 & 65 & 17 & 6 & 6 \\
\hline \multicolumn{2}{|c|}{ Taxonomic Diversity $^{\mathrm{e}}$} & 1.14 & 1.00 & 0.96 & 0.71 & 1.12 & 1.12 \\
\hline \multicolumn{8}{|c|}{$\begin{array}{l}{ }^{\mathrm{a}} \text { Hours of exposure by zone: A, } 0 ; \mathrm{B}, 1-24 ; \mathrm{C}, 25-72 ; \mathrm{D}, 73-168 ; \mathrm{E}, 169-360 ; \mathrm{F},>361 . \\
{ }^{\mathrm{b}} \text { Percent }(\%) \text { reduction in mean total density or mean total biomass }{ }^{\mathrm{c}} \text { of given exposure }\end{array}$} \\
\hline
\end{tabular}


Table 8. Required sample size (n) to estimate benthic macroinvertebrate mean density to within the specified accuracy of the true mean, for each combination of substrate, colonization, and site.

\begin{tabular}{|c|c|c|c|c|c|}
\hline \multirow{2}{*}{ Site } & \multirow{2}{*}{$\begin{array}{c}\text { Specified } \\
\text { Accuracy }\end{array}$} & \multicolumn{3}{|c|}{ Sample Size (n) Needed: (\# of samples) } \\
\cline { 3 - 6 } & of Mean & $\mathbf{3}$ wk & $\mathbf{6}$ wk & $\mathbf{4}$ wk & $\mathbf{6}$ wk \\
\cline { 3 - 6 } & $+/-10$ & 84 & 431 & 141 & 91 \\
$\mathbf{1}$ & $+/-20$ & 21 & 108 & 35 & 23 \\
& $+/-30$ & 9 & 48 & 16 & 10 \\
\hline \multirow{2}{*}{$\mathbf{3}$} & $+/-10$ & 57 & 102 & 105 & 175 \\
& $+/-20$ & 14 & 26 & 26 & 44 \\
& $+/-30$ & 6 & 11 & 12 & 19 \\
\hline \multirow{3}{*}{} & $+/-10$ & 782 & 253 & 786 & 231 \\
& $+/-20$ & 196 & 63 & 197 & 58 \\
& $+/-30$ & 87 & 28 & 87 & 26 \\
\hline
\end{tabular}


Appendix 1. Checklist of benthic macroinvertebrate taxa collected on artificial substrata in the Hanford Reach, Columbia River, categorized by percent occurence in samples.

\begin{tabular}{|c|c|c|c|c|c|}
\hline Taxa & Brick & BBQ & Site 1 & Site 2 & Site 3 \\
\hline $\begin{array}{l}\text { Cnidaria } \\
\text { Hydrozoa }\end{array}$ & $\mathrm{R}$ & $\mathrm{U}$ & 0 & $\mathrm{R}$ & $\mathrm{C}$ \\
\hline Turbellaria (flatworms) & $\mathrm{C}$ & A & $\mathrm{U}$ & A & $\mathrm{A}$ \\
\hline Nematoda (roundworms) & $\mathrm{A}$ & A & A & A & $\mathrm{A}$ \\
\hline $\begin{array}{l}\text { Annelida } \\
\text { Oligochaeta (earthworms) }\end{array}$ & A & A & A & A & A \\
\hline $\begin{array}{l}\text { Arthropoda } \\
\text { Crustacea } \\
\text { Amphipoda (scuds) }\end{array}$ & $\mathrm{R}$ & 0 & 0 & 0 & $\mathrm{R}$ \\
\hline $\begin{array}{l}\text { Insecta } \\
\text { Collembola (springtails) }\end{array}$ & 0 & $\mathrm{R}$ & 0 & 0 & $\mathrm{R}$ \\
\hline Ephemeroptera (mayflies) & A & A & A & A & A \\
\hline $\begin{array}{l}\text { Trichoptera (caddisflies) } \\
\text { Hydropsychidae } \\
\text { Hydropsyche spp. } \\
\text { Cheumatopysche spp. }\end{array}$ & A & A & A & $\mathrm{A}$ & A \\
\hline $\begin{array}{l}\text { Hydroptilidae } \\
\text { Hydroptila spp. }\end{array}$ & A & A & $\mathrm{C}$ & A & A \\
\hline $\begin{array}{l}\text { Leptoceridae } \\
\text { Oecetis spp. }\end{array}$ & $\mathrm{C}$ & $\mathrm{C}$ & $\mathrm{C}$ & $\mathrm{C}$ & $\mathrm{C}$ \\
\hline $\begin{array}{l}\text { Psychomyiidae } \\
\text { Psychomyia spp. }\end{array}$ & $\mathrm{C}$ & $\mathrm{C}$ & $\mathrm{U}$ & A & $\mathrm{C}$ \\
\hline $\begin{array}{l}\text { Lepidoptera } \\
\text { Pyralidae (butterfly larvae) }\end{array}$ & $\mathrm{C}$ & $\mathrm{C}$ & $\mathrm{U}$ & $\mathrm{C}$ & $\mathrm{C}$ \\
\hline $\begin{array}{l}\text { Diptera } \\
\text { Chironomidae (midges) }\end{array}$ & A & A & A & A & $\mathrm{A}$ \\
\hline $\begin{array}{l}\text { Arachnida } \\
\text { Hydracarina (water mites) }\end{array}$ & A & A & A & A & A \\
\hline $\begin{array}{l}\text { Mollusca } \\
\text { Gastropoda (snails) } \\
\text { Pelecypoda (mussels) }\end{array}$ & $\begin{array}{l}\mathrm{C} \\
\mathrm{R}\end{array}$ & $\begin{array}{l}\mathrm{U} \\
\mathrm{R}\end{array}$ & $\begin{array}{l}\mathrm{R} \\
0\end{array}$ & $\begin{array}{l}\mathrm{C} \\
\mathrm{R}\end{array}$ & $\begin{array}{l}\mathrm{C} \\
\mathrm{R}\end{array}$ \\
\hline
\end{tabular}

a $(0)=$ absent from samples

$\mathrm{b}(\mathrm{R})=$ rare, found in less than $10 \%$ of samples

c $(\mathrm{U})=$ uncommon, found in 10 to $30 \%$ of samples

$\mathrm{d}(\mathrm{C})=$ common, found in 30 to $60 \%$ of samples

e $(A)=$ abundant, found in $60 \%$ or more of samples 
Appendix 2. Statistical results (p-values and degrees freedom in parenthesis) from a partially-nested analysis of variance (ANOVA) of invertebrate taxa group mean density and biomass (Bio) with exposure treatment groups for both sites.

\begin{tabular}{lcccccccc}
\hline & \multicolumn{2}{c}{ MIDGE } & \multicolumn{2}{c}{ CADDIS } & \multicolumn{2}{c}{ 'OTHER' } & \multicolumn{2}{c}{ TOTAL } \\
\cline { 2 - 8 } EFFECT & Density & Bio & Density & Bio & Density & Bio & Density & Bio \\
\hline Model r & $\mathbf{0 . 9 3}$ & $\mathbf{0 . 8 7}$ & $\mathbf{0 . 9 2}$ & $\mathbf{0 . 8 5}$ & $\mathbf{0 . 9 4}$ & $\mathbf{0 . 7 0}$ & $\mathbf{0 . 9 6}$ & $\mathbf{0 . 9 4}$ \\
$\begin{array}{l}\text { Site } \\
(\mathrm{df}=1)\end{array}$ & $\mathbf{0 . 0 0 9}$ & $\mathbf{0 . 0 0 0 1}$ & 0.12 & 0.08 & $\mathbf{0 . 0 0 4}$ & 0.44 & 0.45 & $\mathbf{0 . 0 0 4}$ \\
$\begin{array}{l}\text { Trt } \\
(\mathrm{df}=5)\end{array}$ & $\mathbf{0 . 0 0 0 1}$ & $\mathbf{0 . 0 0 0 1}$ & $\mathbf{0 . 0 0 0 1}$ & $\mathbf{0 . 0 0 0 1}$ & $\mathbf{0 . 0 0 0 1}$ & $\mathbf{0 . 0 0 0 1}$ & $\mathbf{0 . 0 0 0 1}$ & $\mathbf{0 . 0 0 0 1}$ \\
$\begin{array}{l}\text { Site*Trt } \\
(\mathrm{df}=5)\end{array}$ & $\mathbf{0 . 0 1}$ & $\mathbf{0 . 0 0 0 1}$ & $\mathbf{0 . 0 4}$ & $\mathbf{0 . 0 0 0 1}$ & $\mathbf{0 . 0 3}$ & 0.47 & $\mathbf{0 . 0 0 0 1}$ & $\mathbf{0 . 0 0 0 1}$ \\
\hline \multicolumn{3}{c}{$\alpha=0.05$ level of significance } \\
\end{tabular}


Appendix 3. Statistical results (p-values and degrees freedom) from a partially-nested analysis of variance (ANOVA) of the average weight of invertebrate taxa categories with exposure treatment groups for both sites.

\begin{tabular}{lccc}
\hline \hline Effect & MIDGE & CADDIS & 'OTHER' \\
\hline Model $\mathbf{r}^{\mathbf{2}}$ & $\mathbf{0 . 7 2}$ & $\mathbf{0 . 8 7}$ & $\mathbf{0 . 6 1}$ \\
$\begin{array}{l}\text { Site } \\
(\mathrm{df}=1)\end{array}$ & $\mathbf{0 . 0 0 0 1}$ & 0.16 & $\mathbf{0 . 0 3}$ \\
$\begin{array}{l}\mathbf{T r t} \\
(\mathrm{df}=5)\end{array}$ & $\mathbf{0 . 0 3}$ & 0.18 & 0.12 \\
$\begin{array}{l}\text { Site * } \mathbf{T r t} \\
(\mathrm{df}=5)\end{array}$ & $\mathbf{0 . 0 0 6}$ & 0.29 & 0.57 \\
\hline
\end{tabular}

$\alpha=0.05$ level of significance

Appendix 4. Statistical results (degrees freedom and p-values) from a partially-nested analysis of variance (ANOVA) of the effect of exposure duration (treatment) on invertebrate taxa group mean density and biomass (Bio) for site 1 (Locke-Island) only.

\begin{tabular}{lcccccccc}
\hline & \multicolumn{2}{c}{ MIDGE } & \multicolumn{2}{c}{ CADDIS } & \multicolumn{2}{c}{ 'OTHER' } & \multicolumn{2}{c}{ TOTAL } \\
\cline { 2 - 8 } EFFECT & Density & Bio & Density & Bio & Density & Bio & Density & Bio \\
\hline Model $\mathbf{r}^{2}$ & $\mathbf{0 . 9 4}$ & $\mathbf{0 . 8 4}$ & $\mathbf{0 . 9 3}$ & $\mathbf{0 . 8 3}$ & $\mathbf{0 . 9 4}$ & $\mathbf{0 . 6 0}$ & $\mathbf{0 . 9 7}$ & 0.94 \\
$\begin{array}{l}\text { Trt } \\
(\mathrm{df}=5)\end{array}$ & $\mathbf{0 . 0 0 0 1}$ & $\mathbf{0 . 0 0 0 1}$ & $\mathbf{0 . 0 0 0 1}$ & $\mathbf{0 . 0 0 0 1}$ & $\mathbf{0 . 0 0 0 1}$ & $\mathbf{0 . 0 0 0 1}$ & $\mathbf{0 . 0 0 0 1}$ & $\mathbf{0 . 0 0 0 1}$ \\
\hline$\alpha=0.05$ level of significance & & & & & & \\
\hline
\end{tabular}


Appendix 5. Least Squares Means pairwise comparisons of midge, caddis, and 'other' groups mean density and biomass from site 1 (Locke Island) and site 2 (F-Island).

F-Island

MIDGE DENSITY

Locke-Island

$\begin{array}{llllll}\mathrm{A} & \mathrm{B} & \mathrm{C} & \mathrm{D} & \mathrm{E} & \mathrm{F}\end{array}$

A $\quad$ B $\quad \underline{C} \quad$ D $\quad$ E $\quad F$

F-Island

MIDGE BIOMASS

Locke-Island

$\begin{array}{llllll}\mathrm{A} & \mathrm{B} & \mathrm{C} & \underline{\mathrm{D}} & \mathrm{E} & \mathrm{F}\end{array}$

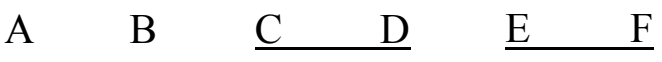

F-Island

CADDIS DENSITY

Locke-Island

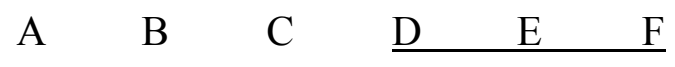

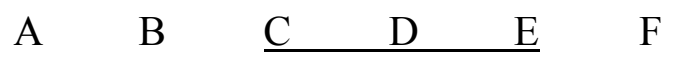

F-Island

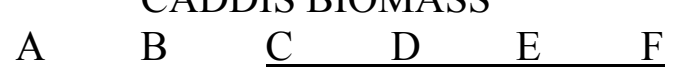

Locke-Island
A
B
$\underline{\mathrm{C}}$
D $\quad$ E $\quad$ F

F-Island

\section{A 'OTHER' DENSITY}

\begin{tabular}{|c|c|c|}
\hline & C \\
\hline
\end{tabular}

Locke-Island

A $\quad$ B $\quad$ C $\quad \underline{D} \quad$ E $\quad F$

F-Island

\begin{tabular}{llllll}
$\mathrm{A}$ & $\mathrm{B}$ & $\mathrm{C}$ & $\mathrm{D}$ & $\mathrm{E}$ & $\mathrm{F}$ \\
\hline
\end{tabular}

Locke-Island
A B
B
C D E
E $\quad \mathrm{F}$

${ }^{\mathrm{a}}$ Hours of exposure by zone: A, 0; B, 1-24; C, 25-72; D, 73-168; E, 169-360; F, >361.

${ }^{\mathrm{b}}$ Treatments not underscored by the same line were found to have significantly different densities or biomass respectively $(\alpha=0.05$ significance level). 
Appendix 6. Statistical results ( $p$-values and degrees of freedom in parenthesis) from a partially-nested analysis of variance (ANOVA) of the average weight of invertebrate taxa categories with exposure treatment groups, for sites I and II separately.

\begin{tabular}{lcccccc}
\hline Effect & \multicolumn{2}{c}{ MIDGE } & \multicolumn{2}{c}{ CADDIS } & \multicolumn{2}{c}{ 'OTHER' } \\
\hline Sites & F & L & F & L & F & L \\
Model r ${ }^{2}$ & $\mathbf{0 . 6 1}$ & $\mathbf{0 . 6 8}$ & $\mathbf{0 . 7 7}$ & $\mathbf{0 . 8 9}$ & $\mathbf{0 . 7 7}$ & $\mathbf{0 . 5 9}$ \\
$\begin{array}{l}\text { Treatment } \\
(\text { df }=5)\end{array}$ & 0.73 & $\mathbf{0 . 0 0 4}$ & $\mathbf{0 . 0 4}$ & 0.17 & $\mathbf{0 . 0 0 0 1}$ & 0.30 \\
\end{tabular}

$\alpha=0.05$ level of significance

Appendix 7. Statistical results (p-values and degrees of freedom in parenthesis) from a partially-nested analysis of variance (ANOVA) of invertebrate taxa group mean density and biomass with exposure treatment groups for site 2 (F-Island) only.

\begin{tabular}{lcccccccc}
\hline & \multicolumn{2}{c}{ MIDGE } & \multicolumn{2}{c}{ CADDIS } & \multicolumn{2}{c}{ 'OTHER' } & \multicolumn{2}{c}{ TOTAL } \\
\cline { 2 - 8 } EFFECT & Density & StCrop & Density & StCrop & Density & StCrop & Density & StCrop \\
\hline Model r $\mathbf{r}^{2}$ & $\mathbf{0 . 9 4}$ & $\mathbf{0 . 8 2}$ & $\mathbf{0 . 9 4}$ & $\mathbf{0 . 8 2}$ & $\mathbf{0 . 9 5}$ & $\mathbf{0 . 9 0}$ & $\mathbf{0 . 9 5}$ & $\mathbf{0 . 9 0}$ \\
$\begin{array}{l}\text { Trt } \\
(\mathrm{df}=5)\end{array}$ & $\mathbf{0 . 0 0 0 1}$ & $\mathbf{0 . 0 0 0 1}$ & $\mathbf{0 . 0 0 0 1}$ & $\mathbf{0 . 0 0 0 1}$ & $\mathbf{0 . 0 0 0 1}$ & $\mathbf{0 . 0 0 0 1}$ & $\mathbf{0 . 0 0 0 1}$ & $\mathbf{0 . 0 0 0 1}$ \\
\hline$\alpha=0.05$ level of significance & & & & & & & \\
\hline
\end{tabular}


Appendix 8. Statistical results ( $\mathrm{p}$-values and degrees freedom in parenthesis)) from a factorial analysis of covariance (ANCOVA) to test for the effect of discharge, and a partially-nested analysis of variance (ANOVA) to test for the effects of depth and time of day (diel) on invertebrate drift density from nearshore drift sampling, August 17-18 and 27-29, 1999 at site 1 (Locke-Island) in the Hanford Reach, Columbia River, Washington.

\begin{tabular}{ccccc}
\hline \hline Effect & MIDGE & CADDIS & 'OTHER' & TOTAL \\
\hline $\begin{array}{c}\text { Discharge } \\
(\mathrm{df}=27)\end{array}$ & $\mathbf{0 . 0 0 8}$ & 0.19 & 0.06 & $\mathbf{0 . 0 0 8}$ \\
$\begin{array}{c}\text { Depth } \\
(\mathrm{df}=2)\end{array}$ & $<\mathbf{0 . 0 0 0 1}$ & $<\mathbf{0 . 0 0 0 1}$ & $<\mathbf{0 . 0 0 0 1}$ & $<\mathbf{0 . 0 0 0 1}$ \\
$\begin{array}{c}\text { Diel } \\
(\mathrm{df}=3)\end{array}$ & 0.22 & $\mathbf{0 . 0 0 5}$ & 0.89 & 0.55 \\
\hline
\end{tabular}

$\alpha=0.05$ level of significance

Appendix 9. Statistical results (p-values and degrees freedom in parenthesis) from a factorial analysis of covariance (ANCOVA) to test for the effect of discharge, and a partially-nested analysis of variance (ANOVA) to test for the effects of depth and time of day (diel) on invertebrate drift density from boat drift sampling, August 27-29, 1999 at site 1 (Locke-Island) in the Hanford Reach, Columbia River, Washington.

\begin{tabular}{ccccc}
\hline \hline Effect & MIDGE & CADDIS & 'OTHER' & TOTAL \\
\hline $\begin{array}{c}\text { Discharge } \\
(\mathrm{df}=11)\end{array}$ & 0.19 & 0.89 & 0.72 & 0.53 \\
$\begin{array}{c}\text { Depth } \\
(\mathrm{df}=1) \\
\begin{array}{c}\text { Diel } \\
(\mathrm{df}=3)\end{array}\end{array}$ & 0.65 & 0.92 & 0.06 & 0.43 \\
\hline
\end{tabular}

$\alpha=0.05$ level of significance 
Appendix 10. Statistical results ( $p$-values and degrees freedom in parenthesis) from a factorial analysis of variance (ANOVA) of average mortality rates of invertebrate taxa groups found on both brick and tile substrata under different exposure treatment groups.

\begin{tabular}{lcccc}
\hline Effect & MIDGE & CADDIS & 'OTHER' & TOTAL \\
\hline $\begin{array}{l}\text { Trt } \\
(\mathrm{df}=8)\end{array}$ & $<\mathbf{0 . 0 0 0 1}$ & $<\mathbf{0 . 0 0 0 1}$ & $<\mathbf{0 . 0 0 0 1}$ & $<\mathbf{0 . 0 0 0 1}$ \\
$\begin{array}{l}\text { Sub } \\
(\mathrm{df}=1)\end{array}$ & 0.22 & $\mathbf{0 . 0 4}$ & $\mathbf{0 . 0 2}$ & $\mathbf{0 . 0 1}$ \\
$\begin{array}{l}\text { Sub } * \text { Trt } \\
(\mathrm{df}=8)\end{array}$ & 0.11 & $\mathbf{0 . 0 3}$ & $\mathbf{0 . 0 0 9}$ & $\mathbf{0 . 0 2}$ \\
\hline
\end{tabular}

$\alpha=0.05$ level of significance

Appendix 11. Statistical results (p-values and degrees freedom) from an analysis of variance (ANOVA) of the average mortality rates of invertebrate taxa categories with exposure treatment groups, sites separate.

\begin{tabular}{lcccccc}
\hline \hline Effect & \multicolumn{2}{c}{ MIDGE } & \multicolumn{2}{c}{ CADDIS } & \multicolumn{2}{c}{ 'OTHER' } \\
\hline Substrate & Brick & Tile & Brick & Tile & Brick & Tile \\
Trt & & & & & & \\
$(\mathrm{df}=8)$ & $<.0001$ & $<\mathbf{0 . 0 0 0 1}$ & $<\mathbf{0 . 0 0 0 1}$ & $<\mathbf{0 . 0 0 0 1}$ & $\mathbf{0 . 0 0 0 6}$ & $<\mathbf{0 . 0 0 0 1}$ \\
\hline
\end{tabular}

$\alpha=0.05$ level of significance 


\section{Appendix F}

Effects of Semi-acute Thermal Stressors on the Survival, Predator Avoidance Ability, Stress Physiology, and Heat Shock Protein Expression of Juvenile Fall Chinook Salmon 
Effects of semi-acute thermal stressors on the survival, predator avoidance ability, stress physiology, and heat shock protein expression of juvenile fall chinook salmon

\author{
Matthew G. Mesa ${ }^{*}$, Lisa K. Weiland \\ US Geological Survey, Biological Resources Division \\ Western Fisheries Research Center \\ Columbia River Research Laboratory \\ 5501A Cook-Underwood Rd. \\ Cook, WA 98605 \\ and Paul Wagner ${ }^{1}$ \\ Washington Department of Fish and Wildlife \\ 500 N. Moraine St., Suite 1200E \\ Kennewick, WA 99336
}

*Corresponding author: matt_mesa@usgs.gov

${ }^{1}$ Present address: Golder Associates, P.O. Box 73, Plymouth, WA 99346 


\begin{abstract}
We exposed juvenile fall chinook salmon (Oncorhynchus tshawytscha) from the Hanford Reach—the last free flowing section of the Columbia River-to thermal stressors in the laboratory that were derived from actual field data and assessed the effects of such stressors on: (1) the extent of direct mortality; (2) the vulnerability of fish to predation by smallmouth bass (Micropterus dolomieui); and (3) some general physiological stress responses and synthesis of heat shock protein 70 (hsp70). Thermally- stressed fish showed little direct mortality and no increases in vulnerability to predation. However, these fish showed transient increases in plasma concentrations of cortisol, glucose, and lactate, and a dramatic (25-fold higher than controls) and persistent (lasting 2 weeks) increase in levels of liver hsp70. Although our results may suggest that such stressors pose no serious threat to these fish, we are concerned about other effects and types of thermal stressors not addressed in this study and, perhaps more importantly, the consequences of exposure of fish to multiple, cumulative stressors.
\end{abstract}

\title{
Introduction
}

The Hanford Reach is the last free flowing section of the Columbia River and supports a large and important population of wild fall chinook salmon (Oncorhynchus tshawytscha). Recently, substantial concerns have been raised about potential losses of these fish due to river level fluctuations resulting from power peaking operations at hydroelectric facilities. Rapid fluctuations in river level can cause stranding (i.e., the trapping of fish on or within the unwatered substrate as a result of receding river level) of juvenile fall chinook salmon and lead to direct, rapid mortality. Indeed, such stranding 
has been observed in the Hanford Reach by us and has also been documented in other rivers during controlled drawdown experiments (Thompson 1970; Phinney 1974; Tipping et al. 1978; Woodin 1984).

Besides stranding, fish can also become entrapped in isolated backwaters that form when water rapidly recedes. Although entrapment (defined as separation of fish from the main river channel in enclosed backwater areas as a result of receding river level) may not cause direct, rapid mortality, it may lead to delayed mortality from two indirect sources_-predation and alterations in performance caused by sublethal heat stress. Predation by birds and fish on juvenile salmon entrapped in pools has been observed by us on several occasions in the Hanford Reach. Such predation could be substantial in these shallow, isolated backwaters since prey have few options with which to counter the intense predation pressure. To date, however, there have been no quantitative studies addressing the magnitude of avian and piscine predation on juvenile salmon in these temporary backwaters.

Alterations in performance of fish caused by sublethal heat stress is a more insidious, yet potentially devastating, effect of entrapment and was the focus of our research. Fish entrapped in backwaters on the Hanford Reach can experience a unique type of thermal stressor, typically consisting of exposure to gradual (i.e., over several hours) and extreme (e.g., $>10^{\circ} \mathrm{C}$ above ambient temperatures) increases in temperature followed by an abrupt decrease in temperature when they are liberated into the main river as water levels rapidly rise. Sublethal, acute thermal shocks are known to increase the vulnerability of fish to predation (Sylvester 1972; Coutant 1973; Yocom and Edsall 1974; Deacutis 1978), cause a variety of physiological disturbances in fish (Wedemeyer 1973; 
Strange et al. 1977; Crawshaw 1977; Crawshaw 1979; Bailey et al. 1991; Soncini and Glass 1997), and elicit the rapid synthesis of stress proteins that play a role in repair and protection from environmentally induced cellular damage (Sanders 1993; Iwama et al. 1998). However, information from such studies may not be applicable to fall chinook salmon in the Hanford Reach because of species, age, and the unique nature of the stressor experienced by these fish. Clearly, such a stressor has the potential to alter behavioral and physiological mechanisms of fish that could lead to delayed, direct or indirect mortality. An understanding of the effects of a semi-acute heat stress on juvenile fall chinook salmon — at several levels of organization — is necessary to not only assess the impacts of entrapment on populations of these fish in the Hanford Reach, but will also contribute to our knowledge of thermal stressors in general.

For this research, we exposed juvenile fall chinook salmon from the Hanford Reach to heat stress scenarios in the laboratory that were derived from actual field data. We then assessed the effects of such thermal stressors on: (1) the extent of direct mortality; (2) the vulnerability of fish to predation by smallmouth bass (Micropterus dolomieui); and (3) some general physiological stress responses and synthesis of heat shock protein 70 (hsp70).

\section{Methods and Materials}

\section{Test fish}

Subyearling fall chinook salmon were collected by seine from the Hanford Reach during April and May in 1998 and 1999. Fish were transported to our laboratory in a truck equipped with a large aluminum tank and aerated water and initially averaged $( \pm$ SE) $38.25 \pm 0.57 \mathrm{~mm}$ in length and $0.68 \pm 0.05 \mathrm{~g}$ in weight. The fish were placed in 
1400 L flow-through circular tanks, reared outdoors under ambient photoperiod, and were fed twice daily (at a ration of 3-4 \% body weight per day) with blood worms for the first month and a commercial starter feed thereafter.

Smallmouth bass (average length $\pm \mathrm{SE}=306.0 \pm 6.4 \mathrm{~mm}$; weight $=457 \pm 27 \mathrm{~g} ; N$ =16) were used in our predation trials and were collected by angling from the lower Yakima River, Washington, in 1998 and by electrofishing in the Columbia River in 1999. They were transported to our laboratory as previously described and placed in each of two 3.75-m-diameter, 1-m-deep circular tanks ( $N=4$ fish per tank) which were lined with gravel and cobble substrates and four pieces of 0.25-m-long, 15-cm-diameter PVC pipe randomly scattered along the bottom to serve as cover. These tanks served as our predation arenas and were surrounded with curtains to minimize outside disturbance and under an ambient photoperiod simulated with $25 \mathrm{~W}$ incandescent bulbs and timers to produce a gradual intensity dawn and dusk. Predators were fed a maintenance diet of juvenile chinook salmon (about 2 fish per predator every 2-3 d). All fish were acclimated to and held in well water heated to $12^{\circ} \mathrm{C}$, which was representative of river temperatures in the Hanford Reach during spring. The water was heated using large, single-pass electric heaters and excess dissolved gas generated by heating was dissipated by a packed column.

\section{Direct mortality bioassays}

Fall chinook salmon used in these tests, which were conducted during June and July in 1999, had an average length $( \pm \mathrm{SE})$ of $55.45 \pm 0.36 \mathrm{~mm}$ and a weight of $1.48 \pm$ $0.03 \mathrm{~g}(N=160)$. Four groups of fish ( $N=20$ per group) were serially removed from their holding tank, placed in a 19 L bucket filled with water, and transferred to one of 
four $0.61-\mathrm{m}$-diameter circular test tanks. Two of these tanks contained a $2000 \mathrm{~W}$ immersion heater connected to an electronic controller that was used to produce the thermal stressors (described below). All tanks received the same water as the holding tanks with an inflow of about $1 \mathrm{~L} / \mathrm{min}$ and a volume of $104 \mathrm{~L}$. Densities in the test tanks were about $0.28 \mathrm{~g} / \mathrm{L}$. Fish were held undisturbed for at least $2 \mathrm{~d}$ prior to starting a bioassay.

To start a bioassay, fish in the two tanks with heaters were designated as treatment fish, whereas fish in the other tanks remained at $12^{\circ} \mathrm{C}$ during the experiment and were designated as controls. At 0700, fish in the treatment tanks were subjected to one of four thermal stressors in separate trials (Fig. 1). The first stressor consisted of heating the water from $12^{\circ} \mathrm{C}$ to $26^{\circ} \mathrm{C}$ at a rate of $2^{\circ} \mathrm{C} / \mathrm{h}$, followed by a decrease to $12^{\circ} \mathrm{C}$ in about $1 \mathrm{~h}$ (hereinafter referred to as stressor 1). The second stressor was the same, except that the temperature increase was $4^{\circ} \mathrm{C} / \mathrm{h}$ (stressor 2). For these stressors, fish remained at $26^{\circ} \mathrm{C}$ for about $10-15 \mathrm{~min}$. The third stressor was the same as the second, except that fish remained at $26^{\circ} \mathrm{C}$ until about $25 \%$ of the fish showed disequilibrium or died (stressor 3 ). The fourth stressor was also similar to the second, except that the maximum temperature was increased to $28^{\circ} \mathrm{C}$ (stressor 4). For all stressors, when heating was complete, the heaters were turned off and a $6-7^{\circ} \mathrm{C}$ inflow of water was used to cool water temperature down to $12^{\circ} \mathrm{C}$ in about $1 \mathrm{~h}$. After the stressor was completed, fish remained in their tanks at $12^{\circ} \mathrm{C}$ for a period of $5 \mathrm{~d}$. Miniature temperature loggers in each tank recorded water temperature every 5 min during application of the stressor and every hour thereafter. At each hour during application of the stressor and three times a day thereafter, we removed 
and tallied dead fish. In total, we conducted one complete trial for each stressor consisting of two replicate tanks each of treatment and control fish.

\section{Predation trials}

We conducted predation trials during two years, from July through September in 1998, and from June through July in 1999. In 1998, fall chinook salmon had an average length $(+\mathrm{SE})$ of $76.97 \pm 0.44 \mathrm{~mm}$ and a weight of $4.7 \pm 0.1 \mathrm{~g}(N=279)$; in 1999 , fish had a average length of $56.01 \pm 0.24 \mathrm{~mm}$ and a weight of $1.60 \pm 0.03 \mathrm{~g}(N=170)$. For a trial, four groups of about 15-20 fish were serially removed by netting from their stock tanks and placed into a $19 \mathrm{~L}$ bucket containing $50 \mathrm{mg} / \mathrm{L}$ tricaine methanesulfonate (MS-222) buffered with an equal amount of sodium bicarbonate. Two groups were designated as control fish and the other two groups were designated as treatment fish. We randomly selected and marked two groups (i.e., either control or treatment fish) by clipping the adipose fin with surgical scissors, whereas the other groups were sham marked by simply holding them out of the water for a sufficient period. After marking, 14 fish were placed in each of two control and treatment tanks as described in the mortality bioassays. Fish were held in these tanks for 2-3 d before being subjected to a thermal stressor.

On the morning of a predation trial, fish in the treatment tanks were subjected to one of two thermal stressors. Control fish and the predators always remained at $12^{\circ} \mathrm{C}$. In 1998, we conducted eight trials using stressor 1 and 12 trials using stressor 2. In 1999, we conducted 12 trials using stressor 1 . Immediately after fish were exposed to the thermal stressors (i.e., when water temperature in the treatment tanks was back at $12^{\circ} \mathrm{C}$ ), water level in all tanks was dropped to approximately $16 \mathrm{~L}$. Fish were then released into a 19 L bucket below the tanks by removing stand pipes and opening knife gates. 
Fourteen each of control and treatment fish were mixed in one bucket and poured into a predation tank. Smallmouth bass were allowed to consume juvenile salmon until $50 \%$ of the prey were eaten or $2 \mathrm{~h}$ had passed, whichever occurred first. Observations of fish behavior and estimates of the number of prey eaten were made from overhead using concealed platforms. At completion of the predation trial, the remaining prey were seined from the tanks and placed in a lethal dose $(200 \mathrm{mg} / \mathrm{L})$ of MS-222. Lengths and weights were recorded and fish were identified as treatment or control based on the presence of an adipose fin.

\section{Physiology experiment}

To assess some physiological responses of juvenile fall chinook salmon to a semiacute thermal stressor, we conducted one experiment in September of 1999. Fish used in this experiment had a mean $(+\mathrm{SE})$ length of $90.52 \pm 0.52 \mathrm{~mm}$ and a mean weight of 7.56 $\pm 0.14 \mathrm{~g}(N=126)$. Forty-five fish were stocked in each of two treatment tanks and two control tanks, as previously described. Fish were held in these tanks for $2 \mathrm{~d}$ prior to applying the stressor. At 0730 on the third day, fish in treatment tanks were subjected to stressor 1; control fish remained at ambient $\left(12^{\circ} \mathrm{C}\right)$ temperature during the experiment. Just prior to the stressor, we removed 4 fish from each tank (time $=0)$ and also removed a similar number of fish at the following times after the start: $3 \mathrm{~h}$, which was about the midway point of the temperature increase; $7 \mathrm{~h}$, which was the time of maximum temperature; $9 \mathrm{~h}$, which was $1 \mathrm{~h}$ after the rapid temperature decrease; and 24, 72, 168, and $336 \mathrm{~h}$. All sampled fish were placed in a lethal dose of MS-222, weighed and measured, and blood samples collected into ammonium-heparinized capillary tubes after severance of the caudal peduncle. Plasma was obtained by centrifugation and stored at - 
$80^{\circ} \mathrm{C}$ for future analysis. Plasma cortisol was measured using an enzyme-linked immunosorbent assay (ELISA) modified from procedures described by Munro and Stabenfeldt (1984). Plasma lactate and glucose were assayed using commercial kits (Sigma Diagnostics, St. Louis, MO) modified by us for use with microplates. Due to an insufficient amount of plasma, we were unable to assay all analytes from some fish. After collecting blood, we excised the liver, weighed it, wrapped it in aluminum foil and placed it in liquid nitrogen. These samples were transferred to an ultra-low freezer and stored at $-80^{\circ} \mathrm{C}$ for future analysis of hsp70 expression using an enzyme-linked immunosorbent assay (ELISA) as described by Forsyth et al. (1997).

\section{Data analysis}

Predation data were analyzed in a manner identical to that of Mesa (1994). We first subjected data to a heterogeneity $\Pi^{2}$ analysis to determine if the individual tests were homogenous (Sokal and Rohlf 1980). Chi-squared goodness-of-fit tests were then used on pooled data to determine if predation was random (i.e., 50:50) on treated versus control fish. Tests where less than $30 \%$ or more than $70 \%$ of the prey were eaten were excluded from the analysis for reasons discussed in Mesa and Warren (1997).

For the plasma constituents, we noted the presence of possible outliers in the form of abnormally high values. These extreme values occurred primarily in control fish, showed no discernable pattern, and never amounted to more than $15 \%$ of a total data set (range 1-14.5\%). To confirm these extreme values as outliers, we first constructed box and whisker plots for each data set within a sample period and noted which values were beyond the $95^{\text {th }}$ percentile. We then ranked the data within each sample period in descending order and used Dixon's statistic to test for the presence of outliers (Sokal and 
Rohlf 1980). Data points identified as outliers were removed from subsequent analyses. After outliers were removed, we calculated means and SE's for all plasma constituents at each sample period and plotted them over time. Within each sample period, we compared the means of treatment and control fish using two-sample $t$-tests for use with unequal variance. As an aside, we did analyze the plasma data with outliers included and noted only three minor differences (glucose at $3 \mathrm{~h}$ and cortisol at 0 and $72 \mathrm{~h}$ ) in the analyses with and without outliers. We present the analysis excluding outliers because it facilitated graphical representation of the data. There were no outliers in the hsp70 content of liver samples, and we expressed these data in relative units as a percentage of a positive control and analyzed the means as just described.

\section{Results}

\section{Direct mortality bioassays}

Only one control fish died during the trial exposing fish to stressor 1 , whereas only one treatment fish died during the trial assessing stressor 2. For fish exposed to stressor 3, it required about 2-2.5 h after the maximum temperature had been reached for about $25 \%$ of the fish to die. Thereafter, only one treatment fish died on the second day. For fish exposed to stressor 4, eight fish died in one treatment tank and five fish died in the other, all before the cool down phase of the stressor was complete. Thereafter, only one more treatment and one control fish died.

\section{Predation trials}

In 1998, we conducted a total of 8 trials using fish exposed to stressor 1 with an average of $48 \%$ of fish released eaten per trial. A total of 53 control and 54 treatment fish were eaten during the trials, which did not differ significantly from random (Table 1; 
$P=0.919$ ). Statistical power (to detect a $20 \%$ difference in predation rates) of the pooled $\Pi^{2}$ test was 0.66 . Duration of predation trials ranged from $5 \min$ to $2 \mathrm{~h}$, however the number of control and treatment fish consumed was independent of trial duration $\left(\Pi^{2}\right.$ test of independence, $P=0.501$ ). There were no significant differences in length or weight of control and treatment fish during the trials $(t$-tests, $P>0.05)$.

Also in 1998, we conducted a total of 12 trials using fish exposed to stressor 2 with an average of $47.5 \%$ of fish released eaten per trial. There were a total of 67 control and 82 treatment fish eaten, which again was not significantly different from random (Table 2; $P=0.217$ ). Statistical power of the pooled $\Pi^{2}$ test was 0.79 . Duration of predation trials ranged from $10 \mathrm{~min}$ to $2 \mathrm{~h}$, and again the number of control and treatment fish consumed was independent of trial duration $\left(\Pi^{2}, P=0.556\right)$. There was one trial with a significant ( $t$ test, $P<0.05$ ), but minor, difference in length of control and treatment fish.

In 1999, we conducted a total of 12 trials using fish exposed to stressor 1 with an average of $48.5 \%$ of fish released eaten per trial. There were a total of 78 control and 83 treatment fish eaten, which was not significantly different from random (Table 3; $P=$ 0.695). Statistical power of the pooled $\Pi^{2}$ test was 0.81 . Duration of predation trials ranged from $14 \mathrm{~min}$ to $2 \mathrm{~h}$, and again the number of control and treatment fish consumed was independent of trial duration $\left(\Pi^{2}, P=0.341\right)$. Although there were no significant differences in size of control and treatment fish used in these trials ( $t$-tests, $P>0.05)$, fish used in 1999 were significantly smaller than those used in 1998 ( $t$-tests, $P<0.05$; see length and weight data in the methods section).

\section{Physiology experiment}


Plasma cortisol levels in treatment fish were significantly higher than control fish prior to application of stressor 1 and also at $7 \mathrm{~h}$ after the start of the stressor, which was the time of maximum temperature (Fig. 2A). Thereafter, cortisol levels did not differ between treatment and control fish, except for a slight elevation in treatment fish at $72 \mathrm{~h}$. Plasma glucose levels increased gradually in treatment fish, peaking and becoming significantly higher than control fish only during the time of maximum temperature (Fig. 2B). Lactate levels in treatment fish showed about a 3-fold increase during application of the stressor and were significantly higher than control fish at 7 and $9 \mathrm{~h}$ (Fig. 2C). Plasma lactate concentrations did not differ between treatment and control fish at any sample period from $24 \mathrm{~h}$ on. Liver hsp70 content displayed a dramatic increase during the experiment that persisted for the entire two week period (Fig. 3). Levels of hsp70 in treatment fish were significantly higher than control fish at all sample periods except the first two.

\section{Discussion}

Our results indicate that juvenile fall chinook salmon exposed to our thermal stressors showed some stress-related physiological changes, a dramatic increase in levels of liver hsp70, but no increase in vulnerability to predation and little direct mortality. These thermal stressors, which were derived from field data and included a $14^{\circ} \mathrm{C}$ temperature increase over several hours followed by a rapid ( $1 \mathrm{~h})$ decrease to ambient temperature, are unique stressors that, to our knowledge, have not been previously studied. Most research on thermal stress in fishes has focused on two broad areas: (1) examining the effects of acute temperature "shocks", where fish acclimated to a certain temperature are subjected to dramatic changes in temperature usually within a few 
minutes (e.g., Coutant 1973; Wedemeyer 1973); and (2) examining the effects of different acclimation temperatures on selected measures of fish performance (e.g., Glova and McInerney 1977; Fuiman 1991; Cech et al. 1994). The wide variety of results produced by such studies indicates that they may not be useful for predicting the effects of semi-acute thermal stressors—-such as the types we used—on fish. Indeed, the influence of thermal stressors on fish performance seems dependent on numerous factors, including species, size and age, biology and physiology of the organism (e.g., eury- vs. stenothermal species), acclimation temperature, magnitude of temperature change, and tempering rate, among others.

Few juvenile fall chinook salmon died after exposure to our semi-acute thermal stressors up to $26^{\circ} \mathrm{C}$ (i.e., stressors 1 and 2), a temperature falling within the lethal range for this species (Brett 1952; Templeton and Coutant 1971). We attribute the lack of significant mortality in fish exposed to these two stressors to the short time fish remained at $26^{\circ} \mathrm{C}(10-15 \mathrm{~min})$ and the use of a very slow tempering rate. Tempering rate has been shown to influence the critical thermal maximum and survival of fish (Elliott and Elliott 1995; Clapp et al. 1997), and slow tempering is thought to at least prolong the time of death (Mather and Wahl 1989). Although our tempering rates were much slower than most reported in the literature, they are representative of what these fish would experience in the wild and probably helped prolong the time of death. However, our results indicate that if fish remain at $26^{\circ} \mathrm{C}$ (i.e., stressor 3) or are exposed to temperatures slightly above $26^{\circ} \mathrm{C}$ (i.e., stressor 4), mortality quickly ensues. Thus, for fish in the wild, the presence and use of cooler water refugia may be critical to their survival, a conclusion supported by the work of Mundahl (1990), who reported that survival of 14 species of 
fish in shrinking stream pools was dependent in part upon the use of shaded cooler refugia. Our results suggest that if fish in entrapment pools can survive periods of high temperatures until the pool re-floods with cool water, survival may be high since we showed little evidence of delayed mortality of fish exposed to our thermal stressors. However, because our research was conducted in laboratory tanks and for reasons discussed in our summary below, we suggest caution in extending our results to the complex natural environment.

Besides death, loss of equilibrium is a common response of fish to a sublethal exposure to lethal temperatures. In fact, only slight excursions of temperature above or below those normally encountered can elicit a sequence of behavioral and locomotory symptoms of sub-lethal heat injury (Logue et al. 1995). Coutant (1969) argued that equilibrium loss may be more important than death for fish subjected to thermal stressors because loss of equilibrium occurs sooner and elicits aberrant behavior that may make fish particularly vulnerable to predation. Indeed, loss of equilibrium and aberrant behavior are often mentioned as probable causes of the universally reported increased vulnerability to predation of fish subjected to acute thermal shocks (see references in the introduction). However, the semi-acute thermal stressors our fish received (i.e., stressors 1 and 2) did not sufficiently compromise the many behavioral and performance factors that affect the vulnerability of prey fish to predation (see Bams 1967; Coutant 1973; Mesa et al. 1994). Although we did note some aberrant behavior in fish as they approached the maximum temperature (e.g., erratic swimming or agitation), we saw no apparent behavioral differences in our treatment and control fish upon release to predators. All fish responded to predation pressure by forming schools soon after attacks 
had started. Thus, aside from species, age, or size differences, there appear to be differences in the nature and severity of acute thermal shocks and the type of thermal stressors we exposed our fish to, at least with regards to predator avoidance ability. Our results suggest that juvenile fall chinook salmon were capable of avoiding predators soon after experiencing a thermal stressor of the type we used, a conclusion also noted in studies subjecting juvenile salmonids to physical stressors (Olla and Davis 1989; Mesa 1994).

Notably, size of prey did not influence the outcome of our predation experiments. In 1998, the size of fish we used was larger than that typically seen in fall chinook salmon rearing in the Hanford Reach. We purposely grew our fish to a size almost twice that of fish in the Hanford Reach because very small fish would be difficult to: (1) remove from our predation tanks; (2) see from overhead during a test; and (3) bleed during preliminary physiological experiments. Also, we had limited tank space to grow fish of different sizes. Because size is known to influence aspects of the thermal biology (Baroudy and Elliott 1994), stress physiology (Barton 1997), and predator avoidance ability (Fuiman and Magurran 1994) of fishes, we used prey in 1999 that were significantly smaller than those used in 1998, yet obtained similar results. Although the smaller fish were somewhat more difficult to work with, we encountered no serious limitations to our protocols. We surmise that the well documented advantages of schooling behavior in countering predators (Pitcher 1986; Magurran 1990) benefited both sizes of prey, thus leading to no size-related influence in our predation tests.

The physiological factors we examined indicated that exposure of our fall chinook salmon to a semi-acute temperature increase was stressful. Except for hsp70 expression, 
which we will discuss below, the other factors we assessed (plasma cortisol, glucose, and lactate) all increased during the thermal warming, reached maximal values at the time of maximal temperature, and returned to levels similar to initial values by $24 \mathrm{~h}$. Some studies have reported similar responses in other species exposed to thermal stress. For example, hypercortisolemia or hyperglycemia (or both) have been shown in cutthroat trout (O. clarki), steelhead (O. mykiss), coho salmon (O. kisutch), and Tilapia aurea exposed to acute temperature shocks (Wedemeyer 1973; Strange et al. 1977; Kindle and Whitmore 1986), in coho salmon exposed to a fluctuating temperature regime of

\section{$6.5-20^{\circ} \mathrm{C}$ (Thomas et al. 1986), and in Tilapia aurea and striped bass (Morone} saxitalis) acclimated to temperatures outside their preferred range (Kindle and Whitmore 1986; Davis and Parker 1990). In contrast, some of the same or other studies have shown little or no response of plasma cortisol and glucose in fish to temperature stressors (e.g., Strange et al. 1977; Carmichael et al. 1984; Thomas et al. 1986). Thus, the physiological responses of fish to thermal stressors varies widely and seems dependent primarily on species and type of stressor used. If increases in plasma cortisol and glucose do occur in response to thermal stress, they probably serve to mobilize energy stores for essential reactions (e.g., ATP production) and help maintain osmoregulatory function, among other things.

Plasma lactate concentrations were higher in treatment fish relative to controls, significantly so at the time of maximum temperature and $1 \mathrm{~h}$ after the cool down had occurred. We are unaware of other studies reporting changes in plasma lactate concentrations in fish subjected to thermal stressors. Such elevations in plasma lactate indicate some degree of anaerobic metabolism was occurring in fish exposed to the 
thermal stressor and are probably due to a combination of factors. During temperature increases in ectotherms, blood $\mathrm{pH}$ decreases and $\mathrm{PCO}_{2}$ increases (Crawshaw 1979). At high temperatures and low $\mathrm{pH}$, hemoglobin has a low affinity for oxygen (SchmidtNielsen 1991) and there may be decreases in $\mathrm{PaO}_{2}$ (Soncini and Glass 1997), thus leading to problems with oxygen delivery to the tissues. This, coupled with the increased metabolic demands and hyperactivity of our fish and the low oxygen carrying capacity of water at high temperatures, probably contributed to their lactacidosis. Such changes in the acid-base balance of fish subjected to temperature change probably contribute substantially to mortality as lethal temperatures are approached.

Exposure of juvenile fall chinook salmon elicited a dramatic response in liver hsp70 content. Significant hsp70 expression was first apparent at $7 \mathrm{~h}$, which was the time of maximum temperature. Thereafter, when water temperature was $12^{\circ} \mathrm{C}$, hsp 70 levels peaked at $24 \mathrm{~h}$ and remained elevated above control values for the entire two week period. The magnitude of maximum change represented a more than 25 -fold increase over control levels. Mazur (1996) also reported that hsp70 levels in the gills of cutthroat trout were still elevated up to 3 weeks after fish were exposed to a $2 \mathrm{~h}, 15^{\circ} \mathrm{C}$ heat shock $\left(7.4-22.4^{\circ} \mathrm{C}\right)$. Heat shock proteins are a group of proteins synthesized by cells in response to heat and many other types of stressors, such as exposure to contaminants (Lindquist 1986; Lindquist and Craig 1988; Iwama et al. 1998). The constitutive and inducible expression of hsps is perhaps the most highly conserved genetic system known, existing in all organisms from bacteria to plants to animals. The functions of hsps in response to stress help to maintain cellular homeostasis and include protein assembly, correct folding and translocation, and regulating hormone-receptor interactions (Iwama et 
al. 1998). The hsps prevent the aggregation and facilitate the renaturation of heatdamaged proteins following a heat shock, thus they play a vital role in thermotolerance (Tomanek and Somero 1999). In short, the hsp70 response of our fish probably provided cellular protection and enhanced survival against a thermal insult that approached the upper lethal temperature limits for this species.

In summary, we have shown that exposure of juvenile fall chinook salmon to naturally occurring semi-acute thermal stressors elicited some acute physiological stress responses and a significant and prolonged elevation of liver hsp70 content, but did not lead to substantial mortality or increased vulnerability to predation. Although our results may suggest that such stressors pose no serious threat to these fish, there are several factors to consider in their interpretation. First, we tested only a few of potentially myriad thermal stressors experienced by fish in the Hanford Reach, and perhaps elsewhere. Several factors associated with this type of thermal stressor, including the rate of temperature changes, the initial and maximum temperatures, and the time spent by fish at the maximum temperature, could affect the responses of fish. For example, the rate of temperature increase is known to affect the critical thermal maxima of fish (e.g., Elliott and Elliott 1995). Second, we exposed our fish to only a single thermal stressor and are concerned, particularly because of the prolonged hsp response, about the consequences of exposure of fish to multiple, cumulative stressors. Such a scenario is highly probable for our fish in the wild, and exposure of fish to multiple stressors in nature is common and can have cumulative, relatively severe physiological and behavioral effects (Barton et al. 1986; Maule et al. 1988; Sigismondi and Weber 1988; Mesa 1994). Finally, there are other possible effects of thermal stressors on fish that we did not address in this study. A 
recent and relevant example is a report of a high incidence (84\%) of phenotypic female chinook salmon in the Hanford Reach bearing a genetic marker characteristic of the male sex (Nagler et al. 2001). One possible reason for this sex reversal in males, which could lead to an abundance of an abnormal YY genotype in the wild and alter sex ratios significantly, is exposure of developing embryos to elevated temperatures (Nagler et al. 2001). Thus, although temperature is one of the most widely studied environmental factors affecting fish, considerations here indicate that our understanding of the effects of thermal stressors on fish remains incomplete.

\section{References}

Bailey, J., Sephton, D., and Driedzic, W.R. 1991. Impact of an acute temperature change on performance and metabolism of pickerel (Esox niger) and eel (Anguilla rostrata) hearts. Phys. Zool. 64:697-716.

Bams, R.A. 1967. Differences in performance of naturally and artificially propagated sockeye salmon migrant fry, as measured with swimming and predation tests. J. Fish. Res. Board Can. 24:1117-1153.

Baroudy, E., and Elliott, J.M. 1994. The critical thermal limits for juvenile Arctic charr Salvelinus alpinus. J. Fish Biol. 45:1041-1053.

Barton, B.A. 1997. Stress in finfish: past, present, and future-a historical perspective. Pages 1-33 in Iwama, G.K, Pickering, A.D., Sumpter, J.P., and Schreck, C.B., editors. Fish Stress and Health in Aquaculture. Cambridge University Press, Cambridge, United Kingdom.

Barton, B.A., Schreck, C.B., and Sigismondi, L.A. 1986. Multiple acute disturbances evoke cumulative physiological stress responses in juvenile chinook salmon. 
Appendix F

Trans. Am. Fish. Soc. 115: 245-251.

Brett, J.R. 1952. Temperature tolerance in young Pacific salmon, genus Oncorhynchus. J. Fish. Res. Bd. Can. 9:265-323.

Carmichael, G.J., Tomasso, J.R., Simco, B.A., and Davis, K.B. 1984. Confinement and water quality-induced stress in largemouth bass. Trans. Am. Fish. Soc. 113:767777.

Cech, J.J. Jr., Castleberry, D.T., and Hopkins, T.E. 1994 Temperature and $\mathrm{CO}_{2}$ effects on blood $\mathrm{O}_{2}$ equilibria in northern squawfish, Ptychocheilus oregonensis. Can. J. Fish. Aquat. Sci. 51:13-19.

Clapp, D.F., Bhagwat, Y., and Wahl, D.H. 1997. The effect of thermal stress on walleye fry and fingerling mortality. N. Am. J. Fish. Manage. 17:429-437.

Coutant, C.C. 1969. Temperature, reproduction and behavior. Chesapeake Sci. 10:261274.

Coutant, C.C. 1973. Effect of thermal shock on vulnerability of juvenile salmonids to predation. J. Fish. Res. Board Can. 30:965-973.

Crawshaw, L.I. 1977. Physiological and behavioral reactions of fishes to temperature change. J. Fish. Res. Board Can. 34:730-734.

Crawshaw, L.I. 1979. Responses to rapid temperature change in vertebrate ectotherms. Amer. Zool. 19:225-237.

Davis, K.B., and Parker, N.C. 1990. Physiological stress in striped bass: effect of acclimation temperature. Aquaculture. 91:349-358.

Deacutis, C.F. 1978. Effect of thermal shock on predator avoidance by larvae of two fish species. Trans. Am. Fish. Soc. 107:632-635. 
Elliott, J.M., and Elliott, J.A. 1995. The effect of rate of temperature increase on the critical thermal maximum for parr of Atlantic salmon and brown trout. J. Fish Biol. 47:917-919.

Forsyth, R.B., Candido, E.P.M., Babich, S.L., and Iwama, G.K. 1997. Stress protein expression in coho salmon with bacterial kidney disease. J. Aquat. Anim. Health 9:18-25.

Fuiman, L.A. 1991 Influence of temperature on evasive responses of Atlantic herring larvae attacked by yearling herring, Clupea harengus L. J. Fish Bio. 39:93-102.

Fuiman, L.A., and Magurran, A.E. 1994. Development of predator defences in fishes. Rev. in Fish Biol. and Fish. 4:145-183.

Glova, G.J., and McInerney, J.E. 1977 Critical swimming speeds of coho salmon (Oncorhynchus kisutch) fry to smolt stages in relation to salinity and temperature. J. Fish. Res. Board Can. 34: 151-154.

Iwama, G.K., Thomas, P.T., Forsyth, R.B., and Vijayan, M. M. 1998. Heat shock protein expression in fish. Rev. Fish Bio. Fish. 8:35-56.

Kindle, K.R., and Whitmore, D.H. 1986. Biochemical indicators of thermal stress in Tilapia aurea (Steindachner). J. Fish Biol. 29:243-255.

Lindquist, S. 1986. The heat shock response. Ann. Rev. Biochem. 55:1151-1191. Lindquist, S., and Craig, E.A. 1988. The heat-shock proteins. Annu. Rev. Genet. 22:631-677.

Logue, J. Tiku, P, and Cossins, A.R. 1995. Heat injury and resistance adaptation in fish. J. Therm. Biol. 20:191-197.

Magurran, A.E. 1990. The adaptive significance of schooling as an anti-predator 
defence in fish. Annales. Zoologici. 27:51-66.

Mather, M.E., and Wahl, D.H. 1989. Comparative mortality of three esocids due to stocking stressors. Can. J. Fish. Aquat. Sci. 46:00214-217.

Maule, A.G., Schreck, C.B., Bradford, C.S., and Barton, B.A. 1988 Physiological effects of collecting and transporting emigrating juvenile chinook salmon past dams on the Columbia River. Trans. Am. Fish. Soc. 117:245-261.

Mazur, C.F. The heat shock protein response and physiological stress in aquatic organisms. Doctoral thesis, University of British Columbia.

Mesa, M.G. 1994. Effects of multiple acute disturbances on the predator avoidance, physiology, and behavior of juvenile chinook salmon. Trans. Am. Fish. Soc. 123:786-793.

Mesa, M.G., Poe, T.P., Gadomski, D.M., and Petersen, J.H. 1994. Are all prey created equal? A review and synthesis of differential predation on prey in substandard condition. J. Fish Biol. 45 (Supplement A):81-96.

Mesa, M.G., and Warren, J.J. 1997. Predator avoidance ability of juvenile chinook salmon (Oncorhynchus tshawytscha) subjected to sublethal exposures of gassupersaturated water. Can. J. Fish. Aquat. Sci. 54:757-764.

Mundahl, N.D. 1990. Heat death of fish in shrinking stream pools. Am. Midl. Natt. 123:40-46.

Munro, C., and Stabenfeldt, G. 1984. Development of a microtitre plate enzyme immunoassay for the determination of progesterone. J. Endocrinol. 101:41-49. 
Nagler, J.J., Bouma, J., Thorgaard, G.H., and Dauble, D.D. 2001. High incidence of a male-specific marker in phenotypic female chinook salmon from the Columbia river. Environ. Health Perspect. 109:67-69.

Olla, B.L., and Davis, M.W. 1989. The role of learning and stress in predator avoidance of hatchery-reared coho salmon (Oncorhynchus kisutch) juveniles. Aquaculture. 76:209-214.

Phinney, L.A. 1974. Further observations on juvenile salmon stranding in the Skagit River, March 1973. Washington Department of Fisheries.

Pitcher, T.J. 1986. Functions of shoaling behavior in teleosts. In The behavior of teleost fishes. Edited by T.J. Pitcher. Johns Hopkins University Press, Baltimore, Maryland. pp. 294-337.

Sanders, B.M. 1993. Stress proteins in aquatic organisms: an environmental perspective. Crit. Rev. Toxicol. 23:49-75.

Schmidt-Nielsen, K. 1991. Animal physiology: adaptation and environment. Cambridge University Press, Cambridge, United Kingdom.

Sigismondi, L.A., and Weber, L.J. 1988. Changes in avoidance response time of juvenile chinook salomon exposed to multiple acute handling stresses. Trans. Am. Fish. Soc. 117:196-201.

Sokal, R.R., and Rohlf, F.J. 1981. Biometry. W.H. Freeman and Co., New York.

Soncini, R., and Glass, M.L. 1997. The effects of temperature and hyperoxia on arterial $\mathrm{PO}_{2}$ and acid-base status in Piaractus mesopotamicus. J. Fish Biol. 51:225-233.

Strange, R.J., Schreck, C.B., and Golden, J.T. 1977. Corticoid stress responses to handling and temperature in salmonids. Trans. Am. Fish. Soc. 106:213-218. 
Sylvester, J.R. 1972. Effect of thermal stress on predator avoidance in sockeye salmon. J. Fish. Res. Board Can. 29:601-603.

Templeton, W.L., and Coutant, C.C. 1971. Studies on the biological effects of thermal discharges from nuclear reactors to the Columbia River at Hanford. Pages 591614 in Environmental Aspects of Nuclear Power Stations. International Atomic Energy Agency, Vienna.

Thomas, R.E., Gharrett, J.A., Carls, M.G., Rice, S.D., Moles, A., and Korn, S. 1986. Effects of fluctuating temperature on mortality, stress, and energy reserves of juvenile coho salmon. Trans. Am. Fish. Soc. 115:52-59.

Thompson, J.S. 1970. Skagit River fry mortality study, March 1969. Washington Department of Fisheries.

Tipping, J., Buckley, P., and Danielson, J. 1978. Cowlitz River steelhead spawning and fry stranding study, 1977-78. Progress Report, Washington Department of Game. Tomanek, L., and Somero, G.N. 1999. Evolutionary and acclimation-induced variation in the heat-shock responses of congeneric marine smails (Genus Tegula) from different thermal habitats: implications for limits of thermotolerance and biogeography. J. Exp. Bio. 202: 2925-2936.

Wedemeyer, G. 1973. Some physiological aspects of sublethal heat stress in the juvenile steelhead trout (Salmo gairdneri) and coho salmon (Oncorhynchus kisutch). J. Fish. Res. Board Can. 30:831-834.

Woodin, R. 1984. Evaluation of salmon fry stranding induced by fluctuating hydroelectric discharge in the Skagit River, 1980-83. Technical Report No. 83, Washington Department of Fisheries. 
Yocom, T.G., and Edsall, T.A. 1974. Effect of acclimation temperature and heat shock on vulnerability of fry of lake whitefish (Coregonus clupeaformis) to predation. J. Fish. Res. Board Can. 31:1503-1506. 
Table 1. Predation by smallmouth bass on juvenile fall chinook salmon acclimated to $12^{\circ} \mathrm{C}$, subjected to a heating of $2 \mathrm{EC} / \mathrm{h}$ up to $26 \mathrm{EC}$, and a temperature decrease within $1 \mathrm{~h}$ to 12EC (i.e, stressor 1 in Fig. 1). Data are from experiments conducted in 1998.

\begin{tabular}{|c|c|c|c|c|c|}
\hline \multirow{2}{*}{$\begin{array}{l}\text { Replicate or } \\
\text { statistic }\end{array}$} & \multicolumn{2}{|c|}{ Number eaten } & \multirow{2}{*}{$\begin{array}{c}\text { Percent } \\
\text { eaten }\end{array}$} & \multicolumn{2}{|c|}{ Statistics } \\
\hline & Control & Treatment & & $\mathrm{df}$ & $\Pi^{2}$ \\
\hline 1 & 7 & 5 & 43 & 1 & 0.333 \\
\hline 2 & 4 & 6 & 36 & 1 & 0.400 \\
\hline 3 & 11 & 8 & 68 & 1 & 0.474 \\
\hline 4 & 4 & 7 & 46 & 1 & 0.818 \\
\hline 5 & 10 & 5 & 54 & 1 & 1.667 \\
\hline 6 & 6 & 8 & 50 & 1 & 0.286 \\
\hline 7 & 5 & 8 & 46 & 1 & 0.692 \\
\hline 8 & 6 & 7 & 46 & 1 & 0.077 \\
\hline Total & 53 & 54 & & 8 & 4.747 \\
\hline Pooled & & & & 1 & 0.009 \\
\hline Heterogeneity & & & & 7 & 4.738 \\
\hline
\end{tabular}

Note: No predation rates differed significantly $(P \# 0.10)$ from random $(50: 50$, treatment:control). 
Table 2. Predation by smallmouth bass on juvenile fall chinook salmon acclimated to $12 \mathrm{EC}$, subjected to a heating of $4 \mathrm{EC} / \mathrm{h}$ up to $26 \mathrm{EC}$, and a temperature decrease within $1 \mathrm{~h}$ to 12EC (i.e., stressor 2 in Fig. 1). Data are from experiments conducted in 1998.

\begin{tabular}{|c|c|c|c|c|c|}
\hline \multirow{2}{*}{$\begin{array}{l}\text { Replicate or } \\
\text { statistic }\end{array}$} & \multicolumn{2}{|c|}{ Number eaten } & \multirow{2}{*}{$\begin{array}{c}\text { Percent } \\
\text { eaten }\end{array}$} & \multicolumn{2}{|c|}{ Statistics } \\
\hline & Control & $\overline{\text { Treatment }}$ & & $\mathrm{df}$ & $\Pi^{2}$ \\
\hline 1 & 5 & 4 & 56 & 1 & 0.111 \\
\hline 2 & 5 & 9 & 50 & 1 & 1.143 \\
\hline 3 & 8 & 6 & 52 & 1 & 0.286 \\
\hline 4 & 8 & 7 & 53 & 1 & 0.067 \\
\hline 5 & 4 & 5 & 32 & 1 & 0.111 \\
\hline 6 & 5 & 8 & 46 & 1 & 0.692 \\
\hline 7 & 7 & 10 & 65 & 1 & 0.529 \\
\hline 8 & 5 & 9 & 50 & 1 & 1.143 \\
\hline 9 & 7 & 4 & 39 & 1 & 0.818 \\
\hline 10 & 6 & 8 & 58 & 1 & 0.286 \\
\hline 11 & 3 & 6 & 32 & 1 & 1.000 \\
\hline 12 & 4 & 6 & 38 & 1 & 0.400 \\
\hline Total & 67 & 82 & & 12 & 6.586 \\
\hline Pooled & & & & 1 & 1.510 \\
\hline Heterogeneity & & & & 11 & 5.076 \\
\hline
\end{tabular}

Note: No predation rates differed significantly $(P \# 0.10)$ from random $(50: 50$, treatment:control). 
Table 3. Predation by smallmouth bass on juvenile fall chinook salmon acclimated to $12 \mathrm{EC}$, subjected to a heating of $2 \mathrm{EC} / \mathrm{h}$ up to $26 \mathrm{EC}$, and temperature decrease within $1 \mathrm{~h}$ to 12EC (i.e., stressor 1 in Fig. 1). Data are from experiments conducted in 1999.

\begin{tabular}{|c|c|c|c|c|c|}
\hline \multirow{2}{*}{$\begin{array}{l}\text { Replicate or } \\
\text { statistic }\end{array}$} & \multicolumn{2}{|c|}{ Number eaten } & \multirow{2}{*}{$\begin{array}{c}\text { Percent } \\
\text { eaten }\end{array}$} & \multicolumn{2}{|c|}{ Statistics } \\
\hline & Control & $\overline{\text { Treatment }}$ & & $\overline{\mathrm{df}}$ & $\Pi^{2}$ \\
\hline 1 & 5 & 6 & 39 & 1 & 0.091 \\
\hline 2 & 2 & 7 & 32 & 1 & 2.778 \\
\hline 3 & 12 & 8 & 71 & 1 & 0.800 \\
\hline 4 & 7 & 8 & 54 & 1 & 0.067 \\
\hline 5 & 4 & 8 & 50 & 1 & 1.333 \\
\hline 6 & 4 & 6 & 36 & 1 & 0.400 \\
\hline 7 & 7 & 8 & 54 & 1 & 0.067 \\
\hline 8 & 6 & 5 & 39 & 1 & 0.091 \\
\hline 9 & 8 & 8 & 57 & 1 & 0.000 \\
\hline 10 & 9 & 5 & 50 & 1 & 1.143 \\
\hline 11 & 6 & 8 & 50 & 1 & 0.286 \\
\hline 12 & 8 & 6 & 50 & 1 & 0.286 \\
\hline Total & 78 & 83 & & 12 & 7.341 \\
\hline Pooled & & & & 1 & 0.155 \\
\hline Heterogeneity & & & & 11 & 7.186 \\
\hline
\end{tabular}

Note: No predation rates differed significantly $(P \# 0.10)$ from random $(50: 50$, treatment:control). 


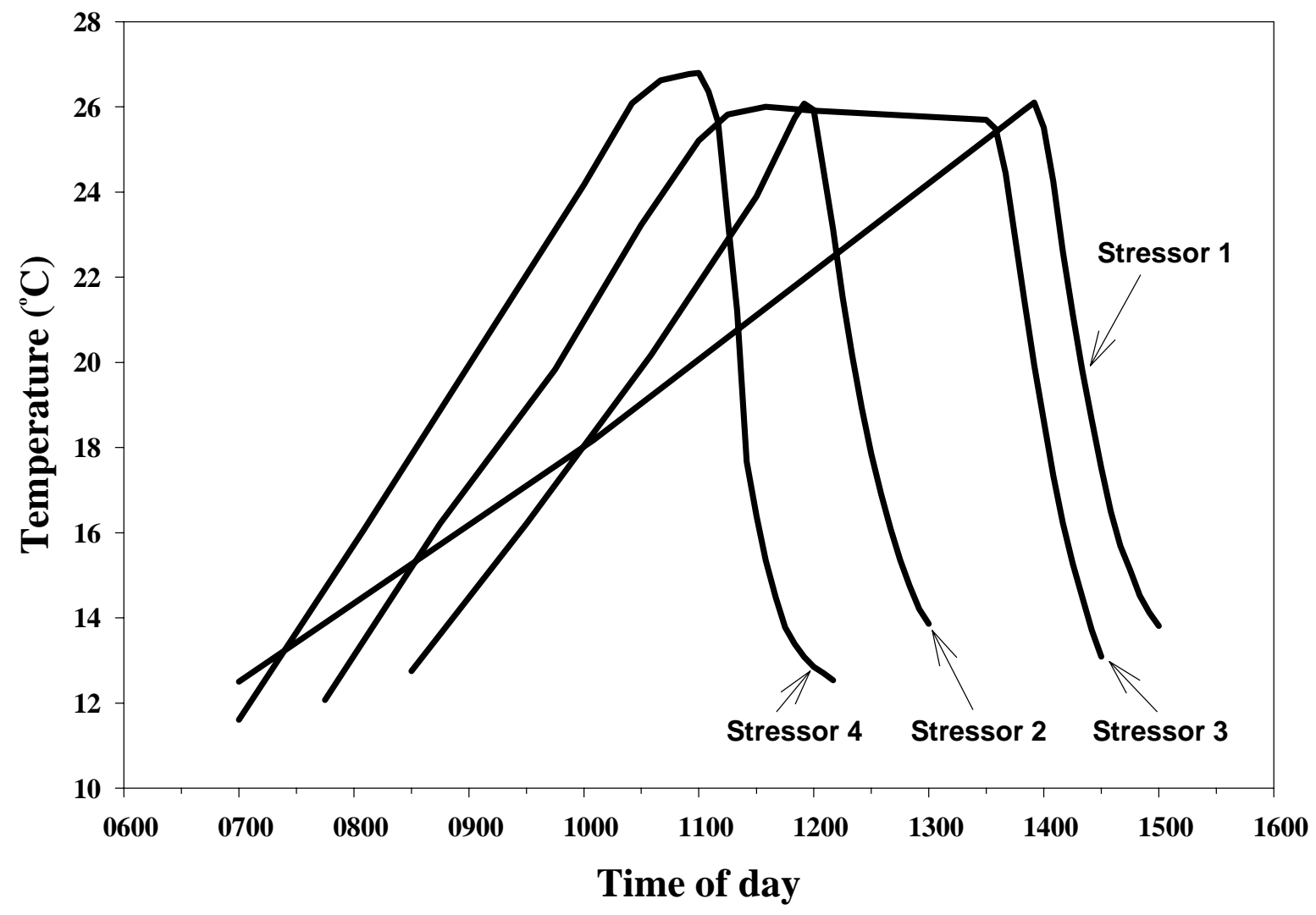

Fig. 1. Semi-acute thermal stressors used in our laboratory experiments. Curves were spline-fit to thermograph data from several tanks during our study. Starting times for the curves were staggered to facilitate graphical representation. See methods for written descriptions of the stressors. 

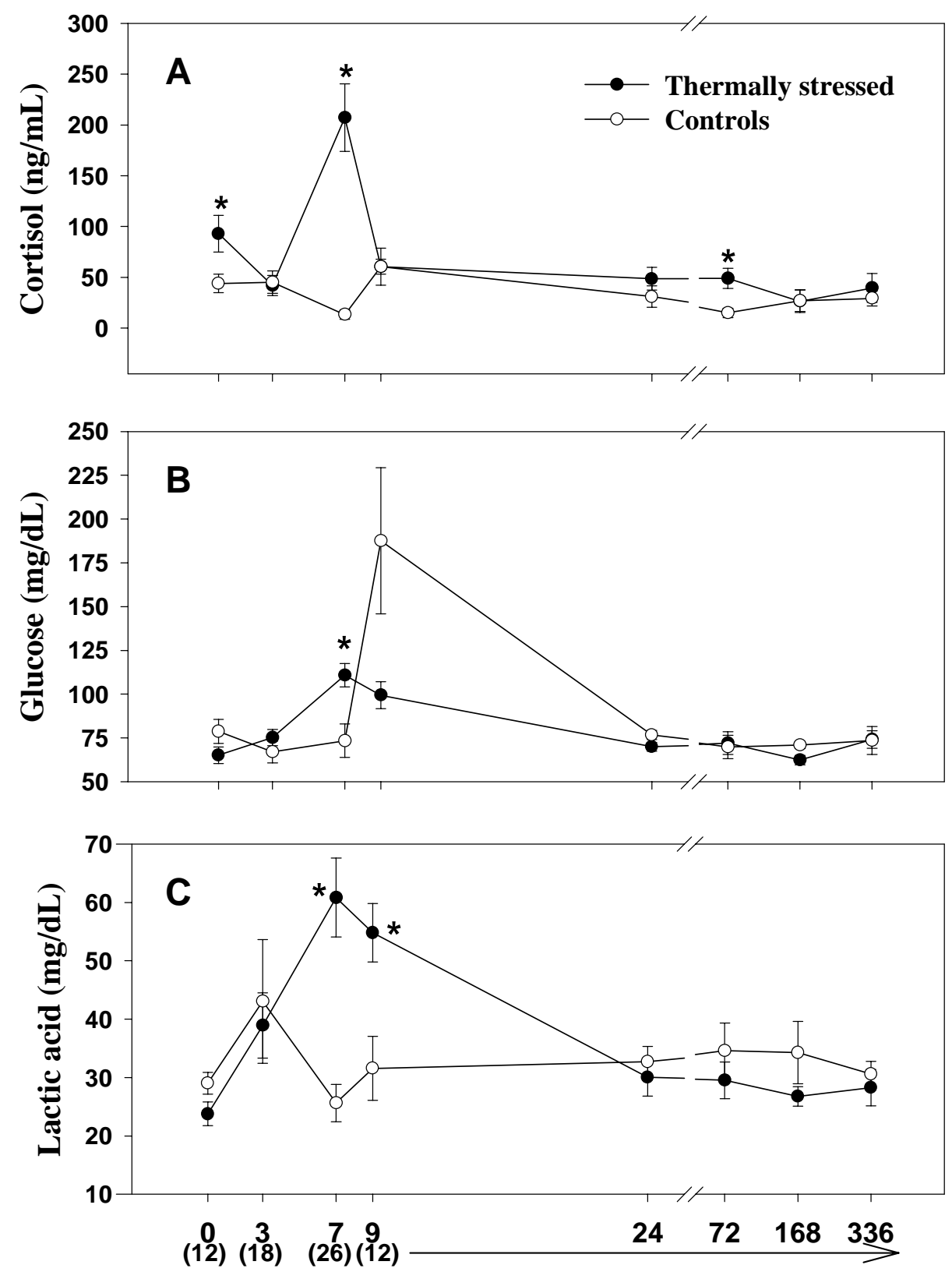

Hour (water temperature, ${ }^{\circ} \mathrm{C}$ ) after start of stressor

Fig. 2. Average ( \pm SE) plasma (A) cortisol, (B) glucose, and (C) lactate concentrations for fish at selected time intervals after they had been exposed to thermal stressor 1 and for unstressed controls. An asterisk denotes a significant $(P<0.05)$ difference between treatment and control fish at that time interval. 
Appendix F

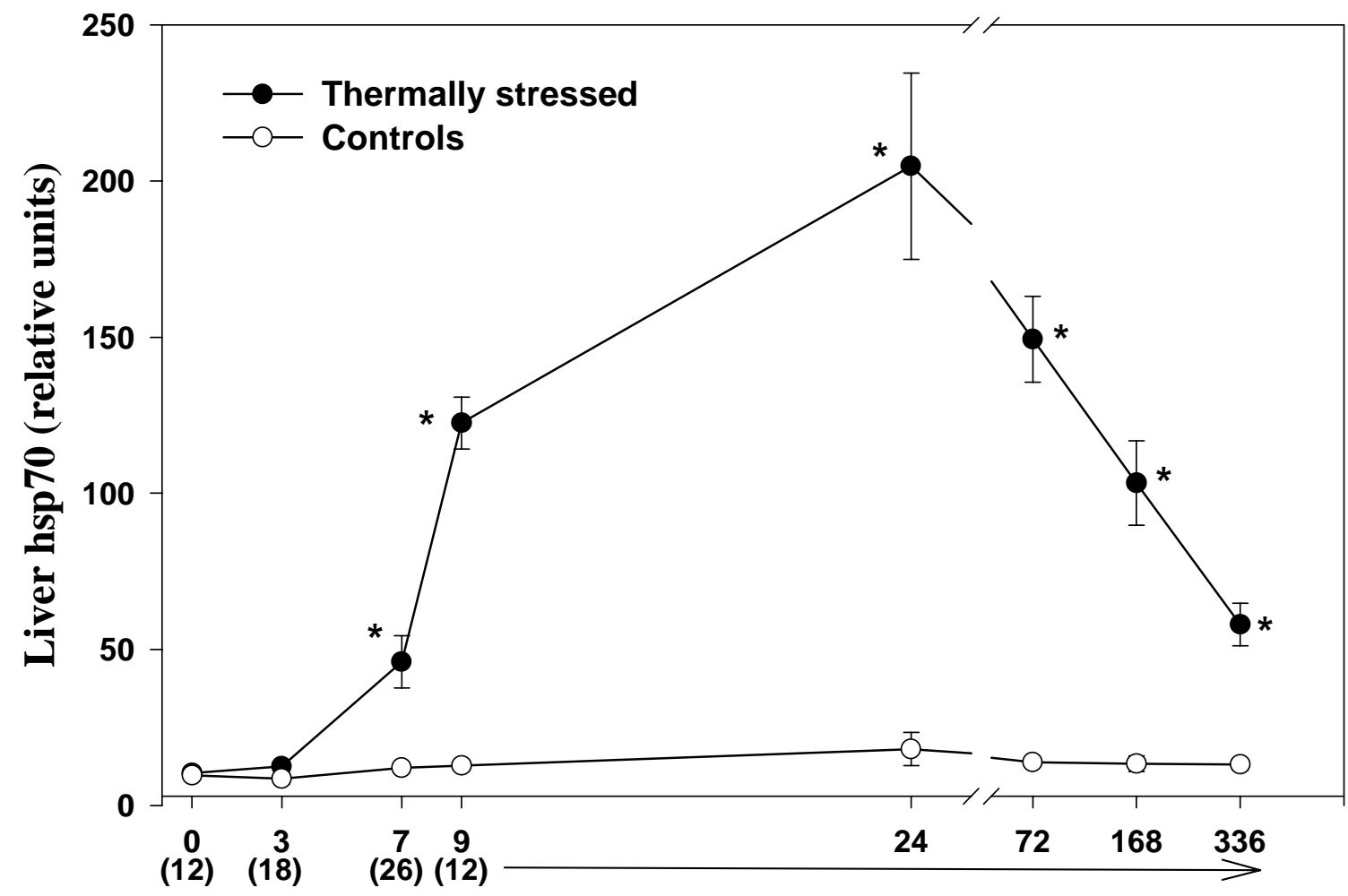

Hour (water temperature, ${ }^{\circ} \mathrm{C}$ ) after start of stressor

Fig. 3. Average $( \pm \mathrm{SE})$ liver hsp70 content for fish at selected time intervals after they had been exposed to thermal stressor 1 and for unstressed controls. An asterisk denotes a significant $(P<0.05)$ difference between treatment and control fish at that time interval. 